А.Г. ЧЕРКАШИНА, А.Н. ВАААИМИРОВ, Н.H. НОВИКОВА

\title{
Состояние
}

и перспективы развития традиционных отраслей в РС (Я)

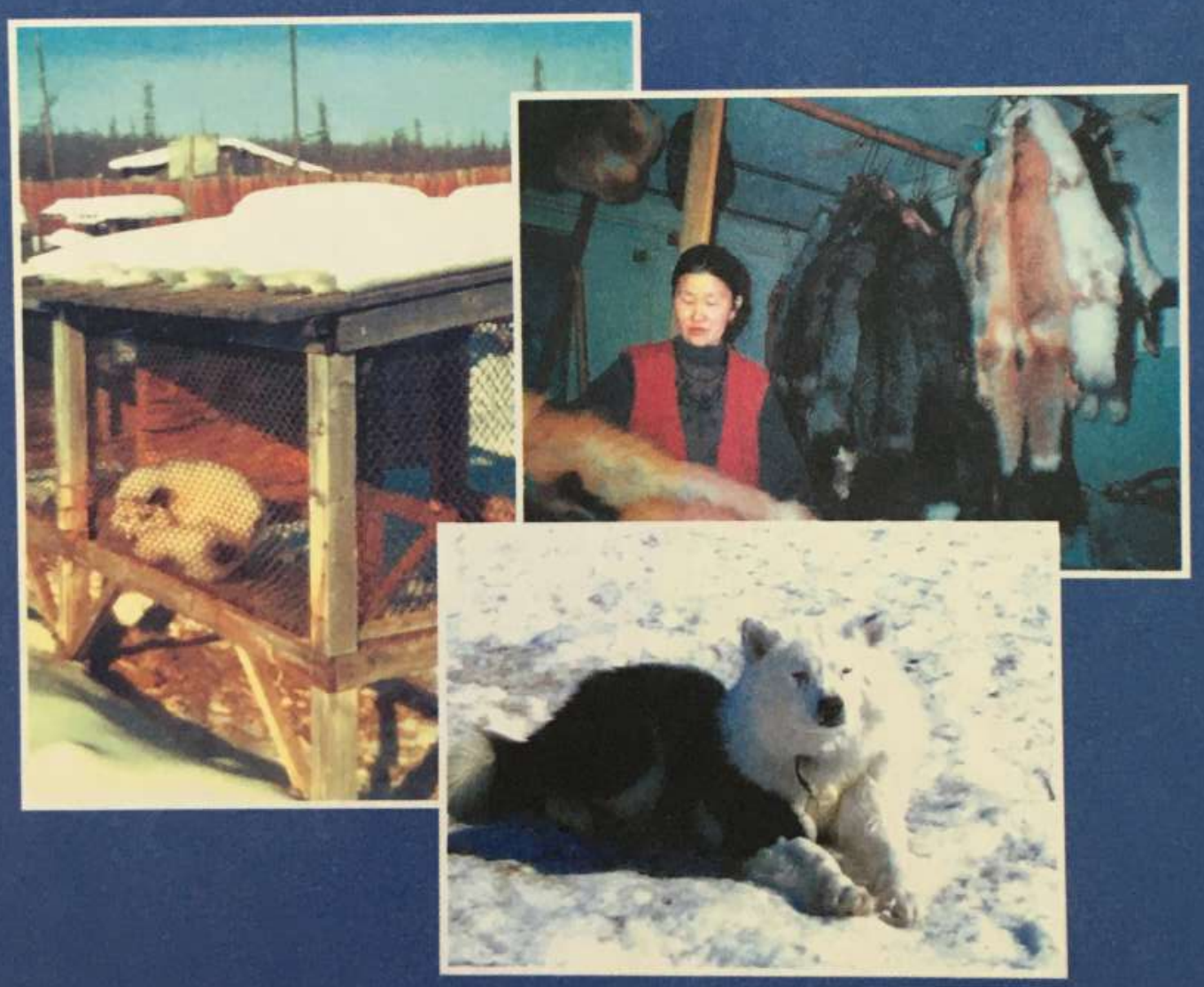


Министерство сельского хозяйства Российской Федерации Департамент научно-технологической политики и образования Федеральное государственное образовательное учреждение высшего профессионального образования

Якутская государственная сельскохозяйственная академия

ЧЕРКАШИНА А.Г., ВЛАДИМИРОВ Л.Н., НОВИКОВА Н.Н.

\section{Состояние и перспективы развития традиционных отраслей в РС (Я)}

Рекомендовано Учебно-методическим объединением высших учебных заведений Российской Федерации по образованию в области зоотехнии и ветеринарии для студентов высших учебных заведений в качестве учебного пособия по специальности 110400 Зоотехния 
Рецензенты:

ОГЛАВЛЕНИЕ

Введение

Глава 1. Теоретические предпосылки к использованию

биологически активных веществ в пушном звероводстве Якутии......

1.1. Х Характеристика хозяйственно-полезных признаков серебристочерных лисиц

1.2. Причины недоразвития молодняка пушных зверей

1.3. Использование биологически активных веществ в кормлении пушных зверей

1.3.1. Механизм действия парааминобензойной кислоты (ПАБК)

1.3.2. Механизм действия янтарной кислоты (ЯК)

1.3.3. Механизм действия сукцината хитозана (CX)

1.3.4. Механизм действия цеолита

Глава 2.Материал и методика исследований

Глава 3. Состояние и перспективы клеточного звероводства в РС (Я)......

3.1. Современное состояние клеточного звероводства в РС (Я).

3.2. Коррекция роста и развития гипотрофичного молодняка лисиц с помощью парааминобензойной кислоты, сукцината хитозана, янтарной кислоты и цеолита.

3.2.1. Влияние парааминобензойной кислоты на рост и развитие гипотрофичного молодняка лисиц. ...

3.2.2. Влияние сукцината хитозана на рост и развитие гипотрофичного молодняка лисиц

3.2.3. Влияние янтарной кислоты на рост и развитие гипотрофичного молодняка лисиц

3.2.4. Влияние цеолита на рост и развитие гипотрофичного молодняка лисиц

3.2.5. Результаты дисперсионного анализа оптимальных доз биологически 
активных веществ (парааминобензойной кислоты, сукцината хитозана, янтарной кислоты и цеолита).

3.3. Определение оптимально эффективного биологически активного препарата для стимуляции роста и развития гипотрофичного молодняка лисиц.

3.4.Разведение норок в Якутии в 60-е годы XX века....

3.5.Перспективы норководства в РС (Я)

Глава 4. Перспективы развития охотничьего собаководства в РС (Я)......

4.1.Современное состояние собаководства в Якутии.

4.2. Советы по разведению лаек

4.3.Теоретические предпосылки к разведению лаек

4.4.Натаскивание и оценка охотничьих собак

Выводы

Литература 


\section{Введение}

Крайне суровые природно-климатические и хозяйственноэкономические условия Севера отражаются на организме местных пород животных. Так при содержании клеточных пушных зверей круглый год под открытым небом в условиях резко континентального климата, когда летом температура воздуха достигает плюс 35 град, а зимнее время минус 55 градусов по Цельсию, безусловно, эти условия являются лимитирующими факторами для роста и развития, повышения продуктивности, воспроизводства местных пород. Породы животных в мире не подвергаются такому прессингу внешних факторов в период онтогенеза, как породы сельскохозяйственных животных в условиях Республики Саха (Якутия).

Следовательно, в породообразовании в северном регионе нужны меры по смягчению экстремальных факторов жизни пород путем организации надлежащего ухода и питания их в критические сезоны года. Исходя из этого задачами селекционеров в улучшении и создании пород в звероводстве Республики Саха (Якутия) являются: совершенствование качества опушения, окраса, увеличение размера, улучшение продуктивных качеств зверей для повышения конкурентоспособности продукции на рынке сбыта, выведение различных цветовых форм лисиц, песца, приспособленных к местным кормовым и климатическим условиям (Чугунов А.В.,1998).

Основная цель пушного звероводства в Якутии - увеличение пушной продукции для пошива теплой одежды в суровых климатических условиях. Важно и то, что звероводство имеет социальное значение, особенно для северных улусов, где оно призвано способствовать повышению занятости и материальной обеспеченности членов семей охотников, рыбаков и оленеводов.

В Российской Федерации принята концепция развития звероводства до 2005-2010 года, базирующаяся на коренном улучшении кормовой базы, 
повышении продуктивности пушных зверей и снижении затрат на производство единицы продукции звероводства.

Нарушение хозяйственных связей звероферм и предприятий перерабатывающей промышленности обусловило перевод звероводства на корма с низкой биологической ценностью. В связи с этим изучение и использование биологически активных веществ приобретает особое значение.

В структуре себестоимости шкурковой продукции звероводства на долю кормов приходится около 70\%. При этом $65 . .70 \%$ рациона состоит из дорогостоящих кормов, поставляемых мясо- и рыбоперерабатывающей промышленностью. Одним из основных резервов снижения себестоимости продукции пушного звероводства наряду с совершенствованием существующих пород и методов отбора племенного молодняка, дальнейшей механизации основных процессов обслуживания животных, является внедрение в кормлении зверей новых, нетрадиционных биологически активных веществ.

Интенсивное ведение отраслей животноводства предопределяет создание максимально однородных технологических групп при выращивании молодняка. Многими учеными и практиками животноводства осуществляется поиск мер, направленных на создание выровненных одновозрастных групп животных. По данным И.Е. Мозгова (1964, 1979) около половины поголовья молодняка сельскохозяйственных животных растет слабее физиологических возможностей и около 20-25\% резко отстает в росте. Эта проблема приобретает особую актуальность тогда, когда животным не создаются оптимальные условия для максимальной реализации их генетических возможностей.

Животные не могут существовать независимо от окружающей среды, их организм использует ресурсы среды и в тоже время преодолевает воздействие её неблагоприятных факторов.

Размеры взрослых животных обусловлены, прежде всего, наследственностью. Однако в условиях неполноценного кормления и 
содержания, наследственные задатки могут не реализоваться и потенциально крупные звери останутся мелкими. Молодняку пушных зверей свойственен короткий период интенсивного роста. Задержка роста в это время в большинстве случаев полностью не компенсируется впоследствии. Рост, развитие и состояние здоровья животных - неразрывно связанные процессы. Следовательно, для улучшения их общего состояния целесообразно использовать различные фармакологические средства.

При интенсивном ведении животноводства высокая резистентность стада, породы или популяции ценится не менее чем высокая продуктивность. Такие животные способны наиболее полно проявлять генетический потенциал продуктивности, обеспечивая высокую рентабельность производства продуктов животноводства (Балакирев Н.А., Кузнецов Г.А., 2006; Устинов Д.С., 1976; Фурдуй М.С., 1990, 1992; Балакирев Н.А., Кладовщиков В.Ф., Демина Т.М., Квартникова Е.Г., Перельдик Д.Н. и др., 2007). В ряде работ показана возможность улучшения развития животных, повышения их продуктивности и резистентности после действия различных биологически активных веществ (Балакирев Н.А., 1991, 2002; Балакирев Н.А., Кузнецов Г.А., 2006; Рапопорт О.Л., 1985, 1986; Найденский М.С., 1996; Новикова Н.Н., 1999, 2001; Киселев В.Л., 2004.).

Для повышения защитных сил организма большое значение имеют факторы, влияющие непосредственно на активизацию адаптационных способностей и иммунобиологической реактивности организма животных, в том числе и биологические стимуляторы различной природы.

К настоящему времени, несмотря на значительную изученность проблемы использования биологических стимуляторов многие аспекты их практического применения в животноводстве требуют дальнейшей разработки и обоснования. Вместе с тем недостаточно изучена эффективность применения биологически активных препаратов с целью стимуляции резистентности и повышения продуктивности для разных видов 
и возрастных групп животных (Найденский М.С., 1996; Вагина М.С., 2005).

Вышесказанные исследования были проведены в наиболее благоприятных климатических условиях.

Наши исследования были направлены на решение проблемы, позволяющей с помощью экологически безопасных биологически активных веществ, способствовать усилению компенсаторных процессов у растущего гипотрофичного молодняка животных, повышению резистентности их организма и экономической эффективности его выращивания в суровых природно-климатических условиях Республики Саха (Якутия).

\section{1. Теоретические предпосылки к использованию}

\section{биологически активных веществ в пушном звероводстве Якутии}

\section{1. Характеристика хозяйственно-полезных признаков серебристо-черных лисиц}

В Якутии, как и в других районных нашей страны, в X1X веке занимались выкормочным звероводством. В Верхнеколымском улусе в 90-х годах X1X века за счет таких зверей заготавливалось 15-20\% всех шкурок лисиц. В двадцатых годах прошлого века отдельные любители пытались разводить лисиц в неволе. Известно, что такое разведение лисиц проводилось в Верхоянском и Олекминском районах. Современное пушное звероводство в Якутии началось с организации в 1936 г. в Южно-Саккырырской производственно-охотничьей станции звероводческой фермы по разведению серебристо-черных лисиц. Лисиц в количестве 39 голов завезли из зверосовхоза «Бийский» Алтайского края.

Пушное звероводство к концу восьмидесятых годов прошлого века 
нашло широкое признание в Республике Саха (Якутия). Ежегодно улучшались качественные и экономические показатели пушного звероводства. В 1990 г. в совхозах звероводство впервые стало рентабельным. Клеточное звероводство производило и поставляло государству ежегодно более 9\% шкурок лисиц и 2\% голубых песцов от производимых в России (Буковская 3.И., 1999).

C началом внедрения рыночных отношений животноводство Республики Саха претерпело крупные изменения. Резко снизилось поголовье пушных зверей, значительно снизились показатели делового выхода молодняка, сократилось поступление шкурок а их качество существенно ухудшилось.

Проблемы интенсификации производства сельскохозяйственной продукции в рыночных условиях сегодня стоят как никогда остро. Причины кроются не только в спаде производства в стране, отсутствии четкого правового и хозяйственного механизмов реформ, но и в ухудшении научного обеспечения сельского хозяйства Севера.

Анализ данных поголовья клеточных пушных зверей за период 1991 2005г.г. показывает, что если в 1991 г. в республике насчитывалось 15575 голов серебристо-черных лисиц, то в 2005 году их стало всего лишь 4813 голов, что почти в 3 раза меньше. Если проанализировать ситуацию лисоводства в Якутии за последние годы, то можно сделать следующие выводы - поголовье серебристо-черных лисиц в 2005 году по Республике Саха (Якутия) составляло 4813 голов, тогда как в 2004 году насчитывалось 5448 голов. Самое большое количество насчитывает лисиц Абыйский улус 265 голов, также Хангаласский улус - 3337 голов. По итогам 2005 года деловой выход лисиц в республике составил 3,5 головы, тогда как в 2004 году - 3,3 головы на 1 штатную самку, тогда как по зверохозяйствам России этот показатель равен 5,14 головы. Падеж серебристо-черных лисиц всех возрастов по республике в 2005 году составил 2656 голов, что в 2,9 раз 
больше по сравнению с предыдущим годом. В связи с резким снижением поголовья лисиц, уменьшилось и количество получаемых шкурок. Например, в 1998г. выращено и забито на шкурку 17,7 тыс. голов, а в только 2004 году 9,4 тыс. голов (Торговкина Т.А., Мажитова Л.А., Мозолеская Е.Б., Попова Н.П., Пухова А.П., 2006).

Неустойчивая кормовая база и низкий уровень племенной работы привели к тому, что в настоящее время наблюдается низкая воспроизводительная способность клеточных пушных зверей в Республике Саха (Якутия), в частности у серебристо-черных лисиц, т.е. не проявляется генетически обусловленная возможность продуктивности клеточных зверей, повышаются затраты на выращивание молодняка и стоимость шкурковой продукции.

Несмотря на тяжелое положение клеточное звероводство в Якутии «старается выжить» в новых условиях, доказывая тем самым, что пушное звероводство может развиваться.

Сельское хозяйство Якутии - особо сложная производственная, социально-экономическая и экологическая система, где земледелие и животноводство развиваются в чрезвычайно суровых природноклиматических условиях, не имеющих аналогов в мире.

Условия содержания и уровень кормления якутских клеточных пушных зверей тесно связаны с природно-климатическими особенностями Якутии. Климат здесь резко континентальный, характеризуется большими колебаниями температур в течение года и недостаточным уровнем осадков. Годовые амплитуды температуры составляют в среднем $62^{\circ} \mathrm{C}$ и достигают абсолютной величины более $100^{\circ}$ С. За год в Якутии выпадает 130-270 мм осадков, т.е. приблизительно столько же, сколько в пустынях Казахстана. Вечная мерзлота так же удерживает атмосферные осадки и талую воду в верхних слоях почвы (Аболин Р.И., 1929, Доленко Г.И., 1913, Шашко Д.И., 1961, 1964). 
Зима в Якутии продолжительная, малоснежная и чрезвычайно суровая; число дней со снежным покровом составляет в году 200-250 дней. Снежный покров за зиму достигает в районах Центральной Якутии $30-35$ см, в Индигирской и Колымской низменности - 40-50 см. В юго-западных и центральных районах республики продолжительность холодного периода со средней суточной температурой ниже $0^{\circ} \mathrm{C}$ составляет 204-219 дней, а на побережьях морей - 255-260. В отдельные дни января температура воздуха на территории Якутии бывает ниже $-60^{\circ}$ С. Средняя температура самого холодного месяца в г. Якутске равна - 43,2, в Оймяконе и Верхоянске - $50^{\circ} \mathrm{C}$.

Несмотря на суровый климат, исключая часть северных районов, в зимние месяцы скорость ветров не превышает 1-3 м/сек. В северных районах, на побережьях морей Лаптевых и Восточно-Сибирского, средняя скорость ветра в среднем достигает 5-7 м/сек, а число дней с метелями равно 60-70 дням в году. В этих районах скорость ветра иногда достигает и ураганной силы (49 - 52 м/сек).

Лето в Якутии короткое, засушливое, но достаточно теплое. Май является весенним месяцем, а сентябрь осенним. Весной на большой территории республики средняя суточная температура воздуха нарастает быстро, а осенью она также быстро падает. Самый теплый месяц в году июль. Температура в жаркие дни достигает $34-38^{\circ}$ С. Средняя плюсовая температура июля в центральных, юго-западных и южных районах равна 17$19^{\circ} \mathrm{C}$, в северных районах $-12-15^{\circ} \mathrm{C}$, на побережье $2-4^{\circ} \mathrm{C}$. Суточная температура составляет $11-14^{\circ}$ С. Заморозки возможны даже в июле. Безморозный период в Якутске колеблется в пределах 95 дней, а число дней с температурой выше $5^{\circ} \mathrm{C}-127$.

Начиная с февраля, когда наступает потепление, воздух в Якутии отличается исключительной прозрачностью. В северных районах зимой наступают полярные ночи, а летом - полярные дни. Наименьшая облачность приходится на лето и осень. Продолжительность солнечного сияния на 
большей территории Якутии близка к 20000 часам. Малая облачность и большая прозрачность атмосферы обеспечивают большую интенсивность солнечной радиации в весенние и летние месяцы. По этому показателю Якутск не уступает Ташкенту.

Вечная мерзлота видоизменила почвообразовательные процессы. Она обуславливает формирование специфических, характерных только для Якутии, режимов почв (теплового, водного, воздушного, солевого и пищевого). Некоторые типы почв в республике, такие как мерзлотно-таежно палевые, мерзлотно-таежно нейтральные и др. вообще не имеют аналогов по сравнению с другими зонами земного шара (Иванов Р.В., 2002).

Сельское хозяйство Республики Саха (Якутия) специализируется, главным образом, на производстве продуктов животноводства. Это обусловлено специфическими экстремальными природно-климатическими условиями и укладом жизни коренного населения.

Несмотря на убыточность производства стратегической задачей республики в области сельскохозяйственного производства остается сохранение и дальнейшее развитие животноводства как основы материальной культуры народов Якутии и средство их существования.

В настоящее время в Якутии занимаются разведением в неволе лисицы, песца, соболя и норки, из них больший удельных вес, более 80\%, приходится на лисицу. Исходя из этого можно считать, что лисоводство в республике имеет наибольшее распространение, а шкурки лисиц клеточного разведения имеют наибольший спрос.

Разведение лисиц, хорошо приспособленных к суровым климатическим условиям, начинается с выращивания молодняка, подготовки к размножению, оценки и отбора их по продуктивности.

В последние годы многие хозяйства Якутии вновь стали завозить племенных лисиц из других зон России с целью их разведения и увеличения продуктивности лисоводства. Однако не везде для завезенных животных 
созданы необходимые условия кормления, ухода и содержания, учета их продуктивности, что затрудняет достоверную оценку их реальных генетических возможностей. До сих пор нет достаточных сведений о продуктивных качествах, энергии роста и развития, воспроизводительной способности и адаптационных возможностях серебристо-черных лисиц, завезенных в Якутию.

Лисица (Vulpes vulpes L.) широко распространена, обитает в Европе, Северной Африке, Азии и в Северной Америке, известны 6 видов.Разводимые в зверохозяйствах животные происходят от вида красная лисица, которой присуща широкая географическая изменчивость как по окраске меха, так и по другим признакам (Каштанов С.Н., 2006).

В конце 19-го века в Северной Америке были предприняты первые попытки разведения и содержания лисиц на фермах. В начале 20-го столетия подобные системы содержания зверей появились в Норвегии, немного позже в Дании и Финляндии (Мударисов Р.М., 2003).

В Россию серебристо-черных лисиц завезли в 1927 г. В 1995г. в России был издан первый Государственный реестр селекционных достижений, допущенных к использованию в которую вошла и лисица. Госреестр выделяет четыре породы (серебристо-черная, бургундская, жемчужная и коликотт) и семь типов (Балакирев Н.А., Кузнецов Г.А., 2006). Из них в Республике Саха (Якутия) разводят в клеточных условиях серебристо-черную лисицу. По зоологической классификации их относят к отряду хищных, семейству псовых, роду и виду лисица.

Размеры тела разводимых в клеточных условиях в Республике Саха (Якутия) колеблются у самок от 59 до 65 см, а у самцов - от 64 до 70см. Средняя живая масса самок в декабре - январе варьирует от 5,00 до 5,50 кг, а самцов - от 5,90 до 6,40 кг. Продолжительность жизни у лисиц составляет 10-12 лет, однако для племенных целей в хозяйствах их используют в возрасте не более 5-7 лет (Буковская 3.И., 1999). 
Серебристо-черная лисица характеризуется черной окраской пигментированных волос и наличием на спине и боках серебристого остевого волоса с белой зоной. Серебристый волос у лисиц может располагаться от основания хвоста до ушей. В этом случае говорят о 100\%-ной серебристости. Нередко такой волос располагается только на части туловища, но всегда его распространение начинается от основания хвоста. По площади, занятой серебристым волосом, определяют процент серебристости: за $75 \%$ принимают площадь от основания хвоста до лопаток, за 50\% - до середины шкурки, 25\% - до 1/4 ее длины (Берестов В.А., 2002). В нашей стране используются два основных способа содержания лисиц и других пушных зверей: в специальных шедах (шедовое содержание) и в отдельно стоящих клетках и шедах - комбинированное содержание. В скандинавских странах, где лисоводство получило очень высокое развитие, в большинстве своем для содержания лисиц применяют усовершенствованные клетки с большей площадью, чем их российские аналоги, имеющие гнездовые боксы и платформы.

Серебристо-черные лисицы имеют сезонный тип размножения. У самок течка бывает раз в году и период гона длится обычно 7-11 суток. Период половой охоты самок продолжается 2-3 сутки. Наступление течки можно определить по поведению зверей и по состоянию наружных половых органов (Мударисов Р.М., 2003).

В зверохозяйствах Якутии сроки спаривания приходятся в основном на более позднее время, чем в Центральной части России, - в марте и заканчиваются в первой половине апреля.

Беременность у лисиц продолжается 51-52 дня. Сроки щенения у лисиц с конца марта до начала мая. Плодовитость самок составляет в среднем 5-6 щенков. Новорожденные щенки лисиц весят 80-100 г.

Полноценный половой цикл у лисиц проявляется в 295-361-суточном возрасте. На основании анализа плодовитости молодых самок была 
установлена ее зависимость от возраста. Наивысшее проявление репродуктивной функции регистрировали у лисиц 2-5-летнего возраста. Возрастной период 1-2 года характеризуется половым созреванием лисицы, такие самки имели более низкую плодовитость. Для животных 6-8 лет было характерно достоверное снижение плодовитости, у них отмечалось большое число случаев бесплодия, абортов и неблагополучных щенений.

На основании анализа результатов гона, щенения и других показателей воспроизводства серебристо-черных лисиц разных возрастных групп (молодых и взрослых) был выявлен больший процент холостых и пропустовавших самок у молодых лисиц. В этой возрастной группе также было установлено большее число неблагополучных щенений. У взрослых самок отмечалось меньшее количество мертворожденных щенков и меньший отход щенков до регистрации (Мударисов Р.М., 2003).

В работах М. Павлова (1954; 1966) отмечается, что новорожденные щенки серебристо-черных лисиц имеют укороченные конечности и длинное тело. В первые два месяца у щенков наиболее быстро растут конечности и значительно отстает рост тела в длину. С двух до четырех месяцев от рождения у лисят быстрее растет туловище, а также конечности и голова. С четырех до семи месяцев быстрее увеличиваются обхват и ширина груди. В первые дни жизни у них интенсивно растут конечности, затем голова и туловище. К 5-6 месячному возрасту щенки лисиц приобретают пропорции взрослых животных. (Буковская 3.И., 1999; Мударисов Р.М., 2003).

Н.Ш. Перельдик (1956) разделил цикл развития щенков лисиц на 3 периода. Первый продолжительностью 45 суток охватывает время кормления молоком матери и характеризуется высокими требованиями организма к притоку питательных веществ для роста. Второй период - с 1,5до 3,5-месячного возраста - характеризуется повышенной способностью щенков к росту и отложению в теле белка и жира. В третий период роста молодняк лисиц предъявляет высокие требования к уровню кормления. 
Увеличение живой массы осенью, даже кратковременное, бывает сопряжено с ухудшением воспроизводительных качеств самок.

В период полной зрелости волосяного покрова - в первый год жизни молодняка (конец октября - начало ноября) - проводят бонитировку всех лисиц, предварительно отобранных на племя, а также молодняка от самцов и самок, подлежащих оценке по качеству потомства согласно требованиям отраслевого стандарта (ОСТ 1010-86).

Убой проводят при полном созревании волосяного покрова у молодняка из пользовательной части стада (середина ноября) (Берестов B.A., 2002).

Волосяной покров серебристо-черных лисиц, как и у большинства пушных зверей, состоит из трех типов волос: направляющих, остевых и пуховых. Пуховые волосы, по мнению некоторых авторов (Кузнецов Г.А.., 1952, 1953), следует подразделять на два типа: собственно пуховые и переходные. Остевые волосы имеют зональную окраску: черное или темно-серое основание, белую зону (серебристое кольцо) и черные кончики, образующие вуаль на фоне белой зоны. Остевые волосы вместе с направляющими часто объединяют в одну группу и называют кроющими.

В соответствии со стандартом, наиболее желательным типом серебристо-черных лисиц по окрасу являются звери, имеющие иссиня-черную ость (без признаков буризны), темно-серую подпушь, чисто-белое серебристое кольцо шириной 10... 15 мм, нормальную выраженность вуали и 100\%-ную серебристость.

Характерным для лисиц является то, что самцы имеют в среднем более длинный волос, чем самки; у взрослых зверей, по сравнению с годовалыми животными, зимний волос обычно несколько длиннее (Ильина Е.Д, Кузнецов Г.А., 1983).

Несмотря на длительное разведение серебристо-черных лисиц в искусственно созданных человеком условиях, они не утратили сезонной 
выраженности таких процессов, как размножение, линька и мехообразование. Сезон размножения у лисиц проходит в феврале - марте после того, как животные достигают хорошей упитанности, а их меховой покров - полного развития и созревания. Линька у лисиц начинается после начала репродуктивного сезона и приходится в основном на март - апрель. При этом взрослые самки начинают линять раньше самцов и молодняка, а линька у беременных самок проходит интенсивнее, чем у холостых.

Летнее опушение у молодняка лисицы появляется к 2-2,5-месячному возрасту. В конце июля - августе оно начинает выпадать и заменяется зимним волосом. Линька летнего волоса заканчивается осенью, а зимнее опушение окончательно формируется в ноябре - декабре. У взрослых лисиц зимнее опушение развивается при одновременном сохранении и отрастании летнего волоса (Мударисов Р.М., 2003). Данные биологические особенности присущи и лисице, разводимой на территории Якутии (Буковская 3.И., 1999; Черкашина А.Г., 1998).

Таким образом, можно сделать вывод, что одним из ценнейших объектов звероводства является серебристо-черная лисица, поскольку шкурки этих животных очень высоко ценятся на мировом рынке. В звероводческих хозяйствах России, в том числе и в Республике Саха (Якутия), серебристо-черная лисица получила широкое распространение. Имеется ряд научных работ, посвященных вопросам технологии содержания, кормления, разведения, выращивания молодняка, использования биологически-активных веществ в рационах, улучшения показателей воспроизводства разводимых на фермах лисиц и качества получаемых шкурок в условиях резко континентального климата Якутии. Однако эти вопросы изучены недостаточно глубоко и требуют проведения дополнительных исследований.

\section{2. Причины недоразвития молодняка пушных зверей}

Гипотрофия молодняка - нарушение роста и развития новорожденных животных вследствие расстройства их питания во внутриутробном и 
внеутробном периодах жизни, наблюдается у молодняка всех сельскохозяйственных животных.

Под гипотрофией в настоящее время понимают длительное, хроническое заболевание, сопровождающееся нарушением трофической функции организма - пищеварения, обмена веществ, с задержкой физического и статического развития.

У гипотрофичных щенков снижены иммунобиологические защитные силы организма, в связи, с чем среди них наблюдаются высокий процент заболеваемости, смертности, получение шкурковой продукции низкого качества (Владимиров А.В., 2002; Квартникова Е.Г., 2002).

Причиной недоразвития молодняка пушных зверей является стрессфактор. Стресс, как отрицательный фактор для нормальной репродуктивной функции необходимо учитывать в звероводческой практике. Он может проявиться у самок пушных зверей при различных формах влияния на центральную нервную систему. Сюда можно отнести: различные шумы, хождение посторонних людей без надобности по шедам во время беременности у зверей (в этот период у них повышен защитно-охранительный синдром), взятие в руки без особой необходимости беременного зверя, вакцинация, взятие крови, транспортировка, перегруппировка. У щенков стрессовое состояние может возникнуть при отъеме их от матерей, при бирковании ушей, перегруппировке и других состояниях напряжения.

У самок в результате стресс-факторов могут быть неблагополучные роды, рождение мертвых и гипотрофичных щенков, рассасывание эмбрионов, аборты. Все это ведет к нарушению цикла воспроизводства у зверей, к недополучению большого количества щенков (Владимиров А.В., 2002).

Срок щенения лисиц довольно растянут - март-май. Щенки рождаются слепыми, беззубыми, с плотно замкнутыми слуховыми проходами. Они большеголовы, с удлиненным телом и относительно короткими конечностями и хвостом. Новорожденные щенки покрыты эмбриональным пухом. У 
многоплодных животных новорожденные из одного помета по своим морфофизиологическим свойствам неодинаковы. Внешним проявлением степени физиологической зрелости организма при рождении является его живая масса (Демина Т.М., 1980). Средняя масса щенка лисицы при рождении колеблется от 80 до 100 г. Масса щенка в возрасте 1 дня - это наиболее характерный показатель, когда материнский организм не получает в составе рациона необходимые питательные вещества для обеспечения роста развития плода или в результате некоторых условий не в состоянии ассимилировать их из корма, страдает организм матери и, особенно плод, в котором нарушается питание. Масса щенков, таким образом, зависит от состояния обмена веществ в организме матери. Исследованиями установлено, что врожденные гипотрофики норок в среднем отстают в росте на 44,4\% (на 1-й день после рождения). Абсолютные массы внутренних органов у гипотрофиков (сердце, легкие, печень, правая почка, селезенка) значительно ниже, чем у нормотрофиков, они недоразвиты, отмечается гипоплазия.

Основные клинические признаки гипотрофиков - адинамия, отсутствие или слабое проявление сосательных рефлексов, нарушение ритмов дыхания, пониженная температура, недоразвитие кожного и волосяного покровов, синюшность слизистых оболочек и др. (Владимиров А.В., Владимиров В.А., 2002).

Биологической особенностью клеточных пушных зверей является высокая интенсивность роста в первые месяцы жизни. У молодняка норок к 4х месячному возрасту масса тела увеличивается более чем в 100 раз по сравнению с массой при рождении, а у молодняка лисиц и песцов - больше, чем в 40 раз (Перельдик Н.Ш., Милованов Л.В., Ерин А.Т., 1987). Поэтому несбалансированное кормление зверей в этот период роста животных может привести к нежелательным последствиям, в частности, негативно повлиять на конечные размеры животных и их воспроизводительную способность (Fink R., Tauson H., 2004). 
В хозяйствах Якутии репродуктивные функции клеточных зверей - в пределах физиологической нормы. При этом продолжительность беременности и плодовитость зверей не отличаются от разводимых в Центральной зоне России. Исходя из этого, основными определяющими факторами воспроизводства, роста и развития молодняка зверей в хозяйствах Якутии являются кормовые и сезонные погодные условия.

Для высших животных главным «пусковым» регулятором воспроизведения является световой режим (Коченов С.С., 1976; Selim et. al., 2004; Szendro et.al.,2004). Колебания температуры воздуха сказываются на воспроизводительных функциях только при экстремальных значениях. Этот фактор, наряду с неудовлетворительными условиями кормления, снижает обмен веществ, воспроизводительные возможности, что отрицательно сказывается на росте и развитии молодняка.

Среднемесячная температура в ноябре составляет -28 град., декабре -39 град., январе -43,2 град., феврале -35,9 град., марте - 22 град. Цельсия при скорости ветра 1,3...2,0 м/с (Иванов Р.В., 2000).

При выращивании молодняка домашних животных наблюдаются большие различия в живой массе отдельных особей.

На рост и развитие молодняка влияют генетические и внешние факторы (Swinkeis Y., 1998; Schneider Y., 1999) К генетическим факторам можно отнести хромосомные аномалии и полиплоидию.

Для получения крепкого и здорового молодняка большое значение имеет использование генетических систем при подборе пар для определения об иммуногенетической сочетаемости родительских генотипов (Лисина И.С., 1969; Никитин Л.К., Бабеев А.А., 1977; Меркурьева Е.К., 1979). Установлено, что потомство, полученное от сочетания родительских пар с едва заметным антигенным различием, характеризовалось более высокой скоростью роста и повышением сохранности на 18-30\%.

Немаловажное значение имеют и паратипические факторы, влияющие 
на рост и развитие всего гнезда в целом. Среди молодняка зверей существуют различия не только в живой массе отдельных зверей внутри помета, но и между животными различных гнезд.

Проведенные в России и за границей опыты в течение многих лет показали, что задержка в развитии животных из-за недостаточного кормления или болезни в более ранних периодах индивидуального развития, позднее не может быть полностью компенсирована (Свечин К.Б., 1956, Новиков Е.К., 1971). У гипотрофичных животных наблюдаются различные изменения пропорций телосложения животного, возникают изменения в соотношении различных органов и тканей тела животного, а также в физиологических и биохимических функциях организма, которые значительно отличают его от животного, в развитие которого не было искусственно вызванных задержек.

Установлено, что многие из этих изменений не могут быть компенсированы последующем улучшении условий жизни животного даже в том случае, когда его живая масса выравнивается (Е.А. Богданов, 1926; Е.Ф. Лискун, 1931; К.Б. Свечин, 1976). Вместе с тем это не исключает способности организма компенсировать временное замедление развития в результате недокорма или болезни при последующем улучшении условий кормления и содержания. Компенсация временных задержек в развитии является неотъемлемым свойством организма. Основополагающими здесь являются причины, степень и продолжительность недоразвития организма, чем и определяется возможная степень последующей компенсации этого недоразвития (Овсянников А.И., 1940; П.Д. Пшеничный, 1957, 1961; К.Б. Свечин, 1952, 1967).

Исследования Me Canse et. al. (1968), Wilson M. (1980) и др. было установлено: а) при полном подавлении роста на ранних этапах жизни, животные не достигнут нормальных размеров, как бы полноценно не было последующее кормление, б) на характер компенсационного роста влияют 
следующие основные факторы: природа недоедания (голодание белковое, энергетическое и т.д.), глубина и длительность периода задержки роста, стадия развития животного в момент начала задержки роста и характер питания после окончания периода голодания.

В результате исследований было установлено, что угнетение роста животных в постнатальный период компенсируется за счет удлинения периода активного роста. Отстающие в росте молодняк догоняет или даже обгоняют по массе нормально растущих особей. Однако может иметь место и неполная компенсация, в том случае, например, когда период угнетения роста был достаточно большим, г) величина животных, родившихся в многоплодных пометах зависит главным образом от условий дальнейшего выращивания.

Многочисленные исследования свидетельствуют, что среди исследователей нет единого мнения о возможности полной компенсации задержек роста. Борисенко Е.Я. (1955), Шаумян В.А.(1951), Гаркави О.В. (1952), следуя высказываниям Н.П. Чирвинского (1891, 1926, 1949), считают, что длительные задержки роста в молодом возрасте в дальнейшем полностью не компенсируются.

В 1925 году А.А. Малигонов установил правило высокой пластичности, по которому при благоприятных условиях организм животного развивается лучше, а при недостаточном кормлении наблюдается его недоразвитие - принцип «недоразвития» Чирвинского - Малигонова. Суть его заключается в следующем: степень недоразвития различных тканей и органов находится в определенной связи с интенсивностью роста того или иного органа и ткани; органы с интенсивным ростом страдают (недоразвиваются) при скудном питании больше, чем органы с менее интенсивным в этот период ростом. При усиленном питании животного в определенный период его развития наиболее интенсивно будут расти и развиваться те части и органы, которые в данный период отличаются наибольшей естественной скоростью роста. Стало бесспорным положение о невозможности полной компенсации 
задержки роста сельскохозяйственных животных. Научной основой этого утверждения явилась теория независимости процессов развития от условий кормления при полной зависимости от них процесса роста. К.Б. Свечин (1964, 1968) отмечал, что степень компенсации недоразвития организма, вызываемого временным голоданием, прямопропорциональна последующим условиям питания животного, обратно пропорциональна его возрасту, силе и продолжительности неблагоприятных условий кормления (Новикова Н.Н., 2001).

\section{3. Использование биологически активных веществ в} кормлении пушных зверей

В настоящее время в кормлении пушных зверей используют сотни различных кормовых добавок, среди которых отходы медицинской, пищевой, рыбоперерабатывающей промышленности, продукты микробиологического синтеза, аминокислоты, витамины, ферменты, антиоксиданты, вкусовые вещества и др. Все эти добавки необходимо применять очень грамотно.

В рационах клеточных пушных зверей последние годы все чаще стали применять биологически активные вещества: аминокислоты, витамины, ферменты, адаптогены, антиоксиданты, минеральные вещества и др.(Квартникова Е.Г., 2002; Балакирев Н.А., Кузнецов Г.А., 2006).

Некоторые из этих соединений (витамины, аминокислоты, микроэлементы) являются жизненно необходимыми для нормального протекания метаболических процессов в организме животных. Их недостаток или, напротив, избыток в рационах приводит к глубоким нарушениям почти всех физиологических процессов. Другие биологически активные вещества, хотя и не являются ежедневно необходимыми для нормальной жизнедеятельности животных, поскольку их временное отсутствие не вызывает нарушения обмена веществ и нормальных физиологических 
процессов, тем не менее достаточно широко применяются в качестве стимуляторов роста и продуктивности животных (Балакирев Н.А., Кузнецов Г.В., 2006).

Развитие конкурентоспособного звероводства должно базироваться на основе создания системы рационального кормления (Балакирев Н.А., Кладовщиков В.Ф., Демина Т.М., Квартникова Е.Г., Перельдик Д.Н. и др., 2007). Современное состояние отечественной кормовой базы не удовлетворяет требованиям отрасли ни в количественном отношении и сегодня отрасль нуждается в принятии срочных мер по расширению производства дешевых отечественных кормов, широкого применения новых нетрадиционных кормов и биологически активных веществ, разработке и применения рецептов комбикормов и комбикормов-концентратов. Перспективно широкое изучение новых ингредиентов и биологически активных веществ, без которых современное кормление невозможно представить.

Bсе это вместе взятое укрепит кормовую базу отрасли, позволит снизить себестоимость пушнины и повысит рентабельность отрасли (Балакирев Н.А., 2002).

Среди биологически активных веществ наибольшего внимания заслуживают витаминные препараты, макро- и микроэлементы, биогенные стимуляторы и другие препараты. Научно-обоснованное применение этих препаратов позволяет значительно сократить падеж молодняка, в частности от желудочно-кишечных и легочных заболеваний, а также от болезней обмена веществ. Их используют для профилактики и лечения многих заболеваний, стимуляции роста молодняка, повышения воспроизводительной функции самок и балансирования рационов. Наукой и практикой доказано, что с помощью различных химических средств даже при существующих рационах кормления можно добиться максимальной сохранности 
нарождающегося молодняка и вырастить его для воспроизводства стада (Балакирев Н.А., 1991, 2002).

Большинство биологически активных веществ не обладает энергетическими свойствами, но заметно стимулирует некоторые физиологические функции животных, что способствует увеличению продуктивности и повышению их общей сопротивляемости заболеваниям.

Что касается ускорения роста животных от добавления к несбалансированному рациону витаминов, ферментов, макро- и микроэлементов, аминокислот, го ускорение роста есть результат стимуляции, компенсации, то есть восполнения недостающих, но весьма необходимых для обеспечения нормальных физиологических процессов в живом организме биологически активных веществ (Перельдик Н.Ш., Милованов Л.В., Ерин A.T., 1981, 1987).

В повышении защитных сил организма важное значение имеют факторы, влияющие непосредственно на активизацию адаптационных способностей и иммунобиологической реактивности организма животных, в частности биологические стимуляторы различной природы. Несмотря на значительную изученность проблемы использования биологических стимуляторов многие аспекты их практического применения в животноводстве и ветеринарии требуют дальнейшей разработки и обоснования (Вагина М.С., 2005).

По мнению Синещекова А.Д. (1974), Keith Е.А. (1988) в основе действия стимуляторов лежат усиление пищеварительных, синтетических и обменных функций желудочно-кишечного тракта и регуляторные механизмы газообмена и обмена энергии. Выявлено, что биологически активные вещества оказывают положительное влияние на использование кормов, усиливая переваривающую способность пищеварительного аппарата, то есть из корма извлекается большее количество питательных веществ. Это открывает возможности для нормального развития даже при некотором 
недостатке корма. Но это не означает, что стимуляторы могут заменить собою часть корма, они лишь активаторы обмена веществ, которые должны быть представлены организму из вне. Также известно, что биостимуляторы, оказывая влияние на белковый, липидный и минеральный обмены, в большей мере оказывают влияние на обмен аминокислот, высокомолекулярных жирных кислот.

В некоторых случаях отдельные стимуляторы, активизируя физиологические процессы, косвенно могут в какой-то мере восстанавливать и регулировать нарушенные процессы, а главное, усиливать функции организма, повышая этим его сопротивляемость и устойчивость к любому болезнетворному фактору, развитию патологического процесса.

Следовательно, биологически активные вещества, не обладая антибактериальными свойствами (как антибиотики), как правило, снижают на 3-5\% падеж животных, особенно молодняка. А при даче биостимуляторов недоразвитым, истощенным или переболевшим животным они могут дать дополнительный прирост на 50-100\%. Биологически активные вещества не являются лекарственными веществами. Принципиальным различием между ними является то, что стимуляторы усиливают физиологические процессы в пределах нормы, а не регулируют их, что свойственно больше лекарственным веществам (А.Д. Синещеков, 1974; Ю.П.Балаж,1980; Strzetelski; Yuliusz, 1994).

Антибиотики обычно используют не только для целей стимуляции роста и развития, а так же для преодоления неблагоприятного микробиологического фона в организме животного. Вместе с тем антибиотики могут проявить и черты биологически активного соединения Примечательно, что в высокоразвитых странах в животноводстве не практикуется ее широкое применение. Она выступает в роли средства улучшения отношений между генами и цитоплазмой и потому лучшего выполнения наследственной нормы развития (Г.Н. Шангин-Березовский, 
1978).

Среди выше перечисленных соединений практика настороженно относится к гормонам, так как в свое время была показана возможность накопления стероидных гормонов в мясе откормочного скота, что может вызвать у человека злокачественные новообразования. (И.Е. Мозгов, 1979; А.Л. Падучева, 1967; П.Е. Радкевич, 1969). Однако, в последнее время было показано, что применение гормона роста существенно увеличивает удои лактирующих коров (Новикова Н.Н., 2001).

Эффективность действия биологически активных веществ (стимуляторов) зависит от условий кормления, возраста, пола и длительности применения препаратов, что необходимо учитывать при выборе стимулирующих средств и их сочетаний (Радкевич П.Е.,1966, 1970; Swennen Buyse J., Decuypere R., 2005)

Научные исследования и широкая производственная практика в стране и за рубежом показали, что антибиотики можно использовать не только в лечебных целях, но и как кормовые добавки для повышения продуктивности и стимуляции роста молодняка (Таранов Т.С., Анакина Ю.Г., 1981). По их данным, скармливание антибиотиков (кормогризин, пенициллин, левомицетин и другие) способствуют сокращению эмбриональной смертности, снижает количество мертворожденных щенков, повышает деловой выход молодняка.

Кормовые антибиотики с целью стимуляции роста животных целесообразно применять не только при выращивании молодняка пушных зверей. Так, по мнению И.И. Дукур, А.И. Деминой $(1960,1963)$ введение в рацион антибиотиков позволяет сократить отход от желудочно-кишечных и простудных заболеваний, повышает их жизнеспособность. Отмечалось также улучшение качества шкурок за счет сокращения их дефектности. 
В результате работ, проведенных М.В.Котовой (1962) установлено, что добавление в корм различных антибиотиков повышает живую массу и длину тела молодняка зверей, что способствует получению более крупного размера.

Для хорошего воспроизводства поголовья и получения крепкого, здорового приплода необходимо обеспечивать зверей достаточным количеством витаминов. Будучи вплетены в сложную сеть обменных реакций, витамины оказывают воздействие на разнообразные физиологические процессы. Исследованиями установлено положительное влияние введения в рационы пушных зверей витаминов. При этом снижается их заболеваемость, усиливается рост молодняка, повышается воспроизводительная способность самок. В ряде работ отмечается, что витамины улучшают морфологические и биохимические показатели крови, приближая их к физиологической норме. Влиянию микроэлементов на рост и развитие пушных зверей, качество волосяного покрова посвящены работы многих авторов. По их данным, при введении в рационы солей микроэлементов стимулируется рост животных, увеличивается их живая масса, повышается качество шкурок, в основном за счет снижения дефектности и увеличения размера (Перельдик Н.Ш., Милованов Л.В., Ерин А.Т.,1987; Bailoni L., Cerchiaro I., 2005; Tumova E., Zita L., Stolc L., 2006).

В настоящее время более полно исследовано значение таких микроэлементов, как железо, медь, кобальт, магний, цинк, йод. Они указывают на то, что добавка в рацион молодняка пушных зверей микроэлементов оказала положительное действие на результаты воспроизводства, на живую массу молодняка, площадь шкурки, а также на качество волосяного покрова (Макридина К.В., 1975; Балакирев Н.А., Кузнецов Г.А., 2006).

Имеются данные, что подкормка комплексом солей микроэлементов оказывает более эффективное влияние на продуктивность зверей, чем каждый микроэлемент отдельно. Установлено, что при этом снижается их 
заболеваемость, повышается плодовитость, усиливается рост молодняка, снижается дорегистрационный отход, в результате чего увеличивается выход молодняка на самку (Перельдик Н.Ш., Жукова В.И., 1974) .

В последние годы в звероводстве широко практикуется введение в рацион пушных зверей гормональных препаратов. Было установлено, что гормоны оказывают положительное воздействие на физиологические процессы в организме этих животных, способствует быстрому росту и развитию молодняка, повышают репродуктивную активность и жизнедеятельность приплода. Многочисленные исследования свидетельствуют об эффективности применения биогенных стимуляторов, ускоряющих рост, повышающих продуктивность и улучшающих различные жизненные функции, связанных с обменом веществ в организме пушных зверей. Особый интерес в этом плане имеют легкодоступные синтетические аналоги. Исследования, проведенные П.П.Орловым, Л.А.Бурдель, Б.Ф.Дужко, М.Р.Воронковым, В.М. Дьяковым (1989), показали, что введение крезацина в рацион кормления молодняка норки способствует интенсификации роста зверей и их зимнего волосяного покрова, улучшению качества снятых с них шкурок.

Проведенные исследования по введению в рацион пушных зверей белковых гидролизатов показали, что дача с кормом положительно сказывается на воспроизводительной способности зверей, значительно сокращает отход молодняка (Берестов В.А., 1981). Препараты оказывают благотворное влияние на молочность самки, рост и развитие щенков. Применение гидролизатов стимулирует половую деятельность самок и самцов, а также значительно сокращает лактационное истощение у самок.

Исследования, проведенные Н.А.Балакиревым (1991), показали, что синтетические антиокислители (ионол и дилудин) положительно влияли на рост и развитие молодняка, а также на размер и качество шкурок. В 
результате работ, проведенных Я.И. Спруж, С.В. Путинским, А.А. Забутым, П.Н. Ромысловым (1975), было установлено, что введение порошка дилудина в корм молодняку норок стимулировало рост животных и способствовало увеличению площади шкурок. Кроме того, было установлено, что препарат предотвращает дегенеративные изменения в печени. Положительные результаты были получены при введении в рационы зверей эрготропиков (Рапопорт О.Л., 1986). Исследования показали, что введение эрготропиков способствует повышению выхода щенков на основную самку и увеличению размера тела зверей.

В последние годы открыта высокая активность ряда химически разных соединений: нитрозодиметилмочевины, алкилсульфатов и некоторых других органических веществ. В опытах на норках, песцах и лисицах, проведенных В.Л.Адамовым, Г.Н. Шангиным-Березовским, Ю.А.Перчихиным $(1981,1982)$ установлено, что разовое введение микродоз супермутагенов может повысить плодовитость самок на 1,5-2 щенка по сравнению с контролем, активизируется и функционирование половых желез. Выявлено последствие биостимуляторов на плодовитость и резистентность самок на следующий год.

Биологически активные вещества широко применяются в рационах сельскохозяйственных животных, что способствует ускорению их роста и развития, повышению их продуктивности. При этом не только сохраняются, но и более активно проявляются закономерности, присущие здоровому организму (Мозгов И.Е., 1964, 1974, 1979).

В пушном звероводстве в последние десятилетия широко используются БАВ как природного происхождения, так и синтезированные. В результате исследований значительного количества различных биологически активных препаратов установлено положительное влияние отдельных из них на 
увеличение делового выхода щенков, повышение резистентности зверей к заболеваниям, улучшение качества шкурок, уменьшение расхода кормов, тогда как некоторые препараты были мало - или даже не эффективными (Мударисов P.M., 2003).

Многочисленные исследования свидетельствуют, что природные цеолиты и бентониты обладают совокупностью сорбционных, ионообменных и каталитических свойств, принимают участие в транспортировке, активации и пролонгировании действия ферментов и гормонов, стабилизации кислотнощелочного равновесия в пищеварительной системе, поддержании ионного равновесия натрия и кальция. Природные цеолиты и бентониты обладают детоксикационным действием по отношению микотоксинам, нитратам, нитритам, адсорбируют продукты метаболизма, в связи с чем находят применение в животноводстве (Колодезников К.Е., Степанов В.В., Матросова Т.В., 1991).

Широкому применению фитотерапии все еще препятствует недостаточная изученность с помощью современных биохимических методов биологически активных веществ, содержащихся в растениях. Изучение их представляет большую трудность, чем изучение действия чистых химических соединений. Некоторые биологически активные вещества растений вообще пока не выделены в чистом виде, а некоторые действуют только в присутствии других, иногда даже неизвестных соединений. В большинстве растений содержится несколько биологически активных веществ.

Наличием различных биологически активных веществ во многих видах лекарственных растений обусловлено их лечебное действие. При поступлении в организм животных и человека биологически активные вещества проявляют физиологически свои активные свойства и оказывают целебное действие. Они называются действующими веществами, имеют разнообразный состав и относятся к различным классам химических соединений. В частности, это алкалоиды, гликозиды, дубильные вещества, сапонины, горечи, пигменты, 
флавоноиды, эфирные масла, слизи, смолы, бальзамы, ферменты, полисахариды, органические кислоты, фитонциды, витамины, антибиотики, минеральные вещества и др. Количество этих веществ в растениях зависит от климато-географических условий их произрастания, периода и фазы роста, времени сбора, способа сушки и условий хранения. (Мударисов Р.М., 2003).

Исследования, проведенные Рапопортом О.Л., Голушковой М.А. (1989); Давыдовым А.Б., Солодкая Т.И., Цвик Б.С. (1998) свидетельствуют, что в начальный период роста подкожная имплантация голубым песцам мелакрила способствует ускорению созревание зимнего меха на 4-5 недель. У норок «мелакрил» оказал положительное влияние на общее состояние зверей: укрепил иммунную систему и обеспечил более спокойное поведение животных; улучшил рост и развитие молодняка; способствовал более раннему созреванию зимнего опушения - в среднем на 30-70 суток раньше срока.

П.П. Орловым, Л.А. Бурделем, Б.Ф. Дужко, М.Г. Воронковым, В.М. Дьяковым (1989) при изучении действия биостимулятора крезацина (синтетический аналог фитогормонов) на репродуктивные качества самок серебристо-черных лисиц установлено, что введение препарата в корм животных в дозе 5 мг/кг за 10 суток до гона, через 5 суток после оплодотворения и за 5 суток, перед щенением способствует сокращению количества самок, не давших приплода, на $15 \%$, отсутствию пропустовавших лисиц. В опытной группе отход щенков до регистрации был на $2 \%$ ниже, чем в контроле. Выход щенков на одну основную самку в опыте составил 5,1головы, тогда как в контроле - 4,1.

С целью оптимизации кормления, повышения биологической полноценности и коэффициента полезного действия рационов, интенсивности роста молодняка песцов и норок, качества шкурок и рентабельности их производства, Гайнуллина М.К. (2006) рекомендует 
использовать при выращивании щенков в период после отъема до убоя в качестве кормовых добавок цеолитсодержащие мергель и глину ТатарскоШатрашанского месторождения, цеолитовый туф Холинского месторождения, бентонитовую глину Верхне-Нурлатского месторождения и диатомитовую породу Инзенского месторождения в количестве 0,5\% (норкам) и 1,0\% (песцам) от массы корма. В условиях повышенного техногенного загрязнения окружающей среды для профилактики экзогенных микроэлементных токсикозов (токсикопатий) и выведения из организма тяжелых металлов в рационы щенков песцов и норок она рекомендует включать природные минеральные сорбенты (цеолитсодержащие мергель и глину Татарско-Шатрашанского месторождения, цеолитовый туф Холинского месторождения, бентонитовую глину Верхне-Нурлатского месторождения и диатомитовую породу Инзенского месторождения) в количестве 1,5\% от массы корма.

В настоящее время актуально использование в клеточном звероводстве естественных метаболитов, к которым относятся органические кислоты: лимонная, янтарная, фумаровая и другие. Установлено, что янтарная кислота, введенная в рацион норок, стимулирует их репродуктивные качества, оказывает влияние на энергетический метаболизм щенков и лактирующих самок. Она также стимулирует рост и развитие животных, усиливает аэробную фракцию лактатдегидрогеназы, нормализует активность ферментов в крови, оказывает положительное влияние на величину и качество шкурковой продукции (Тютюнник Н.Н., Кожевникова Л.К., Кондрашова М.Н., 2002).

Янтарная кислота введенная в рацион норок в дозах 5 и 10 мг/кг живой 
массы оказывает иммуностимулирующее воздействие на организм зверей. Метаболит способствует увеличению живой массы опытных норок на 25,4\%, концентрации гемоглобина на $13,1 \%$ и увеличению в крови зверей количества эритроцитов на 7,4\% (Березина О.В., 2000).

Как отмечено Квартниковой Е.Г. (2002) в последние годы состояние зверей как в крупных звероводческих комплексах, так и в небольших подсобных хозяйствах стало тревожить все больше и больше. Это рождение ослабленного, а порой и нежизнеспособного потомства, повышенный отход зверей, получение шкурковой продукции низкого качества.

Анализ сложившегося положения свидетельствует о том, что причины неблагополучия имеют многофакторный характер. Это и не полностью сбалансировано кормление, и массовая токсическая дистрофия печени, возникающая при наличии в кормах токсических элементов, и каннибализм, нередко наблюдаемый по причине нарушения обмена веществ у зверей, и целый ряд дефектов шкурковой продукции.

Действие адаптогенных препаратов (МИК БАК, МИДИУМ, РИБАВ) заключается в том, что они в отличие от антибиотиков воздействуют опосредовано на весь организм, способствуя активизации его скрытых резервных механизмов в случае возникновения неблагоприятных условий. Поэтому их назначают не постоянно, как витамины, а отработанными в каждом конкретном случае курсами.

Ростостимулирующее, иммунологическое и антистрессовое действие антиоксидантов на организм установлено многочисленными работами на разных видах животных и птице (Балакирев Н.А., Зарипова Л.П., 1987; Балакирев Н.А., 1991; Павлова Н.Н., 1995; Лоенко Н.Н., Балакирев, Плеханова Л.Г., 1992, 1998 и др.).

Балакиревым Н.А. в многочисленных научно-хозяйственных опытах $(1989,1990,1991,2006)$ показано влияние различных добавок в корм на рост, размер и качество шкурок норок. Им были изучены следующие 
антиоксиданты - ионол в дозах от 25 до 100 мг, дилудин - 25...75 мг, фенозан - 25... 100 мг, глутамат натрия - 50...300 мг; ферменты - амилосубтилин ГЗх, пектофоетидин ПЮх в дозах от 100 до 400 мг; минеральные добавки бишофит от 70 до 350 мг на голову в сутки 6-7-суточным курсом. Продолжительность использования препаратов была от 60 до 120 сут. (июльоктябрь). Академиком РАСХН Н.А. Балакиревым было установлено, что в большинстве групп энергия роста подопытных норок была достоверно выше контрольных; препараты также положительно влияли не только на размер зверей, но и на качество волосяного покрова. Так, количество шкурок особо крупного размера «А» в подопытных группах было больше, чем в контроле: с добавкой ионола на 9...22\% (в среднем 11\%), дилудина на $2 \ldots 13,7 \%$ (в среднем 4,4\%), фенозана на 2,5.. 18,2\% (в среднем 12\%), пектофоетидина на $14,0 \ldots 24,0 \%$ (в среднем 19\%), амилосубтилина на 2,5..6,8\% (в среднем 4,0\%), бишофита на 7,2... 13,4\% (в среднем 4,6\%). Бездефектных шкурок во всех группах также в основном было больше, чем в контрольной, особенно в группах с добавкой бишофита. Зачёт по качеству шкурок в опытах с ионолом был выше -до 8\%, дилудина - до 6\%, фенозана - до 4,2\%, глутамата натрия до $10 \%$, амилосубтилина и пектофоетидина - до 11 и 7,5\% соответственно, бишофита - до 12\%. В группах с кормовыми добавками площадь шкурок была выше - от 13 до 97 см2.

Для поддержания естественной резистентности животных и сохранения продуктивности в условиях снижения качества и питательной ценности кормов Лоенко Н.Н., Артюхова Н.С. (2002) предлагают антиоксидант феноксан. Применение феноксана в рационах забойного молодняка в период выращивания в дозах 2 и 4 мг/кг живой массы в сутки обеспечивает нормальный рост молодняка норок, повышает его сохранность на 4,0-6,5\%, что подтверждается более высокими показателями неспецифической резистентности и биохимическими показателями обмена веществ у зверей. 
Результаты исследований Новицкого А.П. (2002) свидетельствуют о том, что включение эхинолана-Б в рационы молодняка норок в летнийосенний период в дозах 50 мг на голову в сутки способствует повышению живой массы на 7,9\%, площади шкурки на 6,6\% и увеличению зачета по качеству на $7,8 \%$.

Мамаевой И.В. (2005) установлено, что «Биостим-К» способствует интенсификации роста зверей и способствует ускоренному созреванию зимнего волосяного покрова норок.

Биологически активный препарат «Фервистим» был испытан на молодняке норок (Перминов П.М., 2002). «Фервистим» - выделенная на зерновом сырье из виноматериалов уникальная микробная культура, продуцент белка и широкого спектра витаминов, незаменимых аминокислот, специфических полисахаридов, являющихся регуляторами многих процессов жизнедеятельности организма. Было установлено, что стимулятор при применении 10-ти дневными курсами в дозе 4 г на кг живой массы повышал массу тушек на 117 г, площадь шкурки на 0,74 дм² , зачет по размеру на 4,4\%, а зачет по качеству на $6,2 \%$.

Для профилактики и лечения гипотрофии щенков песцов Владимиров A.В. (2002) применял иммуномодуляторы тималин и его синтетический аналог - тимоген. Результаты исследований показали, что в подопытной группе все самки, кроме одной, благополучно ощенились. Выход на основную самку составил 10,0 щенков, в контроле - 9,1 щенка. В подопытной группе после щенения все щенки росли и развивались нормально (среди них не было гипотрофиков). При испытании с профилактической целью тиалина - тимогена получены аналогичные результаты.

Использование негормональных препаратов крезацина и мивала позволяет повысить воспроизводительную способность даже у молодых самок пушных зверей (Орлов П.П., Воронков М.Г., Дьяков В.М., 1989; Орлов 
П.П., Ситников С.В., 2002). Крезацин несколько более эффективен при введении его перед гоном (снижает пропустование у молодых самок), а мивал - при введении во вторую половину беременности (повышает жизнеспособность полученного молодняка, так и молодых самок).

Кормовой витаминный препарат «Мультивит», полученный методом микробного синтеза с использованием в качестве продуцента пропионовокислых бактерий, регулирует кроветворение, оказывает гепатозащитное действие, увеличивает выживаемость потомства, обладает свойствами анаболика. Этот препарат усиливает белковый обмен у зверей и нормализует функцию печени, живая масса норок после использования этого препарата увеличивается на 100-200 г, или на 5-10\%. Площадь шкурок

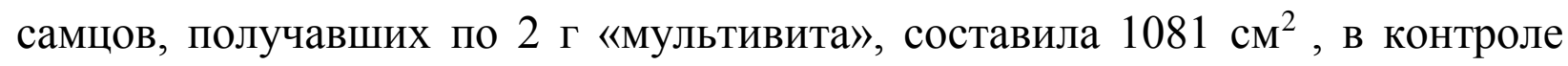
площадь шкурок составляла $1020 \mathrm{~cm}^{2}$, соответственно качество шкурок оценивалось в 113 и 109\%. Выход щенков на самку в сравнении с контролем был больше на 0,5-1,0.

Добавление пуриветина в корм самкам и растущему молодняку норок 3,5- и 10-дневными курсами соответственно по 0,17 мг/кг и 0,25 мг/кг способствует повышению молочности самок, сохранности молодняка (вдвое) и качества шкурковой продукции (зачет увеличивается на 10\%) (Балакирев Н.А., Кузнецов Г.А., 2006).

Как видно из приведенных литературных данных, введение в рационы различных биологически активных веществ положительно влияет на рост и воспроизводительную способность пушных зверей, улучшает качество получаемой продукции. Биологически активные вещества имеют широкий спектр действия и потенциальные возможности продуктивности пушных зверей могут быть раскрыты только при использовании различных стимуляторов и их применение является весьма перспективным.

\subsection{1. Механизм действия парааминобензойной кислоты (ПАБК)} Парааминобензойная кислота (ПАБК) является первичным ароматическим 
амином и была выделена в 1863 году. Получают ПАБК окислением пнитротолуола с последующим восстановлением п-нитробензойюй кислоты.

ПАБК представляет собой белое кристаллическое вещество, приобретающее при долгом хранении желтоватый оттенок. Она растворима в воде, спирте, плохо растворима в этаноле и эфире. Молекулярный вес (масса) 137. Температура плавления 186-187 ${ }^{\circ} \mathrm{C}$, выдерживает автоклавирование. ПАБК - химически стойкое вещество: не разрушается при кипячении в кислой и щелочных средах. Широко распространенный в медицинской практике препарат новокаин представляет хлористоводородную соль диэтиламиноэтилового эфира ПАБК.

$\mathrm{COOH}$

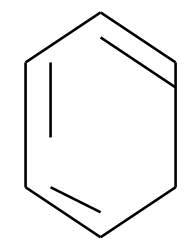

Парааминобензойная кислота

NH2

В соответствии с классификацией одних исследователей ПАБК следует отнести к витаминам (БЭС, 1986), в соответствия с представлениями других, она - витаминоподобное соединение (Филиппович Э.Г.,1985).

В медицине широко используются аналоги парааминобензойной кислоты, обладающие антагонистическим действием, называемые сульфаниламидами. Они, являясь структурными аналогами парааминобензойной кислоты, могут конкурентно замещать ее в ферментных системах микробов с последующей остановкой роста и размножения. Однако не все микробы нуждаются в этом витаминоподобном веществе (Попков Н.А., Фисинин В.И., Егоров И.А., Пономаренко Ю.А., Шаршунов В.А., Пономаренко В.С., 2005).

Парааминобензойная кислота (витамин Н1), широко распространена в природе. Она содержится в животных и растительных тканях, в пищевых продуктах, в микроорганизмах. В значительных количествах ПАБК 
обнаружена в печени, почках, молоке, грибах, дрожжах, рисовых отрубях. ПАБК является ростовым фактором многих микроорганизмов (в том числе населяющих кишечник животных и человека), то есть является, безусловно, необходимым витамином для нормальной жизнедеятельности млекопитающих. Она входит в состав весьма важного витамина - фолиевой кислоты и различных ее дериватов (Збарский Б.И., Иванов И.И., Мардашев С.С., 1965). Известно, что ПАБК участвует в синтезе фолиевой кислоты, необходимой для существования значительного числа микроорганизмов.

Woods D.D. (1940) установил, что ПАБК является сильным антагонистом при действии сульфамидных препаратов на бактерии. Антагонизм между структурно родственными соединениями (ПАБК и сульфаниламидами) носит "конкурентный" характер за обладание ферментами, входящими в биологически активную энзимную систему. Происходящие при этом реакции имеют обратный характер.

Дальнейшее изучение сущности энзиматической реакции с участием ПАБК как коэнзима показала, что некоторые пурины (аденин, гуанин, ксантин), а также тимин и отдельные аминокислоты (метионин, лизин, серин) обладают определенным антисульфаниламидным действием. Некоторые из перечисленных веществ частично или полностью в состоянии заместить в качестве ростового фактора ПАБК. Последующие наблюдения (Рысс С.М., 1963), укрепили высказанное положение и доказали, что все эти вещества являются продуктами реакции, происходящих с участием ПАБК. Сульфаниламиды, вытесняя ПАБК, угнетают образование пуринов, тимина, аминокислот. Таким образом, становится понятной ведущая роль ПАБК в синтезе рассматриваемых веществ.

Биологическая роль ПАБК в качестве кормовой добавки заключается в том, что это соединение с помощью кишечной микрофлоры включается в состав молекул фолиевой кислоты (витамин Вс), которая в свою очередь, служит предшественником тетрагидрофолиевой кислоты (ТГФК). ТГФК 
служит кофактором целого ряда ферментов азотистого обмена. В частности, ТГФК в качестве кофермента совершенно необходима для синтеза пуриновых оснований, входящих в состав нуклеиновых кислот, макроэргических нуклеотидов и значительного количества коферментов, в том числе КоА, НАД, ФАД.

Коферментные функции парааминобензойной кислоты не установлены, хотя она и обладает широким спектром физиологического действия на организм, являясь составной частью фолиевой и фолиновой кислот. ПАБК способствует синтезу пуринов и пиримидинов, а следовательно, РНК и ДНК. Она оказывает влияние на обмен некоторых биогенных аминов (Попков Н.А., Фисинин В.И., Егоров И.А., Пономаренко Ю.А., Шаршунов В.А., Пономаренко В.С., 2005).

По утверждению Sang E.N, King R.C. (1964) парааминобензойная кислота через фолиевую кислоту, в состав которой она входит, контролирует синтез генов (нуклеиновых кислот).

Фолиевой кислотой наиболее богаты продукты растительной природы. Очень высока потребность в фолиевой кислоте, а, следовательно, и в парааминобензойной кислоте у молодняка сельскохозяйственных животных.

Экспериментально доказано, что ПАБК тормозит энзиматический распад синтетического эстрогена. Подобное торможение она может вызвать также и в отношении адреналина, тироксина.

Помимо уже известных свойств витаминов открыто еще одно свойство антимутагенность, то есть способность устранять мутации в организме, вызываемыми ионизирующим излучением или канцерогенными. Высокой антимутагенной активностью обладают витамины А, C, В. Антимутагенное действие, свойство ПАБК было открыто в экспериментах на бактериальной клетке в отделе химической генетики ИХФ АН СССР. В соответствии с первоначальным предположением, антимутагенная активность ПАБК, была 
обусловлена ее влиянием на скорость и точность процессов репарации ДНК в бактериальной клетке (Алекперов У.К., 1989).

Одним из объяснений механизмов стимуляционного действия ПАБК может быть индуцированный его рост клеточных перегородок, путем инактивации соответствующего репрессора, в тех "многоядерных" бактериальных клетках, которые составляют опытную бактериальную культуру в логарифмической фазе роста, приводя, таким образом, к возникновению 2-4-8 клеток из одной, что в норме без ПАБК, не реализуется.

Предположения, что с помощью ПАБК можно достичь значительного снижения мутационного эффекта и повышения жизнеспособности организма, были проведены на бактериальной клетке и на Crepes capillaris (Белецкий Ю.Д., Прикотенко Э.Я., Сизова Л.И., 1986, Григорьева Н.В., Иофа Э.Л., 1982, 1986).

В серии экспериментов, проведенных на кишечной палочке, показано, что ПАБК, являющаяся предшественником фолиевой кислоты, снижает мутагенный эффект $N$-нитрозодиметилмочевины (HМM) УФ - и гаммаоблучения. Использование в работе штаммов Escherichia coli, различающихся активностью ферментных систем репараций повреждений ДНК, позволило авторам связать антимутагенную активность ПАБК с его влиянием на ферментативные процессы. В условиях индукции мутаций НММ антимутаген (ПАБК) снижал уровень мутабильности более чем в 25 раз при одновременном резком повышении выживаемости (Васильева С.В., 1984).

Также высока эффективность ПАБК в случаях, когда мутации вызывались УФ-излучением. Наибольшее же снижение темпов мутирования (до 600 раз) наблюдалось при изучении влияния ПАБК на мутации, индуцированные гамма-лучами. При этом антимутагенное действие ПАБК специфично и почти не наблюдается на штаммах, дефектных по ферментам репарации. 
В литературе описан эффект индукции множественных положительных модификаций витамина п-аминобензойной кислоты (ПАБК) на дрозофиле и других объектах (Ефремова Г.И., Рапопорт И.А., Прокофьева Г.Н., 1986). В настоящее время известно, что основная роль ПАБК в метаболизме клетки сводится к ее участию в построении фолиевой кислоты. Последняя катализирует превращение и перенос активированных одноуглеродных остатков, которые используются в синтезе пуриновых и пиримидиновых оснований нуклеиновых кислот и некоторых аминокислот (серина, метионина). Показано, что ПАБК радикально отличается своим репарагенным действием от некоторых ферментов, считавшихся до недавнего времени единственно участвующими в репарационном процессе. ПАБК, являясь репарогеном, увеличивает во много раз уровень спонтанной репарации. Это оправдывает применение термина "репароген" как обозначение фактора, влияющего на интенсивность репарации. Можно полагать, что репарогенез является частным случаем антимутагенеза, тем более что У.К.Алекперов (1989) антимутагены характеризует как агенты, предотвращающие нарушения процессов ДНК - репликации и ДНК репарации.

Являясь физиологическим веществом, а именно витамином Н1, ПАБК способна взаимодействовать с генетическим аппаратом. Способность ПАБК противодействовать возникновению мутаций на собственном репарогенном уровне не распространяется на морфологические модификации, индуцируемые другими агентами, ненаследственной изменчивости. Это подчеркивает специфичность репарогенного механизма, свойственного ПАБК (Рапопорт И.А., Дроздовская Л.Н., Машина С.Ю., 1982).

Выявлено свойство ПАБК влиять на ферменты нуклеинового обмена. Исследования выявили, что ПАБК в соответствующих концентрациях не только полностью восстанавливает исходную активность РНК-азы истекшего срока годности, но и значительно повышает ее. В концентрации $0,1 \times 10(-2)$ M 
ПАБК поднимает относительную активность фермента на $80 \%$, то есть за пределы исходной активности свежего препарата (Кожевникова Н.А., Путрина И.Д., Иваницкая Е.А., 1986).

Исследования Н.А.Кожевниковой, И.Д.Путриной, Е.А.Иваницкой (1986) показали, что ПАБК активирует фермент растительной протеиназы из Carica papaya. Как и на бактериальной клетке установлена зависимость величины эффекта от применяемой концентрации ПАБК.

Активность ПАБК на живой организм была показана еще до идентификации ее в качестве витамина (Рапопорот И.А., Дроздовская Л.Н., 1978).

Парааминобензойная кислота тормозит развитие экспериментального холестеринового атеросклероза, оказывает отчетливый лечебный эффект при экспериментальном инфаркте миокарда (способствует распаду холестерина в печени). ПАБК эффективна при мышечных кровотечениях, стимулирует эритропоэз, нормализует липидный и белковый обмены (Попков Н.А., Фисинин В.И., Егоров И.А., Пономаренко Ю.А., Шаршунов В.А., Пономаренко В.С., 2005).

На лабораторных животных установлена способность парааминобензойной кислоты с комплексом витаминов (биотин, фолиевая кислота, рибофлавин) частично заменить аскорбиновую кислоту (Ю.С.Шкункова, П.С. Авраменко, В.Е. Краско, 1971). Дальнейшие опыты показали, что получавшие ПАБК крысы были способны в большей степени переносить кислородное голодание. Исключение парааминобензойной кислоты из диеты крысы привело к нарушению лактации у самок (Э.Г. Филипович, 1985).

В Швеции, Дании и Финляндии комплекс витаминов (в том числе и ПАБК) применяется в корм норкам в различные периоды (подготовка к гону, гон, беременность, лактация, рост молодняка) как источник белка (Hoffmann F.,1971).

С целью изучения стимулирующего влияния различных микродоз 
ПАБК на отстающих в росте щенят песцов на песцовой бригаде зверосовхоза «Салтыковский» Московской области были проведены исследования. Свечиным Ю.К., Егоровой А.Г. (1989), Новиковой Н.Н., Эрнст Л.И., Романенко Г.М. (1999), Свечиным Ю.К., Смирновым Ю.А. (2002) установлено, что значительный больший эффект компенсации недоразвития щенят песцов был получен при введении им в корм 1,0 мг парааминобензойной кислоты на 1 кг живой массы на 5-й и 40-й день их жизни. К 4-месячному возрасту щенята песцов, получавшие 0,5 мг ПАБК на 1 кг своей живой массы, имели живую массу 5,02-5,73 кг, при получении же 1,0 мг - 5,18-5,73 кг, при получении же 1,0 мг - 5,18-5,94 кг и при скармливании 1,5 мг - 4,08-5,68 кг. По сравнению с контрольными, все опытные щенки имели и большую длину тела. Морфологические показатели крови молодых песцов свидетельствуют о том, что добавка ПАБК к корму не вызывает глубоких изменений в ее составе. Количество эритроцитов, лейкоцитов и процент гемоглобина у этих зверей во всех группах находились в пределах нормы. Биохимические показатели крови свидетельствуют также о повышении содержания общего белка и гаммаглобулиной фракции, особенно у особей, получавших 1,0 мг этого препарата на 1 кг живой массы. При бонитировке контрольных и опытных песцов было установлено, что парааминобензойная кислота улучшало такие показатели как размер и телосложение у самцов и самок, и не оказывало отрицательного влияния на качество и окрас волосяного покрова. Результаты бонитировки песцов подтверждаются и сортировкой их шкурок. Введение микродоз парааминобензойной кислоты в корм щенкам песцов повышает их сохранность на 8,48...12,5\%. К 4 месяцам щенки песцов имеют большую длину тела, чем контрольные. При введении им этого препарата достигается значительно больший эффект компенсации недоразвития, чем при введении других препаратов (Гегамян Н.С., Новикова Н.Н., Егорова А. Г., Романенко T.M., 2001). 
На основании проведенных исследований производству было предложено использовать парааминобензойную кислоту с кормом, как стимулятор роста для отстающих в развитии песцов в количестве 1,0 мг на 1 кг живой массы зверей начиная с 40-дневного возраста их жизни (один раз в сутки, через день, всего шесть раз).

Как видно из приведенных литературных источников, введение в рацион оптимальных доз парааминобензойной кислоты положительно влияет на физиологическое состояние, рост, воспроизводительную способность животных, улучшает качество продукции.

\subsection{2. Механизм действия янтарной кислоты (ЯК)}

Янтарная кислота - это побочный продукт янтарного производства. Она используется в фармакологии как универсальный биостимулятор естественного происхождения - повышает иммунитет организма человека.

Янтарная кислота - это универсальный биостимулятор и неотъемлемый компонент всех живых организмов. Она вырабатывается в клетках человека и отвечает за энергетический обмен, а ведь именно энергетические нарушения ведут к снижению иммунитета и, как следствие, к возникновению различных заболеваний. Потому дефицит янтарной кислоты, возникающий при физических, умственных и эмоциональных нагрузках, необходимо постоянно пополнять.

Янтарная кислота получается в процессе биологического синтеза, это безвредное вещество, обладающее особыми полезными качествами: она усиливает энергетический обмен в клетках тканей, оказывает положительный эффект даже при небольших дозах. Дефицит янтарной кислоты приводит к ухудшению работы всего организма;

Янтарную кислоту относят к категории «умные лекарства». Опыт исследования янтарной кислоты показывает наличие у препарата многих физиологических эффектов. Наиболее важным из качеств янтарной кислоты является увеличение энергетического обмена в клетках. Не обращая 
внимания на здоровые клетки, препарат быстро проникает в клетки, где остро чувствуется нехватка энергии. В медицине янтарная кислота применяется при атеросклерозе сосудов. В медицине янтарная кислота применяется при атеросклерозе сосудов головного мозга, ишемической болезни сердца (стенокардии), сахарном диабете, а также при различных заболеваниях для быстрейшего выздоровления. Почти полвека назад в янтарной кислоте обнаружили новое свойство - защита организма от радиации. Более того, янтарная кислота обладает также общеукрепляющим и оздоровляющим эффектом.

Янтарная кислота в положительном смысле является допингом, хотя не попадает в список запрещенных для профессиональных спортсменов препаратов. Она мобилизует силы спортсмена, повышает его выносливость, снимает болевые ощущения в мышцах.

Недостаток янтарной кислоты - она отражается на эффективности иммунной системы: организм становится не в силах сопротивляться неблагоприятным воздействиям окружающей среды, возникают нарушения в работе отдельных систем и, в первую очередь, мозга.

Прием препарата с профилактическими целями или при первых признаках заболевания поможет организму легко справиться с инфекцией и приобрести иммунитет.

Янтарная кислота - это природное соединение, содержащееся в небольших количествах в различных продуктах питания и вырабатываемое каждой клеточкой организма человека, животных и растений. Это средство является важнейшим веществом, участвующим в образовании энергии в организме. С недавнего времени она стала доступна в виде таблеток. Сейчас это один из наиболее эффективных, безвредных и доступных для каждого препаратов. Янтарная кислота является естественным веществом присутствует во всех организмах. Оказывает мощнейшее оздоровительное действие, не вызывая побочных эффектов и привыкания. Причин такого 
воздействия множество, но есть основные.

Янтарная кислота стимулирует выработку энергии в клетках. C возрастом, кроме прочих нарушений, клетки организма начинают терять способность к выработке энергии. Как следствие, организму не хватает энергии для нормального обеспечения многих функций, а это ведёт к увяданию организма и быстрому старению. Соединение, которое даёт энергию - это АТФ (аденозинтрифосфат). Янтарная кислота как раз и способствует выработке АТФ. Как следствие, янтарная кислота является мощным стимулятором выработки энергии и стимулятором многих функций организма, обладает исключительной восстановительной способностью.

Янтарная кислота усиливает клеточное дыхание, способствует усвоению кислорода клетками. Например, прирост скорости потребления кислорода клетками печени при добавлении в корм и пищу янтарной кислоты увеличивается в 60 раз. Янтарная кислота обезвреживает свободные радикалы. Обладает мощным антиоксидантным свойством.

Как говорилось не раз, в процессе жизнедеятельности организма образуются агрессивные формы кислорода, которые окисляют или разрушают клетки, вызывая болезни (рак, инфаркт, и т.п.), старение и смерть. Янтарная кислота способна эффективно обезвреживать свободные радикалы.

В целом, воздействие янтарной кислоты на организм огромно. Она: а) выраженно улучшает работу большинства органов (мозга, сердца, почек, печени и др.). б)препятствует возникновению опухолей и тормозит рост уже возникших. в)укрепляет иммунитет. г)тормозит воспалительные процессы (нормализует содержание гистамина и серотонина). д)повышает микроциркуляцию в органах и тканях. е) активирует ряд важнейших ферментов.

За счёт перечисленных эффектов янтарная кислота существенно продлевает жизнь, защищает от многих заболеваний, а некоторые из них вылечивает. Всё это доказано в многочисленных экспериментах. Янтарная 
кислота увеличивает выживаемость животных при воздействии на них многих, обычно смертельных, факторов.

Янтарная кислота- это естественное вещество, которое присутствует в организме, вырабатывается им. Поэтому она при приёме внутрь не вызывает привыкания и не вызывает особых побочных эффектов.

Янтарная кислота является звеном в цикле трикарбоновых кислот Кребса и одним из активаторов сукцинатдегидрогеназы (СДГ) - первого фермента сук-цитатоксидазной системы митохондрий, где протекает основная часть реакций энергетического обмена организма (Кондрашова М.Н., Григоренко Е.В., 1985).

По последним научным данным, осуществление физиологических функций обеспечивается избирательным увеличением вклада в дыхание именно сукцината, а не общим повышением окисления всех субстратов через цикл трикарбоновых кислот. Этот механизм в организме запускается катехоламинами и связан с активацией ряда процессов более быстрого образования янтарной кислоты, чем цикл Кребса, в частности, его шунтирование аспарат- и аланинаимнотрансферазами (быстрый цикл окисления или цикл янтарной кислоты). Введение янтарной кислоты и её производных в организме стимулирует увеличение содержания норадреналина и адреналина в тканях, что, в свою очередь, активирует образование и окисление янтарной кислоты в митохондриях. Янтарная кислота смягчает все виды технологических стрессов у сельскохозяйственной птицы, положительно влияет на воспроизводительную функцию и молочную продуктивность животных, жизнеспособность, здоровье и рост молодняка (Кожевникова Л.К., Мелдо Х.И., Унжаков А.Р., 1991; Лузбаев К.В., Найденский М.С., Зубалин С., 1995; Узенбаева Л.В., 1991). У подопытных лабораторных животных получавших сукцинат (с питьевой водой) в течение двух месяцев, установлено, что под его действием в печени и скелетных мышцах подопытных животных 
содержание белка увеличилось в 1,3 раза по сравнению с контрольными и содержание в тех же органах липидов, глюкозы и гликогена понизилось в 1,3 раза. Отмечалось и повышение в крови уровня гликогена (в 1,4 раза), снижение количества белка, холестерина и глюкозы (Осташкова В.В., Судакова Н.М., Яковлева М.Н.и др., 1991).

Установлено, что янтарная кислота и ее соли оказывают благотоворное влияние на организм, обладают антигипоксическим и нейротропным действием, нормализует энергетический обмен и общее физиологическое состояние, усиливают процессы синтеза в различных органах в условиях патологии и действия экстремальных факторов (Бобков Ю.Г., Кузнецова Г.А., Клейменова Н.Н., 1984; Григоренко Е.В., Кондрашова М.Н., 1987).

При изучении влияния янтарной кислоты на физиологические и биохимические процессы продуцента S. Levoris, было установлено, что в её присутствии происходит интенсификация субстратных потоков, проходящих через клетку. Это увеличивало удельную скорость выращивания культуры. Опираясь на полученные результаты, авторы предположили, что стимулирующее действие сукцината не является специфичным для леворина. Это подтверждается влиянием янтарной кислоты на самые разные живые организмы (Кузьмин В.Н., Цыганков В.А., Василенко С.М., 1989).

Янтарная кислота достаточно хорошо растворяется в воде. Внутривенно введённая животным она быстро выводится из организма. Используется для подкисления пищи, широко применяется медиками (дитилин, левомицетина сукцинат натрия, преднизолонгемисукцинат, пуфемид, хинотилин). Янтарная кислота и её соли обладают адаптогенной способностью и оказывают антигипоксическое, антиоксидантное и нейротропное действие, нормализует энергетический и углеводный обмены, общее физиологическое состояние организма, усиливает процессы синтеза в различных органах при патологии и в условиях действия экстремальных факторов, устраняют метаболический ацидоз (Мудрый И.Н, 1978, 
Николаенко В.П., 1988; Кондрашова М.Н, 1991).

Янтарная кислота повышает защитные функции организма после тяжелых заболеваний и в период восстановления после травм, инсультов, хронических интоксикаций, а также устраняет последствия стрессов и повышает физическую и умственную способности, снижает алкогольную и наркотическую интоксикацию, снижает головную боль, корректирует нарушения памяти, связанные с ухудшением мозгового кровообращения (Фурдуй Ф.И., 1990, 1992).

В работе Бормашевой Н.И. (1983) установлено, что под действием янтарной кислоты происходит нормализация кислотно-щелочного соотношения, значительно или полностью уменьшается ацидоз, увеличивается ёмкость буферных систем крови. Предварительное введение гамма-оксимасляной и янтарной кислот при моделируемой ишемии тканей мозга нормализует показатели дыхательной функции клеток мозга (Волкова С.П., Кузнецов В.И., Кондрашова М.Н., 1987; Григоренко Е.В., Кондрашова M.H, 1987). Антиспазматическим действием обладают также и препараты янтарной кислоты (сукцинат натрия и калия). Они эффективны при лечении бронхиальной астмы (Кшановский С.А, и др., 1982). Отмечено благотворное влияние янтарной кислоты на коронарное кровообращение и сократительную функцию сердца (Шахматов М.М., Севастьянов С.И., 1974; Богацкая Л.Н., Козинец Г.Н., 1980; Саарма Ю.М.,1973). Длительное применение сукцината натрия способствует нормализации структуры и функций органов, устраняя морфофункциональные расстройства капилярной сети внутренних органов (Чумаченко В.Е.. Высоцкий А.М., Сердюк Н.А. и др., 1988).

В опытах на лягушках, кроликах и норках было доказано, что янтарная кислота и её натриевая соль оказывают возбуждающее влияние на моторную функцию желудка и восстанавливают способность истощенной слизистой оболочки желудка секретировать соляную кислоту. Они 
способствуют восстановительным процессам в поврежденной слизистой оболочке желудка (Унжаков А.Р., 1993; Околелова Т.Н., 1992).

Янтарную кислоту в сочетании с некоторыми лекарственными средствами применяют для усиления их действия или снятия токсических побочных эффектов. Натриевую соль янтарной кислоты используют для выведения из наркоза и коматозного состояния при отравлении морфином или барбитуратами (Никулин А.А., Храпова С.И., Тебякина Е.А., 1988). Значительно повышает устойчивость организма к острому охлаждению и к гипертермии предварительное введение янтарной кислоты (Бобков Ю.Г., Виноградов В.М., Смирнов А.В., 1981, Филатова Г.Ф., Кузнецова Г.А., Бобков Ю.Г, 1986).

Установлено, что янтарная кислота и её соли обладают способностью повышать выносливость при физических нагрузках человека и животных, имеют защитное действие при циркуляторно - дыхательной гипоксии (Соколов И.К, Каплан Е.Я., 1981; Бобков Ю.Г., Кузнецова Г.А., Клейменова H.H., 1984).

Янтарная кислота и её соли, будучи естественными легкоокисляющимися, нетоксичными метаболитами, повышают устойчивость организма к рентгеновскому излучению. Потребление мышами сукцината натрия повышало устойчивость кроветворной системы $к$ сублетальному рентгеновскому облучению, стимулировало увеличение массы тела, тимуса и селезёнки мышей (Штурм Р., Ивницкий Ю., Проскуряков С.Я. и др., 1988). С помощью янтарной кислоты нормализуется физиологическое состояние организма в старости. В опытах на старых крысах её ежедневное введение в дозе 50 мг/кг в течение 6 дней способствует нормализации окислительного фосфорилирования и синтеза фосфаналпирувата в печени (Косенко Е.Н., Коминский Ю.Г., Кондрашова M.H, 1981).

Влияние янтарной кислоты на продуктивность сельскохозяйственных 
животных параллельно с применением других биологически активных веществ, в качестве которых использовались фракции электрохимически активированных растворов (аналит и католит), изучал Халимов Х.К. с соавторами (1994). Их целью было выявление возможности явления синергизма действий на организм животных как янтарной кислоты, так и фракций данных растворов. Исследования показали, что янтарная кислота, растворенная в католите, способствовала повышению среднесуточного прироста на 23 г по сравнению с контролем. Если препарат растворить в анолите, то он более эффективен, так как среднесуточный прирост животных был выше контроля на 62 г или на 13,2\% (Халимов Х.К., Лиакумович А.Г.,. Закирьянов Ш.Х и др., 1994).

Применение янтарной кислоты животным способствует повышению энергии роста млекопитающих разных видов. У кроликов при однократном подкожном введении раствора 1:1000 сукцината в дозе 0,08 мл на 1 кг живой массы среднесуточный прирост повышался на 13 г, а у кроликов, получавших вдвое большую дозу препарата - на 45 г (Шахматов М.M., Севастьянов С.И., 1974). У норок также отмечено значительное увеличение среднесуточного прироста при даче им с кормом янтарной кислоты в дозе 0,08 мг/кг живой массы в течение 6 месяцев (Унжаков А.P., 1993). Сукцинат у лактирующих самок норок нормализует активность ферментов крови, увеличивает аэробную фракцию пролактина (Березина О.В., 2000).

Как показывает анализ литературных данных, янтарная кислота смягчает все виды технологических стрессов у животных, оказывает многостороннее действие на организм, активизируя обменные процессы. Янтарная кислота положительно влияет на воспроизводительные функции животных и их продуктивность.

\subsection{3. Механизм действия сукцината хитозана}

Хитозан - является производным хитина - результат обработки хитина в жестких условиях раствором щелочи позволяет заместить ацетильные 
группы хитина аминогруппами. Он является В-(1-4)-2-амино-2дезокси-Дгликополисахаридом, т.е. аминополисахаридом, полученным при удалении ацетильной группы из положения $\mathrm{C}_{2}$ в хитине. Как щелочной полисахарид обладает возможностью угнетать желудочную кислоту и оказывать антиязвенное действие. Он также влияет на содержание жира и холестерина в крови, обладает способностью агглютинировать клетки. Хитозан относится к широко распространенной в природе и составляющей основную массу органического вещества на Земле группе полисахаридов. К неоспоримым достоинствам хитозана относится его совершенная безопасность для человека и окружающей среды. В природных условиях он распадается полностью. Экологически чист. Благодаря своим биологически активным веществам хитозан нашел применение в медицине, сельском хозяйстве, пищевой, текстильной и атомной промышленности, в косметологии и др.(Жоголев К.Д., Цыган В.Н., Никитин В.Ю., 2000; Жоголев К.Д., Никитин В.Ю., Цыган В.Н., Егоров В.Н., 2000).

В сельском хозяйстве хитозан применяется как средство лечения и профилактики кишечных расстройств у молодняка сельскохозяйственных животных, как носитель ветеринарных лекарственных средств, благодаря тому, что может проходить не разрушаясь, через многакамерный желудок жвачных животных (Албулов А.И., Самуйленко А.Я., Фоменко А.С., Шинкарев С.М., Пилипейко Е.А., Трунов А.М., 2000)..

Существенным является то, что хитозан - это хорошее росторегулирующее вещество. Росторегулирующая активность хитозана объясняется тем, что при разложении его образуется азот, который легко усваивается, находясь в непосредственной близости от объекта воздействия.

Полисахариды выполняют в живых организмах весьма важные функции. По биологической функции полисахариды делят на конструктивные (например, целлюлоза, хитин), запасные или энергетические (крахмал, гликоген, эремуран) и физиологические активные (гепарин, полисахариды ве- 
ществ группы крови). В особую группу выделяют бактериальные полисахариды. Многие полисахариды обладают высокой биологической активностью, например, гиалуроновая кислота участвует в минеральном обмене и регулирует проницаемость тканей и т.д. Полисахариды обладают антигенными свойствами. Эти свойства полисахаридов в высокой степени зависят от их молекулярной структуры. Имеются сведения, что препараты, представляющие из себя полисахариды способны оказывать иммуномодулирующее действие, вызывать десенсибилизирующий эффект, кроме того, отмечают анафилактогенную активность полисахаридов.

Хитозан впервые был получен в 1859 году C. Rouget. Исследования развивались очень медленно, привлекая внимание сначала биологов, а затем химиков-органиков и были сосредоточены во Франции и Германии. С получением хитозана стало ясно, что он может иметь практическое значение, и его начали интенсивно исследовать в разных странах, в том числе и в России.

Хитин и хитозан представляют собой длинноцепочечные молекулы с большой молекулярной массой, доходящей до нескольких миллионов Дальтон, по своему химическому составу и строению они идентичны, за одним исключением: в каждом кольце молекулы хитина у второго атома углерода расположена ацетоамидная группировка, а в хитозане на этом месте аминогруппа. Хитозан - это хитин, в котором при обработке щелочью (деацетилирование) удалена ацетильная группа, а на этом месте находится аминогруппа. Молекула хитина всегда содержит небольшое количество первичных аминогрупп, а молекула хитозана амино-ацетильные группы, количество которых зависит от условий получения полимера.

Хитозан обладает высокой плотностью положительных зарядов, совместим с сильными катионами, высокой сорбционной способностью, химической, биологической и радиационной стойкостью, образует сильные прозрачные пленки, растворим в разбавленных органических и некоторых 
неорганических кислотах, образуя растворы различной вязкости, устойчивые к высоким температурам и разрывам. Он образует гель с многовалентными анионами, обладает прекрасной осаждаемостью хлопьев, поглощает и удерживает ионы металлов. Хитозан нетоксичен, является хорошим флоккулянтом, эмульгатором, загустителем и структурообразователем, обладает ранозаживляющей способностью, антикоагулянтной, антитромбической, бактерицидной и противоопухолевой активностью, способностью к волокно- и пленкообразованию. Вследствие присутствия в каждом звене по аминогруппе, свойства хитозана существенно отличаются от свойств, присущих хитину (Актуганов Г.Э., 2000; Агее в Е.П., Вихорева Г.А., Матушкина Н.Н., Пчелко О.М., Гальбрайх Л.С., 2000).

Сукцинат хитозана представляет собой полимерное вещество, состоящее из соединенных друг с другом В-1,4 - гликозидной связью мономерных звеньев. Относительное содержание каждой из указанных мономерных структур в продукте должно быть следующим (\%): А - не более 20, Б - не более 20, В - не менее 65. Сукцинат хитозана представляет собой порошок без запаха, растворимый в воде, белого цвета, иногда с розовым, кремовым или сероватым оттенком, практически не растворимый в 96-\%-ном этиловом спирте и ацетоне. При соединении хитозана с янтарной кислотой (сукцинат хитозана) усиливаются иммунорегулирующие, иммуностимулирующие и антиоксидантные свойства янтарной кислоты, полученный продукт водорастворимый с высокой биологической активностью.

Известно свыше 50 направлений использования хитозана в различных отраслях промышленности и медицине.

Неоспоримо роль сукцината хитозана в повышении неспецифической резистетности организма к действию неблагоприятных факторов среды (Цыган В.Н., Жоголев К.Д., Никитин В.Ю., 2000).

Ацилированные производные хитозана входят в состав косметических средств, а также фармацевтических композиций, используются для 
приготовления дезодорантов и агглютинирующих агентов. Из хитозана получают мембраны, которые предложено использовать как искусственные мембраны для почек. Они обладают высокой механической прочностью и проницаемостью для мочи и креатина, и в то же время они непроницаемы для белков сыворотки. Большое преимущество хитозановых мембран по сравнению с мембранами, полученными из других полимеров, состоит в том, что они препятствуют прохождению в кровь токсических металлов.

Производные хитина находят применение как антикоагулянты крови, как заменители очень дорогого гепарина.

В фармацевтической промышленности хитин также используется для создания биоразрушаемых мембран лекарственных форм (тетрациклин, неомицин и др.). Хитин и его мономеры способствуют более быстрому заживлению ран. Установлено, что рост раковых клеток можно специфически ингибировать положительно заряженными полисахаридами.

В последние годы хитин и его производные начинают широко применяться в биотехнологии как специфические сорбенты и носители для иммобилизованных ферментов (а - химотрипсина, кислот фосфатазы, диастазы и др.) и клеток. Высокая сорбционная способность хитина и его производных находит применение для выделения металлов (цинка, никеля, меди, кадмия, урана) из водных растворов, что особенно важно для очистки сточных вод, являющихся отходом индустриальных производств.

Полученные данные свидетельствуют, что сернокислый эфир хитозана является антикоагулянтом, имеющим не только значительную структурную гомологию с гепарином, но и сходный механизм действия, сернокислый эфир хитозана преимущественно тормозит свертывание крови по внутреннему пути, катализируя инактивацию тромбина АТ.

Анализ литературных данных свидетельствует о перспективности применения хитина и хитозана в микробиологической промышленности, в частности в области создания непрерывной технологии каталитических 
превращений веществ с использованием иммобилизированных ферментов, где хитин и хитозан используются в качестве носителя.

Применение хитина и хитозана дает положительные результаты при очистке ферментов и других биологических активных соединений.

Гелевые сорбенты, полученные на основе хитозана, существенно расширяюет область хроматографической очистки и выделения биоматериалов.

Создание полимерных мембран широкого спектра действия, флокулянтов для концентрирования культуральных жидкостей и активного ила, микробиологических сред на основе хитина - вот далеко неполный перечень возможностей этого уникального класса полимеров.

Хитин нашел применение и в пищевой промышленности. Гидролизат хитина предложено использовать как составной компонент детского питания и как стабилизатор соков, разработана технология получения соусов и приправ на основе рыбных бульонов, содержащих хитозан в качестве эмульгатора.

По литературным данным проведенная гигиеническая оценка хитозана в условиях длительного эксперимента показала, что хитозан не вызывает нежелательных изменений в состоянии подопытных животных. Установлено положительное влияние на липидный обмен, в частности, на соотношение фосфолипидов в крови, липидных и азотистых фракций в печени. Имеются сведения о влиянии сульфата хитозана на развитие экспериментального атеросклероза.

Хитин и его производные (частично деполяризованный и $\mathrm{N}$ ацетилированный аналоги), полученные из оболочек ракообразных, вызывают ускоренное заживление ран и используются для приготовления коллоидных растворов для инъекций, шовного материала, бинтов и т.д. Эффективность их сохраняется при комбинировании с аскорбиновой кислотой, солями цинка, антибиотиками и сульфаниламидными препаратами. 
По данным косметологических исследований, сукцинат хитозана не обладает раздражающим, аллергирующим действием и рекомендован для использования в косметических средствах в концентрациях от 0,1 до 0,5\% (гигиенический сертификат №2-809 от 08.09.93).

Данные, полученные в биологических тестах Александровой В.А. (1999), показывают, что в результате направленной модификации хитозана происходит значительное (до 92\%) усиление антимутагенной (при гаммаизлучении) эффективности полимерной системы.

Из литературных источников известно, что внесение хитозана в почву оказывает благоприятное воздействие на экологическую обстановку, стимулирует развитие хищных и паразитических грибов, уничтожает личинок нематод и их яйца, обладает иммуностимулирующим действием на растение (Иванова И.В., 1971; Тютерев С.Ч., Якубчик М.С., Тарлаковский С.А., 1995; Удалова В.Б., Быканова В.Р., Корнакова Н.Н., 1995; Удалова В.Б., Селиверстов А.Ф., Ершов Б.Г., 1999).

По данным Петрова В.А., Тарасенко Г.А. (1999), хитозан из панциря камчатского краба повышает мышечную работоспособность. Отмечена тенденция увеличения под его влиянием содержания общего белка сыворотки крови и белковых фракций. Установлено положительное влияние хитозана на состояние обменных процессов в печени и ее морфологическую структуру. Улучшилась фильтрационная способность почек. Выявлено антисклеротическое действие хитозана.

Албулов А.И., Самуйленко А.Я., Шинкарев С.М. (2000) описали возможность использования хитозана при лечении и профилактике желудочнокишечных заболеваний животных. Исследованиями установлено, что хитозан обладает выраженной иммуностимулирующей активностью.

Исследованиями Балицкого К.П., Векслера И.Г. (1977), Варламова В.П., Стояченко И.А., Буданова М.В. (1997), Коваль Ю.Ф., Жоголева К.Д., Никитина В.Ю., Буланькова Ю.И. (1992) установлено, что хитозан обладает 
выраженной иммуностимулирующей активностью.

Выявлено и изучено противовирусное действие препаратов хитозана на модели гриппозной инфекции у мышей. Хитозан при введении животным как в момент заражения вирусом гриппа, так и за 24 ч до заражения им способствует увеличению выживаемости подопытных животных и более легкому течению у них гриппозной инфекции. Выживаемость мышей при профилактическом введении препарата увеличивалась в 3-4 раза, а при интраназальном введении вместе с вирусом - в 2,0-2,5 раза (Шинкарев С.М., 2001).

В опытах на лабораторных животных (мышах различных линий) установлено, что хитозан оказывает иммуностимулирующее действие, вызывая 2-10-кратное увеличение силы иммунного ответа на эритроциты барана. Введение хитозана мышам различных линий приводит к относительному нивелированию генетических различий в силе иммунного ответа на эритроциты барана (Жоголев К.Д., Никитин В.Ю., 1998).

Хитозан увеличивает количество лимфоцитов селезенки и лимфоузлов интактных мышей с макрофагами (Галактионов В.Г., Мищенко Б.А., Самойленко А.С. и др., 1983).Обнаружен также высокий стимулирующий эффект хитозана на Jg М-и Jg G -антителопродуценты у мышей. Авторы считают, что точкой приложения действия хитозана., вероятно, являются Т-хелперы. Однако не исключают возможность влияния хитозана непосредственно на В-клетки.

Таким образом, можно сделать вывод, что хитозан является высокоэффективным стимулятором естественной резистентности организма животных.

\subsection{4. Механизм действия цеолитов}

В сельском хозяйстве применение природных цеолитов началось с 60-х годов двадцатого столетия. Многоцелевое использование цеолитсодержащих пород для решения медико-биологических и 
сельскохозяйственных проблем, технологических и природоохранных задач делают необходимым всестороннее изучение этого вида минерального сырья.

Природные цеолиты - мелкопористые каркасные алюмосиликаты кристалической структуры, содержащие каналы пустоты, занятые крупными ионами и молекулами воды. Благодаря особенностям кристаллического строения (наличие микропор, высокой подвижности молекул и обменных катионов), цеолиты имеют уникальные адсорбционные свойства, являясь хорошим адсорбентом для многих неорганических веществ, способным поглощать и выводить из организма токсические продукты пищеварения, токсические вещества, разные газы, в том числе углекислый газ, двуокись серы, окислы азота, аммиак, хлор, хлористый водород и другие. (Н. Ф. Челищев, 1974; Alietti A., Brigatti M.F., 1977).

В природе цеолиты имеют осадочное, вулканоосадочное или вулканическое происхождение, встречаются в виде клиноптилолита, филлипсита, гейландита, морденита, кремнеземистого мергеля и других. Месторождения природных цеолитов открыты в России, США, Японии, Италии, Канаде, Болгарии, Венгрии и др. На территории России, цеолитовые туфы обнаружены в Закавказье, Средней Азии, на Сахалине, Камчатке, Восточной и Западной Сибири, Среднем Поволжье, Якутии, Бурятии. Всего ресурсы цеолитовых туфов в России составляют около 10 млрд. тонн.

Многочисленными исследованиями установлено, что использование цеолитов в качестве минеральной добавки в кормлении сельскохозяйственных животных и птиц способствует улучшению усвояемости питательных веществ корма, увеличению живой массы и среднесуточных приростов, уменьшению расхода кормов на единицу продукции, предотвращает заболеваемость органов пищеварения. Эти минералы с успехом пользуются в кормлении сельскохозяйственных 
животных (Torii, 1978; Kondo, Wagai, 1964; Onagi T., 1965; Kondo, 1969; Сазонов Н.Н., Третьяков И.С., Колодезников К.Е., 1984; Колодезников К.Е., 1984; Колодезников К.Е., 2000).

Цеолиты, благодаря особенностям кристаллического строения (наличие микропор, высокой подвижности молекул и обменных катионов), обладают уникальными адсорбционными, ионообменными, молекулярно - и ионоситовыми свойствами. Они способны поглощать разные газы, в том числе углекислый газ, двуокись серы, окислы азота, аммиак, хлор, хлористый водород и другие, характеризуются термостабильностью, стойкостью к агрессивным средам и ионизирующим излучениям, достаточной механической прочностью, в них отсутствуют токсические соединения, исключено заражение минерала микроорганизмами (В.В. Байранов, С.И. Кирикилица, Т.В. Батиашвили, 1986).

Цеолиты - цеолитсодержащие ископаемые, осадочная горная порода, обладающая ионным обменом (цеолит -водосодержащее природное стекло). Области применения цеолитов определяются его физико-химическими свойствами: адсорбционными, ионообменными, каталитическими. При сочетании ионообменной и адсорбционной способности с наличием в нем жизненно важных для организма минеральных веществ: железа, меди, цинка, магния, калия, кальция и других делают его незаменимым диетическим продуктом при кормлении животных и птицы (В.И. Фисинин, Т.Н. Ленкова, И.А. Егоров, 1990).

Физиологические опыты свидетельствуют о положительном влиянии цеолитов на переваримость и усвоение питательных веществ рациона, на пищеварительные и обменные процессы в организме птицы. Они замедляют прохождение корма по желудочно-кишечному тракту, способствуют перетиранию частиц комбикорма, в результате чего питательные вещества корма становятся доступнее пищеварительным ферментам организма, их использование улучшается (У.Г. Дистанов, Т.П. Конюхова, 1990; В.И. 
Бгатов, К.Я. Мотовилов, М.А. Спешилова, 1987).

Возможно также действие цеолитов в качестве адсорбентов и катализаторов некоторых биохимических процессов. Путем ионного обмена и адсорбции цеолиты связывают метаболиты в кишечнике животных и птицы (в первую очередь аммиак и меркаптаны). Непосредственно возможным механизмом действия цеолитов на организм животных в первую очередь является их способность иммобилизации ферментов желудочнокишечного тракта. При вводе в рацион цеолитов значительно снижаются процессы брожения, происходящие в кормовой массе в период переваривания. За счет ионизации в полостях и каналах каркасах катионов натрия, калия, кальция, магния и других элементов цеолиты изменяют ионный состав химуса, нормализуя $\mathrm{pH}$ и, оптимизируя условия деятельности пищеварительных ферментов, при этом повышается активность ферментов липазы и пепсина.

Кроме того, они стимулируют гипертрофию и гиперемию митохондрий канальцев гладкой цитоплазматической сети, ответственный за синтез гликогена в печени. Вместе с цеолитами животные получают дополнительно ряд минеральных веществ (медь, железо, марганец, цинк, кобальт). Цеолиты способствуют усвоению этих же веществ, находящихся в кормах (А.В. Якимов, 1998, 2002; В.И. Фисинин, Т.Н. Ленкова, И.А. Егоров, 1990). Цеолиты способны выводить из организма животных соли тяжелых металлов (ртуть, свинец, кадмий), токсины, радиоактивные вещества, продукты метаболизма, снижать расстройства пищеварения, в результате чего создаются условия для нормального пищеварения и усвоения питательных веществ корма.

Введение цеолитов в комбикорма для животных способствует снижению влажности помета, уменьшению уровня аммиака в нем, в результате чего улучшается микроклимат помещений и как следствие их продуктивность (С.А. Водолажченко, А.Р. Мацерушко, 1987; Т.Р. Талызина, 
1997; Л.Е. Панин, Т.А. Третьякова, Д.С. Мирсаяфов, А.В. Харьковский и др., 1992). Поэтому, повышение продуктивности и эффективности использования питательных веществ кормов при использовании в качестве добавок к комбикормам цеолитов объясняется улучшением физиологического состояния организма сельскохозяйственных животных.

Из литературных данных известно, что цеолиты переносят биологически активные вещества из одного отдела пищеварительного тракта в другой. Цеолиты могут служить источником важных минеральных веществ, подвижные формы которых под действием резких перепадов рН (от 1 до 9), различных пищеварительных ферментов и солевых растворов извлекаются в полость пищеварительного канала, всасываются и положительно влияют на электролитный обмен (Колодезников К.Е., Степанов В.В, Матросова Т. В., 1991).

Добавка цеолита в корм молодняку сельскохозяйственных животныхв количестве 2-3\% от массы полнорационного комбикорма, способствовала увеличению содержания в крови лейкоцитов, доли альбуминов и гаммаглобулинов, уровня неорганического Р, резервной щелочи и каталазы (Панин Л.Е., Третьякова Г.А.. Розуменко А.А., Колосова И.Е., Останина Л.С., 1990; Каланчюк Г., 1990). Повышается перевариваемость питательных веществ, увеличивается отложение в теле Са, Р, при этом снижается содержание жира. Наблюдалось увеличение среднесуточного прироста на 8\%, выявлена экономия кормов на единицу прироста на $11 \%$.

Цеолитовое сырье месторождения Хонгуруу в Республике Саха (Якутия) названо хонгурином. Хонгурин - это природный минерал со структурой, напоминающей тонкопористую кристаллическую губку, в полостях которых размещены слабо связанные с основным алюмосиликатным каркасом катионы $\mathrm{Ca}, \mathrm{Mg}$. $\mathrm{Na}$ и $\mathrm{K}$, а также молекулы воды. Эти катионы свободно обмениваются с катионами внешней среды (вода, почва и т.д.) при комнатной температуре (Колодезников К.Е., 2000; 
Новгородов П.Г., 2000). Уникальные адсорбционные, молекулярные и ионообменные свойства хонгурина позволяют использовать его во многих отраслях народного хозяйства.

Исследования, проведенные на лабораторных животных по учету генетических и половых мутаций, показали отсутствие мутагенной активности хонгурина даже при действии в дозах, значительно превышающих реальные. Учитывая тесную корреляционную зависимость мутагенного эффекта с канцерогенезом, вряд ли можно ожидать и возникновения каких-либо онкологических последствий от воздействия данного цеолита на организм животных и человека.

Установлено, что хонгурин в дозах 1 г/кг и 0,4 г/кг не вызывает общего токсического действия на организм беременных крыс. Наоборот, введение хонгурина снижает общую эмбриональную смертность, способствует увеличению прироста массы тела беременных животных по сравнению с контролем. Отмечено положительное влияние препарата на уровень естественной резистентности. Так, установлено повышение бактерицидной активности сыворотки крови и фагоцитарной способности лейкоциотов. Таким образом, установлена целесообразность использования хонгурина в ветеринарной медицине в качестве носителя биологически активных веществ (Неустроев М.П., Тарабукина Н.П., 2000).

Сотрудники Якутского института геологических наук СО АН РФ провели опытные испытания хонгурина во многих отраслях промышленности, сельского хозяйства в сфере охраны окружающей среды и, как свидетельствуют результаты, является весьма эффективным и экологически выгодным сырьем. Внесение в почву хонгурина, пропитанного минеральными удобрениями, дает положительные результаты: урожайность зеленой массы овса увеличилась на 15,9 ц/га по сравнению с контролем.

Исследования по дистанционному влиянию хонгурина проведены на лабораторных крысах линии Вистар. В качестве наркотического вещества 
использовали диэтиловый эфир. В эксперименте использованы 2 группы крыс, пораженных бронхопневмонией. Опытная группа животных была помещена в клетку, обитую хонгурином. На 30-сутки эксперимента у крыс опытной группы признаки бронхопневмонии не отмечаются, тогда как в контрольной группе патологический процесс сохраняется (Абрамова П.С., Гармаева Д.К., Анцупова С.Г., 2000).

Использование хонгурина в качестве дезодоранта в животноводческих помещениях позволяет снизить концентрацию вредных газов (аммиака) на $36 \%$, уменьшить влажность воздуха на 5\% и таким образом, повысить температуру в помещении на 2, 3 градуса Цельсия.

Эффективность добавок хонгурина в кормлении сельскохозяйственных животных объясняется многими непосредственными и вторичными (опосредованными) механизмами воздействия цеолитов на организм, основанными на его уникальных физико-химических свойствах: ионообменные, адсорбционные, каталические и др. Это позволило нормализации минерального питания и улучшении физиологического состояния животных. (Иванов Р.В., 1993; Буковская 3.И., 1999; Иванов Р.В., Евсеев П.П., 2000; Сазонов Н.Н.,1993; Саввинова М.С., 2000; Черноградская Н.М.и др., 1993, 2000, 2006).

По мнению А.В.Горбунова и И.А.Белицкого (1990), в основе биологического действия цеолитов на живой организм лежат их физикохимические свойства, включающие сложный комплекс взаимодействий: ионный обмен, адсорбцию, катализ, минеральный обмен, которые зависят от структуры кристаллической решетки, типа обменных катионов, степени их сорбции и десорбции. Это взаимодействие цеолитов с живым организмом реализуется через химические, физические и механические процессы, сопровождающиеся изменениями как самой цеолитсодержащей породы, так и контактирующих с ней биологических объектов (В.Н.Николаев, 1990).

Многие ученые (М.М. Дубинин, 1977; В.П. Кавин, 1991; М.Я. Тремасов, 
1996) биологическую активность цеолитсодержащих пород объясняют их ионообменной способностью. В организме животных обмену подлежат многие ионы, что, несомненно, играет благотворное влияние на гомеостаз. Организм освобождается от токсичных веществ и снабжается микро- и макроэлементами.

Корма, входящие в состав рационов, которые применяются сегодня, практически обеспечены минеральными веществами. Вместе с тем некоторые природные минеральные вещества (цеолиты) могут быть успешно использованы в звероводстве (Балакирев Н.А., Кузнецов Г.А., 2006).

Учитывая особенности кормлении и физиологии пищеварении пушных зверей, можно предположить, что уникальные физико-химические свойства природных цеолитов могут способствовать повышению продуктивного деиствии кормовых рационов, роста молодника и качества пушнины. Однако литературные данные об использовании природных цеолитов в пушном звероводстве весьма немногочисленны.

В опытах Н.А. Балакирева и Е.А. Лариной (1990), скармливание цеолитов Шивыртуиского месторождения в дозах 0,$16 ; 0,33 ; 0,5 \%$ от сухого вещества корма не оказывало отрицательного влияния на физиологическое состояние норок. Однако при этом не регистрировали и положительного эффекта в увеличении массы тела зверей.

Позднее Н.А. Балакирев и В.С. Снытко (1995) установили, что оптимальная доза цеолитов для норок в период воспроизводства должна составлять 0,3\% от массы корма. При включении молодняку норок препарата в дозе $0,7 \%$ возрастает живая масса, а также количество нормальных и особо крупных шкурок.

Проведенные исследования О.Д. Захаровой, З.И. Буковской (1991), показали, что использование хонгурина повышает приросты живой массы, длину тела и обхват груди, снижает отход молодняка лисиц до регистрации, а также повышает качество шкурок (Иванов Р.В., 2002). 
В опыте И.И. Мещерякова (1990), скармливание 3\% цеолитового туфа (от массы сухого вещества корма) Шивыртуиского месторождения серебристым лисицам способствовало снижению заболеваемости на 50-75\% и смертности зверей; повышению плодовитости (на 0,5 головы) и молочности маток (по массе гнезда на $12-15 \%$ ); при этом исчезали случаи самопогрызания животных.

М.С.Ежкова и О.А.Якимов (1999) установили, что при добавлении лисам и песцам с 4,5-недельного возраста до убоя цеолитсодержащей кремнисто-карбонатной породы Татарско-Шатрашанского месторождения в количестве $1 \%$ от массы корма и йодистого калия в дозе $1 \%$ от сухого вещества корма, их средняя живая масса к концу опыта была на 16-24,3\% больше, чем в контроле. При этом увеличились размеры и улучшилось качество шкурок.

В опытах, проведенных О.А. Якимовым (2000) установлено, что скармливание цеолита взрослым норкам стимулировало восстановление массы тела, потерянной в подсосный период, а также сохранность щенков на $7,7 \%$ и интенсивность их роста - на 14,3-17,5\%. Под влиянием цеолита улучшалось функциональное состояние щитовидной железы, а также повышались фильтрационные и реабсорбционные процессы в почках. Оптимальной дозой цеолитов для норок в период воспроизводства является 0,3\% массы корма, что повышает выход на основную самку на 0,3 щенка. При включении в рацион молодняка норок цеолита в дозе 0,7\% массы корма возрастает количество бездефектных и особо крупных шкурок до 7\%, что повышает зачет по качеству на 3\% (Балакирев Н.А., Кузнецов Г.А., 2006).

Результаты производственной проверки цеолитсодержащего мергеля и глины Татарско-Шатршанского, бентонитовой глины Верхне-Нурлатского, цеолитового туфа Холинского и диатомитовой породы Инзенского месторождений показали, что у щенков норок и песцов, получавших дополнительно к основному рациону добавки природных минеральных 
сорбентов в количестве $0,5 \%$ и 1,0\% от массы корма, приросты живой массы и масса к убою были выше контрольных показателей на 6,5-10,2\% (P $\leq 0,05)$, а также улучшились количественные и качественные показатели шкурковой продукции (Гайнуллина М.К., 2006).

Имеются единичные данные об использовании цеолитов в рационах кроликов. По данным Н.А. Балакирева и В.С.Александровой (1997), добавки шивыртуина в количестве 1-3\% массы комбикорма молодняку кроликов в возрасте с 50 до 100 дней обеспечивали достоверное повышение на 8,1-9,4\% живой массы к концу откорма, а также сохранность животных при снижении затрат корма на 13-16\%. В опытах Г.А.Таланова и др. (1996), при совместном скармливании орловских цеолитов с тиосульфатом в соотношении 10:1 получены более высокие показатели прироста массы кроликов, чем при введении одних цеолитов.

Цеолиты, обладая адсорбционными и каталитическими свойствами, благодаря которым их используют в качестве минеральной, диетической и лечебно-профилактической добавки в рационах животных. Цеолиты эффективны при отправлениях различными токсическими веществами, в том числе солями металлов, пестицидами, нитратами и нитритами, ядохимикатами. Цеолиты нейтрализуют токсичные и химические вещества, что приводит к улучшению физиологического состояния организма, повышает сопротивляемость к заболеваниям, способствует лучшему использованию питательных веществ рациона (Балакирев Н.А., Кузнецов Г.А., 2006).

Таким образом, приведенные данные свидетельствуют о том, что природные цеолиты повышают продуктивность сельскохозяйственных животных. С учетом вышеизложенного изучение эффективности использования цеолита в рационах гипотрофичного молодняка клеточных пушных зверей является актуальным. 
ОБЩАЯ СХЕМА ИССЛЕДОВАНИЙ

Рис. 1

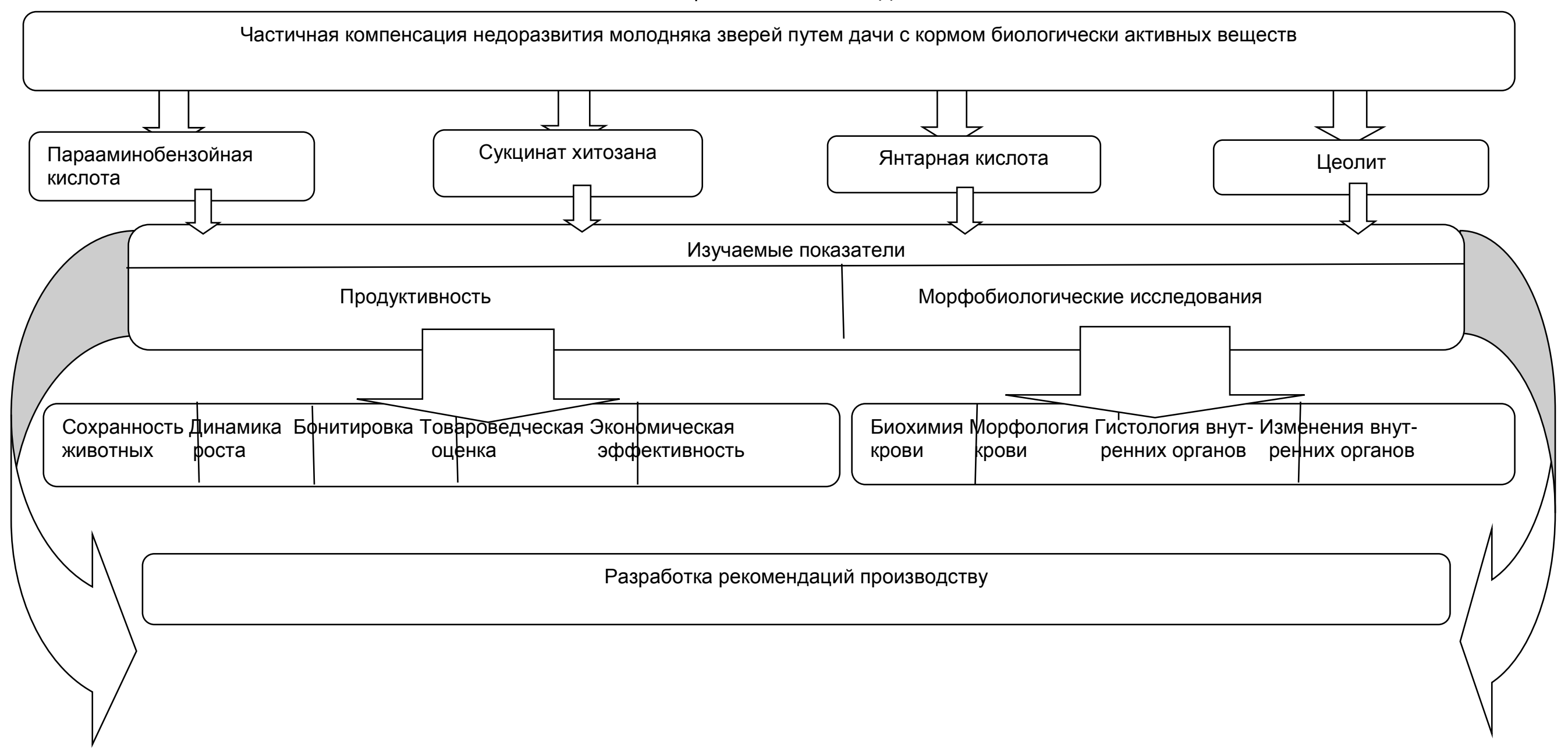




\section{Глава 2. Материал и методика исследований}

Работу проводили в период с 1992 по 2006 годы в условиях хозяйств различных форм собственности Республики Саха (Якутия) - в совхозе «Онерский» Усть-Алданского улуса, в Покровском цехе звероводства ГУП ФАПК «Сахабулт» Хангаласского улуса, на племенных зверофермах «Одуну» Горного улуса, «Сутороха» Абыйского улуса, «Чепара» Чурапчинского улуса, в Национальном центре медицины РС (Я), в институте экспериментальной ветеринарии при Якутском ГСХА.

Было проведено пять научно-хозяйственных опытов и производственная апробация на гипотрофичном молодняке серебристочерных лисиц. Объем и направление исследований представлены в схемах проведения научно-хозяйственных опытов в таблицах 1 и рис.1.

При проведении опытов животных подбирали в группы по принципу групп-аналогов с учетом породы, возраста, пола, живой массы.

Таблица 1

Схема опытов

\begin{tabular}{|l|l|}
\hline $\begin{array}{l}\text { Группы } \\
\text { подопытных } \\
\text { животных }\end{array}$ & \multicolumn{1}{c|}{ Условия кормления } \\
\hline \multicolumn{1}{|c|}{} & \\
\hline & Основной рацион (ОР) \\
\hline I конт. & ОР+парааминобензойная кислота 0,5мг/кг живой массы \\
\hline II опыт. & ОР+парааминобензойная кислота 1,0мг/кг живой массы \\
\hline III опыт. & ОР+парааминобензойная кислота 1,5мг/кг живой массы \\
\hline IV опыт. & \\
\hline & Основной рацион (ОР) \\
\hline I конт. & ОР+сукцинат хитозана 0,5 мг/кг живой массы \\
\hline II опыт. & ОР+сукцинат хитозана 1,0мг/кг живой массы \\
\hline III опыт. &
\end{tabular}


Продолжение таблицы 1

\begin{tabular}{|l|l|}
\hline \multicolumn{1}{|c|}{1} & \\
\hline IV опыт. & ОР+сукцинат хитозана 1,5 мг/кг живой массы \\
\hline I конт. & Основной рацион $($ ОР) \\
\hline II опыт. & ОР+янтарная кислота 10 мг/кг живой массы \\
\hline III опыт. & ОР+янтарная кислота 20 мг/кг живой массы \\
\hline IV опыт. & ОР+янтарная кислота 40 мг/кг живой массы \\
\hline I конт. & Основной рацион (ОР) \\
\hline II опыт. & ОР+цеолит 1,0г на голову \\
\hline III опыт. & ОР+цеолит 5,0г на голову \\
\hline IV опыт. & ОР+цеолит 10,0г на голову \\
\hline I конт. & Основной рацион (ОР) \\
\hline II опыт. & ОР+парааминобензойная кислота 1,0мг/кг живой массы \\
\hline III опыт. & ОР+сукцинат хитозана 1,0мг/кг живой массы \\
\hline IV опыт. & ОР+янтарная кислота 40мг/кг живой массы \\
\hline V опыт. & ОР+цеолит 5,0г на голову \\
\hline I конт. & Основной рацион (ОР) \\
\hline II опыт. & ОР+парааминобензойная кислота 1,0мг/кг живой массы \\
\hline III опыт. & ОР+сукцинат хитозана 1,0мг/кг живой массы \\
\hline IV опыт. & ОР+янтарная кислота 40мг/кг живой массы \\
\hline V опыт. & ОР+цеолит 5,0г на голову \\
\hline
\end{tabular}

Биологически активные вещества добавляли в кормосмесь, тщательно перемешивали и скармливали с 40-суточного возраста. Звери опытных групп получали парааминобензойную кислоту, сукцинат хитозана и янтарную кислоту в течение 9 суток с интервалом в 1 сутки, цеолит 1 раз в сутки - 30 дней.

Содержание и кормление зверей опытных и контрольной групп было одинаковым, щенки получали единый общехозяйственный рацион.

Дозировку биологически активных веществ определяли по методике Ю.К. Свечина, Н.Н. Борисовой (1988; 2001), М.С. Найденского (1996), Г.Н. Шангина-Березовского(1978), 3.И. Буковской (1991).

В опытах учитывали следующие показатели:

а) Живую массу щенят определяли в 30 -дневном и 40-дневном возрасте 
с точностью до 5 г., а в 4 - месячном возрасте - до 50г. Учитывали индивидуальную динамику роста массы самцов и самок. Одновременно у подопытных животных брали промеры тела: длину тела, обхват груди, с точностью до 0,5 см. На основании этих данных вычислялись индексы: весовой и сбитости. При изучении роста молодняка лисиц мы определяли: абсолютный прирост, среднесуточный прирост и относительный прирост по общепринятой методике,

б) Морфобиохимические показатели крови: у зверей опытных и контрольных групп в возрасте 2 и 4 месяцев брали кровь из плантарной вены и проводили морфологические и биохимические исследования (Кондрахин И.П., 1985).

в) Проводили бонитировку подопытного молодняка: В период полного формирования меха (октябрь) самок и самцов всех групп бонитировали в соответствии с требованиями ОСТ № 10 10-86. При этом оценивали размер и телосложение зверей, качество и окрас волосяного покрова, на основании чего присваивали соответствующий класс.

г) Проводили оценку структуры волосяного покрова подопытного молодняка: При этом пользовались методикой Б.А. Кузнецова (1952). В период полного созревания зимнего волосяного покрова брались пробы волос выщипом на границе последней трети тела зверя и на расстоянии 5 см от хребтовой линии. В каждой пробе измеряли естественную длину 25 пуховых и 25 остевых волос, ширину серебристого кольца и длину пигментированного участка в вершине серебристых и платиновых волос.

д) Убой зверей проводили электрическим током. Сразу после убоя из трупов зверей извлекали внутренние органы для взвешивания и измерения (сердце, легкие, печень, желудок, почки и кишечник). Сердце перед взвешиванием освобождали от сердечной сумки и крови, легкие - от трахеи. Желудок и кишечник освобождали от содержимого и промывали. Печень освобождали от диафрагмально-печеночных связок и желчного пузыря; 
е) Первичную обработку шкурок зверей проводили в условиях хозяйства. Сортировали шкурки согласно требованиям ГОСТ № 2790-88 (по цвету, размеру, сорту, \% серебристости и группам дефектов). Комиссионную оценку шкурок с учетом качества волосяного покрова проводили совместно со специалистами хозяйств.

ж) Проводили гистологические исследования печени, почек и селезенки в Национальном центре медицины Республики Саха (Якутия).

з) Полученные в опытах данные обрабатывали методом вариационной статистики. При этом определяли среднюю арифметическую величину и ее ошибку $(\mathrm{X} \pm \mathrm{m})$, среднее квадратическое отклонение $(\sigma)$, достоверность разницы между средними арифметическими (td), уровень вероятности (P) по методике Н.А. Плохинского (1969). Достоверной считали разницу между группами при $\mathrm{P}>0,95$. Для определения оптимальной дозы и величины влияния биологически активных веществ проводили двухфакторный дисперсионный анализ. Математическую обработку полученных результатов и вычислений проводили с использованием программного приложения Microsoft Excel из программного пакета Microsoft Offise 97.

и) После завершения научно-хозяйственных опытов была проведена производственная апробация результатов исследований.

к) Экономическую эффективность применения ПАБК, СХ, ЯК и цеолита на отстающих в росте щенятах лисиц рассчитывали согласно методическим рекомендациям НИИПЗК (1984).

\section{Глава 3. Состояние и перспективы развития клеточного звероводства}

\section{1. Современное состояние клеточного звероводства в РС (Я)}

Многолетняя практика якутских звероводов показала, что клеточное звероводство хорошо сочетается с животноводческими отраслями, которые традиционно развиваются в Якутии, что дает возможность выгодно 
использовать отходы животноводства и охотничьего промысла в корм пушным зверям (Никанорова М.И., Дьячковский М.И., Черкашина А.Г. и др., 2004).

К сожалению, в последние годы в связи с распадом крупных хозяйств ранее высокодоходная отрасль звероводство превратилась фактически в бесхозную, никому не нужную (Бойнов А.И., Буковская 3.И., 1995).

Анализ данных поголовья клеточных пушных зверей в динамике за период 1991...2005 г.г. показывает, что если в 1991 г. в республике насчитывалось 15575 голов серебристо-черных лисиц, то в 2005 году их осталось всего лишь 4813 голов, что почти в 3 раза меньше.

Если проанализировать ситуацию лисоводства в Якутии за последние годы, то можно сделать следующие выводы - поголовье серебристо-черных лисиц в 2005 году по Республике Саха (Якутия) составило 4813 голов, тогда как в 2004 году оно составило 5448 голов. Самое большое количество насчитывает Хангаласский улус - 3337 голов и Абыйский улус - 265 голов. Получено приплода в 2003 году 17794 голов, что на 42\% выше показателей 2002 года. Падеж серебристо-черных лисиц всех возрастов по республике составил 2656 голов, что в 2,9 раз больше по сравнению с 2002 годом.

В связи с резким снижением поголовья лисиц, уменьшилось и количество получаемых шкурок. Например, в 1998г. выращено и забито на шкурку только 17,7 тыс. голов, что составило 7,06\% от аналогичных показателей России.

Неустойчивая кормовая база и низкий уровень племенной работы привели к тому, что в настоящее время наблюдается низкая воспроизводительная способность клеточных пушных зверей в Республике Саха (Якутия), в частности - серебристо-черных лисиц. По итогам гона 2005 года деловой выход лисиц в республике составил 3,5 головы, тогда как в по зверохозяйствам России этот показатель равнялся 5,14 голов на 1 самку.

В зверохозяйствах Республики Саха (Якутия) период гона начинается с 
1 февраля до конца марта - середины апреля. Благодаря спариванию в указанные сроки щенение самок и выращивание молодняка приходятся на более благоприятное по температурным и кормовым условиям время весенне-летние месяцы.

Наличие охоты у самок лисиц определяют, как и в других регионах России, комбинированным методом - по изменению наружных половых органов (петли) и по поведению самок и самцов, ссаженных в клетку самца.

Соединение самцов с самками проводят в утренние часы, когда звери наиболее активны. Большая часть самок спаривается на второй день охоты. Гон заканчивается покрытием планового количества самок в конце марта.

В зверохозяйствах Республики Саха (Якутия) сравнительно большое количество самок (46,7\%) спаривается 2 раза двумя разными самцами, затем следует покрытие 2 раза одним самцом (32 \%). Наименьшее количество самок спаривалось один раз с одним самцом $(4,36 \%), 3$ раза - с одним самцом (6,96 \%) и 3 раза - с двумя самцами (9,98\%). Из этого следует, что всего покрытие одним самцом происходило у 43,32 \% самок. Двумя самцами спаривалось 56,68 \% самок, т.е. на 31 \% больше самок спаривались двумя разными самцами.

Таким образом, в РС (Я) преобладают двукратные покрытия, причем, двумя разными самцами. Однократное покрытие самок во всех хозяйствах очень низкое, хотя при этом методе гона меньше «изнашиваются» самцы, молодняк рождается известного происхождения, и этим создаются лучшие возможности для отбора в племенных целях.

Воспроизводительная способность самок зависит в большей степени от их подготовленности к гону. Своевременная отсадка щенят от самок способствовало тому, что самки основного стада в период лактации чрезмерно не истощаются, у них своевременно начинается подготовка организма к следующему размножению.

Анализ результатов гона и щенения самок серебристо-черных лисиц в 
Республике Саха (Якутия) показывает, что процент пустых самок с годами снижается. В 1999 году 37 процентов пустых самок составлял 6,3, в 2000 году сократился на 4,3, а в 2001 году - на 3,4 \%. Наибольший процент от количества всех самок без приплода имеют самки, у которых были неблагополучные роды или аборты. В 1999 году аборт и неблагополучные роды (нбр) составили 21,2 \%, что отрицательно повлияло на плодовитость зверей. Наибольший процент абортов и неблагополучных родов отмечен в 2000 году и равнялся 26,3, а в 2001 году он несколько снизился (на 9,9 \%). Эти показатели в основном зависят от условий кормления и содержания зверей в различные периоды их жизни.

Пустуют в основном молодые и старые самки. Надо большое внимание уделять кормлению первородок. От этого зависит развитие и созревание у них половых органов. Если их хорошо кормить, то они наравне с взрослыми самками будут приходить в охоту, уменьшается процент пустующих и холостых, и они как и взрослые самки будут иметь высокие показатели воспроизводительной способности.

Наибольший процент самок без приплода отмечен в 2000 году (28,3 \%) и в 1999 году (27,5 \%), а в 2001 году процент самок без приплода сократился на $9 \%$.

В 1999 году было получено 8986 щенков, а в 2001 году было получено на 39,49 \% больше щенков. Сохранность молодняка серебристо-черных лисиц в эти годы составила 70,78 - $81.37 \%$.

Продолжительность беременности лисиц в условиях РС (Я) колеблется в среднем от 53 до 54 дней (в норме 51-52 дня). Причинами нарушения продолжительности беременности чаще всего является дефицит в рационе самок витаминов группы В, особенно во вторую половину беременности. Чаще всего затягивается беременность у малоплодных самок. Самым главным в период беременности является рациональное кормление самок по всем питательным веществам и создание спокойной обстановки на ферме. 
Щенение начинается с третьей декады марта и заканчивается в середине мая. К щенению за 10..15 дней звероводы подготавливают домики для щенения. В зависимости от типа домика в него вставляют специальное гнездо и проводят утепление домика.

Роды у лисиц чаще всего проходят рано утром, длятся они обычно 1,5...2 часа. Как только щенок родился, самка вылизывает его, освобождает от плаценты, которую съедает, и подкладывает его к соску.

Ранняя проверка помета позволяет своевременно обнаружить слабых щенков, и оказать им помощь и предупредить их гибель (отогреть остывших в специальных ящиках с электрообогревом, подкормить и оказать различную ветеринарную помощь).

В силу короткого периода беременности детеныши рождаются слепыми, беззубыми, с плотно закрытыми слуховыми проходами. Они большеголовы, с удлиненным телом и относительно короткими конечностями и хвостом. Новорожденные щенки лисиц имеют живую массу 80..100г. В первые дни жизни у них наиболее интенсивно растут конечности, затем голова и туловище. К 5-6-месячному возрасту, щенки лисиц приобретают пропорции взрослых животных (Ильина Е.Д., Соболев А.Д., 1990).

Анализ сроков щенения самок серебристо-черных лисиц в РС (Я) показал, что большинство самок щенится с 14 апреля по 12 мая: в 1999 году 81,36 \%, в 2000 году - 78,9 \%, в 2001 году -78,3\%. Щенки, которые родились с 30 марта по 14 апреля, считаются щенками раннего срока рождения и они наиболее желательны в хозяйстве. Наименее желательны щенки поздних сроков рождения (это срок от 12 до 24 мая). Так, в 1999 году с 30 марта по 14 апреля щенились 9,69 \% самок, а в позднем сроке - 8,93 \% самок. В 2000 и 2001 годах количество ранних щенков по сравнению с 1999 годом повысилось (в 2000 г. на 4,61 \%, в 2001 г. на 3,37 \%) и, вместе с тем, сократились поздние сроки щенения (в 2000 г. на 2,13%, в 2001 г. на 0,23\%). 
Из года в год во всех зверофермах республики ведется отбор молодняка текущего года на племя. Из них на выбраковку идет в среднем $29 \%$.

Возрастная структура самок свидетельствует, что лисицы в хозяйствах размножаются до 8-летнего возраста. В хозяйствах преобладают в среднем 25-летние самки. Но к сожалению из-за низких племенных качеств основного маточного состава, количество старых зверей из года в год увеличивается и к 2004 г. достигло 18\%. Как известно, у старых самок ухудшается с годами качество волосяного покрова. Также старый возраст самок отрицательно сказывается на получаемый молодняк, который бывает слабым, небольших размеров, с плохим опушением. И до забоя они просто не успевают приобрести нужную кондицию.

Анализ влияния возраста самок лисиц на результаты гона и щенения в 1997 году показал, что наибольший процент пустых самок у первогодок, у них самое меньшее количество нормально щенившихся самок и низкий деловой выход молодняка. Наихудшие показатели воспроизводительной способности отмечаются у самок старше 5 летнего возраста. Лучшие результаты размножения имели самки 2-5-летнего возраста.

Анализ рационов кормления нами приведен за 3 года. Для примера приведен анализ рациона серебристо-черных лисиц в период гона в Покровском цехе звероводства ГУП ФАПК "Сахабулт" в январе 2001 г. В суточный рацион включены мясные корма, субпродукты мясные, субпродукты костные, рыба морская, рыбы речная. Кроме того, имеется

Таблица 2

Рацион самок серебристо-черных лисиц Покровского цеха звероводства ГУП ФАПК «СахабулТ» в период гона за 2001 год

\begin{tabular}{|c|c|c|c|}
\hline \multirow[t]{2}{*}{ Корма } & \multirow{2}{*}{$\begin{array}{c}\text { Масса } \\
\text { корма, г }\end{array}$} & \multicolumn{2}{|c|}{ На 1 порцию в сутки, г } \\
\hline & & $\begin{array}{c}\text { Обменная } \\
\text { энергия }\end{array}$ & Переваримых, г \\
\hline
\end{tabular}




\begin{tabular}{|l|c|c|c|c|c|c|}
\hline & & Ккал & кДж & Протеин & Жир & Углеводы \\
\hline Мясные & 3,37 & 4,01 & 16,80 & 0,6 & 0,12 & - \\
\hline $\begin{array}{l}\text { Субпродукты } \\
\text { костные }\end{array}$ & 8,72 & 12,29 & 51,49 & 1,1 & 0,76 & 0,02 \\
\hline Рыба морская & 45 & 38,7 & 162,15 & 5,6 & 1,44 & - \\
\hline Рыба речная & 10,3 & 9,27 & 38,84 & 1,6 & 0,3 & - \\
\hline Комбикорм & 19,3 & 47,8 & 200,28 & 1,7 & 0,27 & 9,2 \\
\hline Отруби & 5,9 & 6,07 & 25,43 & 0,3 & 0,08 & 0,9 \\
\hline Капуста & 15,5 & 3,25 & 13,61 & 0,2 & 0,01 & 0,5 \\
\hline Прочие & 0,72 & 1,7 & 7,12 & 0,2 & 0,01 & 0,15 \\
\hline Итого: & & 123,09 & 515,72 & 11,3 & 2,98 & 10,77 \\
\hline
\end{tabular}

комбикорм, отруби, капуста, морковь, молоко, творог и прочие дополнительные корма (таблица 2 ).

В 2001 г. обменная энергия в 1 порции составила 123,09 ккал., что превышает норму в 1,23 раза, переваримый протеин составил 11,3 г. (\% обеспеченность 107,6 \%), переваримые жиры в 1 порции составили 2,98 г. (обеспеченность на 99,33 \%), переваримые углеводы - 10,73г.(\% обеспеченности в 1,5 раза превышает норму).

Исходя из вышеиложенного можно сказать, что кормление было не рациональное, особенно если учитывать, что он предназначен для периода гона.

Суточный рацион лисиц в период гона в Покровском цехе

Таблица 3

Рацион самок серебристо-черных лисиц Покровского цеха звероводства

ГУП ФАПК "Сахабулт" в период гона 2002 г. 


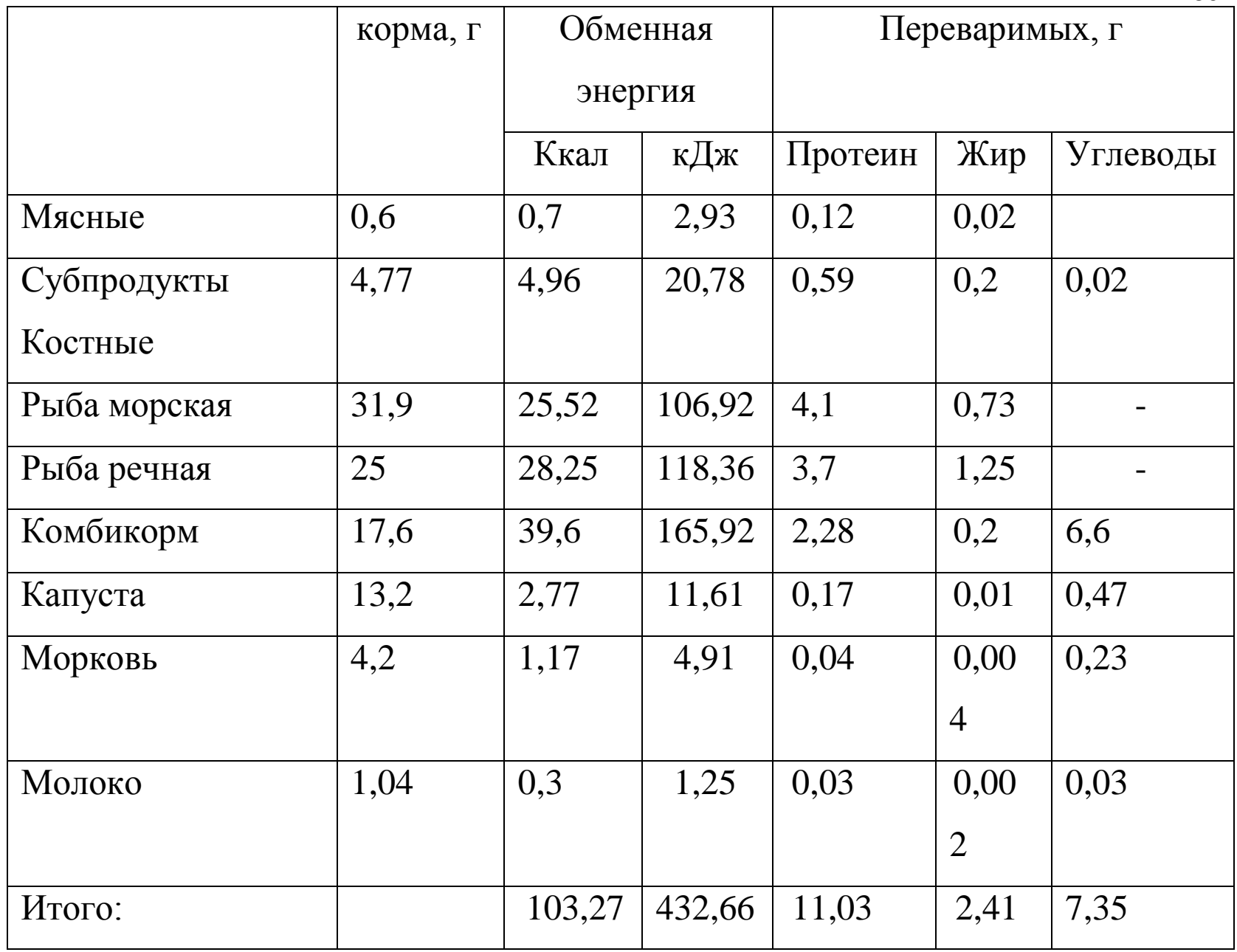

звероводства Государственном Унитарном Предприятии Финансово Агропромышленного Комплекса "Сахабулт" в январе 2002 г. включал в себя мясные корма, субпродукты мясные, субпродукты костные, рыбу морскую, рыбу речную, комбикорм, отруби, капусту, морковь, молоко, творог и прочие дополнительные корма.

В 2002 г. в 1 порции обменная энергия составила - 103, 27 ккал., что по обеспеченности - 103,27 \%, переваримый протеин составил - 11,03 г. (обеспеченность - 107,6\%), переваримые жиры составили 2,41 г. (обеспеченность 80,3 \%), переваримые углеводы 7,35 г. (обеспеченность 108,08\%) (таблица 3 ).

Исходя из вышеприведенных данных можно сказать, что рацион по сравнению с 2001 г. был более рациональным, соответствующим нормам кормления для лисиц в период гона. 
Таблица 4

Рацион самок серебристо-черных лисиц Покровского цеха звероводства ГУП ФАПК "Сахабулт" в период гона 2003 г.

\begin{tabular}{|c|c|c|c|c|c|c|}
\hline \multirow{3}{*}{ Корма } & \multirow{3}{*}{$\begin{array}{c}\text { Масса } \\
\text { корма, } \\
\text { г }\end{array}$} & \multicolumn{5}{|c|}{ На 1 порцию в сутки } \\
\hline & & \multicolumn{2}{|c|}{$\begin{array}{c}\text { Обменная } \\
\text { энергия }\end{array}$} & \multicolumn{3}{|c|}{ Переваримых, г } \\
\hline & & Ккал & кДж & Протеин & Жир & $\begin{array}{c}\text { Углево } \\
\text { ды }\end{array}$ \\
\hline Мясо сборное & 10 & 13,3 & 55,73 & 1,64 & 0,64 & \\
\hline Тушки & 6 & 11,16 & 46,76 & 0,99 & 0,70 & 0,036 \\
\hline Капуста & 8 & 1,76 & 7,37 & 0,10 & 0,008 & 0,28 \\
\hline Сайра & 6 & 18,7 & 78,35 & 1,03 & 0,76 & \\
\hline Рыба & 24 & 18,0 & 75,42 & 3,72 & 0,14 & \\
\hline Отход рыбный & 10 & 9,9 & 41,48 & 1,08 & 0,54 & \\
\hline Комбикорм & 11 & 28,6 & 119,83 & 0,95 & 0,31 & 5,20 \\
\hline Итого: & & 99,37 & 424,94 & 10,37 & 3,21 & 5,76 \\
\hline
\end{tabular}

В таблице № 4 представлен рацион за январь 2003 г. В рацион включены как корма живого, так и растительного происхождения.

В 2003 г. по обменной энергии за питательным веществом рацион соответствует рекомендуемым нормам.

Анализ кормления серебристо-черных лисиц Покровского Цеха Звероводства ГУП ФАПК "Сахабулт" в январе 2001...2003 г. показал, что в рационах отсутствовали добавочные корма, являющиеся основными источниками витаминов и минеральных веществ. Также в качестве нарушений следует отнести тот факт, что в анализируемые годы в рационах на долю рыбных кормов от всех кормов животного происхождения приходилось $62,55 \ldots 91,65 \%$. В 2002 г. в отличие от 2001 и 2003 гг. в 
рационах присутствует молоко, который, как известно, является наиболее высокоценным белковым кормом. В нем соотношение белка, жира и минеральных веществ значительно лучше, чем в любом другом корме. (Перельдик Н.Ш,, Милованов Л.В., Ерин А.Т., 1987).

Анализ воспроизводительной способности серебристо-черных лисиц в РС (Я) за 2001-2003 гг. показал, что поголовье самок основного стада за исследуемые годы составляло 3480...3528 голов (таблица 5).

Таблица 5

\section{Воспроизводительная способность серебристо-черных лисиц в} хозяйствах РС (Я)

\begin{tabular}{|c|c|c|c|c|c|c|}
\hline Годы & $\begin{array}{c}\text { Поголо- } \\
\text { вье на } \\
01.01 .\end{array}$ & $\begin{array}{c}\text { Покрыт } \\
\text { о самок, } \\
\text { голов }\end{array}$ & $\begin{array}{c}\text { Щени- } \\
\text { лось } \\
\text { самок, } \\
\text { голов }\end{array}$ & $\begin{array}{c}\text { Кол-во } \\
\text { Щенков, } \\
\text { голов }\end{array}$ & $\begin{array}{l}\text { Зарег-но } \\
\text { щенков, } \\
\text { голов }\end{array}$ & $\begin{array}{c}\text { Деловой } \\
\text { выход } \\
\text { на } 1 \text { шт. } \\
\text { самку, } \\
\text { голов }\end{array}$ \\
\hline 2001 & 3528 & 2778 & 2460 & 10628 & 10313 & 2,92 \\
\hline 2002 & 3519 & 3291 & 3265 & 14716 & 14361 & 4,08 \\
\hline 2003 & 3480 & 2364 & 1006 & 5485 & 4389 & 1,26 \\
\hline
\end{tabular}

Анализ результатов воспроизводительной способности серебристочерных лисиц в хозяйствах РС (Я) показал, что в 2001 г. поголовье серебристо-черных лисиц составило 3528 голов, из которых 2778 голов были покрыты, что составляло 78,7 \%. Из покрытых самок щенилось 2460 голов самок $(88,5 \%)$, количество щенков составило 10628 голов, т.е. плодовитость одной самки в среднем - 4,3 щенка. Зарегистрировано щенков 10313 голов. Деловой выход на 1 штатную самку составил 2,92 головы.

В 2002 г. поголовье лисиц составило 3519 голов, т.е. на 9 голов меньше, чем в 2001 году. Из них покрыты 3291 голов самок (93,5\%). Ощенилось 3265 голов самок, т.е. 99,2 \%. Количество щенков составило 
14716 голов, плодовитость одной самки составила 4,5 щенка. Зарегистрировано 14361 голов щенков. Деловой выход на одну штатную самку составил в 2002 г. 4,08 головы.

В 2003 г. поголовье лисиц составило 3480 гол., т.е. на 39 голов меньше, чем в 2002 г. Из них покрыто 67,93 \% голов, щенилось 1006 голов (42,55 \%). Количество щенков составило 5485 голов, т.е. в 2,6 раза меньше чем в 2002 г. К регистрации остались 4389 щенка. Деловой выход составил 1,26 гол. на 1 штатную самку, т.е. итоговый показатель воспроизводительной способности уменьшился в 3,23 раза. Пустуют в основном первогодки и старые самки. Необходимо сократить численность старых самок до $5 \ldots 10 \%$.

Для наглядного примера состояния клеточного звероводства в конце 90-х годов ХХ века приведен анализ звероводческой фермы коллективного предприятия "Оргет" Верхнее-Вилюйского улуса Республики Саха (Якутия) за 1995-1996 годы (таблица 6). В хозяйстве применяется полигамный метод разведения пушных зверей (полигамия составляет 1:3). Продуктивное стадо самок серебристо-черных лисиц в хозяйстве составляет 30 голов. Лисицы моноэстричные животные, поэтому проведение гона в звероводстве исключительно ответственная работа в организации производственного процесса. При недостаточной подготовленности организма зверей к воспроизводству или нарушении техники проведения гона некоторые самки зверей остаются не покрытыми (холостыми) или не оплодотворенными (пустыми).

По данным таблицы 6, за последние 2 года процент пропустовавших и неблагополучно ощенившихся самок в хозяйстве составил 27...33, тогда как удельный вес прохолостевших и пропустовавших самок в хозяйствах республики составил 20...30\%. 
Воспроизводительная способность лисиц в КП «Оргет» за 1995-

1996г.г.

\begin{tabular}{|c|c|c|c|c|}
\hline \multirow{2}{*}{ Показатели } & \multicolumn{2}{|c|}{1995} & \multicolumn{2}{|c|}{1996} \\
\cline { 2 - 5 } & Гол. & $\%$ & Гол. & $\%$ \\
\hline Количество самок,гол & 30 & 100 & 30 & 100 \\
\hline В т.ч. благ-но ощен-ся, гол & 22 & 73 & 20 & 67 \\
\hline Пустые, гол & 5 & 17 & 6 & 20 \\
\hline Неблагополучные роды, гол & 3 & 10 & 4 & 13 \\
\hline Всего без приплода, гол & 8 & 27 & 10 & 33 \\
\hline Число регист. щенков, гол & 92 & 100 & 120 & 100 \\
\hline $\begin{array}{c}\text { Пало щенков после } \\
\text { регистрации, гол }\end{array}$ & 15 & 16 & 26 & 21,6 \\
\hline Отсажено щенков, гол & 77 & 84 & 94 & 78,4 \\
\hline Деловой выход на 1 шт. & 2,6 & & 3,1 & \\
самку, гол & & & & \\
\hline
\end{tabular}

Пропустование самок является наиболее серьезным и распространенным пороком размножения. Одной из главных причин пропустования самок лисиц является несвоевременное покрытие. Период гона в хозяйстве начинаемся с 20-х чисел января, и продолжается до начала марта.

Пропустование самок в 1996 году повысилось по сравнению с 1995 годом на $6 \%$. Это можно объяснить снижением обеспеченности зверей высоко питательными и доброкачественными кормами в период подготовки к гону.

Для снижения пропустования самок необходимо: обеспечить хорошие условия кормления и содержания зверей в периоды подготовки к гону, гона и беременности.

Ухудшение кормовой базы также повлияло на снижение 
жизнеспособности щенков - по сравнению с 1995 годом в 1996 году отход щенят после регистрации повысился с 16 \% до 21,6\%. Уже доказано, что кормление зверей в периоды воспроизводства зверей влияет в первую очередь на жизнеспособности щенят. Этот показатель отражается на количестве отсаженных щенков. По результатам анализа воспроизводительной способности лисиц за 1995 и 1996 гг. в этом хозяйстве можно сделать заключение, что в целом по всем показателям воспроизводительности наблюдалось ухудшение, хотя в 1996 году деловой выход молодняка - 3,1 щенка. Массовые покрытия самок разными самцами увеличивает процент пропустования и отход молодняка, щенки рождаются неизвестного происхождения. В последствии они отбираются на племя и этим можно считать, что на плохие показатели воспроизводства самок, возможно, повлиял инбридинг. Также на воспроизводительные способности лисиц оказывает влияние возрастной состав стада. Как было сказано выше, в хозяйстве уделяется недостаточное количество внимания комплектованию стада. Поэтому в перспективе необходимо обращать внимание на возрастную структуру стада. Специалистам хозяйства необходимо внедрять в звероводстве систему зоотехнических приемов и организации племенной работы, борьбы против прохолостения и пропустования самок, падежа молодняка, рациональное кормление и содержание зверей. Умелое использование этих приемов в сочетании с организационными мерами представляет собой необходимое условие повышения продуктивности зверей и производства высококачественной пушнины.

Интенсивно клеточное пушное звероводство начало развиваться в Якутии с конца 30 годов прошлого века. При поддержке Правительства СССР зверофермы в колхозах и совхозах начали быстро набирать темпы роста и уже в 1981 году экспорт пушнины из республики был очень высок. С распадом СССР и утратой всех налаженных годами связей с поставщиками племенных зверей, кормов и т.д., клеточное звероводство Якутии начало 
медленно сокращать объем поставок клеточной пушнины государству. Только в 1994 году основное поголовье лисиц уменьшилось на 13,3\%, а песцов на 23,6\%, возрос падеж молодняка. Ухудшилось кормление зверей, которое отрицательно отразилось и на качестве шкурковой продукции: мелкие шкурки, больше дефектов волосяного покрова и т.д.

В 1995 году Республика Саха (Якутия), зная всю значимость клеточного звероводства как отрасли животноводства, приняла Постановление «Об особых мерах государственной поддержки ведения традиционных отраслей, жизнеобеспеченности и социальной защиты сельского населения арктических улусов». Постановлением Правительства от 27 февраля 1995 года №72 «О мерах государственной поддержки племенного дела в животноводстве» Суторохинская звероферма Абыйского улуса, Магарасская звероферма Горного улуса, звероферма Чепара Чурапчинского улуса и звероферма Люксугун Кобяйского улуса (по разведению голубых песцов) были преобразованы в племенные зверофермы. Одним из основных задач, решаемых племенными зверохозяйствами Якутии, является разведение адаптированных к местным климатическим и кормовым условиям пород клеточных зверей для получения высококлассной шкурковой продукции, отвечающей международным требованиям.

Основным критерием хорошо поставленной племенной работы в клеточном звероводстве являются, высокая воспроизводительная способность зверей и лучшие пушно-меховые качества получаемых от них шкурок. К сожалению, в настоящее время в нашей республике эти два вышеназванные показатели остаются низкими. Завоз зверей проводился с первых лет развития клеточного звероводства, поэтому если проследить этот не короткий период разведения лисиц и песцов в нашей республике можно сказать, что в хозяйствах уже должны были быть звери, адаптированные в климатических условиях. Но, к сожалению, особенно, в последние годы зоотехнический учет ведется не должным образом. И в этом случае, даже 
при наилучшей племенной работе, ни о каких высоких показателях клеточного звероводства говорить не стоит.

Ценность клеточных пушных зверей, разводимых в условиях Республики Саха (Якутия) заключается в следующем - это их отличная адаптация к низким уровням температуры, лучшее потребление и усвоение малопитательных веществ местного корма.

Проблемы с кормовой базой остаются острыми и в настоящее время. Нами изыскиваются пути стабилизации кормовой базы Якутии. Одним из путей решения этой проблемы мы считаем совершенствование технологии выращивания молодняка клеточных пушных зверей в условиях Республики Саха (Якутия). В ней огромная роль принадлежит совершенствованию технологии кормления, в том числе использование нетрадиционных кормов, кормовых добавок и биологически активных веществ.

3.2 Коррекция роста и развития гипотрофичного молодняка лисиц с помощью экологически безопасных препаратов - парааминобензойной кислоты, сукцината хитозана и янтарной кислоты.

3.2.1. Влияние парааминобензойной кислоты на рост и развитие гипотрофичного молодняка лисиц

Изменение живой массы молодняка является важнейшим показателем его роста и развития. При идентичных условиях содержания щенки поразному реагируют на изменение в составе рационов и условия кормления, вследствие этого дают неодинаковый прирост живой массы. С этой точки зрения изучение динамики живой массы подопытных щенков лисиц представляет определенный научный интерес.

Работами отечественных и зарубежных исследователей установлено, что стимуляторы обладают способностью усиливать обмен и повышать усвоение питательных веществ корма в организме зверей, в результате чего 
у последних увеличивается скорость роста (С.Л. Балаш, 1984; Г.И. Блохин, 1985; И.Н. Гамулинская,1985; Е.Г. Квартникова, 1989; О.Л. Рапопорт, 1987; Ю.К. Свечин, 1988, 1990; Baradasz В., 1985; N. Pelsdyrbl, 1986). Скорость роста при прочих равных условиях прямо зависит от массы тела. Масса организма определяет далеко не все, но влияние ее на происходящие в организме процессы велико.

Данные о результатах опыта, приведенные в таблице 7 свидетельствуют о том, что ПАБК положительно повлиял на рост и развитие живой масы, длины тела и обхвата груди подопытных щенят-гипотрофиков. К концу опыта средняя живая масса самочек опытных групп превосходила таковую в контроле на 0,29-0,54 кг или на 8,86-16,51 \%, а самцов - на 0,26-0,49 кг или на 7,69-14,49\% (достоверность у самок - Р > 0,999; у самцов П и Ш групп Р.>0,999; 1 У группы - Р >0,95 ).

Анализ сравнительных данных линейных промеров показал, что они находились в прямо пропорциональной зависимости от живой массы щенков. Наибольшими экстерьерными показателями отличался молодняк, имеющий большую живую массу.

По длине тела и обхвату груди в 4-месячном возрасте щенята опытных групп превосходили щенят контрольной группы. Самки опытных групп были длиннее на 8,55-11,61 \%, самцы - на 2,99-12,01\%. Разница достоверна по длине тела у самок и самцов Ш и 1 У групп $(\mathrm{P}>0,99)$, самцов П группы - $\mathrm{P}>0,99$.

Из таблицы 6 также видно, что по обхвату груди к концу опыта щенята опытных групп превосходили щенят контрольной группы. В опытных группах объем груди самок был больше на 3,58-8,99 \%,самцов - на 1,384,43\%. Достоверность разницы по обхвату груди у самок была равной П группы - P>0,95, Ш группы - P>0,999, у самцов Ш группы P>0,999.

Путем расчетов установлено, что среднесуточные приросты массы самок и самцов опытных групп (таблица 8) были выше, чем в контрольной 
Абсолютный среднесуточный и относительный прирост живой массы лисиц в контрольной и опытных группах

\begin{tabular}{|c|c|c|c|c|c|}
\hline \multirow[t]{2}{*}{ Показатель } & \multirow[b]{2}{*}{ Пол } & \multicolumn{4}{|c|}{ Группы } \\
\hline & & 1 & $\Pi$ & Ш & $1 \mathrm{y}$ \\
\hline Абсолютный среднесуточный & q & 28,3 & 34,0 & 34,2 & 31,2 \\
\hline прирост, г & $\sigma^{\pi}$ & 29,3 & 34,0 & 34,7 & 32,4 \\
\hline Относительный прирост & q & 354 & 425 & 421 & 374 \\
\hline живой массы, \% & $\sigma^{\lambda}$ & 356 & 408 & 422 & 405 \\
\hline
\end{tabular}

группе. О повышенной энергии роста щенят в этой группе свидетельствуют также показатели относительного прироста их живой массы. Из таблицы 8 видно, что относительный прирост живой массы у опытных щенят больше, чем у щенят в контрольной группе. Среднесуточный прирост живой массы самок в опытных группах больше на 2,9-5,9г или 10,24-20,84\%, чем в контрольной группе, самцов - на 3,1-5,4 г и 10,58-18,43\%. Относительный прирост живой массы за весь период опыта у самок опытных групп был больше на 20-71\%; самцов на 49-66\%.

Наиболее точно развитие щенят лисиц в процессе выращивания характеризуют индексы телосложения: весовой и сбитости, которые были вычислены на основании промеров статей экстерьера (таблица 9).

Показатели всех изучаемых признаков у щенят возрастали ежемесячно в соответствии с ростом живой массы.

Весовой индекс у самок опытных групп в 4-месячном возрасте был выше по сравнению с контрольной группой на 0,02-0,62\%, у самцов на 0,150,64\% (результаты достоверны у самок: $\mathrm{P}>0,999$, у самцов - $\mathrm{P}>0,95$ ).

Анализируя, представленные в таблице 9 показатели индексов 
телосложения у подопытных щенков лисиц, следует отметить, что стимулирующее влияние ПАБК больше отразилось на весовом индексе щенят опытных групп.

Из данных таблиц 7, 8, 9 видно, что самцы опытных групп превосходили самок по живой массе, что обусловлено их половым различием.

В период опыта было установлено влияние ПАБК на сохранность молодняка (таблица 10). В звероводстве отход молодняка определяют за 2 периода: первый - отход до регистрации и второй - отход после регистрации. Регистрация молодняка проводится на день отсадки щенков от матерей. В обоих случаях за 100\% берут общее количество родившегося молодняка. В исследуемых пометах мертворожденных щенят не было. В опыте выявляли отход до регистрации, а также учитывали количество сохранившегося молодняка к 4-месячному возрасту.

Таблица 10

Влияние ПАБК на сохранность подопытных щенят лисиц

\begin{tabular}{|c|c|c|c|c|c|c|c|}
\hline \multirow{2}{*}{ Группы } & \multirow{2}{*}{$\mathrm{n}$} & \multicolumn{2}{|c|}{$\begin{array}{l}\text { Отход щенят на } \\
\text { день регистрации }\end{array}$} & \multicolumn{2}{|c|}{$\begin{array}{l}\text { Отход щенят после } \\
\text { регистрации }\end{array}$} & \multirow{2}{*}{$\begin{array}{c}\text { Кол-во } \\
\text { щенят, } \\
\text { голов }\end{array}$} & \multirow{2}{*}{$\begin{array}{c}\text { Сохран- } \\
\text { ность, } \\
\%\end{array}$} \\
\hline & & $\mathrm{n}$ & $\%$ & $\mathrm{n}$ & $\%$ & & \\
\hline 1 & 20 & 7 & 35,0 & 4 & 20,0 & 9 & 45,0 \\
\hline$\Pi$ & 20 & 6 & 30,0 & 3 & 15,0 & 11 & 55,0 \\
\hline Ш & 20 & 5 & 25,0 & 1 & 5,0 & 14 & 70,0 \\
\hline $1 \mathrm{Y}$ & 20 & 7 & 35,0 & 2 & 10,0 & 11 & 55,0 \\
\hline
\end{tabular}

Материалы по отходу и сохранности щенят в группах представлены в таблице 10. Из данных этой таблицы видно, что сохранность щенят в опытных группах была выше, чем в контрольной группе. Так, отход щенков 
до регистрации во П и Ш опытных группах был на 5-10\% меньше, чем в контрольной группе. К концу опыта количество павших щенков в контрольной группе было больше, чем в опытной на 5-15\%. Это отразилось на сохранности молодняка лисиц. К 4-месячному возрасту в опытных группах сохранилось на 10-25\% больше, чем в контрольной, где щенки не получали ПАБК.

В целом подопытные щенки отличались хорошим состоянием здоровья, и не имели каких-либо патологических изменений. Повышение жизнеспособности и увеличение скорости роста щенков-гипотрофиков опытных групп согласуются с укреплением их физиологического статуса, о чем свидетельствует и достоверное увеличение показателей красной крови. Меньший отход и более высокая сохранность щенят в опытных группах по сравнению с контрольной группой обусловлены, очевидно, положительным влиянием ПАБК на организм этих животных.

Полученные в нашем опыте данные убедительно показывают, что применение ПАБК дает возможность в процессе выращивания значительно улучшить показатели роста и развития щенков, родившихся слабыми и с малой живой массой. При этом повышается и резистентность животных, о чем свидетельствует повышение их сохранности. Анализ полученных в этом эксперименте данных подтверждает закономерности, установленные Н.П. Чирвинским и А.А. Малигоновым о стадийности развития организма и о частичных компенсаторных его возможностях. Именно этим и можно объяснить тот факт, что щенки-гипотрофики, получавшие ПАБК имели более высокий относительный прирост массы тела на протяжении всего периода наблюдений.

Изучение интерьера сельскохозяйственных животных и состава компонентов их крови представляет возможность оценить не только напряженность обмена веществ, но и характеризовать устойчивость организма влиянию факторов внешней среды. 
Биологическое значение крови в организме животного исключительно велико. Посредством крови осуществляется важнейшее свойство живой материи - обмен веществ, гормональная регуляция и терморегуляция, поддерживается равновесие электролитов в организме и осуществляется защитная функция (Е.В. Эйдригевич, 1978). Исследованиями ряда авторов (Е.В. Эйдригевич, 1978，1969; Ю.А. Самков, 1979; Г.А. Комарова, 1985; Н.А.Деркач, 1971; Н.Я. Гунева, 1985; В.А. Берестов, 1981, 1966 ,2005; А.Д. Антипов,1987) установлена связь морфологического и биохимического состава крови с породой, конституцией, интенсивностью роста, живой массой, продуктивными и племенными качествами.

Особое внимание исследователи уделяли и уделяют изучению красной крови, представляющей большой интерес при метаболических процессах, которые обуславливают энергию роста и резистентность живого организма. 
Таблица 7

Динамика живой массы, длины тела и обхвата груди подопытного молодняка лисиц

\begin{tabular}{|c|c|c|c|c|c|c|}
\hline \multirow[t]{2}{*}{ Показатели } & \multirow{2}{*}{$\begin{array}{c}\text { Возраст } \\
\text { мес. }\end{array}$} & \multirow[b]{2}{*}{ Пол } & \multicolumn{4}{|c|}{ Группы } \\
\hline & & & $\begin{array}{c}1 \\
\text { к. }\end{array}$ & $\begin{array}{l}\Pi \\
\text { о. }\end{array}$ & $\begin{array}{l}\text { Ш } \\
\text { о. }\end{array}$ & $\begin{array}{c}\text { IV } \\
\text { o. }\end{array}$ \\
\hline \multirow[t]{4}{*}{ Живая масса, кг } & \multirow[t]{2}{*}{1} & q & $0,72 \pm 0,02$ & $0,72 \pm 0,01$ & $0,73 \pm 0,02$ & $0,75 \pm 0,01$ \\
\hline & & $0^{\lambda}$ & $0,74 \pm 0,01$ & $0,75 \pm 0,01$ & $0,74 \pm 0,02$ & $0,72 \pm 0,02$ \\
\hline & \multirow[t]{2}{*}{4} & o & $3,27 \pm 0,06$ & $3,78 \pm 0,05^{\mathrm{xxx}}$ & $3,81 \pm 0,04^{\mathrm{xxx}}$ & $3,56 \pm 0,07 \mathrm{xxx}$ \\
\hline & & o & $3,38 \pm 0,09$ & $3,81 \pm 0,04 \times x x$ & $3,87 \pm 0,06^{\mathrm{xxx}}$ & $3,64 \pm 0,06^{\mathrm{x}}$ \\
\hline \multirow[t]{4}{*}{ Длина тела, см } & \multirow[t]{2}{*}{1} & q & $28,30 \pm 0,24$ & $28,11 \pm 0,44$ & $28,35 \pm 0,35$ & $27,61 \pm 0,16$ \\
\hline & & $\widehat{0}$ & $28,92 \pm 0,20$ & $28,57 \pm 0,46$ & $27,91 \pm 0,49$ & $27,76 \pm 0,41$ \\
\hline & \multirow[t]{2}{*}{4} & q & $47,95 \pm 0,39$ & $50,84 \pm 0,40 \mathrm{xxx}$ & $53,52 \pm 0,57^{\mathrm{xxx}}$ & $52,05 \pm 0,50 \mathrm{xxx}$ \\
\hline & & 0 & $50,03 \pm 0,41$ & $51,53 \pm 0,35$ xx & $56,04 \pm 0,23 \mathrm{xxx}$ & $54,33 \pm 0,53^{\mathrm{xxx}}$ \\
\hline \multirow[t]{4}{*}{ Обхват груди, см } & \multirow[t]{2}{*}{1} & q & $18,20 \pm 0,23$ & $17,29 \pm 0,64$ & $17,46 \pm 0,81$ & $17,01 \pm 0,71$ \\
\hline & & o & $18,13 \pm 0,19$ & $18,25 \pm 0,50$ & $17,52 \pm 0,59$ & $18,31 \pm 0,55$ \\
\hline & \multirow[t]{2}{*}{4} & q & $32,89 \pm 0,43$ & $34,57 \pm 0,40^{\mathrm{xx}}$ & $35,85 \pm 0,39 \mathrm{xxx}$ & $34,07 \pm 0,56$ \\
\hline & & 0 & $34,96 \pm 0,25$ & $35,84 \pm 0,47$ & $36,51 \pm 0,33 \times x x$ & $34,98 \pm 0,41$ \\
\hline
\end{tabular}

${ }^{\mathrm{x}}-\mathrm{P}>0,95 ;{ }^{\mathrm{xx}}-\mathrm{P}>0,99 ;{ }^{\mathrm{xxx}}-\mathrm{P}>0,999$ 
Индексы телосложения лисиц разных групп

\begin{tabular}{|c|c|c|c|c|c|c|}
\hline \multirow[t]{2}{*}{ Показатели } & \multirow{2}{*}{$\begin{array}{l}\text { Возр } \\
\text { аст, } \\
\text { мес }\end{array}$} & \multirow[b]{2}{*}{ Пол } & \multicolumn{4}{|c|}{ Группы } \\
\hline & & & $\begin{array}{l}1 \\
\text { к. }\end{array}$ & $\begin{array}{l}\Pi \\
\text { o. }\end{array}$ & $\begin{array}{l}\text { Ш } \\
\text { o. }\end{array}$ & $\begin{array}{l}1 \mathrm{Y} \\
0 .\end{array}$ \\
\hline \multirow[t]{4}{*}{ Весовой индекс, \% } & 1 & P & $2,53 \pm 0,03$ & $2,56 \pm 0,07$ & $2,57 \pm 0,05$ & $2,71 \pm 0,03$ \\
\hline & & $0^{\pi}$ & $2,55 \pm 0,04$ & $2,62 \pm 0,07$ & $2,65 \pm 0,08$ & $2,59 \pm 0,03$ \\
\hline & 4 & q & $6,81 \pm 0,06$ & $7,43 \pm 0,07 \mathrm{xxx}$ & $7,11 \pm 0,03^{\mathrm{xxx}}$ & $6,83 \pm 0,08$ \\
\hline & & o & $6,75 \pm 0,10$ & $7,39 \pm 0,10 \times x \times$ & $6,90 \pm 0,15$ & $6,69 \pm 0,03$ \\
\hline \multirow[t]{4}{*}{ Индекс сбитости, \% } & 1 & 우 & $64,31 \pm 0,52$ & $61,51 \pm 1,41$ & $61,58 \pm 1,02$ & $61,60 \pm 0,80$ \\
\hline & & $\hat{0}$ & $62,69 \pm 0,52$ & $63,87 \pm 1,94$ & $62,77 \pm 0,98$ & $65,95 \pm 0,93$ \\
\hline & 4 & 우 & $68,59 \pm 0,68$ & $67,99 \pm 0,60$ & $66,98 \pm 0,45$ & $65,45 \pm 0,75$ \\
\hline & & $0^{\pi}$ & $69,87 \pm 0,83$ & $69,55 \pm 0,71$ & $65,14 \pm 0,67$ & $64,38 \pm 0,52$ \\
\hline
\end{tabular}

${ }^{\mathrm{x}}-\mathrm{P}>0,95 ;{ }^{\mathrm{xx}}-\mathrm{P}>0,99 ;{ }^{\mathrm{xxx}}-\mathrm{P}>0,999$ 
По мнению некоторых авторов (Х.Ф. Кушнер, 1974; А.Н. Титов, 1971 и др.) молодняк сельскохозяйственных животных, которому присущ интенсивный рост, отличается и повышенными показателями красной крови, в частности содержанием эритроцитов.

С целью выявления возрастной особенности морфологического и биохимического состава крови подопытных щенят лисиц, нами были взяты проба крови у щенят в возрасте 2-х и 4-х месяцев. Материалы этих исследований приведены в таблицах 11 и 12.

Из таблиц 11 и 12 видно, что полученные нами данные согласуются с работами ряда авторов (Н.А.Балакирев, 1989; В.А.Берестов, 1966, 1981) и что в течение опыта гематологические показатели у подопытных щенят лисиц в этом возрасте отклонений от физиологической нормы не имели.

Таблица 11

Гематологические показатели крови щенят лисиц

\begin{tabular}{|c|c|c|c|c|c|}
\hline \multirow[t]{3}{*}{ Показатели } & \multirow{3}{*}{$\begin{array}{l}\text { Воз- } \\
\text { раст } \\
\text { мес }\end{array}$} & \multicolumn{4}{|c|}{ Группы } \\
\hline & & $\mathrm{I}$ & II & Ш & $1 \mathrm{~V}$ \\
\hline & & к. & o. & o. & o. \\
\hline Эритроциты, & 2 & $7,01 \pm 0,38$ & $7,42 \pm 0,40$ & $7,25 \pm 0,27$ & $7,24 \pm 0,31$ \\
\hline мЛн./Mм ${ }^{3}$ & 4 & $8,84 \pm 0,20$ & $9,09 \pm 0,56$ & $9,33 \pm 0,29$ & $9,21 \pm 0,35$ \\
\hline Лейкоциты, & 2 & $6,84 \pm 0,52$ & $6,94 \pm 0,75$ & $7,15 \pm 0,66$ & $7,08 \pm 0,82$ \\
\hline тыс / мM $^{3}$ & 4 & $6,00 \pm 0,79$ & $6,54 \pm 0,45$ & $6,22 \pm 0,48$ & $6,31 \pm 0,70$ \\
\hline Гемоглобин, & 2 & $8,77 \pm 4,15$ & $9,15 \pm 2,22$ & $9,46 \pm 1,15$ & $9,91 \pm 3,34$ \\
\hline$\Gamma \backslash 100 \mathrm{мл}$ & 4 & $11,22 \pm 3,33$ & $14,23 \pm 4,01$ & $14,44 \pm 3,56$ & $14,21 \pm 3,89$ \\
\hline
\end{tabular}

${ }^{\mathrm{x}}-\mathrm{P}>0,95 ;{ }^{\mathrm{xx}}-\mathrm{P}>0,99 ;{ }^{\mathrm{xxx}}-\mathrm{P}>0,999$

Введение в рацион щенят лисиц ПАБК способствовало усилению гемоэритропоэтических функций крови. Число эритроцитов уже в 2 
месячном возрасте в опытных группах было больше, чем в контрольной группе на 0,23-0,47 млн./мм² . К концу эксперимента эта разница уже составила 0,25-0,49млн/мм³ (или на 2,82-5,54\%) . Концентрация гемоглобина в крови щенков опытных групп на 4,33-12,99 \% превышала таковой показатель у щенков контрольной группы в 2 месячном возрасте, в 4 месячном возрасте превышение составило 7,48-9,22\%. Выявленное повышение общего количества эритроцитов и гемоглобина в крови молодняка лисиц опытных групп дает основание полагать, что введение в рацион ПАБК положительно влияет на кроветворную функцию организма.

По мнению ряда авторов (С.С.Семенов, 1990; Е.В.Эйдригевич, 1978, 1969) большое количество эритроцитов и гемоглобина в крови свидетельствует о высоком уровне обмена веществ.

В организме животных, как было доказано ранее, лейкоциты носят защитную функцию. Поэтому, исходя из количества в крови этих кровяных телец, можно косвенно судить о состоянии самого организма. Данные, полученные в нашем исследовании по содержанию лейкоцитов в крови подопытных щенят, показали на наличие неплохих результатов по этому показателю.

По содержанию в крови лейкоцитов щенята опытных групп уже в 2месячном возрасте превосходили щенят контрольной группы на 0,100,31 тыс/мм ${ }^{3}$ или на $1,46-4,53 \%$. В 4-месячном возрасте количество лейкоцитов в крови щенят опытной и контрольных групп несколько уменьшилось, но было в пределах физиологических норм. Следует также отметить, что количество лейкоцитов у щенят опытных групп было больше, чем - контрольной группы на 3,66-9,0\%.

По мнению В.И. Степанова (1973) и В.С. Федина (1974) количество лейкоцитов в крови может служить показателем устойчивости организма к влиянию внешней среды. В то же время их низкое содержание связано с низкой резистентностью организма животных. 
Как видно из данных, приведенных в таблице 7 и 11, молодняк контрольной группы характеризовался не только самыми низкими показателями живой массы, но и самым низким гематологическим статусом.

Следует отметить, что в исследуемых группах щенят лисиц все показатели крови находились в пределах физиологических норм.

Известно, что интенсивность протекающих в организме химических реакций определяется, главным образом, белковыми веществами крови.

Роль белков крови заключается в транспортировке питательных веществ во все части организма, они выполняют защитную и регуляторные функции. Любое внешнее воздействие на организм сопровождается определенным изменением соотношения белковых фракций крови. Поэтому белковый состав крови может служить важным физиологическим показателем состояния организма. По белковому составу можно изучить глубокие изменения, происходящие в организме: его реактивную способность, рост и развитие молодняка, продуктивные качества и т.д. Количества белка и его фракций в сыворотке крови могут меняться под влиянием целого ряда факторов. По данным различных исследователей (П.А.Есков, В.А. Ли, 1964; К.П. Макурин, 1964; П.Е. Ладан, Н.Н. Белкина, 1964; И.А. Савич, Н.С. Акопян, 1971) у животных скороспелых пород в сыворотке крови содержится белка больше, чем у животных менее скороспелых пород.

Поэтому при изучении механизма действия БАВ - адаптогенов определенный интерес представляет выяснение состояния белкового обмена. Биохимические показатели крови отражают интенсивность обменных процессов в организме и связаны с его ростом и развитием (М.В Саликова,1979; А.Д.Антипов,1987; Н.Н. Подлетская, 1973; И.Ф. Рось,1973; Е.В...Эйдригевич,1957, 1969).

Белковый состав крови зверей, получавших адаптоген ПАБК свидетельствует об улучшении общего физиологического состояния их организма (табл. 12). Биохимический анализ крови показал, что содержание 
общего белка и соотношение белковых фракций в сыворотке крови изменялись по мере роста животных. Действие ПАБК на белковый состав крови проявилось в повышении количества общего белка за счет глобулиновых фракций и в тенденции уменьшения концентрации альбуминов, что связано, очевидно, с усиленным ростом щенят, получавших ПАБК и большим расходованием альбумина для синтеза белков органов и тканей (А.Д. Антипов, 1987).

В сыворотке крови животных опытных групп уровень общего белка был выше на 0,10-0,32г/100мл или на 1,99-6,37\% в 2 месячном возрасте, и на 0,02$0,20 \Gamma / 100$ мл или на $0,33-3,33 \%$ - в 4 месячном возрасте. Увеличение уровня общего белка шло за счет глобулиновых фракций ( $>0,99$ у самцов). Абсолютное содержание альбуминов в опытных группах было меньше, чем в контрольной. В соответствии с этим и белковый коэффициент в опытных группах был меньше. В возрасте 2 месяцев у щенят опытных групп данный коэффициент был равен 1,47-1,68, тогда как в контрольной группе -1,70.

В 4-месячном возрасте количество альбуминов продолжило снижаться: белковый коэффициент в опытных группах равнялся 1,33-1,50 (в контрольной группе -1,54).

Различное функциональное и физиологические состояние организма связано как с существованием разнообразных по своим функциям белков, так и с их количеством. Роль отдельных белков в организме различна. Так, транспортную функцию при удалении из организма ядовитых веществ и регуляцию коллоидно-осмотического давления выполняют альбумины. Они имеют определенное значение как резервный белок. $\alpha$ - глобулины в основном участвуют в переносе липидов, жиров и сахаров; $\beta$ - глобулиновая фракция выполняет антитоксическую функцию. Увеличение $\gamma$ глобулиновой фракции является показателем высокой резистентности организма. 
Из литературных данных известно, что при положительной стимуляции вместе с увеличением количества общего белка и уменьшением количества альбуминов, в крови наблюдается повышение уровня гамма-глобулинов. Это является отражением иммунобиологических реакций и свидетельствует о повышении общей резистентности организма у подопытных зверей.

Результаты наших исследований согласуются с работами ряда ученых (Е.П.Данилов, 1978; Р.Г.Дубова, 1973; 1975; Е.В.Эйдригевич, 1957). В нашем опыте увеличение концентрации глобулинов у щенят опытных групп происходило за счет гамма-глобулиновой фракции и составила в 2месячном возрасте $11,12-12,56 \%$, в контрольной группе 7,88\% ( $\mathrm{P}>0,95)$, в 4-месячном возрасте $\gamma$ - глобулинов было больше в опытных группах на $0,42-1,73 \%$.

Сравнение результатов биохимических и морфологических исследований крови опытной и контрольной групп показывает, что содержание форменных элементов крови, общего белка, его фракций в опытных группах было больше, чем в контрольной.

Проведенные исследования морфологического и биохимического состава крови свидетельствует о том, что все показатели по группам зверей не выходили за пределы клинических норм для молодняка лисиц данного возраста. В целом подопытные щенки лисиц отличались хорошим состоянием здоровья, у них не было патологических изменений картины крови.

Для разработки более эффективных методов управления процессом развития животных, в частности лисиц, Э.И. Обертас (1972) считает, что необходимо знать не только общие закономерности индивидуального развития, но и располагать данными об особенности роста их внутренних органов и систем. 
Таблица 12

Содержание общего белка и его фракций в сыворотке крови молодняка лисиц, $\mathrm{n}=4$

\begin{tabular}{|l|c|c|c|c|c|}
\hline \multicolumn{1}{|c|}{ Показатели } & Возраст, & \multicolumn{4}{|c|}{ Группы } \\
\cline { 3 - 6 } & мес & I к. & II o. & Ш o. & $1 \mathrm{~V}$. \\
\hline Общий белок, & 2 & $5,02 \pm 3,19$ & $5,12 \pm 1,28$ & $5,21 \pm 1,83$ & $5,34 \pm 2,12$ \\
г/100мл & 4 & $5,99 \pm 1,34$ & $6,17 \pm 1,35$ & $6,01 \pm 0,94$ & $6,19 \pm 1,35$ \\
Альбумины, \% & 2 & $63,22 \pm 1,10$ & $62,40 \pm 1,10$ & $60,73 \pm 1,88$ & $59,06 \pm 3,44$ \\
& 4 & $60,15 \pm 2,39$ & $59,22 \pm 1,68$ & $59,18 \pm 1,32$ & $57,01 \pm 3,01$ \\
Глобулины, \% & 2 & $36,14 \pm 1,10$ & $37,14 \pm 1,10$ & $38,58 \pm 1,88$ & $40,06 \pm 3,44$ \\
& 4 & $39,03 \pm 2,39$ & $40,71 \pm 1,68$ & $39,91 \pm 1,32$ & $42,70 \pm 3,01$ \\
А/Г & 2 & $1,70 \pm 0,12$ & $1,68 \pm 0,13$ & $1,64 \pm 0,22$ & $1,47 \pm 0,31$ \\
\multirow{2}{\alpha}{-глобулин, \% } & 2 & $1,54 \pm 0,24$ & $1,45 \pm 0,17$ & $1,50 \pm 0,11$ & $1,33 \pm 0,20$ \\
& 4 & $10,01 \pm 0,91$ & $8,32 \pm 1,19$ & $8,08 \pm 1,68$ & $8,58 \pm 1,65$ \\
$\beta$ - глобулин. \% & 2 & $11,12 \pm 1,32$ & $12,11 \pm 0,94$ & $12,01 \pm 0,70$ & $12,16 \pm 4,52$ \\
& 4 & $19,25 \pm 0,85$ & $17,70 \pm 1,22$ & $17,62 \pm 0,62$ & $18,92 \pm 0,64$ \\
$\gamma$ - глобулин,\% & 2 & $7,88 \pm 1,95$ & $11,12 \pm 1,18$ & $11,88 \pm 1,49$ & $16,05 \pm 1,22$ \\
& 4 & $12,76 \pm 1,49$ & $13,98 \pm 0,62$ & $13,18 \pm 1,04$ & $12,56 \pm 1,82$ \\
& & & & & $14,49 \pm 1,65$ \\
\hline
\end{tabular}


С целью изучения влияния ПАБК на развитие внутренних органов подопытных щенят лисиц нами, после их убоя, извлекались их сердце, легкие, печень, почки, желудок и кишечник. Рост этих органов определяли путем взвешивания и измерения. Материалы проведенных исследований приведены в таблице 13.

Таблица 13

Масса внутренних органов и длина кишечника подопытных щенят лисиц

\begin{tabular}{|l|c|c|c|c|}
\hline \multirow{2}{*}{$\begin{array}{l}\text { Наимено } \\
\text { вание }\end{array}$} & \multicolumn{4}{|c|}{ Группы } \\
\cline { 3 - 5 } Сердце, г & $48,00 \pm 1,40$ & $48,12 \pm 1,67$ & $50,00 \pm 1,58$ & $47,87 \pm 1,29$ \\
Легкие, г & $47,00 \pm 1,54$ & $46,25 \pm 1,54$ & $50,00 \pm 1,49$ & $47,50 \pm 1,39$ \\
Печень, г & $136,05 \pm 3,27$ & $135,75 \pm 3,78$ & $139,75 \pm 4,39$ & $136,25 \pm 4,47$ \\
Желудок, г & $37,87 \pm 1,56$ & $40,62 \pm 1,23$ & $40,00 \pm 1,39$ & $38,75 \pm 1,39$ \\
Почки, г & $48,37 \pm 1,43$ & $50,62 \pm 2,28$ & $51,75 \pm 1,93$ & $50,00 \pm 1,35$ \\
Длина & $237,62 \pm 2,65$ & $238,62 \pm 2,38$ & $241,25 \pm 4,91$ & $239,87 \pm 3,34$ \\
кишечника & & & & \\
см & & & & \\
\hline
\end{tabular}

${ }^{\mathrm{x}}-\mathrm{P}>0,95 ;{ }^{\mathrm{xx}}-\mathrm{P}>0,99 ;{ }^{\mathrm{xxx}}-\mathrm{P}>0,999$

В наших исследованиях по массе легких опытные группы были выше контрольной на 0,5-3,0г или на 1,06-6,38 \% .

По массе почек опытные группы превышали контрольную на 1,63-3,38г или на 3,36-6,98\% $(\mathrm{P}>0,95)$.

Печень участвует в процессах пищеварения, поддержания постоянства 
внутренней среды организма.

По массе печень щенков опытных групп была больше, чем у щенят контрольной группы на 0,2-3,7 г или на 0,14-2,71\%.

Мы полагаем, что ПАБК способствовало улучшению вышеуказанных процессов, а значит повышалась жизнеспособность щенков-гипотрофиков.

Анализ полученных результатов позволяет заключить, что внутренние органы зверей опытных групп, по сравнению с отстающими в росте щенятами контрольной группы, были развиты значительно лучше (таблица 13). Опытами Ю.К. Свечина, Н.Н. Борисовой (1988), Ю.К. Свечина, Н.Н. Михеевой (1990), Spencer S., Hull D. (1984) установлено, что интенсивность роста основных тканей совпадает с интенсивностью роста всех органов. Это наблюдалось и в наших исследованиях. Из таблицы 13 также видно, что у щенят опытных групп по сравнению с щенятами контрольной группы, отмечалось некоторое увеличение массы внутренних органов.

Одновременно были взяты промеры длины кишечника у щенят опытных и контрольной групп. Было отмечено, что по сравнению с контрольной группой, состоящей из отстающих в росте щенят, длина кишечника у особей опытных групп была больше на 1,09-3,63см или на 0,45-1,52 \%.

Как свидетельствуют полученные нами результаты подопытные животные при добавлении ПАБК в рацион имели различия по развитию внутренних органов.

Анализ массы внутренних органов подопытных щенков лисиц (таблица 13) позволяет констатировать, что щенки-гипотрофики, не получавшие ПАБК, имели наименьшую массу сердца, легких, печени, селезенки, почек и желудка. Стимуляция роста и развития щенков путем использования парааминобензойной кислоты повлияла и на развитие органов кровообращения, дыхательной и выделительной систем.

Следует отметить, что масса внутренних органов подопытных щенков находилась в прямопропорциональной зависимости с массой тела. Это 
объясняется, по-видимому, тем, что у животных опытных групп обмен веществ проходил интенсивнее, а поэтому и органы, регулирующие этот обмен, были развиты лучше, чем у отстающих в росте щенков лисиц контрольной группы.

Е.В. Эйдригевич, В.В. Раевская (1978) установили, что степень вентиляции легких и их размер имеют прямую связь с интенсивностью роста животных и их продуктивностью.

В нашем исследовании щенки опытных групп, имея большую массу органов пищеварения и их линейные размеры, лучше использовали корма рациона, давали большие среднесуточные приросты живой массы по сравнению с отстающими в росте аналогами из контрольной группы.

При вскрытии тушек патологических изменений внутренних органов в опытных группах не отмечено. Печень, почки и селезенка по величине, цвету и консистенции были в пределах нормы.

Гистологические исследования печени, почек и селезенки свидетельствуют об отсутствии в них патологических изменений.

В печени щенят опытных групп жиро-белковая дистрофия гипотоцитов менее выражена и сосуды триад печени (желчный проток, вена, артерия) у всех щенят были без каких-либо изменений. В почках у щенят опытных и контрольной групп различий в строении не выявлено В лимфатических фолликулах селезенки у щенят опытных групп наблюдалась различная концентрация клеточных центров размножения: в контрольной группе не выражены, в опытных группах - реактивные центры размножения выражены. Это отражает различную иммунологически реакцию селезенки на различные адаптогены в зависимости от группы зверей. Данные наших исследований согласуются с работами А..Хэм, Д.Кормак (1983), где указано, что лимфатические фолликулы селезенки отражают состояние гуморального иммунитета.

Большое количество лимфатических фолликулов с выраженными 
Таблица 14

Результаты бонитировки подопытных лисиц в баллах

\begin{tabular}{|c|c|c|c|c|c|c|c|c|}
\hline Группы & $\mathrm{n}$ & $\begin{array}{c}\text { Размер и } \\
\text { телосложение }\end{array}$ & $\begin{array}{l}\text { Качество } \\
\text { опушения }\end{array}$ & $\begin{array}{c}\text { Окрас } \\
\text { волосяного } \\
\text { покрова }\end{array}$ & $\mathrm{n}$ & $\begin{array}{c}\text { Размер и } \\
\text { телосложение }\end{array}$ & $\begin{array}{l}\text { Качество } \\
\text { опушения }\end{array}$ & $\begin{array}{c}\text { Окрас } \\
\text { волосяного } \\
\text { покрова }\end{array}$ \\
\hline & \multicolumn{4}{|c|}{ Самки } & \multicolumn{4}{|c|}{ Самцы } \\
\hline $1 \kappa$. & 5 & $3,37 \pm 0,49$ & $4,16 \pm 0,18$ & $3,50 \pm 0,20$ & 4 & $3,33 \pm 0,23$ & $4,33 \pm 0,23$ & $4,50 \pm 0,22$ \\
\hline По. & 6 & $3,47 \pm 0,30^{x}$ & $4,50 \pm 0,24$ & $3,86 \pm 0,21$ & 5 & $3,50 \pm 0,43$ & $4,50 \pm 0,22$ & $4,66 \pm 0,21$ \\
\hline Ш о. & 6 & $3,71 \pm 0,37^{x}$ & $4,45 \pm 0,46$ & $3,71 \pm 0,16$ & 8 & $3,83 \pm 0,28^{x}$ & $4,62 \pm 0,18$ & $4,87 \pm 0,13$ \\
\hline $1 \mathrm{Y} o$. & 5 & $3,67 \pm 0,33^{\mathrm{x}}$ & $4,66 \pm 0,40$ & $4,06 \pm 0,21$ & 6 & $3,73 \pm 0,40$ & $4,57 \pm 0,21$ & $4,71 \pm 0,19$ \\
\hline
\end{tabular}

${ }^{\mathrm{x}}-\mathrm{P}>0,95 ;^{\mathrm{xx}}-\mathrm{P}>0,99 ; ;^{\mathrm{xx}}-\mathrm{P}>0,999$ 
центрами размножения указывает на напряженный гуморальный иммунитет.

Проведенные нами морфологические и гистологические исследования свидетельствуют о том, что скармливание ПАБК вызвало у щенят опытных групп некоторое увеличение сердца, легких, печени, почек, желудка, а также длины кишечника, но в пределах физиологической нормы. Гистологическими исследованиями не выявлено патологических изменений во внутренних органах щенят подопытных групп. Было отмечено улучшение состояния гуморального иммунитета у щенят опытных групп.

Следовательно добавка ПАБК в корм молодняка лисиц не вызывает какихлибо отрицательных изменений во внутренних органах, о чем свидетельствуют результаты гистологических исследований.

Оценка продуктивных и племенных качеств контрольной и опытной групп щенят проводилась путем их бонитировки. Ее проводили по бонитировочному ключу (требованию), в соответствии с "Инструкцией по бонитировке пушных зверей" (1986, В.А.Берестов, 1985). При оценке зверей, особое внимание обращали на густоту, упругость и уравненность волосяного покрова. Обязательно учитывали и зонарность окраски пуха, поскольку коричневые кончики пуховых волос придают буроватый оттенок всему опушению.

Бонитировали всех щенят опытной и контрольной групп. Результаты бонитировки представлены в таблице 14. Анализ полученных данных показывает, что вследствие повышенной живой массы к моменту бонитировки щенята опытных групп получили за размер и телосложение балл значительно выше, чем щенята контрольной группы, не получавшие ПАБК.

У подопытных щенят, по сравнению с щенятами контрольной группы, средний балл за этот показатель был больше у самок на 2,96-10,08\%; у самцов - на 5,10-12,01\%.

За качество опушения и окраску волосяного покрова щенята опытных 
групп также получили выше балл, но разница была недостоверна.

По итогам оценки размера и телосложения, качества опушения и окраски волосяного покрова был определен класс каждого щенка. В результате такой оценки классность щенят опытных групп была выше, чем контрольной группы.

Результаты бонитировки позволяют сделать вывод, что введение в рацион парааминобензойной кислоты отстающим в росте щенятам лисиц положительно отразилось на их продуктивных показателях.

Таблица 15

Размер шкурок молодняка лисиц, $\mathrm{n}=4$

\begin{tabular}{|c|c|c|c|}
\hline Группы & Пол & Длина шкурок, см & Площадь шкурок, см² \\
\hline \multirow[t]{2}{*}{ I к. } & q & $80,25 \pm 1,54$ & $2006,25 \pm 38,69$ \\
\hline & $\hat{0}$ & $81,20 \pm 1,01$ & $2030,00 \pm 28,50$ \\
\hline \multirow[t]{2}{*}{ II o. } & q & $81,75 \pm 0,85$ & $20,43,75 \pm 21,34$ \\
\hline & $\widehat{0}$ & $82,25 \pm 0,85$ & $2056,25 \pm 21,34$ \\
\hline \multirow[t]{2}{*}{ Ш о. } & q & $84,75 \pm 0,47^{x}$ & $2118,75 \pm 11,96^{\mathrm{x}}$ \\
\hline & $\widehat{0}$ & $85,25 \pm 0,62^{x}$ & $2131,25 \pm 15,72^{\mathrm{X}}$ \\
\hline \multirow[t]{2}{*}{$1 \mathrm{~V}$ o. } & q & $82,50 \pm 0,64$ & $20,62,50 \pm 16,13$ \\
\hline & $0^{\lambda}$ & $83,00 \pm 0,40$ & $2075,00 \pm 10,20$ \\
\hline
\end{tabular}

После первичной обработки шкурки подопытных щенят опытной и контрольной групп сортировали в соответствии с требованиями ГОСТа 790778. В соответствии с этим ГОСТ-ом шкурки щенят контрольной и опытной групп подразделялись по размеру, цвету, сорту и группам дефектов.

Анализ полученных данных свидетельствует о том, что длина и площадь шкурок у щенят опытных групп были несколько выше по сравнению с таковыми в контрольной группе. Длина шкурки самок 
опытных групп была больше на 1,86-5,6\%, самцов - на 1,29-4,98\% (P>0,99), a площадь шкурки была больше соответственно на $36,75-112,5 \mathrm{~cm}^{2}$ и 26,25$101,25 \mathrm{~cm}^{2}$ (у самцов $\mathrm{P}>0,95$ ).

Таблица 16

Качественные показатели шкурок лисиц контрольных и опытных групп

\begin{tabular}{|c|c|c|c|c|c|c|}
\hline \multirow{2}{*}{ Группы } & \multicolumn{5}{|c|}{ Количество и удельная масса шкурок } \\
\cline { 2 - 7 } & нормальных & \multicolumn{3}{|c|}{ Малый дефект } & Средний дефект \\
\cline { 2 - 7 } & & $\%$ & шт. & $\%$ & шт. & $\%$ \\
\hline I к. & 4 & 50,00 & 2 & 25,00 & 2 & 25,00 \\
II о. & 3 & 37,50 & 4 & 50,00 & 1 & 12,50 \\
Ш о. & 4 & 50,00 & 3 & 37,50 & 1 & 12,50 \\
IV o. & 5 & 62,50 & 1 & 12,50 & 2 & 25,00 \\
\hline
\end{tabular}

По степени дефектности волосяного покрова шкурки подопытных щенят были несколько лучше, чем шкурки щенят контрольной группы, состоящей из отстающих в развитии зверей. Состояние качества шкурок лисиц по дефектности представлено в таблице 16. Нормальных шкурок среди зверей 1 У опытной группы было на 12,5\% больше, с малым дефектом на 25,00\% во П группе больше, чем в контрольной группе.

Товароведческая оценка шкурок показала, что основными дефектами в опытной и контрольной группах были - сеченость и разреженность волос на животе и огузке, поредение ости на боках.

Данные, характеризующие общие показатели качества (зачет на голову) и цены шкурок лисиц опытной и контрольной групп, представлены в таблице 17. Зачет по качеству шкурок в контрольной составлял 64,28\%, в опытных группах - 64,37-65,28\%. Это отразилось на стоимости шкурковой продукции контрольной и опытной групп. Средняя стоимость шкурковой 
Таблица 17

Зачет по качеству и цена шкурок контрольной и опытных групп лисиц

\begin{tabular}{|l|c|c|}
\hline \multirow{2}{*}{ Группа } & \multicolumn{2}{|c|}{ В среднем по группе } \\
\cline { 2 - 3 } & Зачет по качеству,\% & Ср. цена, руб \\
\hline К. & 64,28 & 1607,00 \\
П о. & 64,37 & 1609,25 \\
Ш о. & 65,28 & 1632,00 \\
1 У о. & 64,73 & 1618,25 \\
& & \\
\hline
\end{tabular}

продукции в опытных группах составила 1609,25-1632,00 руб, что больше чем в контрольной группе на 2,0-25,0руб.

Исходя из вышеизложенного следует отметить, что введение парааминобензойной кислоты в рацион лисиц положительно повлияло на хозяйственно-полезные признаки гипотрофичного молодняка, лучшие результаты были получены при введении ПАБК в дозе 1,0мг на 1кг живой массы на 1 голову.

Значительно больший экономический эффект был получен при введении им в корм 1,0 мг парааминобензойной кислоты на 1 кг живой массы с 40 дня жизни, на каждой шкурке получено дополнительной прибыли 25,00 руб. 


\subsection{2. Влияние сукцината хитозана на рост и развитие гипотрофичного молодняка лисиц}

Анализ результатов исследования, проведенного в рассматриваемом опыте свидетельствует о том, что сукцинат хитозана положительно повлиял на живую массу, длину тела и обхват груди подопытных щенятгипотрофиков. К концу опыта живая масса самочек опытных групп превосходила аналогов контрольной группы на 0,14-0,31 кг или на 4,199,28 \%, а самцов - на 0,06-0,17 кг или на 1,67-4,73\% (достоверность у самок и самцов - $\mathrm{P}>0,95$ ).

Анализ сравнительных данных линейных промеров свидетельствует о том, что, как и в опыте с парааминобензойной кислотой они находились в прямо пропорциональной зависимости от живой массы щенят.

По длине тела и обхвату груди в 4-месячном возрасте щенята опытных групп превосходили щенят контрольной группы. Самки опытных групп были длиннее на 1,5-3,28 см или на 3,12-6,83 \%, самцы - на 1,743,75 см или на $3,52-7,60 \%$. Разница достоверна по длине тела у самцов $(\mathrm{P}>0,999)$.

Из таблицы 18 также видно, что по обхвату груди к концу опыта щенята опытных групп превосходили щенят контрольной группы. Объем груди самок был больше на 0,48-2,67cм или на $1,5-8,34 \%$, самцов - на 0,57-2,47см или на $1,71-7,42 \%$.

На основании расчетов установлено, что среднесуточные приросты массы самок и самцов опытных групп (таблица 19) были выше, чем в контрольной группах. О повышенной энергии роста щенят в этих группах свидетельствуют также показатели относительного прироста их живой массы. Из таблицы 19 видно, что относительный прирост живой массы у опытных щенят больше, чем в контрольной группах. Среднесуточный прирост живой массы самок щенят лисиц опытных групп больше на 1,4-3,4 г 
или 4,82-11,72\%, чем в контрольной группах, самцов - соответственно 0,81,9 г и 2,53-6,03\%. Относительный прирост живой массы за весь период опыта у самок опытных групп больше на 13-44\%, у самцов на 15-23\%.

Таблица 19

Абсолютный среднесуточный и относительный приросты живой массы лисиц в подопытных группах

\begin{tabular}{|c|c|c|c|c|c|}
\hline \multirow[t]{2}{*}{ Показатели } & \multirow[b]{2}{*}{ Пол } & \multicolumn{4}{|c|}{ Группы } \\
\hline & & $\begin{array}{l}1 \\
\text { к. }\end{array}$ & $\begin{array}{l}\text { П } \\
\text { o. }\end{array}$ & $\begin{array}{c}\text { Ш } \\
\text { o. }\end{array}$ & $\begin{array}{l}1 \mathrm{Y} \\
0 .\end{array}$ \\
\hline Абсолютный & q & 29,0 & 30,4 & 32,4 & 32,1 \\
\hline $\begin{array}{l}\text { среднесуточный } \\
\text { прирост, Г }\end{array}$ & $\hat{0}$ & 31,5 & 32,3 & 33,4 & 32,6 \\
\hline Относительный & q & 357 & 370 & 400 & 401 \\
\hline $\begin{array}{l}\text { прирост живой } \\
\text { массы, \% }\end{array}$ & $\hat{0}$ & 378 & 393 & 401 & 397 \\
\hline
\end{tabular}

Весовой индекс у зверей опытных групп в 4-месячном возрасте был выше у самок на 0,08-0,18\% по сравнению с контрольной группой.

Материалы по отходу и сохранности щенят в группах представлены в таблице 21. Из данных этой таблицы видно, что сохранность щенят в опытных группах была выше, чем в контрольной группах. Так, отход щенков до регистрации в опытных группах был на 5-15\% меньше, чем в контрольной группе. К концу опыта количество павших щенков в контрольной группе было больше, чем в опытных на 10-15\%. Это отразилось на сохранности молодняка. К 4-месячному возрасту в опытных группах сохранилось на 20-35\% животных больше, чем в контрольной, где щенки не получали сукцинат хитозана. 
Влияние CX на сохранность подопытных щенят лисиц

\begin{tabular}{|c|c|c|c|c|c|c|c|}
\hline \multirow[t]{2}{*}{ Группы } & \multirow[t]{2}{*}{$\mathrm{n}$} & \multicolumn{2}{|c|}{$\begin{array}{c}\text { Отход щенят } \\
\text { на день } \\
\text { регистрации }\end{array}$} & \multicolumn{2}{|c|}{$\begin{array}{l}\text { Отход щенят } \\
\text { после } \\
\text { регистрации }\end{array}$} & \multirow{2}{*}{$\begin{array}{c}\text { Количество } \\
\text { щенят, } \\
\text { голов }\end{array}$} & \multirow[t]{2}{*}{$\begin{array}{l}\text { Сохран- } \\
\text { ность, \% }\end{array}$} \\
\hline & & $\mathrm{n}$ & $\%$ & $\mathrm{n}$ & $\%$ & & \\
\hline 1 к. & 20 & 6 & 30 & 6 & 30 & 8 & 40 \\
\hline П о. & 20 & 5 & 25 & 3 & 15 & 12 & 60 \\
\hline Ш о. & 20 & 3 & 15 & 2 & 10 & 15 & 75 \\
\hline $1 \mathrm{y}$ o. & 20 & 4 & 20 & 3 & 15 & 13 & 65 \\
\hline
\end{tabular}

В целом подопытные щенки отличались хорошим состоянием здоровья, без каких-либо патологических изменений. Повышение жизнеспособности и увеличение скорости роста щенков-гипотрофиков опытных групп согласуются с укреплением их физиологического статуса, о чем свидетельствует достоверное увеличение показателей красной крови.

Меньший отход и более высокая сохранность щенят в опытных группах по сравнению с контрольной группой обусловлены, очевидно, положительным влиянием сукцината хитозана на организм этих животных.

Полученные в наших опытах данные свидетельствуют о том, что применение сукцината хитозана дает возможность в процессе выращивания значительно улучшить показатели роста и развития щенков, родившихся слабыми и с малой живой массой. Повышается и резистентность животных, о чем свидетельствует повышение их сохранности и делового выхода. Анализ полученных в этом эксперименте данных подтверждает закономерности, установленные Н.П. Чирвинским и А.А. Малигоновым о 
Таблица 18

Динамика живой массы, длины тела и обхвата груди подопытного молодняка лисиц

\begin{tabular}{|c|c|c|c|c|c|c|}
\hline \multirow[t]{2}{*}{ Показатели } & \multirow{2}{*}{$\begin{array}{l}\text { Воз- } \\
\text { раст, } \\
\text { мес }\end{array}$} & \multirow[b]{2}{*}{ Пол } & \multicolumn{4}{|c|}{ Группы } \\
\hline & & & $\begin{array}{c}1 \\
\kappa .\end{array}$ & $\begin{array}{l}\Pi \\
\text { o. }\end{array}$ & $\begin{array}{l}Ш \\
\text { о. }\end{array}$ & $\begin{array}{c}\text { IV } \\
\text { o. }\end{array}$ \\
\hline \multirow[t]{4}{*}{ Живая масса, кг } & \multirow[t]{2}{*}{1} & q & $0,73 \pm 0,04$ & $0,74 \pm 0,05$ & $0,73 \pm 0,04$ & $0,72 \pm 0,05$ \\
\hline & & $\sigma^{\pi}$ & $0,75 \pm 0,03$ & $0,74 \pm 0,05$ & $0,75 \pm 0,03$ & $0,74 \pm 0,04$ \\
\hline & \multirow[t]{2}{*}{4} & q & $3,34 \pm 0,07$ & $3,48 \pm 0,06$ & $3,65 \pm 0,04$ & $3,61 \pm 0,08$ \\
\hline & & $\delta$ & $3,59 \pm 0,08$ & $3,65 \pm 0,09$ & $3,76 \pm 0,05$ & $3,68 \pm 0,07$ \\
\hline \multirow[t]{4}{*}{ Длина тела, см } & \multirow[t]{2}{*}{1} & q & $27,69 \pm 0,39$ & $28,07 \pm 0,17$ & $27,63 \pm 0,21$ & $27,98 \pm 0,47$ \\
\hline & & o & $27,82 \pm 0,48$ & $28,38 \pm 0,21$ & $27,74 \pm 0,16$ & $28,46 \pm 0,33$ \\
\hline & \multirow[t]{2}{*}{4} & q & $47,98 \pm 0,42$ & $49,48 \pm 0,38$ & $51,26 \pm 0,25$ & $50,69 \pm 0,46$ \\
\hline & & $\sigma^{\pi}$ & $49,33 \pm 0,36$ & $51,07 \pm 0,29$ & $53,08 \pm 0,16$ & $52,68 \pm 0,39$ \\
\hline \multirow[t]{4}{*}{ Обхват груди, см } & \multirow[t]{2}{*}{1} & q & $17,86 \pm 0,41$ & $18,15 \pm 0,53$ & $17,41 \pm 0,49$ & $17,87 \pm 0,25$ \\
\hline & & $\sigma^{\lambda}$ & $18,04 \pm 0,27$ & $18,28 \pm 0,48$ & $17,93 \pm 0,37$ & $18,22 \pm 0,15$ \\
\hline & \multirow[t]{2}{*}{4} & q & $31,99 \pm 0,44$ & $32,47 \pm 0,24$ & $34,66 \pm 0,21$ & $33,59 \pm 0,39$ \\
\hline & & $\sigma^{\lambda}$ & $33,27 \pm 0,38$ & $33,84 \pm 0,43$ & $35,74 \pm 0,45$ & $34,17 \pm 0,34$ \\
\hline
\end{tabular}

${ }^{\mathrm{x}}-\mathrm{P}>0,95 ;{ }^{\mathrm{xx}}-\mathrm{P}>0,99 ;{ }^{\mathrm{xxx}}-\mathrm{P}>0,999$ 
Таблица 20

Индексы телосложения лисиц разных групп

\begin{tabular}{|c|c|c|c|c|c|c|}
\hline \multirow[t]{3}{*}{ Показатели } & \multirow{3}{*}{$\begin{array}{l}\text { Воз- } \\
\text { раст, } \\
\text { мес }\end{array}$} & \multirow{3}{*}{ Пол } & \multicolumn{4}{|c|}{ Группы } \\
\hline & & & 1 & $\Pi$ & Ш & $1 \mathrm{y}$ \\
\hline & & & к. & o. & o. & o. \\
\hline Весовой индекс, & 1 & $\bar{q}$ & $2,63 \pm 0,02$ & $2,62 \pm 0,05$ & $2,63 \pm 0,04$ & $2,56 \pm 0,04$ \\
\hline$\%$ & & $0^{\pi}$ & $2,68 \pm 0,05$ & $2,59 \pm 0,04$ & $2,69 \pm 0,06$ & $2,58 \pm 0,05$ \\
\hline & 4 & q & $6,94 \pm 0,04$ & $7,04 \pm 0,08$ & $7,12 \pm 0,04$ & $7,11 \pm 0,09$ \\
\hline & & $\sigma^{\pi}$ & $7,21 \pm 0,08$ & $7,12 \pm 0,09$ & $6,98 \pm 0,21$ & $6,89 \pm 0,14$ \\
\hline & 1 & q & $64,48 \pm 0,37$ & $64,63 \pm 1,17$ & $62,88 \pm 0,84$ & $63,78 \pm 0,91$ \\
\hline Индекс & & $\sigma^{\lambda}$ & $64,81 \pm 0,44$ & $64,39 \pm 0,84$ & $64,59 \pm 0,85$ & $63,99 \pm 0,83$ \\
\hline сбитости, \% & 4 & q & $66,65 \pm 0,51$ & $65,58 \pm 0,49$ & $67,48 \pm 0,38$ & $65,85 \pm 0,69$ \\
\hline & & $\sigma^{\pi}$ & $67,39 \pm 0,69$ & $66,19 \pm 0,54$ & $67,29 \pm 0,54$ & $64,77 \pm 0,43$ \\
\hline
\end{tabular}


Содержание общего белка и фракций в сыворотке крови молодняка лисиц, $\mathrm{n}=4$

\begin{tabular}{|l|c|c|c|c|c|}
\hline \multicolumn{1}{|c|}{ Показатели } & Возраст, & \multicolumn{4}{|c|}{ Группы } \\
\cline { 3 - 6 } & мес & I к. & II o. & Ш o. & $1 \mathrm{~V}$ o. \\
\hline Общий белок, & 2 & $5,13 \pm 2,64$ & $5,27 \pm 1,21$ & $5,39 \pm 1,87$ & $5,28 \pm 2,23$ \\
Г/100мл & 4 & $5,87 \pm 1,27$ & $6,31 \pm 1,26$ & $6,25 \pm 1,28$ & $6,09 \pm 1,25$ \\
Альбумины, \% & 2 & $63,09 \pm 1,35$ & $62,11 \pm 1,18$ & $61,18 \pm 1,70$ & $61,06 \pm 3,27$ \\
& 4 & $60,31 \pm 2,16$ & $58,43 \pm 1,49$ & $60,84 \pm 2,72$ & $59,54 \pm 3,21$ \\
Глобулины, \% & 2 & $35,61 \pm 1,42$ & $35,76 \pm 1,08$ & $38,21 \pm 1,70$ & $37,76 \pm 3,24$ \\
& 4 & $38,13 \pm 2,09$ & $37,83 \pm 1,45$ & $38,57 \pm 2,72$ & $38,21 \pm 2,87$ \\
А/Г & 2 & $1,68 \pm 0,34$ & $1,71 \pm 0,26$ & $1,60 \pm 0,19$ & $1,59 \pm 0,23$ \\
& 4 & $1,57 \pm 0,21$ & $1,48 \pm 0,33$ & $1,57 \pm 0,25$ & $1,53 \pm 0,18$ \\
$\alpha$-глобулин, \% & 2 & $12,32 \pm 0,84$ & $8,44 \pm 1,09$ & $7,32 \pm 1,10$ & $9,27 \pm 1,49$ \\
& 4 & $13,41 \pm 1,11$ & $11,78 \pm 0,65$ & $7,44 \pm 1,08$ & $12,51 \pm 4,34$ \\
$\beta$ - глобулин. \% & 2 & $17,17 \pm 0,64$ & $16,84 \pm 1,09$ & $18,56 \pm 1,10$ & $17,32 \pm 0,28$ \\
& 4 & $14,83 \pm 1,17$ & $13,75 \pm 1,31$ & $16,29 \pm 1,55$ & $14,75 \pm 1,37$ \\
$\gamma$-глобулин,\% & 2 & $6,92 \pm 1,56$ & $10,84 \pm 1,16$ & $12,33 \pm 1,19$ & $11,27 \pm 1,64$ \\
& 4 & $11,05 \pm 1,23$ & $13,73 \pm 0,48$ & $14,84 \pm 1,47$ & $12,17 \pm 1,58$ \\
& & & & \\
\hline
\end{tabular}


Таблица 24

Масса внутренних органов и длина кишечника подопытных щенят лисиц

\begin{tabular}{|l|c|c|c|c|}
\hline \multirow{2}{*}{ Наименование органа } & \multicolumn{4}{|c|}{ Группы } \\
\cline { 2 - 5 } Сердце, г & I к. & II o. & Ш о. & 1V o. \\
Легкие, г & $46,23 \pm 1,46$ & $47,23 \pm 1,42$ & $47,77 \pm 1,37$ \\
Печень, г & $45,12 \pm 1,32$ & $46,18 \pm 1,47$ & $48,27 \pm 1,36$ & $47,65 \pm 1,22$ \\
Желудок, г & $136,38 \pm 2,54$ & $137,52 \pm 3,28$ & $139,11 \pm 3,12$ & $137,76 \pm 4,09$ \\
Почки, г & $37,65 \pm 1,37$ & $39,49 \pm 1,18$ & $40,00 \pm 1,39$ & $38,65 \pm 1,21$ \\
Длина кишечника, см & $47,77 \pm 1,54$ & $48,42 \pm 2,34$ & $52,75 \pm 1,93^{\mathrm{xxx}}$ & $51,24 \pm 1,75$ \\
& $238,37 \pm 3,16$ & $239,51 \pm 2,25$ & $242,55 \pm 4,91^{\mathrm{x}}$ & $241,18 \pm 3,14$ \\
& & & & \\
\hline
\end{tabular}

${ }_{-}-\mathrm{P}>0,95 ;{ }^{\mathrm{xx}}-\mathrm{P}>0,99 ;{ }^{\mathrm{xxx}}-\mathrm{P}>0,999$ 
Таблица 25

Результаты бонитировки подопытных лисиц в баллах

\begin{tabular}{|c|c|c|c|c|c|c|c|c|}
\hline Группы & $\mathrm{n}$ & $\begin{array}{c}\text { Размер и } \\
\text { телосложение }\end{array}$ & $\begin{array}{c}\text { Качество } \\
\text { опушения }\end{array}$ & $\begin{array}{c}\text { Окрас } \\
\text { волосяного } \\
\text { покрова }\end{array}$ & $\mathrm{n}$ & $\begin{array}{c}\text { Размер и } \\
\text { телосложение }\end{array}$ & $\begin{array}{c}\text { Качество } \\
\text { опушения }\end{array}$ & $\begin{array}{c}\text { Окрас } \\
\text { волосяного } \\
\text { покрова }\end{array}$ \\
\hline 1 к. & 5 & $3,51 \pm 0,23$ & $4,36 \pm 0,34$ & $3,87 \pm 0,21$ & 3 & $3,49 \pm 0,34$ & $4,43 \pm 0,21$ & $3,75 \pm 0,26$ \\
П о. & 6 & $3,66 \pm 0,34$ & $4,35 \pm 0,22$ & $3,89 \pm 0,22$ & 6 & $3,61 \pm 0,12$ & $4,49 \pm 0,11$ & $3,76 \pm 0,42$ \\
Ш о. & 8 & $3,88 \pm 0,47$ & $4,31 \pm 0,14$ & $3,88 \pm 0,34$ & 7 & $3,73 \pm 0,25$ & $4,52 \pm 0,27$ & $3,81 \pm 0,24$ \\
$1 У$ о. & 7 & $3,79 \pm 0,44$ & $4,41 \pm 0,13$ & $3,90 \pm 0,25$ & 6 & $3,68 \pm 0,34$ & $4,54 \pm 0,32$ & $3,94 \pm 0,31$ \\
\hline
\end{tabular}

${ }^{\mathrm{x}}-\mathrm{P}>0,95 ;^{\mathrm{xx}}-\mathrm{P}>0,99 ; ;^{\mathrm{xxx}}-\mathrm{P}>0,999$ 
стадийности развития организма и о частичных компенсаторынх его возможностях. Этим объясняется, что щенки-гипотрофики, получавшие СX имели более высокий относительный прирост массы тела на протяжении всего периода наблюдений.

Нами были взяты пробы крови у щенят в возрасте 2-х и 4-х месяцев. Результаты исследований крови приведены в таблицах 22 и 23.

Полученные нами данные согласуются с работами ряда авторов (Н.А.Балакирев, 1989; В.А.Берестов, 1966, 1967, 1981) и что в течение опыта гематологические показатели у щенят лисиц в этом возрасте были в пределах физиологической нормы.

Таблица 22

Гематологические показатели крови щенят лисиц, n-4

\begin{tabular}{|c|c|c|c|c|c|}
\hline \multirow{2}{*}{ Показатели } & \multirow{2}{*}{$\begin{array}{l}\text { Воз- } \\
\text { раст } \\
\text { мес }\end{array}$} & \multicolumn{4}{|c|}{ Группы } \\
\hline & & $\begin{array}{c}\text { I } \\
\text { K. }\end{array}$ & $\begin{array}{l}\text { II } \\
\text { o. }\end{array}$ & $\begin{array}{l}\text { Ш } \\
\text { o. }\end{array}$ & $\begin{array}{c}1 \mathrm{~V} \\
\text { o. }\end{array}$ \\
\hline Эритроциты, & 2 & $7.11 \pm 0.26$ & $7.39 \pm 0.25$ & $7.19 \pm 0.19$ & $7.26 \pm 0.24$ \\
\hline Млн./Мм ${ }^{3}$ & 4 & $8.91 \pm 0.18$ & $9.13 \pm 0.38$ & $9.27 \pm 0.31$ & $9.09 \pm 0.21$ \\
\hline Лейкоци & 2 & $6.34 \pm 0.39$ & $6.85 \pm 0.58$ & $7.21 \pm 0.48$ & $6,59 \pm 0.76$ \\
\hline ты, тыс & 4 & $6.12 \pm 0.58$ & $6.38 \pm 0.27$ & $6.36 \pm 0.24$ & $6.18 \pm 0.57$ \\
\hline$/ \mathrm{MM}^{3}$ & 2 & $8.64 \pm 4.08$ & $9.04 \pm 2.07$ & $9.51 \pm 1.21$ & $9.77 \pm 3.04$ \\
\hline $\begin{array}{l}\text { Гемоглобин, } \\
\text { г\100мл }\end{array}$ & 4 & $11.31 \pm 3.19$ & $14.11 \pm 3.76$ & $14.38 \pm 3.37$ & $14.17 \pm 3.47$ \\
\hline
\end{tabular}

${ }^{\mathrm{x}}-\mathrm{P}>0,95 ;^{\mathrm{xx}}-\mathrm{P}>0,99 ;{ }^{\mathrm{xxx}}-\mathrm{P}>0,999$

Введение в рацион щенят лисиц СX способствовало усилению гемоэритропоэтических функций крови. Число эритроцитов уже в 2 месячном возрасте в опытных группах было больше, чем в контрольной 
группах на $0,08-0,28$ млн./мм³. К концу эксперимента разница уже составила 0,18-0,36 млн/мм³ (2,02-4,04\%). Концентрация гемоглобина в крови щенков опытных групп на 4,62-13,07 \% превышала таковой показатель у аналогов контрольной группы в 2 месячном возрасте, а в 4 месячном возрасте превышение составило 24,75-27,14 \%. Выявленное повышение общего количества эритроцитов и гемоглобина в крови молодняка лисиц опытных групп позволяет полагать, что введение СX в рационы положительно влияет на кроветворную функцию организма.

Как известно из работ ряда авторов (С.С.Семенов, 1990; Е.В.Эйдригевич, 1978,1969) большое количество эритроцитов и гемоглобина в крови является показателем высокого уровня обмена веществ.

По содержанию в крови лейкоцитов щенята опытных групп уже в 2месячном возрасте превосходили щенят контрольной группы на 3,9413,72\%. В 4-месячном возрасте количество лейкоцитов в крови щенят опытных и контрольной групп несколько уменьшилось, но было в пределах физиологических норм. Следует также отметить, что количество лейкоцитов у щенят опытных групп было больше, чем - контрольной группы на 0,98$4,24 \%$.

Из данных, приведенных в таблице 18 и 22, видно, что молодняк контрольной группы характеризовался не только самыми низкими показателями живой массы, но и самым низким гематологическим статусом.

Как и в опыте с ПАБК все показатели крови щенят в подопытных группах находились в пределах физиологических норм.

Белковый состав крови зверей, получавших сукцинат хитозана, также свидетельствует об улучшении общего физиологического состояния их организма (таблица 23). Биохимический анализ крови показал, что содержание общего белка и соотношение белковых фракций в сыворотке 
крови тоже изменялись по мере роста подопытных щенят. Действие сукцината хитозана на белковый состав крови вызвало повышение количества общего белка и тенденцию уменьшения концентрации альбуминов.

В сыворотке крови животных опытных групп уровень общего белка был выше на 2,72-5,06\% в 2 месячном возрасте, и на 3,74-7,49\% в 4 месячном возрасте. Увеличение его тоже шло за счет глобулиновых фракций. Абсолютное содержание альбуминов в опытных группах было меньше, чем в контрольной. В соответствии с этим и белковый коэффициент в опытных группах был меньше. В возрасте 2 месяцев данный коэффициент был равен 1,59-1,71, тогда как в контрольной группе -1,68.

В 4-месячном возрасте количество альбуминов продолжило снижаться: белковый коэффициент $\quad$ в опытных группах равнялся $1,48-1,57$ (в контрольной группе -1,57).

В нашем опыте с сукцинатом хитозана увеличение концентрации глобулинов у опытных групп щенят происходило за счет гаммаглобулиновой фракции и составило в 2-месячном возрасте 10,84-12,33\%, в контрольной группах - 6,92\% , в 4-месячном возрасте - 12,17-14,84\% в опыте, 11,05\% в контроле.

Сравнение результатов биохимических и морфологических исследований крови показало, что содержание форменных элементов крови, общего белка, $\gamma$-глобулина в опытных группах было больше, чем в контрольной.

Показатели морфологического и биохимического состава крови подопытных щенят не выходили за пределы клинических норм для молодняка лисиц данного возраста. Щенки лисиц опытных групп отличались хорошим состоянием здоровья, и не имели каких-либо патологических изменений картины крови. 
С целью изучения влияния $\mathrm{CX}$ на развитие внутренних органов лисиц нами, после убоя зверей, извлекались их сердце, легкие, печень, почки, желудок и кишечник. Рост этих органов определяли путем взвешивания и измерения. Результаты проведенных исследований приведены в таблице 24.

В наших исследованиях опытные группы по массе сердца были выше контрольной на 2,16-7,61\%. По массе легких щенят опытных групп это превышение составило контроль на 2,34-6,98\%.

По массе почек щенят опытных групп превышали контрольную группу на 1,36-10,42\%. Выше была и масса желудка у щенят опытных групп на 2,65-6,24\% по сравнению с контролем.

По массе печень щенков опытных групп была больше чем у щенков контрольной группы на 0,83-2,00\%.

Полученные результаты позволяют заключить, что внутренние органы зверей опытных групп, по сравнению с отстающими в росте щенятами контрольной группы, были развиты лучше (таблица 24).

Были определены длины кишечника у щенят опытных и контрольных групп. Было отмечено, что по сравнению с контрольной группой, состоящей из отстающих в росте щенят, длина кишечника у особей опытных групп была больше на 1,14-4,18 см или на 0,47-1,75\%.

Полученные нами результаты исследований показали, что подопытные животные при добавлении сукцината хитозана в рацион имели различия по развитию внутренних органов.

Из анализа массы внутренних органов щенков лисиц (таблица 24) видно, что щенки-гипотрофики, не получавшие сукцинат хитозана, имели и достоверно наименьшую массу сердца, легких, печени, селезенки, почек и желудка. Использование сукцината хитозана повлияло и на развитие органов кровообращения, дыхательной и выделительной систем.

Следует отметить, что масса внутренних органов щенков в этом опыте 
тоже находилась в прямопропорциональной зависимости с массой тела.

Щенки опытных групп, имея большую массу органов пищеварения и их линейные размеры, лучше использовали корма рациона, давали большие среднесуточные приросты живой массы по сравнению с отстающими в росте аналогами.

Вскрытие тушек не обнаружило патологических изменений внутренних органов у щенят опытных групп. Печень, почки и селезенка по величине, цвету и консистенции были в пределах нормы.

Как показали гистологические исследования печени, почек и селезенки не имели патологических изменений.

Гистологические исследования также показали, что в печени щенят опытных и контрольной групп наблюдается жиро-белковая дистрофия гипотоцитов, сосуды триад печени (желчный проток, вена, артерия) были без каких-либо изменений.

В почках у щенят опытных и контрольной групп различий в строении не выявлено.

В лимфатических фолликулах селезенки у щенят опытных групп наблюдалась различная концентрация клеточных центров размножения: в контрольной наблюдается обеднение лимфатических фолликулов с невыраженными реактивными центрами, в опытных группах - лимфоидные фолликулы с хорошо выраженными центрами размножения.

Следовательно можно предположить, что скармливание СХ вызвало у зверей опытных групп некоторое увеличение сердца, легких, печени, почек, желудка, а также длины тонкого отдела кишечника и незначительное сокращение длины его толстого отдела. Гистологическими исследованиями не выявлено патологических изменений во внутренних органах щенят опытных групп. Было отмечено также улучшение состояния гуморального иммунитета у щенят опытных групп. Установлено, что добавка сукцината 
хитозана в корм молодняка лисиц не вызывала каких-либо отрицательных изменений в их внутренних органах.

Для оценки продуктивных и племенных качеств контрольных и опытных групп исследуемых щенят проводили бонитировку по бонитировочному ключу (требованию), в соответствии с "Инструкцией по бонитировке пушных зверей" (1986, В.А.Берестов, 1985). При этом особое внимание обращали на густоту, упругость и уравненность волосяного покрова. Обязательно учитывали и зонарность окраски пуха.

Бонитировали всех щенят опытных и контрольной групп. Результаты бонитировки показали, что вследствие повышенной живой массы к моменту бонитировки щенята опытных групп получили за размер и телосложение балл значительно выше, чем звери контрольной группы, не получавшие сукцинат хитозана (таблица 25).

У щенят опытных групп, по сравнению с контрольной группой, средний балл за этот показатель был больше у самок на 4,27-10,54\%; у самцов на $3,43-6,87 \%$.

За качество опушения оценка была выше у самцов на 1,35-2,48\%, за окраску волосяного покрова щенята опытных групп также получили выше балл на 0,25-5,06\%, но разница была недостоверна.

В результате оценки размера и телосложения, качества опушения и окраски классность щенят опытных групп была выше, чем контрольной группы.

Результаты бонитировки также свидетельствуют, что введение в рацион сукцината хитозана отстающим в росте щенятам лисиц положительно отразилось на их продуктивных показателях.

Анализ результатов сортировки шкурок зверей опытных и контрольной групп в соответствии с требованиями ГОСТа 7907-78 по размеру, цвету, группах серебристости, сорту и группам дефектов показал, что длина и пло- 
щадь шкурок у зверей опытных групп была несколько выше, чем у зверей контрольной группы (таблица 26). Длина шкурки самок опытных групп была больше на 2,27-4,58cм или на 2,83-5,71\% (P>0,95), самцов - на 1,352,69 см или на $1,61-3,22 \%$ (P>0,99). Площадь шкурки была больше соответственно на $50,47-112,61 \mathrm{~cm}^{2}$ у самок $(\mathrm{P}>0,99)$ и на $36,17-64,30 \mathrm{~cm}^{2}$ у самцов $(\mathrm{P}>0,99)$.

По степени дефектности волосяного покрова шкурки зверей опытных групп были несколько лучше, чем шкурки зверей контрольной группы.

Таблица 26

Размер шкурок молодняка лисиц, $\mathrm{n}=4$

\begin{tabular}{|c|c|c|c|}
\hline Группы & Пол & Длина шкурок, см & Площадь шкурок, см² \\
\hline \multirow[t]{2}{*}{ I к. } & q & $80,18 \pm 1,25$ & $2003,76 \pm 24,53$ \\
\hline & $\sigma^{\lambda}$ & $83,46 \pm 1,32$ & $2079,58 \pm 23,76$ \\
\hline \multirow[t]{2}{*}{ II o. } & q & $82,45 \pm 1,28$ & $2054,23 \pm 20,84$ \\
\hline & $\widehat{0}$ & $84,81 \pm 0,79$ & $2115,75 \pm 19,73$ \\
\hline \multirow[t]{2}{*}{ Ш о. } & q & $84,76 \pm 1,28$ & $2116,37 \pm 17,45$ \\
\hline & $0^{\lambda}$ & $86,15 \pm 0,56$ & $2143,88 \pm 19,81$ \\
\hline \multirow[t]{2}{*}{$1 \mathrm{~V} \mathrm{o.}$} & q & $83,47 \pm 0,76$ & $2078,62 \pm 21,14$ \\
\hline & $0^{\lambda}$ & $85,31 \pm 0,53$ & $2127,75 \pm 25,11$ \\
\hline
\end{tabular}

Состояние качества шкурок зверей по дефектности представлено в таблице 27. Нормальных шкурок и с малым дефектом среди зверей опытных групп было 75,00-87,50\%, что больше, чем в контрольной группе. 
Таблица 27

Качественные показатели шкурок лисиц контрольных и опытных групп

\begin{tabular}{|c|c|c|c|c|c|c|}
\hline \multirow{2}{*}{ Группы } & \multicolumn{5}{|c|}{ Количество и удельная масса шкурок } \\
\cline { 2 - 7 } & нормальных & \multicolumn{3}{|c|}{ Малый дефект } & Средний дефект \\
\cline { 2 - 7 } & & $\%$ & шт. & $\%$ & шт. & $\%$ \\
\hline I & 3 & 37,5 & 3 & 37,5 & 2 & 25,0 \\
II & 3 & 37,5 & 4 & 50,0 & 1 & 12,5 \\
Ш & 4 & 50,0 & 3 & 37,5 & 1 & 12,5 \\
IV & 4 & 50,0 & 2 & 25,0 & 2 & 25,0 \\
\hline
\end{tabular}

Товароведческая оценка шкурок показала, что основными дефектами в опытных и контрольной группе, как и в опыте с сукцинатом хитозана, были недостаточная густота и редкий волос на боках, свалянный или битый волос на огузках, сеченность, малые размеры, плохая обезжировка волоса.

Данные, характеризующие общие показатели качества (зачет на голову) и цены шкурок лисиц опытных и контрольной групп, представлены в таблице 28. Зачет по качеству шкурок контрольной группы составил 63,34\%, тогда как в опытных группах на 0,31-0,85\% больше.

Таблица 28

Зачет по качеству и цена шкурок контрольных и опытных групп лисиц

\begin{tabular}{|l|c|c|}
\hline \multirow{2}{*}{ Группа } & \multicolumn{2}{|c|}{ В среднем по группах } \\
\cline { 2 - 3 } & Зачет по качеству,\% & Ср. цена, руб \\
\hline 1 контрольная & 63,34 & 1583,50 \\
П опытная & 63,65 & 1591,25 \\
Ш опытная & 64,19 & 1604,75 \\
1У опытная & 63,87 & 1596,75 \\
& & \\
\hline
\end{tabular}


Соответственно была выше и цена шкурок опытных групп. Средняя реализационная цена в опытных группах была выше, чем в контрольной группах на 7,75-21,25 руб. В контрольных группах шкурки были оценены на 1583,50руб., а шкурки опытных групп зверей, получавших сукцинат хитозана были оценены на 1591,25-1604,75 руб.

Значительно больший экономический эффект был получен при введении им в корм 1,0 мг сукцината хитозана на 1 кг живой массы с 40 дня жизни, на каждой шкурке получено дополнительной прибыли 21,25 руб.

\subsection{3. Влияние янтарной кислоты на рост и развитие}

\section{гипотрофичного молодняка лисиц}

В этом опыте нами исследованы изменения живой массы, длины тела и обхвата груди в раннем онтогенезе лисиц от воздействия на них экологически безопасного препарата - янтарной кислоты.

Анализ результатов исследования свидетельствует о том, что янтарная кислота также положительно повлияла на живую массу, длину тела и обхват груди подопытных щенят-гипотрофиков (таблица 29). В опыте самки опытных групп превосходили по живой массе самок контрольной группы в 4- месячном возрасте на 0,24-0,48 кг или на 7,16-14,32 \% (P > 0,999), самцы на 0,18-0,41кг или на 5,18-11,81 \% $\quad(\mathrm{P}>0,999)$.

И в этом опыте линейные промеры тоже находились в прямо пропорциональной зависимости от живой массы щенят.

По длине тела и обхвату груди в 4-месячном возрасте щенята опытных групп превосходили контрольную группу. В опыте самки были длиннее на $4,18-7,11$ см или на 8,60-14,64\% $\quad(\mathrm{P}>0,999)$, самцы - на 2,023,85 см или на $3,85-7,34 \%(\mathrm{P}>0,999)$.

Самки опытных групп превосходили по обхвату груди самок контрольной группы на 0,57-2,97см или на $1,79-9,34 \%(\mathrm{P}>0,999)$, а самцы 
соответственно на $-1,8-2,37$ см и $5,25-6,91 \%(\mathrm{P}>0,99)$.

Среднесуточные приросты массы самок в опытных группах (таблица 30) были выше, чем в контрольной группе на 2,7-5,2 г или на 9,27-17,86\%, самцов на 2,0-4,7г или на 6,6-15,5\% больше, чем в контрольной группе. Прирост живой массы у опытных щенят больше, чем в контрольной группе у самок на 40-59\%, у самцов на 25-63\%.

Показатели индекса телосложения возрастали из месяца в месяц и максимально увеличивались к 4-месячному возрасту. Весовой индекс возрастал ежемесячно в соответствии с ростом живой массы он был больше у самцов опытных групп на 0,09-0,28\% (у самок $\mathrm{P}>0,95$ ).

Таблица 30

Абсолютный среднесуточный и относительный приросты живой массы лисиц в подопытных

\begin{tabular}{|c|c|c|c|c|c|}
\hline \multirow[t]{2}{*}{ Показатели } & \multirow[b]{2}{*}{ Пол } & \multicolumn{4}{|c|}{ Группы } \\
\hline & & $\begin{array}{l}1 \\
\text { к. }\end{array}$ & $\begin{array}{l}\Pi \Pi \\
\text { o. }\end{array}$ & $\begin{array}{c}\amalg \\
\text { o. }\end{array}$ & $\begin{array}{l}1 \mathrm{Y} \\
\mathrm{o} .\end{array}$ \\
\hline Абсолютный & q & 29,1 & 31,8 & 32,4 & 34,3 \\
\hline $\begin{array}{l}\text { среднесуточный } \\
\text { прирост, г }\end{array}$ & $0^{\lambda}$ & 30,3 & 32,3 & 33,6 & 35,0 \\
\hline Относительный & q & 358 & 398 & 400 & 417 \\
\hline $\begin{array}{l}\text { прирост живой } \\
\text { массы, \% }\end{array}$ & $\sigma^{\lambda}$ & 368 & 393 & 415 & 431 \\
\hline
\end{tabular}

Анализируя, представленные в таблице 31 показатели индексов телосложения у щенков лисиц, следует отметить, что стимулирующее влияние янтарной кислоты больше отразилось на весовом индексе у самцов.

Данные по отходу и сохранности щенят в группах представлены в таб- 
лице 32. Сохранность щенят в опытных группах была выше, чем в контрольной группе. Так, отход щенков до регистрации в Ш и 1 У опытных группах был на 5,0\% меньше, чем в контрольной группе, где были сосредоточены отстающие в росте щенята, не получавшие янтарную кислоту. Отход щенят опытных групп к 4-месячному возрасту был меньшим по сравнению с контрольной группой на 10-20\%. Сохранность к концу опыта составила в Ш и $1 У$ опытных группах $65-75 \%$, что больше чем в контроле, где сохранность составила 50,00\%.

Таблица 32

Влияние янтарной кислоты на сохранность подопытных щенят лисиц

\begin{tabular}{|c|c|c|c|c|c|c|c|}
\hline \multirow[t]{2}{*}{ Группы } & \multirow[t]{2}{*}{$\mathrm{n}$} & \multicolumn{2}{|c|}{$\begin{array}{l}\text { Отход щенят } \\
\text { на день } \\
\text { регистрации }\end{array}$} & \multicolumn{2}{|c|}{$\begin{array}{l}\text { Отход щенят } \\
\text { после } \\
\text { регистрации }\end{array}$} & \multirow[t]{2}{*}{$\begin{array}{c}\text { Кол-во } \\
\text { щенят, } \\
\text { голов }\end{array}$} & \multirow[t]{2}{*}{$\begin{array}{l}\text { Сохран- } \\
\text { ность, \% }\end{array}$} \\
\hline & & $n$ & $\%$ & $\mathrm{n}$ & $\%$ & & \\
\hline 1 к. & 20 & 5 & 25 & 5 & 25 & 10 & 50 \\
\hline По. & 20 & 8 & 40 & 3 & 15 & 9 & 45 \\
\hline Ш о. & 20 & 4 & 20 & 3 & 15 & 13 & 65 \\
\hline $1 \mathrm{Y} o$. & 20 & 4 & 20 & 1 & 5 & 15 & 75 \\
\hline
\end{tabular}

В целом подопытные щенки в этом опыте тоже отличались хорошим состоянием здоровья, без каких-либо патологических изменений. Повышение жизнеспособности и увеличение скорости роста щенковгипотрофиков опытных групп хорошо согласуются с укреплением их физиологического статуса, о чем здесь тоже свидетельствует достоверное увеличение показателей красной крови.

Меньший отход и более высокая сохранность щенят в опытных группах по сравнению с контрольной группой обусловлены положительным 
влиянием янтарной кислоты на организм этих животных. Об улучшении резистентности животных, получавших янтарную кислоту свидетельствует и повышение их сохранности.

Кровь у подопытных щенят брали в возрасте 2-х и 4-х месяцев. Результаты исследований крови приведены в таблицах 33 и 34.

Из таблиц 33 и 34 видно, что полученные нами данные свидетельствуют о том, что в течение опыта гематологические показатели у щенят лисиц в этом возрасте отклонений от физиологической нормы не имели.

Таблица 33

Гематологические показатели крови щенят лисиц, n-4

\begin{tabular}{|c|c|c|c|c|c|}
\hline \multirow[t]{3}{*}{ Показатели } & \multirow{3}{*}{$\begin{array}{l}\text { Воз- } \\
\text { раст, } \\
\text { мес }\end{array}$} & \multicolumn{4}{|c|}{ Группы } \\
\hline & & & II & Ш & $1 \mathrm{~V}$ \\
\hline & & К. & o. & o. & o. \\
\hline Эритроциты, & 2 & $7,12 \pm 0,38$ & $7,56 \pm 0,32$ & $7,39 \pm 0,41$ & $7,57 \pm 0,29$ \\
\hline млн./мм ${ }^{3}$ & 4 & $8,72 \pm 0,47$ & $9,36 \pm 0,46$ & $9,12 \pm 0,33$ & $9,38 \pm 0,42$ \\
\hline Лейкоциты, & 2 & $6,95 \pm 0,52$ & $6,74 \pm 0,51$ & $7,28 \pm 0,52$ & $7,21 \pm 0,75$ \\
\hline тыс / Mм $^{3}$ & 4 & $6,16 \pm 0,69$ & $6,36 \pm 0,36$ & $6,37 \pm 0,38$ & $6,45 \pm 0,63$ \\
\hline Гемоглобин, & 2 & $8,64 \pm 3,86$ & $9,39 \pm 2,04$ & $9,23 \pm 2,11$ & $9,75 \pm 3,11$ \\
\hline г\100мл & 4 & $11,76 \underline{2} 2,67$ & $14,41 \pm 3,63$ & $14,17 \pm 2,95$ & $14,09 \pm 3,54$ \\
\hline
\end{tabular}

${ }^{\mathrm{x}}-\mathrm{P}>0,95 ;^{\mathrm{xx}}-\mathrm{P}>0,99 ;^{\mathrm{xxx}}-\mathrm{P}>0,999$

Введение в рацион гипотрофичных щенят лисиц янтарной кислоты в этом опыте тоже способствовало усилению гемоэритропоэтических функций крови. Число эритроцитов в 2 месячном возрасте в опытных группах было

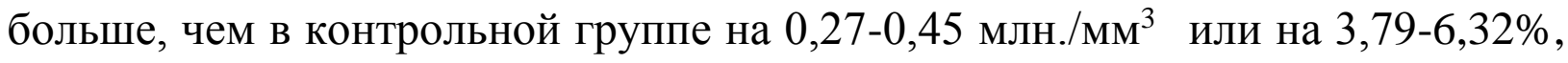
в 4-месячном возрасте на 0,4-0,66 млн./мм³ блюдалась тенденция увеличения концентрации гемоглобина в крови зверей 
опытных групп в 2 месячном возрасте на 0,59-1,11г/100мл или на 6,82$12,84 \%$, в 4 месячном возрасте на 2,33-2,65г/100мл или на 19,81-22,53\%. Выявленное повышение общего количества эритроцитов и гемоглобина в крови молодняка лисиц опытных групп дает основание полагать, что введение янтарной кислоты положительно влияет на кроветворную функцию организма. Как известно большое количество эритроцитов и гемоглобина в крови является свидетельством высокого уровня обмена веществ.

По содержанию в крови лейкоцитов щенята Ш и $1 У$ опытных групп уже в 2-месячном возрасте превосходили щенят контрольной группы на 0,26-0,33 тыс/мм ${ }^{3}$ или на $3,74-4,74 \%$. В 4-месячном возрасте количество лейкоцитов в крови щенят опытных и контрольной групп несколько уменьшилось, но было в пределах физиологических норм. Количество лейкоцитов у щенят опытных групп было больше, чем у щенят контрольной группы на 0,2-0,29 тыс/мм ${ }^{3}$ или на 3,24-4,70\%.

В рассматриваемом опыте молодняк контрольной группы характеризовался не только самыми низкими показателями живой массы, но и самым низким гематологическим статусом.

Щенята, получавшие янтарную кислоту отличались самыми высокими значениями всех перечисленных показателей красной крови. Все показатели крови находились в пределах физиологических норм.

Белковый состав крови подопытных щенят, получавших янтарную кислоту, также свидетельствует об улучшении общего физиологического состояния их организма (таблица 34). Биохимический анализ крови показал, что содержание общего белка и соотношение белковых фракций в сыворотке крови изменялись по мере роста животных. Действие янтарной кислоты на белковый состав крови проявилось в повышении количества общего белка за счет глобулиновых фракций и в тенденции уменьшения концентрации альбуминов, что может быть обусловлено с усиленным ростом щенят, 
получавших янтарную кислоту и большим расходованием альбумина для синтеза белков органов и тканей.

В сыворотке крови животных опытных групп уровень общего белка был выше на 0,47-0,55г/100мл или на 8,15-9,54\% в 4-месячном возрасте. Увеличение произошло за счет глобулиновых фракций. Абсолютное содержание альбуминов у щенят опытных групп было меньше, чем у щенят контрольной группы. Белковый коэффициент в Ш и 1 У опытных группах был меньше: в возрасте 2 месяцев данный коэффициент был равен 1,46-1,63, тогда как в контроле он равнялся 1, 69.

А в 4-месячном возрасте количество альбуминов продолжило снижаться и белковый коэффициент в опытных группах был равен 1,34-1,49 (в контроле 1,59).

Проведенные исследования морфологического и биохимического состава крови свидетельствует о том, что все показатели по группам зверей не выходили за пределы клинических норм для молодняка лисиц данного возраста. В целом подопытные щенки лисиц отличались хорошим состоянием здоровья, и были без каких-либо патологических изменений картины крови.

$\mathrm{C}$ целью изучения влияния янтарной кислоты на развитие внутренних органов лисиц нами исследованы их сердце, легкие, печень, почки, желудок и кишечник. Рост этих органов определяли путем взвешивания и измерения. Материалы проведенных исследований приведены в таблице 35.

Масса сердца щенков опытных групп больше, чем у щенков контрольной группы на 1,48-4,75г или на 3,18-10,20\%.

В наших исследованиях опытная группа превосходила контрольную по массе легких на 0,96-2,31г или на 2,02-4,86\%.

Масса почек щенков опытных групп больше массы почек щенков контрольной группы на 2,6-4,5г или на 5,43-9,41\%.

По массе печени опытные группы превосходили контрольную на 2,02- 
3,71г или на 1,50-2,75\%.

Анализ полученных результатов показал, что внутренние органы щенят опытных групп, по сравнению с отстающими в росте щенятами контрольной группы, были развиты значительно лучше (таблица 35). Опытами Ю.К. Свечина, Н.Н. Борисовой (1988), Ю.К. Свечина, Н.Н. Михеевой (1990), Spencer S., Hull D. (1984) установлено, что у подопытных щенят интенсивность роста основных тканей совпадала с интенсивностью роста всех органов. Это наблюдалось и в наших исследованиях.

Из таблицы 35 также видно увеличение длины кишечника щенков опытных групп на 1,24-2,79 см или на 0,52-1,17\%.

Как видно из полученных у подопытных щенят при добавлении янтарной кислоты в рацион имелись различия в развитии внутренних органов.

Анализ массы внутренних органов щенков лисиц (таблица 35) показал, что щенки-гипотрофики (контроль), имели и наименьшую массу сердца, легких, печени, селезенки, почек и желудка. Стимуляция роста и развития щенков с использованием янтарной кислоты повлияло и на развитие органов кровообращения, дыхательной и выделительной систем.

Следует отметить и то, что масса внутренних органов подопытных щенят и в этом случае находилась в прямопропорциональной зависимости с массой тела.

В нашем исследовании щенки опытных групп, имея большую массу органов пищеварения и их линейные размеры, лучше использовали корма рациона, давали высокие среднесуточные приросты живой массы (по сравнению с отстающими в росте аналогами).

При вскрытии тушек патологических изменений внутренних органов в опытных группах не обнаружено. Печень, почки и селезенка по величине, цвету и консистенции были в пределах нормы. 
Гистологические исследования также показали, что в печени щенят опытных и контрольной групп наблюдается жиро-белковая дистрофия гипотоцитов, сосуды триад печени (желчный проток, вена, артерия) у всех щенят были без каких-либо изменений. В почках у щенят опытных и контрольной групп различий в строении не выявлено. В лимфатических фолликулах селезенки у зверей наблюдается различная концентрация клеточных центров размножения: в контрольной группе - отмечено обеднение фолликулов, с единичными невыраженными реактивными центрами, тогда как в опытных группах - лимфоидные фолликулы с хорошо выраженными реактивными центрами.

Большое количество лимфатических фолликулов с хорошо выраженными реактивными центрами указывает на напряженный гуморальный иммунитет.

Проведенные нами морфологические и гистологические исследования свидетельствуют о том, что скармливание янтарной кислотой вызвало у зверей опытных групп некоторое увеличение сердца, легких, печени, почек, желудка, а также длины кишечника. Гистологическими исследованиями не выявлено патологических изменений во внутренних органах щенят опытных групп. Было отмечено улучшение состояния гуморального иммунитета в опытных группах.

Результаты гистологических исследований свидетельствуют о том, что добавка янтарной кислоты в корм у подопытных щенят лисиц не вызывает каких-либо отрицательных изменений во внутренних органах.

Оценку продуктивных и племенных качеств подопытных щенят контрольной и опытных групп проводили по результатам их бонитировки. Ее проводили, в соответствии с "Инструкцией по бонитировке пушных зверей" (1986, В.А.Берестов, 1985). При этом особое внимание обращали на густоту, упругость и уравненность волосяного покрова, учитывали и 
зонарность окраски пуха.

Бонитировали всех щенят опытных и контрольной групп. Результаты бонитировки представлены в таблице 36. Анализ полученных данных показывал, что щенята опытных групп получили за размер и телосложение балл значительно выше, чем щенята контрольной группы, не получавшие янтарную кислоту.

У подопытных щенят, по сравнению с щенятами контрольной группы, средний балл за этот показатель был больше у самок на 4,98-13,48 \%, у самцов на 5,30-13,27\% $(\mathrm{P}>0,95)$.

По качеству опушения и окраске волосяного покрова щенята опытных групп также получили выше балл, но разница была недостоверна.

Таблица 37

Размер шкурок молодняка лисиц, n-4

\begin{tabular}{|c|c|c|c|}
\hline Группы & Пол & Длина шкурок, см & Площадь шкурок, см² \\
\hline \multirow[t]{2}{*}{ I контр } & q & $81,37 \pm 1,65$ & $2031,74 \pm 25,89$ \\
\hline & 0 & $83,12 \pm 1,34$ & $2056,33 \pm 27,75$ \\
\hline \multirow[t]{2}{*}{ II опыт } & o & $83,47 \pm 0,65$ & $2079,57 \pm 22,17$ \\
\hline & $\hat{\sigma}$ & $84,52 \pm 0,73$ & $2111,62 \pm 21,45$ \\
\hline \multirow[t]{2}{*}{ Ш опыт } & o & $84,35 \pm 0,57$ & $2107,37 \pm 12,11$ \\
\hline & $\widehat{\jmath}$ & $85,48 \pm 0,58$ & $2135,83 \pm 16,32$ \\
\hline \multirow[t]{2}{*}{$1 \mathrm{~V}$ опыт } & q & $84,75 \pm 0,72$ & $2117,21 \pm 17,06$ \\
\hline & $\widehat{\sigma}$ & $86,09 \pm 0,38$ & $2150,76 \pm 12,62$ \\
\hline
\end{tabular}

$\mathrm{P}>0,95 ;{ }^{\mathrm{xx}}-\mathrm{P}>0,99 ;^{\mathrm{xxx}}-\mathrm{P}>0,999$

По итогам оценки размера и телосложения, качества опушения и окраски волосяного покрова был определен класс каждого зверя. В результате оценки по классности щенята опытных групп были выше, чем контрольной группы. 
Результаты бонитировки показали, что введение в рацион янтарной кислоты отстающим в росте щенятам лисиц положительно отразилось на их продуктивных показателях.

Шкурки щенят опытных и контрольной групп сортировали в соответствии с требованиями ГОСТа 7907-78. При анализе качества шкурок лисиц установлено, что в опыте среди зверей контрольной и опытных групп не было шкурок 0 и 1 размера. Результаты полученных данных представлены в таблице 37. Длина и площадь шкурок у щенят опытных групп были больше, чем у щенят контрольной группы. Длина шкурок самок была больше на 2,1-3,38см или на 2,58-4,15\%, самцов - на 1,4-2,97cм или на $1,68-3,57 \%$ (P> 0,95). Площадь шкурок также была больше у щенят опытных групп: у самок на 47,83-85,47 $\mathrm{cm}^{2}$ или на 2,35-4,20\%, у самцов на $55,29-94,43$ см$^{2}$ или на 2,68-4,59\% $(\mathrm{P}>0,95)$.

По степени дефектности волосяного покрова шкурки щенят опытных

Таблица 38

Качественные показатели шкурок лисиц контрольных и опытных групп

\begin{tabular}{|l|c|c|c|c|c|c|}
\hline \multirow{2}{*}{ Группы } & \multicolumn{5}{|c|}{ Количество и удельная масса шкурок } \\
\cline { 2 - 7 } & нормальных & \multicolumn{3}{|c|}{ Малый дефект } & \multicolumn{2}{c|}{ Средний дефект } \\
\cline { 2 - 7 } & & $\%$ & шт. & $\%$ & шт. & $\%$ \\
\hline I к. & 3 & 37,5 & 2 & 25,0 & 3 & 37,5 \\
II o. & 3 & 37,5 & 4 & 50,0 & 1 & 12,5 \\
Ш о. & 5 & 62,5 & - & - & 3 & 37,5 \\
IV o. & 4 & 50,0 & 4 & 50,0 & - & - \\
\hline
\end{tabular}

групп были лучше, чем шкурки щенят контрольной группы, состоящей из отстающих в развитии зверей. Состояние качества шкурок лисиц по дефектности представлены в таблице 38. Нормальных шкурок в Ш и 1У опытных группах было 50,00-62,50\%, тогда как в контроле было 37,50\%. 
Товароведческой оценкой шкурок установлено, что основными дефектами в опытных и контрольной группах были сеченность и разреженность волос на животе и огузке, поредение ости на боках.

Общие показатели качества (зачет на голову) и цены шкурок щенят лисиц опытных и контрольной групп, представлены в таблице 39. Зачет по качеству шкурок в контрольной группе составил $63,73 \%$, в опытных группах $64,15-65,62 \%$.

Соответственно была выше и цена шкурок опытных групп. Средняя

Таблица 39

Зачет по качеству и цена шкурок контрольных и опытных групп лисиц

\begin{tabular}{|l|c|c|}
\hline \multirow{2}{*}{ Группа } & \multicolumn{2}{|c|}{ В среднем по группе } \\
\cline { 2 - 3 } & Зачет по качеству, \% & Ср. цена, руб \\
\hline 1 к. & 63,73 & 1593,25 \\
П о. & 64,15 & 1603,75 \\
Ш о. & 65,27 & 1631,75 \\
$1 У$ о. & 65,62 & 1640,50 \\
& & \\
\hline
\end{tabular}

реализационная цена шкурок лисиц опытных групп была выше по сравнению с контрольной группой, не получавшей янтарную кислоту на 10,5-47,25 руб.и составила от 1603,75 руб. до 1640,50 рубля.

Исходя из вышеизложенного следует отметить, что введение янтарной кислоты положительно повлияло на хозяйственно-полезные признаки гипотрофичного молодняка лисиц, лучшие результаты были получены при введении в рацион янтарной кислоты в дозе 40 мг на 1 кг живой массы. 
Таблица 28

Динамика живой массы, длины тела и обхвата груди подопытного молодняка лисиц

\begin{tabular}{|c|c|c|c|c|c|c|}
\hline \multirow[t]{2}{*}{ Показатели } & \multirow{2}{*}{$\begin{array}{c}\text { Возраст, } \\
\text { мес. }\end{array}$} & \multirow[b]{2}{*}{ Пол } & \multicolumn{4}{|c|}{ Группы } \\
\hline & & & $\begin{array}{c}1 \\
\text { К. }\end{array}$ & $\begin{array}{l}\Pi \\
0 .\end{array}$ & $\begin{array}{l}\text { Ш } \\
\text { o. }\end{array}$ & $\begin{array}{l}\text { IV } \\
\text { o. }\end{array}$ \\
\hline \multirow[t]{4}{*}{ Живая масса, кг } & \multirow[t]{2}{*}{1} & 9 & $0,73 \pm 0,01$ & $0,72 \pm 0,03$ & $0,73 \pm 0,02$ & $0,74 \pm 0,01$ \\
\hline & & $\hat{0}$ & $0,74 \pm 0,02$ & $0,74 \pm 0,01$ & $0,73 \pm 0,02$ & $0,73 \pm 0,04$ \\
\hline & \multirow[t]{2}{*}{4} & q & $3,35 \pm 0,06$ & $3,59 \pm 0,06$ & $3,65 \pm 0,05$ & $3,83 \pm 0,05$ \\
\hline & & 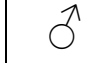 & $3,47 \pm 0,08$ & $3,65 \pm 0,04$ & $3,76 \pm 0,06$ & $3,88 \pm 0,07$ \\
\hline \multirow[t]{4}{*}{ Длина тела, см } & \multirow[t]{2}{*}{1} & q & $27,67 \pm 0,32$ & $27,56 \pm 0,31$ & $28,25 \pm 0,44$ & $27,89 \pm 0,22$ \\
\hline & & 0 & $28,53 \pm 0,26$ & $28,46 \pm 0,47$ & $27,42 \pm 0,45$ & $29,06 \pm 0,36$ \\
\hline & \multirow[t]{2}{*}{4} & q & $48,55 \pm 0,28$ & $52,73 \pm 0,46$ & $54,42 \pm 0,53$ & $55,66 \pm 0,46$ \\
\hline & & o & $52,43 \pm 0,47$ & $54,45 \pm 0,54$ & $55,34 \pm 0,41$ & $56,28 \pm 0,39$ \\
\hline \multirow[t]{4}{*}{ Обхват груди, см } & \multirow[t]{2}{*}{1} & q & $17,64 \pm 0,73$ & $17,59 \pm 0,55$ & $17,65 \pm 0,63$ & $18,22 \pm 0,21$ \\
\hline & & 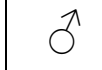 & $18,35 \pm 0,47$ & $18,19 \pm 0,41$ & $17,94 \pm 0,39$ & $17,89 \pm 0,33$ \\
\hline & \multirow[t]{2}{*}{4} & q & $31,78 \pm 0,24$ & $32,35 \pm 0,38$ & $32,78 \pm 0,41$ & $34,75 \pm 0,55$ \\
\hline & & 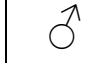 & $34,27 \pm 0,47$ & $36,07 \pm 0,29$ & $36,25 \pm 0,32$ & $36,64 \pm 0,34$ \\
\hline
\end{tabular}

${ }^{\mathrm{x}}-\mathrm{P}>0,95 ;{ }^{\mathrm{xx}}-\mathrm{P}>0,99 ;{ }^{\mathrm{xxx}}-\mathrm{P}>0,999$ 
Таблица 30

Индексы телосложения лисиц разных групп

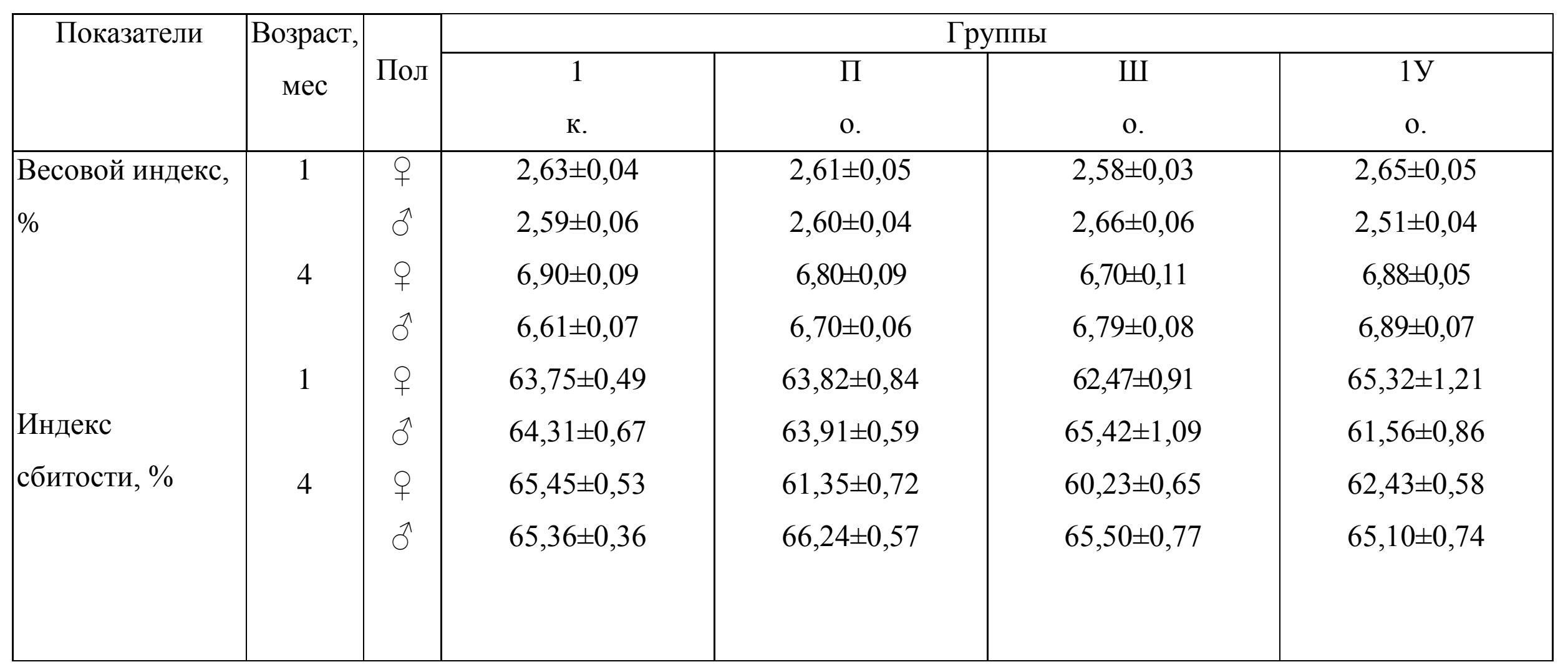

${ }^{\mathrm{x}}-\mathrm{P}>0,95 ;{ }^{\mathrm{xx}}-\mathrm{P}>0,99 ;{ }^{\mathrm{xxx}}-\mathrm{P}>0,999$ 
Содержание общего белка и фракций в сыворотке крови молодняка лисиц, n-4

\begin{tabular}{|l|c|c|c|c|c|}
\hline \multicolumn{1}{|c|}{ Показатели } & Возраст, & \multicolumn{4}{|c|}{ Группы } \\
\cline { 3 - 6 } & мес & I к. & II o. & Ш о. & $1 \mathrm{~V}$ o. \\
\hline Общий белок, & 2 & $5,32 \pm 2,79$ & $5,25 \pm 1,25$ & $5,31 \pm 1,69$ & $5,29 \pm 2,23$ \\
г/100мл & 4 & $5,76 \pm 1,54$ & $6,31 \pm 1,41$ & $6,23 \pm 0,78$ & $6,26 \pm 1,41$ \\
Альбумины, \% & 2 & $62,82 \pm 1,22$ & $63,80 \pm 1,25$ & $61,87 \pm 1,69$ & $58,78 \pm 3,38$ \\
& 4 & $61,75 \pm 2,41$ & $59,92 \pm 1,71$ & $58,81 \pm 1,33$ & $57,75 \pm 2,75$ \\
Глобулины, \% & 2 & $36,41 \pm 1,09$ & $35,81 \pm 1,14$ & $38,05 \pm 1,75$ & $39,51 \pm 3,29$ \\
& 4 & $37,46 \pm 2,24$ & $39,57 \pm 1,71$ & $40,19 \pm 1,29$ & $42,54 \pm 3,15$ \\
А/Г & 2 & $1,69 \pm 0,37$ & $1,76 \pm 0,24$ & $1,63 \pm 0,15$ & $1,46 \pm 0,32$ \\
& 4 & $1,59 \pm 0,29$ & $1,49 \pm 0,21$ & $1,43 \pm 0,37$ & $1,34 \pm 0,26$ \\
$\alpha$-глобулин, \% & 2 & $9,78 \pm 0,78$ & $8,43 \pm 1,25$ & $8,87 \pm 1,64$ & $8,38 \pm 1,56$ \\
& 4 & $10,64 \pm 1,25$ & $11,81 \pm 0,87$ & $11,68 \pm 0,64$ & $11,93 \pm 4,43$ \\
$\beta$ - глобулин. \% & 2 & $18,72 \pm 0,69$ & $16,97 \pm 1,18$ & $16,96 \pm 0,56$ & $18,75 \pm 0,54$ \\
& 4 & $15,41 \pm 1,29$ & $15,12 \pm 1,49$ & $15,76 \pm 1,32$ & $15,89 \pm 1,15$ \\
$\gamma$ - глобулин,\% & 2 & $8,78 \pm 1,74$ & $10,82 \pm 1,25$ & $12,91 \pm 1,51$ & $11,75 \pm 1,69$ \\
& 4 & $11,97 \pm 1,41$ & $12,76 \pm 0,57$ & $12,76 \pm 1,16$ & $15,14 \pm 1,48$ \\
\hline
\end{tabular}


Таблица 34

Масса внутренних органов и длина кишечника подопытных щенят лисиц

\begin{tabular}{|c|c|c|c|c|}
\hline \multirow[t]{2}{*}{ Наименование органа } & \multicolumn{4}{|c|}{ Группы } \\
\hline & I к. & II o. & Ш o. & $1 \mathrm{Vo}$ \\
\hline Сердце, г & $46,53 \pm 1,53$ & $48,01 \pm 1,48$ & $50,13 \pm 1,36$ & $51,28 \pm 1,45$ \\
\hline Легкие, г & $47,48 \pm 1,62$ & $48,44 \pm 1,35$ & $49,65 \pm 1,52$ & $49,79 \pm 1,43$ \\
\hline Печень, г & $134,43 \pm 3,45$ & $136,45 \pm 3,74$ & $138,14 \pm 3,73$ & $137,73 \pm 4,16$ \\
\hline Желудок, г & $39,28 \pm 2,26$ & $39,76 \pm 1,36$ & $40,42 \pm 1,57$ & $41,56 \pm 1,73$ \\
\hline Почки, г & $47,82 \pm 2,43$ & $50,42 \pm 1,82$ & $51,17 \pm 2,07$ & $52,32 \pm 1,22$ \\
\hline Длина кишечника, см & $238,43 \pm 2,32$ & $241,22 \pm 2,51$ & $240,73 \pm 2,48$ & $239,67 \pm 3,15$ \\
\hline
\end{tabular}

x-P>0,95;xx- P>0,99; ${ }^{x x}-P>0,999$ 
Таблица 35

Результаты бонитировки подопытных лисиц в баллах

\begin{tabular}{|c|c|c|c|c|c|c|c|c|}
\hline Группы & n & $\begin{array}{c}\text { Размер и } \\
\text { телосложение }\end{array}$ & $\begin{array}{c}\text { Качество } \\
\text { опушения }\end{array}$ & $\begin{array}{c}\text { Окрас } \\
\text { волосяного } \\
\text { покрова }\end{array}$ & $\mathrm{n}$ & $\begin{array}{c}\text { Размер и } \\
\text { телосложение }\end{array}$ & $\begin{array}{c}\text { Качество } \\
\text { опушения }\end{array}$ & $\begin{array}{c}\text { Окрас } \\
\text { волосяного } \\
\text { покрова }\end{array}$ \\
\hline 1 к. & 5 & $3,41 \pm 0,31$ & $3,81 \pm 0,34$ & $3,61 \pm 0,31$ & 5 & $3,39 \pm 0,37$ & $3,78 \pm 0,36$ & $3,84 \pm 0,42$ \\
П о. & 5 & $3,58 \pm 0,44$ & $3,86 \pm 0,33$ & $3,74 \pm 0,27$ & 4 & $3,57 \pm 0,19$ & $3,82 \pm 0,24$ & $3,77 \pm 0,15$ \\
Ш о. & 7 & $3,65 \pm 0,37$ & $3,95 \pm 0,27$ & $3,73 \pm 0,42$ & 6 & $3,63 \pm 0,32$ & $3,79 \pm 0,28$ & $3,49 \pm 0,26$ \\
$1 У$ о. & 10 & $3,87 \pm 0,43$ & $3,93 \pm 0,35$ & $3,82 \pm 0,36$ & 5 & $3,84 \pm 0,23$ & $3,92 \pm 0,25$ & $3,74 \pm 0,36$ \\
\hline
\end{tabular}

${ }^{\mathrm{x}}-\mathrm{P}>0,95 ; ;^{\mathrm{xx}}-\mathrm{P}>0,99 ; \mathrm{xxx}-\mathrm{P}>0,999$ 


\subsection{4. Влияние цеолита на рост и развитие гипотрофичного}

молодняка лисиц

Важным показателем состояния молодняка сельскохозяйственных животных, в т.ч. и молодняка клеточных пушных зверей является её живая масса. При недостаточности питательных веществ в рационах, сельскохозяйственные животные сначала снижает массу тела, а потом продуктивность. В связи с этим изыскание и добавление в корм веществ, оказывающих стимулирующее действие на процессы ассимиляции является актуальными. Согласно литературным данным, цеолит участвует в транспортировке, активации и пролонгировании ферментов и гормонов. Добавление в корм цеолитов, способствует повышению обмена веществ в организме сельскохозяйственных животных, улучшая их переваримость, что положительно сказывается на росте и развитии молодняка животных.

Исходя из этого, необходимо было изучить влияние хонгурина (цеолита месторождения Хонгуруу в Республике Саха (Якутии) на гипотрофичных щенят лисиц.

В опыте нами исследованы изменения живой массы, длины тела и обхвата груди в раннем онтогенезе лисиц от воздействия на них цеолита.

Анализ результатов исследования свидетельствует о том, что цеолит также положительно повлияла на живую массу, длину тела и обхват груди подопытных щенят-гипотрофиков (таблица 40). В опыте самки опытных групп превосходили по живой массе самок контрольной группы в 4месячном возрасте на 4,86-10,63\% (P > 0,95), самцы - на 6,25-9,52 \% $\quad(\mathrm{P}>$ $0,95)$.

И в этом опыте линейные промеры тоже находились в прямо пропорциональной зависимости от живой массы щенят.

По длине тела и обхвату груди в 4-месячном возрасте щенята опытных групп превосходили контрольную группу. В опыте самки были 
длиннее на 4,16-12,69\% (P > 0,95), самцы - на 0,4-6,58\% $(\mathrm{P}>0,95)$.

Самки опытных групп превосходили по обхвату груди самок контрольной группы на 6,19-12,24\% (P > 0,95), а самцы соответственно на $3,68-5,81 \%(\mathrm{P}>0,95)$.

Среднесуточные приросты массы самок и самцов в опытных группах (таблица 41) были выше, чем в контрольной группе на 1,9-3,8 г больше, чем в контрольной группе. Прирост живой массы у опытных щенят больше, чем в контрольной группе на 23-45\%.

Таблица 41

Абсолютный и относительный прирост живой массы лисиц в контрольной и опытных группах

\begin{tabular}{|c|c|c|c|c|c|}
\hline \multirow[t]{2}{*}{ Показатели } & \multirow{2}{*}{ Пол } & \multicolumn{4}{|c|}{ Группы } \\
\hline & & $\begin{array}{c}1 \\
\text { к. }\end{array}$ & $\begin{array}{l}\Pi \\
\text { о. }\end{array}$ & $\begin{array}{l}\text { Ш } \\
\text { o. }\end{array}$ & $\begin{array}{l}1 \mathrm{Y} \\
0 .\end{array}$ \\
\hline Абсолютный сред- & q & 28,4 & 30,3 & 32,2 & 31,0 \\
\hline $\begin{array}{l}\text { несуточный прирост, } \\
\Gamma\end{array}$ & 0 & 29,3 & 31,5 & 32,8 & 31,8 \\
\hline Относительный & q & 350 & 379 & 391 & 382 \\
\hline $\begin{array}{l}\text { прирост живой } \\
\text { массы, \% }\end{array}$ & 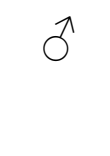 & 366 & 389 & 411 & 387 \\
\hline
\end{tabular}

Показатели индекса телосложения возрастали из месяца в месяц и максимально увеличивались к 4-месячному возрасту. Весовой индекс возрастал ежемесячно в соответствии с ростом живой массы у самок П опытной группы на 0,04\%, самцов опытных групп на 0,16-0,38\% (у самок $\mathrm{P}>0,95)$, индекс сбитости у самок на $0,08-1,32 \%$, у самцов на 2,15\% больше, чем у щенков контрольной группы, не получавших цеолит (таблица 42).

Анализируя, представленные в таблице 42 показатели индексов 
телосложения у щенков лисиц, следует отметить, что стимулирующее влияние цеолита больше отразилось на самцах опытных групп.

Сохранность поголовья является немаловажным фактором в перечне производственных показателей. Учет сохранности при проведении научнопроизводственного опыта является ещё одним из критериев оценки влияния цеолита на жизнедеятельность гипотрофичного молодняка лисиц.

В этот период молодняк особенно чувствительна к нарушениям кормления, условиям содержания, недостатку питательных и минеральных веществ.

Таблица 43

Влияние цеолита на сохранность подопытных щенят лисиц

\begin{tabular}{|c|c|c|c|c|c|c|c|}
\hline \multirow[t]{2}{*}{ Группы } & \multirow[t]{2}{*}{$\mathrm{n}$} & \multicolumn{2}{|c|}{$\begin{array}{l}\text { Отход щенят } \\
\text { на день } \\
\text { регистрации }\end{array}$} & \multicolumn{2}{|c|}{$\begin{array}{c}\text { Отход щенят } \\
\text { после } \\
\text { регистрации }\end{array}$} & \multirow[t]{2}{*}{$\begin{array}{c}\text { Кол-во } \\
\text { щенят, } \\
\text { голов }\end{array}$} & \multirow[t]{2}{*}{$\begin{array}{c}\text { Сохран- } \\
\text { ность, } \\
\%\end{array}$} \\
\hline & & $\mathrm{n}$ & $\%$ & $\mathrm{n}$ & $\%$ & & \\
\hline $1 \mathrm{~K}$. & 20 & 6 & 30 & 5 & 25 & 9 & 45 \\
\hline П о. & 20 & 6 & 30 & 4 & 20 & 10 & 50 \\
\hline Ш o. & 20 & 5 & 25 & 2 & 10 & 13 & 65 \\
\hline $1 \mathrm{Y}$ o. & 20 & 5 & 25 & 4 & 20 & 11 & 55 \\
\hline
\end{tabular}

Данные по отходу и сохранности щенят в группах представлены в таблице 43. Сохранность щенят в опытных группах была выше, чем в контрольной группе. Так, отход щенков до регистрации в Ш и 1 У опытных группах был на 5\% меньше, чем в контрольной группе, где были сосредоточены отстающие в росте щенята, не получавшие цеолит. Отход щенят опытных групп к 4-месячному возрасту был меньшим по сравнению с контрольной группой на 5-10\%. Сохранность к концу опыта составила в опытных группах 50-65\%, что больше чем в контроле, где сохранность 
составила $45 \%$.

В целом подопытные щенки в этом опыте тоже отличались хорошим состоянием здоровья, без каких-либо патологических изменений. Повышение жизнеспособности и увеличение скорости роста щенковгипотрофиков опытных групп хорошо согласуются с укреплением их физиологического статуса, о чем здесь тоже свидетельствует достоверное увеличение показателей красной крови.

Кровь у подопытных щенят брали в возрасте 2-х и 4-х месяцев. Результаты исследований крови приведены в таблицах 44 и 45.

Таблица 44

Гематологические показатели крови щенят лисиц, n-4

\begin{tabular}{|c|c|c|c|c|c|}
\hline \multirow[t]{2}{*}{ Показатели } & \multirow{2}{*}{$\begin{array}{l}\text { Возраст } \\
\text { мес }\end{array}$} & \multicolumn{4}{|c|}{ Группы } \\
\hline & & І к. & II o. & Ш о. & $1 \mathrm{Vo}$. \\
\hline Эритроциты, & 2 & $6,84 \pm 0,27$ & $7,57 \pm 0,33$ & $7,32 \pm 0,22$ & $7,34 \pm 0,19$ \\
\hline млн./мм ${ }^{3}$ & 4 & $7,78 \pm 0,17$ & $8,79 \pm 0,45$ & $9,16 \pm 0,31^{\mathrm{xx}}$ & $8,82 \pm 0,28^{x}$ \\
\hline Лейкоциты, & 2 & $6,68 \pm 0,61$ & $6,76 \pm 0,64$ & $7,32 \pm 0,49$ & $7,68 \pm 0,74$ \\
\hline тыс / мм 3 & 4 & $6,26 \pm 0,74$ & $6,64 \pm 0,29$ & $6,54 \pm 0,37$ & $6,71 \pm 0,59$ \\
\hline Гемоглобин, & 2 & $8,58 \pm 3,81$ & $8,81 \pm 2,27$ & $8,45 \pm 2,86$ & $9,64 \pm 3,04$ \\
\hline$\Gamma \backslash 100 \mathrm{Mл}$ & 4 & $12,72 \pm 3,54$ & $13,73 \pm 2,31$ & $13,84 \pm 2,78$ & $13,09 \pm 2,58$ \\
\hline
\end{tabular}

${ }^{\mathrm{x}}-\mathrm{P}>0,95 ;{ }^{\mathrm{xx}}-\mathrm{P}>0,99 ;{ }^{\mathrm{xxx}}-\mathrm{P}>0,999$

Из таблиц 44 и 45 видно, что полученные нами данные свидетельствуют о том, что в течение опыта гематологические показатели у щенят лисиц в этом возрасте отклонений от физиологической нормы не имели.

Кровь играет исключительно важную роль в биохимических процессах, протекающих в организме сельскохозяйственных животных, являясь основным индикатором, характеризующим метаболизм, выполняя 
трофическую, экскреторную, распираторную, защитную, терморегулирующую, а так же коррелятивную функции. Состав крови является одним из наиболее лабильных показателей функционального состояния организма животного, быстро и точно реагирующим на введении в корм различных добавок.

Введение в рацион щенят лисиц цеолита в этом опыте тоже способствовало усилению гемоэритропоэтических функций крови. Число эритроцитов в 4-месячном возрасте на 0,99-1,38 млн./мм ${ }^{3}$ или на 12,98$17,73 \%$ больше, чем в контрольной группе. Также наблюдалась тенденция увеличения концентрации гемоглобина в крови зверей опытных групп в 2 месячном возрасте на 0,23-1,06г/100мл или на 2,68-12,35\% во П и 1У группе, в 4 месячном возрасте на 0,37-2,01г/100мл или на 2,9-8,8\%. Выявленное повышение общего количества эритроцитов и гемоглобина в крови молодняка лисиц опытных групп дает основание полагать, что введение цеолита положительно влияет на кроветворную функцию организма. Как известно большое количество эритроцитов и гемоглобина в крови является свидетельством высокого уровня обмена веществ.

По содержанию в крови лейкоцитов щенята опытных групп уже в 2месячном возрасте превосходили щенят контрольной группы на 0,08-1,0 тыс/мм ${ }^{3}$ или на 1,19-9,58\%. В 4-месячном возрасте количество лейкоцитов в крови щенят опытной и контрольной групп несколько уменьшилось, но было в пределах физиологических норм. Количество лейкоцитов у щенят опытных групп было больше, чем у щенят контрольной группы на 0,28-0,45 тыс/мм ${ }^{3}$ или на 4,47-7,18\%.

В рассматриваемом опыте молодняк контрольной группы характеризовался не только самыми низкими показателями живой массы, но и самым низким гематологическим статусом.

Щенята, получавшие цеолит отличались самыми высокими значениями всех перечисленных показателей красной крови. Все показатели крови 
находились в пределах физиологических норм.

Белковый состав крови подопытных щенят, получавших цеолит, также свидетельствует об улучшении общего физиологического состояния их организма (таблица 45). Биохимический анализ крови показал, что содержание общего белка и соотношение белковых фракций в сыворотке крови изменялись по мере роста животных. Действие цеолита на белковый состав крови проявилось в повышении количества общего белка за счет глобулиновых фракций и в тенденции уменьшения концентрации альбуминов, что может быть обусловлено с усиленным ростом щенят, получавших цеолит и большим расходованием альбумина для синтеза белков органов и тканей.

В сыворотке крови животных опытных групп уровень общего белка был выше на 0,13-0,31г/100мл или на 2,54-6,06\% в 2-месячном возрасте; и на $0,05-0,47$ г 100 мл или на $0,86-8,15 \%$ в 4-месячном возрасте. Увеличение произошло за счет глобулиновых фракций. Абсолютное содержание альбуминов у щенят опытных групп было меньше, чем у щенят контрольной группы. Белковый коэффициент в опытных группах был меньше: в возрасте 2 месяцев данный коэффициент был равен 1,53-1,78, тогда как в контроле он равнялся 1,77 .

В 4-месячном возрасте количество альбуминов продолжило снижаться и белковый коэффициент в опытных группах был равен 1,42-1,48 (в контроле $1,54)$.

В 2-месячном возрасте $\gamma$-глобулиновой фракции в крови щенят опытных групп было на 2,74-3,8\% больше; в возрасте 4-месяцев на 2,3-3,89\%, чем в контрольной группе.

Проведенные исследования морфологического и биохимического состава крови свидетельствует о том, что все показатели по группам зверей не выходили за пределы клинических норм для молодняка лисиц данного возраста. В целом подопытные щенки лисиц отличались хорошим 
состоянием здоровья, и были без каких-либо патологических изменений картины крови.

Результаты биохимических исследований крови показывают, что скармливание цеолита оказало определенное положительное влияние на изменение изучаемых показателей, характеризующих уровень обменных процессов в организме подопытного молодняка лисиц.

С целью изучения влияния цеолита на развитие внутренних органов лисиц нами исследованы их сердце, легкие, печень, почки, желудок и кишечник. Рост этих органов определяли путем взвешивания и измерения. Материалы проведенных исследований приведены в таблице 46.

Macca сердца щенков опытных групп больше, чем у щенков контрольной группы на 0,6-2,5г или на 1,28-5,33\%.

В наших исследованиях опытные группы превосходила контрольную по массе легких на 0,21-2,58г или на 0,44-5,42\%.

Масса почек щенков опытных групп больше на 1,56-2,39г или на 3,265,00\%, чем масса почек щенков контрольной группы $(47,76 г)$.

По массе печени опытные группы превосходили контрольную на 0,471,59 г или на $0,34-1,15 \%$.

Мы полагаем, что добавление в рацион цеолита способствовало улучшению вышеуказанных процессов, a значит повышала жизнеспособность щенков-гипотрофиков.

Анализ полученных результатов показал, что внутренние органы щенят опытных групп, по сравнению с отстающими в росте щенятами контрольной группы, были развиты значительно лучше (таблица 46). Опытами Ю.К. Свечина, Н.Н. Борисовой (1988), Ю.К. Свечина, Н.Н. Михеевой (1990), Spencer S., Hull D. (1984) установлено, что у подопытных щенят интенсивность роста основных тканей совпадала с интенсивностью роста всех органов. Это наблюдалось и в наших исследованиях.

Из таблицы 46 также видно увеличение длины кишечника на 1,52 см 
или на $0,63 \%$ в Ш опытной группе, по сравнению с контролем.

Как видно из полученных у подопытных щенят при добавлении цеолита в рацион имелись различия в развитии внутренних органов.

Анализ массы внутренних органов щенков лисиц (таблица 46) показал, что щенки-гипотрофики (контроль), имели наименьшую массу сердца, легких, печени, селезенки, почек и желудка. Стимуляция роста и развития щенков с использованием цеолита повлияла и на развитие органов кровообращения, дыхательной и выделительной систем.

Следует отметить и то, что масса внутренних органов подопытных щенят и в этом случае находилась в прямопропорциональной зависимости с массой тела.

В нашем исследовании щенки опытных групп, имея большую массу органов пищеварения и их линейные размеры, лучше использовали корма рациона, давали высокие среднесуточные приросты живой массы (по сравнению с отстающими в росте аналогами).

При вскрытии тушек патологических изменений внутренних органов в опытных группах не обнаружено. Печень, почки и селезенка по величине, цвету и консистенции были в пределах нормы.

Гистологические исследования также показали, что в печени щенят опытных и контрольной групп наблюдается жиро-белковая дистрофия гипотоцитов, сосуды триад печени (желчный проток, вена, артерия) у всех щенят были без каких-либо изменений. В почках у щенят опытных и контрольной групп различий в строении не выявлено. В лимфатических фолликулах селезенки у зверей наблюдается различная концентрация клеточных центров размножения: в контрольной группе - отмечено обеднение фолликулов, с единичными невыраженными реактивными центрами, тогда как в опытных группах - лимфоидные фолликулы с умеренно выраженными реактивными центрами.

Проведенные нами морфологические и гистологические исследования 
свидетельствуют о том, что скармливание цеолита вызвало у зверей опытных групп некоторое увеличение сердца, легких, печени, почек, желудка, а также длины кишечника. Гистологическими исследованиями не выявлено патологических изменений во внутренних органах щенят опытных групп. Было отмечено улучшение состояния гуморального иммунитета в опытных группах щенят.

Результаты гистологических исследований свидетельствуют о том, что добавка цеолита в корм у подопытных щенят лисиц не вызывает каких-либо отрицательных изменений во внутренних органах.

Оценку продуктивных и племенных качеств подопытных щенят контрольной и опытной групп проводили по результатам их бонитировки. Ee проводили, в соответствии с "Инструкцией по бонитировке пушных зверей" (1986, В.А.Берестов, 1985).

Бонитировали всех щенят опытных и контрольной групп. Результаты бонитировки представлены в таблице 47. Анализ полученных данных показывал, что щенята опытных групп получили за размер и телосложение балл значительно выше, чем щенята контрольной группы, не получавшие цеолит.

У подопытных щенят, по сравнению с щенятами контрольной группы, средний балл за этот показатель был больше у самок на 3,2-5,53 \%, у самцов на 5,3-10,61\% (P>0,95).

По качеству опушения и окраске волосяного покрова щенята опытных групп также получили выше балл, но разница была недостоверна.

По итогам оценки размера и телосложения, качества опушения и окраски волосяного покрова был определен класс каждого зверя. В результате оценки по классности щенята опытных групп были выше, чем контрольной группы.

Результаты бонитировки показали, что введение в рацион цеолита отстающим в росте щенятам лисиц положительно отразилось на их 
продуктивных показателях.

Шкурки щенят опытных и контрольной групп сортировали в соответствии с требованиями ГОСТа 7907-78. При анализе качества шкурок лисиц установлено, что в опыте среди зверей опытных и контрольной групп не было шкурок 0 и 1 размера. Результаты полученных данных представлены в таблице 48. Длина и площадь шкурок у щенят опытных

Таблица 48

Размер шкурок молодняка лисиц, n-4

\begin{tabular}{|c|c|c|c|}
\hline Группы & Пол & Длина шкурок, см & Площадь шкурок, см² \\
\hline \multirow[t]{2}{*}{ I к. } & q & $81,09 \pm 1,37$ & $2025,63 \pm 32,56$ \\
\hline & $\hat{0}$ & $83,52 \pm 1,15$ & $2086,47 \pm 27,17$ \\
\hline \multirow[t]{2}{*}{ II o. } & q & $82,67 \pm 0,79$ & $2064,72 \pm 21,28$ \\
\hline & $\hat{0}$ & $83,86 \pm 0,64$ & $2095,11 \pm 22,05$ \\
\hline \multirow[t]{2}{*}{ Ш о. } & q & $84,34 \pm 0,37$ & $2107,68 \pm 10,93$ \\
\hline & $\widehat{0}$ & $85,17 \pm 0,56$ & $2128,59 \pm 14,82$ \\
\hline \multirow[t]{2}{*}{$1 \mathrm{~V}$ o. } & q & $83,69 \pm 0,71$ & $2090,61 \pm 15,53$ \\
\hline & $\widehat{0}$ & $84,72 \pm 0,36$ & $2116,75 \pm 11,04$ \\
\hline
\end{tabular}

$\mathrm{P}>0,95 ;{ }^{\mathrm{xx}}-\mathrm{P}>0,99 ;{ }^{\mathrm{xxx}}-\mathrm{P}>0,999$

групп были выше, чем у щенят контрольной группы. Длина шкурок самок была больше на 1,58-3,25см или на 1,94-4,0\%, самцов - на 0,34-1,65см или на 0,4-1,97\% (P> 0,95). Площадь шкурок также была больше у щенят опытных групп: у самок на 39,09-82,05 $\mathrm{cm}^{2}$, у самцов на 8,63-42,12 $\mathrm{cm}^{2}(\mathrm{P}>0,95)$.

По степени дефектности волосяного покрова шкурки щенят опытных групп были несколько лучше, чем шкурки щенят контрольной группы, состоящей из отстающих в развитии зверей. Состояние качества шкурок лисиц по дефектности представлены в таблице 49. Нормальных шкурок в Ш 
и 1 У опытных группах было 50,00\%, тогда как в контроле на $12,50 \%$ меньше.

Таблица 49

Качественные показатели шкурок лисиц контрольной и опытных групп

\begin{tabular}{|l|c|c|c|c|c|c|}
\hline \multirow{2}{*}{ Группы } & \multicolumn{5}{|c|}{ Количество и удельная масса шкурок } \\
\cline { 2 - 7 } & нормальных & \multicolumn{3}{|c|}{ Малый дефект } & Средний дефект \\
\cline { 2 - 7 } & & $\%$ & шт. & $\%$ & шт. & $\%$ \\
\hline I к. & 3 & 37,5 & 3 & 37,5 & 2 & 25,0 \\
II o. & 3 & 37,5 & 2 & 25,0 & 3 & 37,5 \\
Ш о. & 4 & 50,0 & 3 & 37,5 & 1 & 12,5 \\
1V o. & 4 & 50,0 & 2 & 25,0 & 2 & 25,0 \\
\hline
\end{tabular}

Товароведческой оценкой шкурок установлено, что основными дефектами в опытной и контрольной группах были сеченность и разреженность волос на животе и огузке, поредение ости на боках.

Таблица 50

Зачет по качеству и цена шкурок подопытных групп лисиц

\begin{tabular}{|l|c|c|}
\hline \multirow{2}{*}{ Группа } & \multicolumn{2}{|c|}{ В среднем по группе } \\
\cline { 2 - 3 } & Зачет по качеству,\% & Ср. цена, руб \\
\hline 1 к. & 63,71 & 1592,75 \\
П о. & 63,58 & 1589,50 \\
Ш о. & 64,62 & 1615,50 \\
1 У о. & 64,37 & 1609,25 \\
& & \\
\hline
\end{tabular}

Данные, характеризующие общие показатели качества (зачет на головку) и цены шкурок лисиц опытных и контрольной групп, представлены в таблице 50. Зачет по качеству шкурок в Ш и 1У опытных группах - 64,37- 
$64,62 \%$, что больше чем в контроле $-63,71 \%$. Это отразилось на стоимости шкурковой продукции, она была больше в Ш и 1 У опытных группах на 16,522,75руб. по сравнению с контролем и составила 1609,25-1615,59 руб, тогда как в контрольной группе, где содержались гипотрофичные щенки, не получавшие цеолит средняя цена составила 1592,75 рубля.

Исходя из вышеизложенного следует отметить, что введение цеолита в рацион лисиц положительно повлияло на хозяйственно-полезные признаки гипотрофичного молодняка. Лучшие результаты были получены при введении цеолита в дозе $5 \Gamma$ на 1 голову. 
Таблица 40

Динамика живой массы, длины тела и обхвата груди подопытного молодняка лисиц

\begin{tabular}{|c|c|c|c|c|c|c|}
\hline \multirow[t]{2}{*}{ Показатели } & \multirow{2}{*}{$\begin{array}{c}\text { Возраст, } \\
\text { мес. }\end{array}$} & \multirow[b]{2}{*}{ Пол } & \multicolumn{4}{|c|}{ Группы } \\
\hline & & & $\begin{array}{l}1 \\
\kappa .\end{array}$ & $\begin{array}{l}\Pi \\
\text { о. }\end{array}$ & $\begin{array}{l}\text { Ш } \\
\text { o. }\end{array}$ & $\begin{array}{l}\text { IV } \\
\text { o. }\end{array}$ \\
\hline \multirow[t]{4}{*}{ Живая масса, кг } & \multirow[t]{2}{*}{1} & q & $0,73 \pm 0,03$ & $0,72 \pm 0,03$ & $0,74 \pm 0,01$ & $0,73 \pm 0,02$ \\
\hline & & $0^{\lambda}$ & $0,72 \pm 0,02$ & $0,73 \pm 0,01$ & $0,72 \pm 0,02$ & $0,74 \pm 0,02$ \\
\hline & \multirow[t]{2}{*}{4} & q & $3,29 \pm 0,07$ & $3,45 \pm 0,08$ & $3,64 \pm 0,06^{\mathrm{xxx}}$ & $3,52 \pm 0,07^{x}$ \\
\hline & & $\widehat{0}$ & $3,36 \pm 0,08$ & $3,57 \pm 0,06^{x}$ & $3,68 \pm 0,08^{\mathrm{xx}}$ & $3,61 \pm 0,08^{\mathrm{xx}}$ \\
\hline \multirow[t]{4}{*}{ Длина тела, см } & \multirow[t]{2}{*}{1} & q & $27,85 \pm 0,24$ & $28,07 \pm 0,44$ & $27,93 \pm 0,35$ & $27,86 \pm 0,16$ \\
\hline & & $0^{\lambda}$ & $28,42 \pm 0,20$ & $28,33 \pm 0,46$ & $28,49 \pm 0,49$ & $28,37 \pm 0,41$ \\
\hline & \multirow[t]{2}{*}{4} & q & $46,79 \pm 0,42$ & $48,74 \pm 0,38^{\mathrm{xx}}$ & $52,45 \pm 0,53^{\mathrm{xxx}}$ & $51,63 \pm 0,41^{\mathrm{xxx}}$ \\
\hline & & $\widehat{0}$ & $51,15 \pm 0,51$ & $51,37 \pm 0,42$ & $54,52 \pm 0,44^{\mathrm{xxx}}$ & $53,71 \pm 0,36^{\mathrm{xxx}}$ \\
\hline \multirow[t]{4}{*}{ Обхват груди, см } & \multirow[t]{2}{*}{1} & q & $17,81 \pm 0,73$ & $18,13 \pm 0,36$ & $17,86 \pm 0,69$ & $17,61 \pm 0,66$ \\
\hline & & $0^{\lambda}$ & $18,22 \pm 0,22$ & $18,44 \pm 0,25$ & $18,37 \pm 0,51$ & $18,28 \pm 0,25$ \\
\hline & \multirow[t]{2}{*}{4} & q & $31,78 \pm 0,54$ & $33,75 \pm 0,35^{\mathrm{xx}}$ & $35,67 \pm 0,41^{\mathrm{xxx}}$ & $35,17 \pm 0,61^{\mathrm{xxx}}$ \\
\hline & & $0^{\pi}$ & $33,89 \pm 0,32$ & $35,14 \pm 0,48^{x}$ & $35,86 \pm 0,29 \times x x$ & $35,39 \pm 0,48^{x}$ \\
\hline
\end{tabular}

${ }^{\mathrm{x}}-\mathrm{P}>0,95 ;^{\mathrm{xx}}-\mathrm{P}>0,99 ;^{\mathrm{xxx}}-\mathrm{P}>0,999$ 
Таблица 42

Индексы телосложения лисиц разных групп

\begin{tabular}{|c|c|c|c|c|c|c|}
\hline \multirow[t]{3}{*}{ Показатели } & \multirow{3}{*}{$\begin{array}{c}\text { Возраст, } \\
\text { мес }\end{array}$} & \multirow{3}{*}{ Пол } & \multicolumn{4}{|c|}{ Группы } \\
\hline & & & 1 & $\Pi$ & Ш & $1 \mathrm{y}$ \\
\hline & & & к. & o. & o. & o. \\
\hline Весовой индекс, & 1 & $\bar{q}$ & $2,62 \pm 0,08$ & $2,56 \pm 0,09$ & $2,64 \pm 0,07$ & $2,62 \pm 0,07$ \\
\hline$\%$ & & o & $2,53 \pm 0,07$ & $2,57 \pm 0,07$ & $2,52 \pm 0,09$ & $2,60 \pm 0,06$ \\
\hline & 4 & q & $7,03 \pm 0,07$ & $7,07 \pm 0,08$ & $6,93 \pm 0,11$ & $6,81 \pm 0,12$ \\
\hline & & 0 & $6,56 \pm 0,09$ & $6,94 \pm 0,12^{x}$ & $6,74 \pm 0,09$ & $6,72 \pm 0,09$ \\
\hline Индекс & 1 & q & $63,94 \pm 0,48$ & $64,58 \pm 0,94$ & $63,94 \pm 0,87$ & $63,20 \pm 0,68$ \\
\hline сбитости, \% & & o & $64,10 \pm 0,53$ & $65,09 \pm 1,42$ & $64,47 \pm 0,92$ & $64,43 \pm 0,72$ \\
\hline & 4 & o & $67,92 \pm 0,61$ & $69,24 \pm 0,60$ & $68,00 \pm 0,39$ & $68,11 \pm 0,64$ \\
\hline & & o & $66,25 \pm 0,47$ & $68,40 \pm 0,74^{\mathrm{x}}$ & $65,77 \pm 0,85$ & $65,89 \pm 0,89$ \\
\hline
\end{tabular}

${ }^{\mathrm{x}}-\mathrm{P}>0,95 ;{ }^{\mathrm{xx}}-\mathrm{P}>0,99 ;{ }^{\mathrm{xxx}}-\mathrm{P}>0,999$ 
Содержание общего белка и фракций в сыворотке крови молодняка лисиц, n-4

\begin{tabular}{|l|c|c|c|c|c|}
\hline \multicolumn{1}{|c|}{ Показатели } & Возраст, & \multicolumn{4}{|c|}{ Группы } \\
\cline { 3 - 6 } & мес & I к. & II o. & Ш o. & 1 o. \\
\hline Общий белок, & 2 & $5,11 \pm 2,87$ & $5,31 \pm 1,33$ & $5,42 \pm 1,75$ & $5,24 \pm 2,09$ \\
г/100мл & 4 & $5,76 \pm 1,46$ & $6,15 \pm 1,29$ & $6,23 \pm 0,88$ & $5,81 \pm 1,27$ \\
Альбумины, \% & 2 & $64,12 \pm 1,23$ & $64,20 \pm 1,11$ & $62,33 \pm 1,73$ & $60,18 \pm 3,38$ \\
& 4 & $59,85 \pm 2,41$ & $58,43 \pm 1,57$ & $59,27 \pm 1,28$ & $58,21 \pm 3,05$ \\
Глобулины, \% & 2 & $35,71 \pm 1,16$ & $35,54 \pm 1,12$ & $36,45 \pm 1,73$ & $38,63 \pm 3,39$ \\
& 4 & $38,53 \pm 2,27$ & $39,31 \pm 1,56$ & $39,73 \pm 1,29$ & $40,47 \pm 2,85$ \\
& 2 & $1,77 \pm 0,42$ & $1,78 \pm 0,33$ & $1,69 \pm 0,44$ & $1,53 \pm 0,37$ \\
А/Г & 4 & $1,54 \pm 0,14$ & $1,46 \pm 0,46$ & $1,48 \pm 0,15$ & $1,42 \pm 0,29$ \\
$\alpha$-глобулин, \% & 2 & $9,78 \pm 0,78$ & $9,23 \pm 1,22$ & $7,76 \pm 1,73$ & $9,21 \pm 1,57$ \\
& 4 & $11,65 \pm 1,17$ & $11,78 \pm 0,87$ & $10,69 \pm 0,66$ & $11,54 \pm 4,48$ \\
$\beta$ - глобулин. \% & 2 & $18,63 \pm 0,73$ & $16,74 \pm 1,31$ & $18,16 \pm 0,58$ & $19,17 \pm 0,59$ \\
& 4 & $16,58 \pm 1,29$ & $15,27 \pm 1,47$ & $15,21 \pm 0,86$ & $15,72 \pm 1,18$ \\
$\gamma$ - глобулин, \% & 2 & $7,47 \pm 1,76$ & $10,22 \pm 1,21$ & $11,27 \pm 1,51$ & $10,21 \pm 1,79$ \\
& 4 & $10,23 \pm 1,51$ & $12,53 \pm 0,71$ & $14,12 \pm 0,94$ & $13,38 \pm 1,58$ \\
& & & &
\end{tabular}


Таблица 46

Масса внутренних органов и длина кишечника подопытных щенят лисиц

\begin{tabular}{|l|c|c|c|c|}
\hline Наименование органа & \multicolumn{3}{|c|}{ Группы } \\
\cline { 2 - 5 } & I к. & II o. & Ш о. & $49,32 \pm 1,61$ \\
Легкие, г & $46,82 \pm 1,38$ & $47,42 \pm 1,71$ & \\
Печень, г & $47,54 \pm 1,47$ & $47,75 \pm 1,49$ & $50,12 \pm 1,53$ & $48,25 \pm 1,42$ \\
Желудок, г & $137,15 \pm 3,16$ & $138,16 \pm 3,81$ & $138,74 \pm 4,44$ & $137,62 \pm 4,51$ \\
Почки, г & $39,47 \pm 1,48$ & $40,53 \pm 1,27$ & $41,72 \pm 1,39$ & $39,84 \pm 1,43$ \\
Длина кишечника, см & $239,23 \pm 2,58$ & $238,86 \pm 2,42$ & $50,15 \pm 1,88$ & $50,09 \pm 1,23$ \\
\hline
\end{tabular}

x-P>0,95;xx- P>0,99; ${ }^{x x}-P>0,999$ 
Таблица 47

Результаты бонитировки подопытных лисиц в баллах

\begin{tabular}{|l|c|c|c|c|c|c|c|c|}
\hline Группы & $\mathrm{n}$ & $\begin{array}{c}\text { Размер и } \\
\text { телосложение }\end{array}$ & $\begin{array}{c}\text { Качество } \\
\text { опушения }\end{array}$ & $\begin{array}{c}\text { Окрас } \\
\text { волосяного } \\
\text { покрова }\end{array}$ & $\mathrm{n}$ & $\begin{array}{c}\text { Размер и } \\
\text { телосложение }\end{array}$ & $\begin{array}{c}\text { Качество } \\
\text { опушения }\end{array}$ & $\begin{array}{c}\text { Окрас } \\
\text { волосяного } \\
\text { покрова }\end{array}$ \\
\hline 1 к. & 6 & $3,43 \pm 0,51$ & $4,36 \pm 0,24$ & $3,53 \pm 0,18$ & 3 & $3,39 \pm 0,19$ & $4,28 \pm 0,31$ & $3,59 \pm 0,29$ \\
$П$ о. & 6 & $3,54 \pm 0,42$ & $4,29 \pm 0,31$ & $3,82 \pm 0,22$ & 4 & $3,57 \pm 0,32$ & $4,16 \pm 0,18$ & $3,65 \pm 0,41$ \\
Ш о. & 7 & $3,62 \pm 0,36$ & $4,45 \pm 0,24$ & $3,76 \pm 0,34$ & 6 & $3,75 \pm 0,27$ & $4,31 \pm 0,32$ & $3,72 \pm 0,37$ \\
$1 У$ о. & 5 & $3,59 \pm 0,29$ & $4,38 \pm 0,37$ & $3,78 \pm 0,19$ & 6 & $3,68 \pm 0,36$ & $4,35 \pm 0,24$ & $3,63 \pm 0,32$ \\
\hline
\end{tabular}

${ }^{x}-P>0,95 ;{ }^{x x}-P>0,99 ; ;^{x x x}-P>0,999$ 
3.2.5. Результаты дисперсионного анализа оптимальных доз биологически активных веществ (парааминобензойной кислоты, сукцината хитозана, янтарной кислоты и цеолита)

Для определения доли влияния различных факторов на отстающих в росте щенят лисиц нами был проведен двухфакторный дисперсионный анализ. Были изучены следующие показатели: биологически активные вещества с разными дозами, живая масса, сохранность молодняка и размер шкурок. Результаты представлены в таблице 51 и 52.

Таблица 51

Дисперсионный анализ оптимальной дозировки

\begin{tabular}{|l|c|c|c|}
\hline \multicolumn{1}{|c|}{ Препараты, дозы } & Сумма & Среднее & Дисперсия \\
\hline Цеолит & 129,04 & 43,01 & 1500,6501 \\
контроль & 140,79 & 46,93 & 1578,0447 \\
1г & 158,84 & 52,94 & 1864,8485 \\
5 Гг & 141,35 & 47,11 & 1612,7908 \\
10г & & & \\
Янтарная кислота & 125,28 & 41,76 & 1537,3956 \\
контроль & 147,19 & 49,06 & 1692,5092 \\
10мг/кг ж.м. & 153,03 & 51,01 & $1776,93.07$ \\
20мг/кг ж.м. & 164,15 & 54,71 & 1979,4795 \\
40мг/кг ж.м. & & & \\
Парааминобензойная & & & \\
кислота & 135,65 & 45,21 & 1570,7024 \\
контроль & 132,61 & 44,20 & 1615,3102 \\
0,5мг/кг ж.м. & 164,27 & 54,75 & 1970,7606 \\
1,0мг/кг ж.м. & 153,61 & 51,20 & 1791,5270 \\
1,5мг/кг ж.м. & & & \\
Сукцинат хитозана & 130,62 & 43,54 & 1561,0588 \\
контроль & 136,77 & 45,59 & 1604,6017 \\
0,5мг/кг ж.м. & 153,41 & 51,13 & 1788,0410 \\
1,0мг/кг ж.м. & 142,76 & 47,58 & 1666,9205 \\
1,5мг/кг ж.м. & & & \\
& & & \\
& & & \\
\hline
\end{tabular}

Дисперсионный анализ (таблица 51) дал оптимальную дозировку биологически активных веществ: цеолит, янтарной кислот (ЯК), 
парааминобензойной кислоты (ПАБК) и сукцината хитозана (CX). Полученные данные исследований в опытах 1, П, Ш и 1 У подтвердились еще раз результатами дисперсионного анализа.

Таблица 52

Дисперсионный анализ оптимального сочетания биологического активного вещества для гипотрофичного молодняка лисиц

\begin{tabular}{|c|c|c|c|c|}
\hline Варианты & $\mathrm{C}$ & $\mathrm{F}_{\mathrm{i}}$ & $\eta^{2}$ & $\mathrm{~F}_{\mathrm{st}}$ \\
\hline ПАБК х ЯК & 70,48 & 1,33 & 0,30 & 2,76 \\
Цеолит х СХ & 35,25 & 1,54 & 0,22 & 2,76 \\
Цеолит х ПАБК & 55,32 & 1,45 & 0,26 & 2,76 \\
Цеолит х ЯК & 62,01 & 1,49 & 0,24 & 2,76 \\
ЯК х СХ & 55,69 & 1,37 & 0,28 & 2,76 \\
ПАБК х СХ & 48,73 & 1,34 & 0,30 & 2,76 \\
& & & & \\
\hline
\end{tabular}

Дисперсионный анализ показал, что разные сочетания биологически активных веществ, для стимуляции роста и развития гипотрофичного молодняка лисиц являются недостоверными (таблица 52). Недостоверность влияния различных сочетаний биологически активных веществ означает невозможность использования препаратов в этих сочетаниях для стимуляции гипотрофичных щенков зверей.

Исходя, из полученных результатов нами для дальнейших исследований были выбраны дозировки, которые представлены в таблице 50. Оптимальной дозой для гипотрофичного молодняка серебристо-черных лисиц являются:

а) парааминобензойная кислота - 1,0 мг на 1 кг живой массы;

б) сукцинат хитозана - 1,0 мг на 1 кг живой массы;

в) янтарная кислота - 40,0 мг на 1 кг живой массы;

г) цеолит $-5,0$ г.

3.3. Определение оптимально эффективного биологически активного препарата для стимуляции роста и развития гипотрофичного молодняка лисиц

Гипотрофия молодняка - нарушение роста и развития новорожденных 
животных вследствие расстройства их питания во внутриутробном и внеутробном периодах жизни, наблюдается у молодняка всех сельскохозяйственных животных.

Анализ сложившегося положения в звероводстве свидетельствует о том, что причины неблагополучия имеют многофакторный характер. Это и не полностью сбалансировано кормление, наличие в кормах токсических элементов и нарушения обмена веществ (Квартникова Е.Г., 2002).

Под гипотрофией в настоящее время понимают длительное, хроническое заболевание, сопровождающееся нарушением трофической функции организма - пищеварения, обмена веществ, с задержкой физического и статического развития.

У гипотрофичных щенков снижены иммунобиологические защитные силы организма, в связи, с чем среди них наблюдатся высокий процент заболеваемости и смертности (Владимиров А.В., 2002).

Молодняку клеточных пушных зверей свойственен короткий период интенсивного роста. Задержка развития в это время в последующем уже не восполняется, поэтому важно максимально интенсифицировать рост молодняка с первых месяцев их жизни. В этой связи использование биологически активных веществ для физиологической стимуляции роста и развития молодняка зверей приобретает особое значение.

По литературным данным, известно, что парааминобензойная кислота через фолиевую кислоту контролирует синтез генов (нуклеиновых кислот). Участвует в контроле синтеза некоторых аминокислот (метионин). Янтарная кислота участвует в выработке энергии клетками, участвует в энергетическом обмене. Способствует выработке аденозинтрифосфорной кислоты, усиливает клеточное дыхание. Сукцинат хитозана является стимулятором естественной резистентности организма к бактериальной инфекции. Цеолит участвует в транспортировке, активации и пролонгировании ферментов и гормонов. Следовательно, вышеназванные биологически активные вещества оказывает 
положительное воздействие на физиологические процессы в организме животных, которая способствует быстрому росту и развитию гипотрофичного молодняка, повышению его жизнедеятельности.

Действие адаптогенных препаратов заключается в том, что они в отличие от антибиотиков воздействуют опосредованно на весь организм, способствуя активизации его скрытых резервных механизмов в случае возникновения неблагоприятных условий. Поэтому их назначают не постоянно, как витамины, а отработанными в каждом конкретном случае курсами (Кварникова Е.Г., 2002).

Результаты наших исследований свидетельствуют о том, что использование адаптогенов положительно отразилось на живой массе, длине тела и обхвате груди у отстающих в росте щенят лисиц (таблица 53). Лучшие результаты были получены в 1У опытной группе, где щенки получали 40,0 мг янтарной кислоты на I кг живой массы. Так по сравнению с контрольной группой, в которой лисицы не получали адаптоген в возрасте 4 месяцев разница у зверей из 1У группы составила 0,48-0,59 кг (Р>0,999). С меньшей интенсивностью с ли щенята опытных групп, получавшие парааминобензойную кислоту - 1,0 мг (П опытная группа), 1,0 мг сукцината хитозана (Ш опытная группа), 5,0г цеолита (У опытная группа). Они превосходили контрольную группу соответственно на 0,34-0,36 кг (П группа), на 0,22 кг (Ш группа), на 0,31-0,29 кг (У группа).

По длине тела и обхвату груди в 4-месячном возрасте звери опытных групп заметно превосходили контрольную группу. Разница была достоверна по длине тела у самцов всех групп, самочек 1У и У группы; по обхвату груди - у самок и самцов П и 1У групп (P>0,95).

На основании полученных результатов нами были вычислены индексы: весовой и сбитости. Весовой индекс в опыте был выше у щенков контрольных групп соответствующего показателя у зверей из контрольной группы. Результаты достоверны у самок и самцов в 4-месячном возрасте во П и 
1Угруппах (P>0,95) (таблица 55).

В опытных группах (парааминобензойная кислота, сукцинат хитозана, янтарная кислота и цеолит) такие показатели, как абсолютный среднесуточный прирост, относительный прирост, коэффициент роста были выше, чем в контрольной группе, и как следствие, достоверно выше была масса тела. Здесь надо отметить, что лучшие результаты были в опытной группе, получавшей янтарную кислоту (таблица 54).

Таблица 54

Абсолютный среднесуточный и относительный приросты живой массы лисиц контрольной и опытных групп

\begin{tabular}{|c|c|c|c|c|c|c|}
\hline \multirow[t]{3}{*}{ Показатели } & \multirow{3}{*}{ Пол } & \multicolumn{5}{|c|}{ Группы } \\
\hline & & 1 & $\Pi$ & $\begin{array}{l}\amalg \\
\end{array}$ & $1 \mathrm{y}$ & $\mathrm{y}$ \\
\hline & & к. & o. & o. & o. & o. \\
\hline Абсолютный & q & 30,8 & 34,2 & 32.8 & 36.1 & 33,8 \\
\hline среднесуточный & o & 31,0 & 34,1 & 33.0 & 37.4 & 33,6 \\
\hline прирост, г & & & & & & \\
\hline Относительный & q & 402 & 410 & 405 & 464 & 417 \\
\hline прирост живой & 0 & 392 & 411 & 396 & 468 & 398 \\
\hline массы, \% & & & & & & \\
\hline
\end{tabular}

Применение биологически активных веществ дала возможность за период выращивания улучшить показатели роста и развития щенков лисиц, родившихся слабыми и с малой живой массой. При этом улучшилась резистентность животных, о чем свидетельствуют повышение их сохранности.

Сохранность щенят в опытных группах выше, чем в контрольной 
группе. Отход щенков до регистрации во П опытной группе был на $6,44 \%$ меньше, в Ш группе на 10,38\%, в 1 У группе - 2,99\%, в У группе - на 3,16\%, чем в контрольной группе, где были сосредоточены отстающие в росте щенята, не получавшие экологически безопасные препараты (таблица 56).

Таблица 56

Влияние биологически активных веществ на сохранность

подопытных щенят лисиц

\begin{tabular}{|l|c|c|c|c|c|c|c|}
\hline \multirow{2}{*}{ Группы } & \multirow{2}{*}{$\mathrm{n}$} & \multicolumn{2}{l|}{$\begin{array}{l}\text { Отход щенят } \\
\text { на день }\end{array}$} & \multicolumn{2}{l|}{$\begin{array}{l}\text { Отход щенят } \\
\text { после }\end{array}$} & $\begin{array}{l}\text { Кол-во } \\
\text { щенят, } \\
\text { голов }\end{array}$ & $\begin{array}{c}\text { Сохран- } \\
\text { ность, \% }\end{array}$ \\
\cline { 2 - 6 } & & $\mathrm{n}$ & $\%$ & $\mathrm{n}$ & $\%$ & & \\
\hline $\mathbf{1}$ к. & 23 & 7 & 30,43 & 5 & 21,73 & 11 & 47,82 \\
П о. & 23 & 6 & 26,08 & 2 & 8,69 & 15 & 65,21 \\
Ш о. & 22 & 5 & 22.72 & 3 & 13.63 & 14 & 63.63 \\
1 1У о. & 24 & 7 & 29.16 & 4 & 16.66 & 13 & 54.16 \\
У о. & 22 & 6 & 27.27 & 4 & 18.18 & 12 & 54.54 \\
& & & & & & & \\
\hline
\end{tabular}

Отход щенят опытной группы после отсадки был меньшим по сравнению с контрольной группой в Ш группе на $8,1 \%$, в 1 У группе на $5,07 \%$, в У группе на 3,55\%. Сохранность к концу опыта составила в опытных группах, получавших биологически активные вещества $54,16-65,21 \%$, что больше чем в контроле, где сохранность составила 47,82\%.

Судя по полученным результатам, стимуляция гипотрофичных щенят биологически активными веществами в условиях Республики Саха (Якутия) дает наиболее отчетливый ростостимулирующий эффект при даче лисицам на 40-й день жизни 40,0 мг янтарной кислоты на I кг живой массы.

Наши наблюдения согласуются с исследованиями, проведенными на 
клеточных пушных зверях, сельскохозяйственных животных с использованием биологически активных веществ (Свечин Ю.К., Егорова А.Г., 1989; Балакирев Н.А., 1991, 1997, 2006; Борисова Н.Н.,Новикова Н.Н., Киселев В.Л., 1988, 1999, 2001, 2004; Квартникова Е.Г.,2002; Владимиров А.В., 2002 и др.).

Включение парааминобензойной кислоты, сукцината хитозана, янтарной кислоты и цеолита в рацион отстающим в росте щенятам лисиц повышает гемоэритропоэтическую функцию их организма (таблица 57).

Таблица 57

Гематологические показатели крови щенят лисиц, n-4

\begin{tabular}{|l|l|c|c|c|c|c|}
\hline \multicolumn{1}{|c|}{ Показате } & Воз & \multicolumn{5}{|c|}{ Группы } \\
\cline { 5 - 8 } & pac & I & II & Ш & $1 \mathrm{~V}$ & У \\
& т & к. & o. & o. & o. & o. \\
\hline Эритроциты & 2 & $7,09 \pm 0,84$ & $7,32 \pm 0,51$ & $7,12 \pm 0,39$ & $7,35 \pm 0,44$ & $7,28 \pm 0,51$ \\
,млн./мм & 4 & $8,43 \pm 0,51$ & $9,08 \pm 0,61$ & $8,89 \pm 0,51$ & $9.66 \pm 0,39$ & $9,46 \pm 0,28$ \\
Лейкоциты & 2 & $7,01 \pm 0,62$ & $7,23 \pm 0,42$ & $7,15 \pm 0,24$ & $7.54 \pm 0,34$ & $7,34 \pm 0,62$ \\
тыс /мм & 4 & $6,09 \pm 0,71$ & $6,99 \pm 0,64$ & $6,28 \pm 0,58$ & $7.33 \pm 0.59$ & $7,18 \pm 0,45$ \\
Гемоглобин, & 2 & $7,33 \pm 3,15$ & $9,65 \pm 4,11$ & $9,45 \pm 5,21$ & $9.81 \pm 3.99$ & $8,49 \pm 4,03$ \\
г100мл & 4 & $13,15 \pm 4,48$ & $14,42 \pm 4,58$ & $14,26 \pm 3,01$ & $14.71 \pm 3.56$ & $13,38 \pm 3,52$ \\
\hline
\end{tabular}

${ }^{\mathrm{x}}-\mathrm{P}>0,95 ;^{\mathrm{xx}}-\mathrm{P}>0,99 ;^{\mathrm{xxx}}-\mathrm{P}>0,999$

В крови щенят лисиц опытных групп увеличилась концентрация гемоглобина в 2-месячном возрасте на 1,16-2,48г/100мл., в 4-месячном возрасте на 0,23-1,56 г/100мл, по сравнению с контрольной группой. Содержание в крови эритроцитов было больше по сравнению с аналогичными показателями контрольной группы, где находились отстающие в росте щенки - в 2-месячном возрасте - на 0,23-0,30 млн./мм3, в 4-месячном возрасте - на 
0,46-1,23 млн./мм3. Это указывает на повышение дыхательной функции эритроцитов, что обусловлено увеличением потребности организма в кислороде и активацией окислительно-восстановительных процессов у щенят опытных групп.

Белковый состав крови зверей, получавших парааминобензойную кислоту, сукцинат хитозана, янтарную кислоту и цеолит, также свидетельствует об улучшении их общего физиологического состояния организма (таблица 58). Содержание общего белка в сыворотке крови зверей опытных групп было выше в 2 месячном возрасте на 0,29-0,66г/100мл, в 4 месячном возрасте на 0,18-0,38г/100мл, чем в крови зверей контрольной группы. Увеличение белка шло за счет гамма-глобулиновой фракции, являющейся носителем антител, что свидетельствует об усилении иммунобиологических свойств организма, в связи с воздействием на него ПАБК, СХ, ЯК и цеолит. В соответствии с этим и белковый коэффициент в опытной группе был меньше. В возрасте 2 месяцев у щенят П-1У опытных групп данный коэффициент был равен 1,42-1,49, тогда как в контрольной группе $-1,68$.

В 4 месячном возрасте количество альбуминов продолжило снижаться: белковый коэффициент в опытных группах равнялся 1,41-1,49 (в контрольной $-1,92)$.

В 2-месячном возрасте $\gamma$-глобулиновой фракции было больше в крови зверей опытных групп на 4,32-4,53\%, в возрасте 4 месяцев на 5,59-6,92\% $(\mathrm{P}>0,95)$. Наши данные подтвердили материалы, полученные В.А.Берестовым (1967, 2005), Р.Г.Дубовой (1973, 1975), Е.П.Даниловым, Р.Г.Дубовой (1978). Высокая активность белкового обмена, при использовании биологически активных веществ, подтверждается и высокой утилизацией белков плазмы крови, особенно ее резервных белков - альбуминов, выполняющих питательно-пластическую функцию, интенсивно транспортирующих биологически активные вещества. Стимуляция белкового обмена за счет 
применения биологически активных веществ способствовала более интенсивному росту и развитию, повышению прироста массы тела у подопытных щенят. Этим, по-видимому, и объясняется тот дополнительный ростовой эффект, который был получен от воздействия парааминобензойной кислоты, сукцината хитозана, янтарной кислоты и цеолита.

Итоги бонитировки показали, что щенята опытных групп получали за размер тела более высокие оценки - в среднем 5-7 баллов. Наиболее высокие баллы за этот показатель были в опытах у щенят, получавших янтарную кислоту. Средний балл за размер тела и телосложение у самок был выше на 0,27-0,74 балла или на 8,7-23,87\%, у самцов на 0,21-0,52 балла или на 6,1415,2\%, по сравнению с контрольной группой (таблица 59).

Средний балл за качество опушения у самок был выше на 0,01-0,39 балла или на 0,27-10,83\%, у самцов на 0,04-0,24 балла или на 1,12-6,72\%. Окраска волосяного покрова самок была оценена на 0,07-0,3 балла или на 1,91-8,19\%, самцов на 0,15-0,44балла или на 4,28-12,57\% выше, чем у щенков контрольных групп.

Классность лисиц опытных групп была выше, чем в контрольной группе, где ПАБК, СХ, ЯК и цеолит звери не получали.

Нами изучалась структура волосяного покрова у контрольной и опытных групп молодняка серебристо-черных лисиц. Установлено, что длина остевых волос, вуали, пуха, размер кольца и \% платиновых волос существенно не отличались в зависимости от препарата биологически активного вещества (таблица 60).

Общеизвестно, что желудочно-кишечный тракт, органы кровообращения, дыхания и другие являются звеньями единой системы и изменение в одной из них влечет за собой изменение и в других органах и системах. Опытами Д.И. Грудева (1970), В.Ф. Филенко (1975), В.Д. Кабанова (1961) установлено, что интенсивность роста основных тканей совпадает с интенсивностью роста всех органов. 
Сердце является центральным органом кровообращения, так как осуществляет циркуляцию крови по замкнутым (большому и малому) кругам сосудов. Нарушения со стороны сердца часто вызывают легочную дисфункцию из-за близких структурных и функциональных взаимоотношений между этими жизненноважными органами (Шумилина H.H., 2005).

Легкие осуществляют газообмен между внешней средой и кровью организма и относятся к органам дыхания. Заболевания этих органов способны вызывать отставание в росте животных.

Основная функция почек заключается в удалении из организма конечных продуктов обмена путем сложного процесса мочеобразования. Кроме того, почки регулируют осмотическое давление крови и кислотно-щелочное равновесие.

Путем взвешивания и измерения было определено развитие внутренних органов зверей опытных и контрольной групп (таблица 61).

Масса сердца щенят П.Ш и 1У опытных групп больше на 3,12-5,0г или на 6,93-11,11\%, чем в контроле. Масса легких щенят опытных групп больше на 0,65-4,38г или на 1,42-9,60\%, чем в 1 группе. Также была больше масса печени на 0,64-3,32\%, желудка (П, Ш. 1У группе) на 9,45-21,52\%, почек (П, Ш, У группы) на 3,61-12,88\%, чем в контрольной группе гипотрофичных щенят, не получавших биологически активные вещества. В опыте измеряли длину кишечника щенят контрольной и опытных групп, в пользу последнего $0,26-2,76 \%$.

При этом отмечено, что в процессе роста между живой массой щенят лисиц и массой внутренних органов наблюдается прямая зависимость. Это совпадает с исследованиями, проведенными на норках и отстающих в росте поросятах (Самков Ю.А., Перельдик Н.Ш. и др., 1979). При вскрытии лисиц опытных и контрольной групп не выявлено изменений морфологической картины их внутренних органов и тканей. 
Печень. Классической морфофункциональной единицей печени является печеночная долька, состоящая из печеночных балок, составленных гепатоцитами. Между печеночными балками проходят внутридольковые синусоиды, по которым артериальная и венозная кровь из портальной артерии и вены проходят через печеночную дольку и поступает в центральные и собирательные вены, выносящие кровь из печени. По периферии долек выявляются участки соединительной ткани, в которой проходят ветви артерии, портальной вены, лимфатический сосуд и желчные протоки.

У подопытных животных печеночные балки располагаются близко друг от друга. Синусоиды, выстланные плоскими купферовскими клетками, узкие и содержат единичные эритроциты. Гепатоциты имеют полигональную форму, плазмолемма очерчена нечетко. Печеночные клетки содержат округлое умеренно базофильное ядро с глыбками хроматина и хорошо выраженными одним или двумя ядрышками. В эозинофильной цитоплазме гепатоцитов выявляются рибонуклеопротеиновые глыбки, наиболее характерные для клеток, которые расположены по периферии долек.

При окрашивании печени после ее фиксации в жидкости Карнуа ШИК реакцией на гликоген, продукт реакции зернистого темно-розового цвета выявляется в цитоплазме гепатоцитов. Обнаруживается характерная для интактных животных мозаичность локализации гликогена. В одних случаях отложения гликогена преобладают в центральной части долек, в других, наоборот, в перипортальной зоне. Однако при окрашивании ШИК реакцией в печеночных клетках животных опытных групп выявляется значительно большее накопление гликогена. При этом гликоген распределяется в дольках более равномерно, а продукт реакции имеет более интенсивную окраску .

Селезенка является периферическим лимфоидным органом, который контролирует поступление антигена гематогенным путем. Лимфоидные структуры связаны с белой пульпой, где содержатся В- и Т-зависимые зоны (соответственно фолликулы и периартериалъные муфты), участки, где 
плазматические клетки секретируют антитела.

У подопытных животных гистологический рисунок селезенки соответствует вариантам нормы. Соединительно-тканная капсула тонкая. Трабекулы отходят от капсулы в виде узких волокнистых тяжей. Ретикулярная ткань, образующая строму красной и белой пульпы, состоит из ретикулярных клеток, волокон и фибробластов. Белая пульпа представлена совокупностью лимфоидных периартериальных муфт и лимфатических фолликулов правильной округлой формы.

Маргинальные зоны определяются в виде перифолликулярных колец и плотно заполнены ретикулярными клетками, крупными лимфоцитами и макрофагами.

Красная пульпа состоит из пульпарных тяжей и венозных синусов, заполненных форменными элементами крови. В субкапсулярной зоне и вдоль трабекул располагаются небольшие по размерам очаги миелоидного кроветворения. Они имеют нечеткую, иногда разветвленную форму, разную величину и содержат бластные формы миелоидного кроветворения. В островках кроветворения определяются небольшие группы или единичные молодые нейтрофилы и эозинофилы, реже встречаются островки эритроцитарного кроветворения и мегакариоциты.

У животных опытных групп макроскопически селезенка увеличена в размерах и полнокровна. Гистологически определяются признаки гиперплазии лимфоидных элементов в герминативных центрах фолликулов и активизация зон экстрамедуллярного кроветворения. У всех животных опытных групп лимфоидные фолликулы и их центры размножения увеличены в размерах. При гистологическом исследовании отмечено, что парааминобензойная кислота, сукцинат хитозана, янтарная кислота и цеолит влияют на выработку гуморальных антител. Биологически активные вещества усиливают образование в лимфотических фолликулах селезенки центров клеточного размножения. Количество таких центров зависело от препарата. 
Работами А.Хэм, Д.Кормак (1983) показано, что большое количество лимфотических фолликулов с крупными центрами клеточного размножения указывает на хороший, напряженный гуморальный иммунитет. Определяется активация клеток и в тимусзависимых участков перифолликулярной ткани маргинальных зонах. В участках экстрамедуллярного кроветворения красной пульпы среди дифференцирующихся лейкоцитов зрелых клеточных форм выявляется меньше.

В совокупности указанные гистологические признаки свидетельствуют об активизации пролиферативного процесса как в лимфоидных фолликулах, так и в очагах миелоидного кроветворения. В последних, по-видимому, происходит и более интенсивное созревание и миграция форменных элементов крови.

По гистологическим показателям, объективно регистрируемые изменения выявлены в большинстве изученных органов. Эти изменения можно суммировать следующим образом: в печени регистрируются гистохимические признаки усиления синтеза гликогена; по гистологическим признакам активируется лимфопоэз в лимфатических фолликулах селезенки, кроме того, в селезенке, по-видимому, наблюдается усиление экстрамедуллярного миелопоэза.

При анализе качества шкурковой продукции лисиц выяснено, что вследствие повышенной живой массы к моменту забоя, длина шкурок самок и самцов опытных групп была значительно больше (самок на 1,17-4,86\%, самцов на $1,16-4,70 \%)$, чем в контрольной группе. Это подтверждает мнение Н.И.Сырникова, А.Г.Корченкова $(1974,1977)$ и Pigel H., Schumacher J., Zunft Р. (1986) о том, что размер шкурок пушных зверей больше зависит от их живой массы (таблица 62). 
Размер шкурок подопытного молодняка лисиц, n-4

\begin{tabular}{|c|c|c|c|}
\hline Группы & Пол & Длина шкурок, см & Площадь шкурок, см² \\
\hline \multirow[t]{2}{*}{ I к. } & q & $79,31 \pm 1,33$ & $1982,75 \pm 31,63$ \\
\hline & $\widehat{0}$ & $83,45 \pm 1,15$ & $2086,25 \pm 26,42$ \\
\hline \multirow[t]{2}{*}{ II o. } & q & $81,36 \pm 1,27$ & $2034,00 \pm 32,67$ \\
\hline & ठ & $86,26 \pm 0,81$ & $2156,50 \pm 18,84$ \\
\hline \multirow[t]{2}{*}{ Ш о. } & q & $80,24 \pm 1,16$ & $2006,00 \pm 31,44$ \\
\hline & $\sigma^{\lambda}$ & $84,73 \pm 1,09$ & $2118,25 \pm 17,52$ \\
\hline \multirow[t]{2}{*}{$1 \mathrm{~V} \mathrm{o.}$} & q & $83,17 \pm 1,26$ & $2079,25 \pm 28,36$ \\
\hline & $\sigma^{\lambda}$ & $87,38 \pm 1,52$ & $2184,50 \pm 14,65$ \\
\hline \multirow[t]{2}{*}{ У o. } & q & $80,54 \pm 1,54$ & $2011,50 \pm 37,41$ \\
\hline & $\sigma^{\lambda}$ & $84,42 \pm 0,59$ & $2108,50 \pm 13,52$ \\
\hline
\end{tabular}

По степени дефектности волосяного покрова шкурки, полученные от опытных зверей были лучше, чем шкурки от особей отстающей в росте группы. Среди 1У, У опытных групп было больше нормальных бездефектных и с малым дефектом шкурок - 50,00-62,50\%, тогда как в контрольной группе таких шкурок было - 37,50\%. Потери на дефектах были наименьшими в опыте в опытных группах (таблица 63).

Учитывая, что используемые биологически активные вещества принимают участие в регуляции обмена веществ, следует предположить, что улучшение качества шкурок подопытных лисиц связано именно с этим явлением. Зачет шкурок по качеству в группах, щенята в которых получали добавку парааминобензойной кислоты составлял 66,58 \%, сукцинат хитозана $66,04 \%$, янтарной кислоты - 66,97\%, цеолита - 66,84\%, тогда как в контрольной группе $-63,67 \%$.

Зачет по качеству шкурок в опытных группах в среднем был выше, чем в контрольной группе на 2,36 - 3,30\% (таблица 64). Соответственно была 
выше и цена шкурок опытных групп - на 59,0-83,0 руб. Лучшие результаты получены в опытной группе, в которой щенята получали янтарную кислоту,

Таблица 63

Качественные показатели шкурок лисиц контрольной и опытных групп

\begin{tabular}{|l|c|c|c|c|c|c|}
\hline \multirow{2}{*}{ Группы } & \multicolumn{6}{|c|}{ Количество и удельная масса шкурок } \\
\cline { 2 - 7 } & \multicolumn{2}{|c|}{ Нормальных } & \multicolumn{3}{|c|}{ Малый дефект } & \multicolumn{1}{c|}{ Средний дефект } \\
\cline { 2 - 7 } & & $\%$ & шт. & $\%$ & шт. & $\%$ \\
\hline I к. & 3 & 37,50 & 2 & 25,00 & 3 & 37,50 \\
II o. & 3 & 37,50 & 4 & 50,00 & 1 & 12,50 \\
Ш о. & 3 & 37,50 & 3 & 37,50 & 2 & 25,00 \\
IV o. & 5 & 62,50 & 2 & 25,00 & 1 & 12,50 \\
У o. & 4 & 50,00 & 2 & 25,00 & 2 & 25,00 \\
\hline
\end{tabular}

средняя реализационная цена шкурки составила 1675,00 руб., тогда как в контрольной группе лишь 1592,00 руб. Аналогичные результаты о положительном влиянии стимуляторов на качество волосяного покрова даны в работах Н.А. Балакирева (1997), О.Л.Рапопорта, М.А. Голушковой (1989), П.П.Орлова, П.А.Бурдель, Б.Ф.Дужко (1989) и других.

В результате полученных нами данных установлено, что парааминобензойная кислота, сукцинат хитозана, янтарная кислота и цеолит оказывают положительное влияние на отстающих в росте и развитии щенят лисиц.

Лучшие результаты по стимуляции роста щенят лисиц получены при введении им в корм янтарной кислоты на 40-день жизни в дозе 40,0 мг на I кг живой массы.

Таблица 64

Зачет по качеству и цена шкурок контрольной и опытных групп лисиц 


\begin{tabular}{|l|c|c|}
\hline \multirow{2}{*}{ Группы } & \multicolumn{2}{|c|}{ В среднем по группе } \\
\cline { 2 - 3 } & Зачет по качеству,\% & Ср. цена, руб \\
\hline 1 к. & 63,67 & 1592,00 \\
П о. & 66,58 & 1665,00 \\
Ш о. & 66,04 & 1651,00 \\
1 У о. & 66,97 & 1675,00 \\
У о. & 66,84 & 1671,00 \\
& & \\
\hline
\end{tabular}

В проведенном двухфакторном дисперсионном анализе было изучено влияние оптимальных доз биологически активных веществ на живую массу, сохранность молодняка и размер шкурок гипотрофичного молодняка лисиц (таблица 65). Анализ полученных результатов свидетельствует, что

Таблица 65

Дисперсионный анализ оптимального биологически активного вещества

\begin{tabular}{|l|l|c|c|}
\hline Группы & \multicolumn{1}{|c|}{ Препараты } & Дозы & Дисперсия \\
\hline 1 к. & \multicolumn{1}{|c|}{-} & - & 1526,7865 \\
П о. & парааминобензойная кислота & 1,0 мг|кг & 1693,3681 \\
Ш о. & сукцинат хитозана & 1,0 мг|кг & 1591,3870 \\
$1 У$ о. & янтарная кислота & 40 мг|кг & 1786,5813 \\
У о. & цеолит & $5,0 \Gamma$ & 1744,4314 \\
\hline
\end{tabular}

оптимальные дозы цеолита, янтарной кислоты, парааминобензойной кислоты и сукцината хитозана оказали положительное влияние на изучаемые показатели. Лучшим препаратом для стимуляции роста и развития гипотрофичного молодняка лисиц является янтарная кислота в дозе 40 мг/кг живой массы. Разница между полученными результатами в опыте достоверна $\left(\mathrm{F}_{\text {факт. }}=4,02 ; \mathrm{F}_{\text {табл. }}=3,83\right), \quad$ так как $\mathrm{F}_{\text {факт. }}>\mathrm{F}_{\text {.табл. }}$. Полученные данные 
исследований в У опыте подтвердились еще раз результатами дисперсионного анализа.

Таким образом, результаты наших исследований показывают перспективность применения парааминобензойной кислоты, сукцината хитозана, янтарной кислоты и цеолита в клеточном звероводстве Республики Саха (Якутия) для стимуляции роста и развития гипотрофичного молодняка зверей клеточного разведения. 
Таблица 53

Динамика живой массы, длины тела и обхвата груди подопытного молодняка лисиц

\begin{tabular}{|c|c|c|c|c|c|c|c|}
\hline \multirow[t]{2}{*}{ Показатели } & \multirow{2}{*}{$\begin{array}{c}\text { Возраст, } \\
\text { мес. }\end{array}$} & \multirow[b]{2}{*}{ Пол } & \multicolumn{5}{|c|}{ Группы } \\
\hline & & & $\begin{array}{c}1 \\
\text { к. }\end{array}$ & $\begin{array}{l}\Pi \\
\text { о. }\end{array}$ & $\begin{array}{c}\text { Ш } \\
\text { о. }\end{array}$ & $\begin{array}{c}\text { IV } \\
\text { o. }\end{array}$ & $\begin{array}{l}\mathrm{y} \\
\mathrm{o} .\end{array}$ \\
\hline \multirow[t]{4}{*}{ Живая масса, кг } & \multirow[t]{2}{*}{1} & $q$ & $0,69 \pm 0,03$ & $0,75 \pm 0,04$ & $0,73 \pm 0,03$ & $0,70 \pm 0,04$ & $0,73 \pm 0,03$ \\
\hline & & 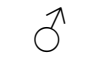 & $0,71 \pm 0,04$ & $0,77 \pm 0,03$ & $0,75 \pm 0,02$ & $0,72 \pm 0,02$ & $0,76 \pm 0,02$ \\
\hline & \multirow[t]{2}{*}{4} & o & $3,47 \pm 0,07$ & $3,83 \pm 0,09^{\mathrm{xx}}$ & $3.69 \pm 0,05^{\mathrm{x}}$ & $3.95 \pm 0,09^{\mathrm{xxx}}$ & $3,78 \pm 0,06$ \\
\hline & & $0^{\pi}$ & $3,50 \pm 0,05$ & $3,84 \pm 0,07^{\mathrm{xx}}$ & $3.72 \pm 0,07^{x}$ & $4.09 \pm 0.13 \mathrm{xxx}$ & $3,79 \pm 0,09$ \\
\hline \multirow[t]{4}{*}{ Длина тела, см } & \multirow[t]{2}{*}{1} & q & $29,79 \pm 0,34$ & $30,15 \pm 0,29$ & $29.03 \pm 0,58$ & $30.05 \pm 0,52$ & $29,13 \pm 0,46$ \\
\hline & & $\hat{0}$ & $29,72 \pm 0,40$ & $30,08 \pm 0,15$ & $29.15 \pm 0,23$ & $29.64 \pm 0,39$ & $29,54 \pm 0,51$ \\
\hline & \multirow[t]{2}{*}{4} & q & $50,83 \pm 0,53$ & $52,33 \pm 0,60$ & $52.98 \pm 0,71$ & $55.91 \pm 0,66^{\mathrm{xxx}}$ & $53,39 \pm 0,57^{x}$ \\
\hline & & o & $52,53 \pm 0,40$ & $54,45 \pm 0,37^{x x}$ & $55.95 \pm 0,50^{\mathrm{xxx}}$ & $57.74 \pm 0,52^{\mathrm{xxx}}$ & $55,29 \pm 0,32^{\mathrm{x}}$ \\
\hline \multirow[t]{4}{*}{ Обхват груди, см } & \multirow[t]{2}{*}{1} & q & $18,54 \pm 0,19$ & $17,11 \pm 0,81$ & $17.72 \pm 0,71$ & $18.34 \pm 0,52$ & $17,97 \pm 0,39$ \\
\hline & & $\sigma^{\lambda}$ & $19,09 \pm 0,21$ & $18,69 \pm 0,34$ & $18,51 \pm 0,42$ & $18,58 \pm 0,64$ & $18,78 \pm 0,27$ \\
\hline & \multirow[t]{2}{*}{4} & q & $33,07 \pm 0,33$ & $34,99 \pm 0,57^{\mathrm{xx}}$ & $34.12 \pm 0,38$ & $36.04 \pm 0,41^{\mathrm{xxx}}$ & $34,21 \pm 0,46^{\mathrm{x}}$ \\
\hline & & $0^{\pi}$ & $35,18 \pm 0,58$ & $36,81 \pm 0,26^{x}$ & $36.05 \pm 0,42$ & $37.36 \pm 0,21^{\mathrm{xx}}$ & $36,49 \pm 0,28^{x}$ \\
\hline
\end{tabular}


Таблица 55

Индексы телосложения лисиц контрольной и опытных групп

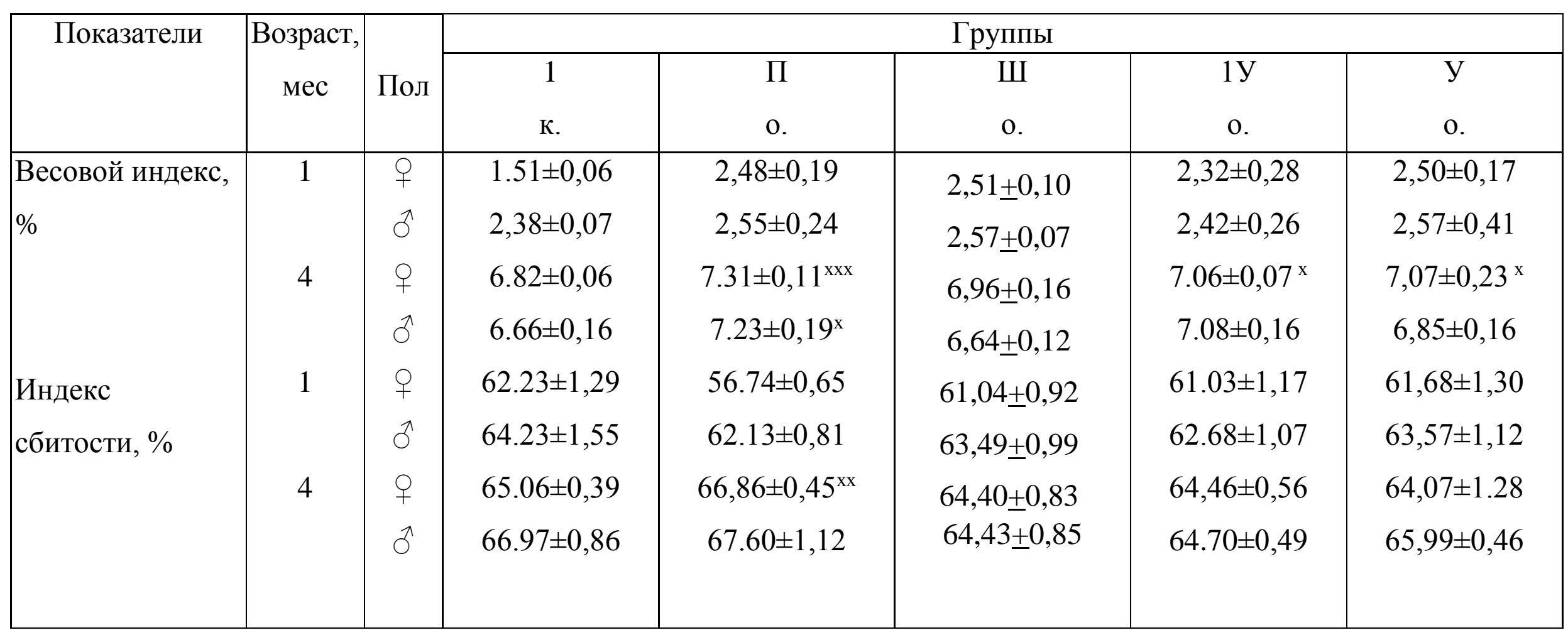

$\mathrm{x}_{-} \mathrm{P}>0,95 ;{ }^{\mathrm{xx}}-\mathrm{P}>0,99 ;{ }^{\mathrm{xxx}}-\mathrm{P}>0,999$ 
Содержание общего белка и его фракций в сыворотке крови молодняка лисиц, n-4

\begin{tabular}{|c|c|c|c|c|c|c|}
\hline \multirow[t]{2}{*}{ Показатели } & \multirow{2}{*}{$\begin{array}{c}\text { Возраст, } \\
\text { мес }\end{array}$} & \multicolumn{5}{|c|}{ Группы } \\
\hline & & І К к. & II o. & Ш о. & 1V o. & Уo. \\
\hline Общий белок, & 2 & $5.71 \pm 2,88$ & $6.22 \pm 1,00$ & $6,00 \pm 3,53$ & $6.31 \pm 1,54$ & $6,37 \pm 1,15$ \\
\hline г/100мл & 4 & $6.31 \pm 1,17$ & $6.49 \pm 2,63$ & $6,51 \pm 3,00$ & $6.64 \pm 2,22$ & $6,69 \pm 2,15$ \\
\hline Альбумины, \% & 2 & $62.51 \pm 1,70$ & $58.34 \pm 2,38$ & $59,15 \pm 1,97$ & $59.61 \pm 1,68$ & $62,54 \pm 1,37$ \\
\hline & 4 & $65.60 \pm 1,15$ & $59.34 \pm 1,44$ & $58,57 \pm 5,49$ & $58.15 \pm 1,76$ & $59,37 \pm 1,24$ \\
\hline Глобулины, \% & 2 & $37.14 \pm 1,70$ & $41.07 \pm 2,38$ & $40,28 \pm 1,97$ & $39.96 \pm 1,68$ & $36,64 \pm 1,52$ \\
\hline & 4 & $34.05 \pm 1,15$ & $39.74 \pm 1,44^{\mathrm{xx}}$ & $40,55 \pm 5,49$ & $41.19 \pm 1,70 \mathrm{x}$ & $40,04 \pm 1,64^{\mathrm{xx}}$ \\
\hline $\mathrm{A} / \Gamma$ & 2 & $1.68 \pm 0,20$ & $1.42 \pm 0,27$ & $1,46 \pm 0,20$ & $1.49 \pm 0,16$ & $1,69 \pm 0,47$ \\
\hline а_-гпобупше о & 4 & $1.92 \pm 0,11$ & $1,49 \pm 0,07$ & $1,44 \pm 0,22$ & $1,41 \pm 0,14$ & $1,48 \pm 0,25$ \\
\hline & 2 & $8.00 \pm 1,32$ & $7.58 \pm 2,01$ & $7,49 \pm 1,88$ & $7.64 \pm 2,05$ & $6,92 \pm 1,72$ \\
\hline$\beta$ - глобулин. \% & 4 & $7.59 \pm 0,81$ & $7.15 \pm 1,5$ & $7,39 \pm 2,32$ & $7.71 \pm 2,49$ & $7,05 \pm 2,49$ \\
\hline & 2 & $21.15 \pm 1,03$ & $21.08 \pm 1,91$ & $20,48 \pm 1,31$ & $19.98 \pm 1,65$ & $17,64 \pm 1,52$ \\
\hline ү- глобулин, \% & 4 & $14.90 \pm 1,29$ & $15.44+1.21$ & $14,68 \pm 1,03$ & $15.09 \pm 1,32$ & $14,78 \pm 1,45$ \\
\hline & 2 & $7.99 \pm 1,77$ & $12.41 \pm 0,85$ & $12,31 \pm 3,19$ & $12.34 \pm 1,31$ & $13,55 \pm 1,28^{\mathrm{xxx}}$ \\
\hline & 4 & $11.56 \pm 2,08$ & $17.15 \pm 1,77$ & $18,48 \pm 0,85 x$ & $18.39 \pm 0,95 x$ & $17,84 \pm 1,47^{\mathrm{xxx}}$ \\
\hline
\end{tabular}


Таблица 61

Масса внутренних органов и длина кишечника подопытных щенят лисиц

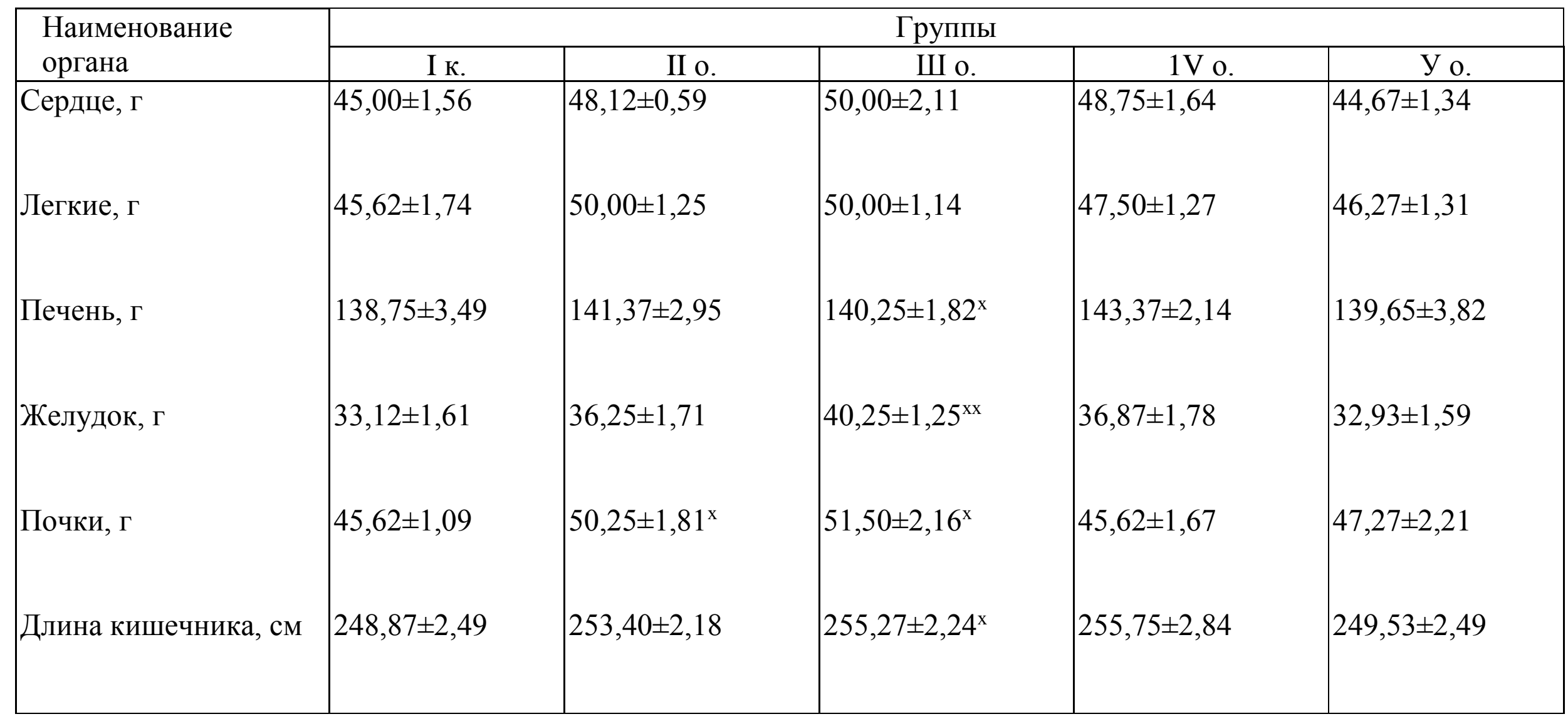

x-P>0,95;xx $-P>0,99 ;{ }^{x x x}-P>0,999$ 
Таблица 59

Результаты бонитировки подопытных лисиц в баллах

\begin{tabular}{|c|c|c|c|c|c|c|c|c|}
\hline Группы & $\mathrm{n}$ & $\begin{array}{c}\text { Размер и } \\
\text { телосложение }\end{array}$ & $\begin{array}{l}\text { Качество } \\
\text { опушения }\end{array}$ & $\begin{array}{c}\text { Окрас } \\
\text { волосяного } \\
\text { покрова }\end{array}$ & $\mathrm{n}$ & $\begin{array}{c}\text { Размер и } \\
\text { телосложение }\end{array}$ & $\begin{array}{l}\text { Качество } \\
\text { опушения }\end{array}$ & $\begin{array}{c}\text { Окрас } \\
\text { волосяного } \\
\text { покрова }\end{array}$ \\
\hline & \multicolumn{4}{|c|}{ Самки } & \multicolumn{4}{|c|}{ Самцы } \\
\hline 1 к. & 6 & $3,10 \pm 0,22$ & $3,60 \pm 0,22$ & $3,66 \pm 0,21$ & 7 & $3,42 \pm 0,20$ & $3,57 \pm 0,20$ & $3,50 \pm 0,33$ \\
\hline П о. & 8 & $3,37 \pm 0,18$ & $3,72 \pm 0,18$ & $3,75 \pm 0,16$ & 7 & $3,71 \pm 0,18$ & $3,61 \pm 0,18$ & $3,65 \pm 0,14$ \\
\hline Ш о. & 6 & $3,63 \pm 0,33$ & $3,66 \pm 0,21$ & $3,73 \pm 0,16$ & 6 & $3,63 \pm 0,24$ & $3,73 \pm 0,16$ & $3,73 \pm 0,46$ \\
\hline $1 \mathrm{Y} o$. & 6 & $3,84 \pm 0,33$ & $3,99 \pm 0,21$ & $3,96 \pm 0,21$ & 7 & $3,94 \pm 0,37$ & $3,69 \pm 0,18$ & $3,94 \pm 0,48$ \\
\hline Y o. & 5 & $3,71 \pm 0,21$ & $3,61 \pm 0,33$ & $3,84 \pm 0,56$ & 5 & $3,83 \pm 0,44$ & $3,81 \pm 0,47$ & $3,79 \pm 0,38$ \\
\hline
\end{tabular}

${ }^{\mathrm{x}}-\mathrm{P}>0,95 ; \mathrm{xx}-\mathrm{P}>0,99 ;{ }^{\mathrm{xxx}}-\mathrm{P}>0,999$ 
Таблица 60

Структура волосяного покрова подопытных лисиц

\begin{tabular}{|c|c|c|c|c|c|c|c|}
\hline Группы & $\mathrm{n}$ & Пол & $\begin{array}{c}\text { Длина ости, } \\
\text { мм }\end{array}$ & $\begin{array}{c}\text { Размер кольца, } \\
\text { мм }\end{array}$ & Вуаль, мм & $\begin{array}{c}\text { Длина пуха, } \\
\text { мм }\end{array}$ & $\begin{array}{c}\text { \% платиновых } \\
\text { волос }\end{array}$ \\
\hline \multirow[t]{2}{*}{1 к. } & 4 & q & $65,5 \pm 0.71$ & $10,8 \pm 0,34$ & $7,7 \pm 0,11$ & $46,8 \pm 0,26$ & $44,6 \pm 0,41$ \\
\hline & 4 & त & $67,7 \pm 0,69$ & $11,5 \pm 0,41$ & $7,5 \pm 0,06$ & $48,5 \pm 0,35$ & $43,3 \pm 0,23$ \\
\hline \multirow[t]{2}{*}{ По. } & 4 & q & $66,0 \pm 0,58$ & $10,7 \pm 0,39$ & $7,2 \pm 0,06$ & $46,5 \pm 0,36$ & $42,8 \pm 0,47$ \\
\hline & 4 & ๙ & $67,1 \pm 0,73$ & $12,1 \pm 0,48$ & $7,5 \pm 0,09$ & $49,6 \pm 0,51$ & $43,2 \pm 0,51$ \\
\hline \multirow[t]{2}{*}{ Ш o. } & 4 & q & $66,4 \pm 0,57$ & $10,8 \pm 0,38$ & $7,1 \pm 0,11$ & $46,7 \pm 0,53$ & $45,5 \pm 0,39$ \\
\hline & 4 & 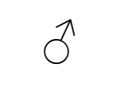 & $67,6 \pm 0,64$ & $11,7 \pm 0,44$ & $7,3 \pm 0,09$ & $48,7 \pm 0,33$ & $44,3 \pm 0,43$ \\
\hline \multirow[t]{2}{*}{$1 \mathrm{Y}_{\mathrm{o}}$} & 4 & q & $65,2 \pm 0,56$ & $12,1 \pm 0,29$ & $7,4 \pm 0,08$ & $45,9 \pm 0,42$ & $46,6 \pm 0,45$ \\
\hline & 4 & $\hat{0}$ & $66,8 \pm 0,67$ & $11,8 \pm 0,37$ & $7,6 \pm 0,08$ & $48,2 \pm 0,47$ & $43,8 \pm 0,25$ \\
\hline \multirow[t]{2}{*}{ У о. } & 4 & o & $64,7 \pm 0,62$ & $10,9 \pm 0,39$ & $7,5 \pm 0,07$ & $46,1 \pm 0,41$ & $45,3 \pm 0,41$ \\
\hline & 4 & o & $65,9 \pm 0,66$ & $12,3 \pm 0,41$ & $7,8 \pm 0,10$ & $49,2 \pm 0,26$ & $44,5 \pm 0,36$ \\
\hline
\end{tabular}




\section{4. Разведение норок в Якутии в 60-е годы XX века.}

Приказом № 14 от 13 января 1961 г. «О развитии звероводства» указало на необходимость: «наладить племенную работу на звероводческих фермах, увеличить количество видов разводимых зверей, обеспечить их правильное кормление и содержание, повысить требовательность к качеству пушнины. Расширить разведение цветной норки и норвежского голубого песца в зверосовхозах и на колхозных зверофермах. Довести к 1961 году выпуск шкурок цветной норки в зверосовхозах до 60 \% от общего количества шкурок норки.

В Якутии о возможности разведения стандартной норки были споры среди специалистов. Считали, что ввиду короткого меха с учетом обитания их в умеренном климате стандартные норки не могут акклиматизироваться в условиях холодного, резко континентального климата Якутии.

Инициаторами разведения норок в Якутии были заведующий лабораторией клеточного звероводства ЯНИИСХ кандидат ветеринарных наук В.И. Веселов, председатель колхоза им. Ленина МегиноКангаласского района М.Д. Петров, главный зоотехник этого колхоза И.П. Заболоцкий и младший научный сотрудник ЯНИИСХ Г.Н. Попов.

Впервые в суровых климатических условиях Якутии норками начали заниматься в колхозе им. Ленина Мегино-Кангаласского района Якутии с 28 декабря 1958 года. Звери были привезены из Седанского зверосовхоза Приморского края.

Привезенные из совхоза Седанки норки сразу попали в необычные условия содержания и кормления. В Седанке норки находились в условиях умеренного климата (до $20^{\circ} \mathrm{C}$ ) и кормили их преимущественно рыбными кормами. В Якутии они очутились в то время, когда морозы были около минус $60^{\circ} \mathrm{C}$. Взамен рыбных рационов их переключили на мясные корма.

Строительство сараев - шедов, а также специальной звероплощадки для норок колхоз сделать не успел. К моменту привоза зверей была сделана часть клеток с домиками и гнездами. Размер сетчатых клеток 
100x50x50, домиков 50x50x50, гнезд 35х35х35 см. Внутри прикрепленных к клеткам домикам вставляли гнезда, промежуток между гнездом и домиком утепляли сухим мхом. Внутри гнезда укладывали мох и сено. Изза опасения, что норки вследствие резкой смены температуры могут погибнуть, их содержали вначале в отапливаемом помещении, где температуру поддерживали в пределах минус 20-25, постепенно понижая ее до уличной. Для опыта 5 норок с первых же дней приезда содержали на улице. Последние хорошо перенесли низкую температуру Якутии, это позволило уже через неделю, приступить к переводу всего поголовья на уличное содержание. Январь месяц был холодным, минимальная температура достигала $-62^{\circ} \mathrm{C}$ при средней $-50 \ldots 55^{\circ} \mathrm{C}$ мороза. Норки не выходили из домиков, некоторые из них даже пропускали момент кормления. Корма они обычно быстро затаскивали в домики. По наблюдениям звероводов норки из домиков выходили в большинстве, в день 3-4 раза для испражнения или приема корма. В теплое время года, примерно при $-20 \ldots 30^{\circ} \mathrm{C}$ они часто выходят из домиков, ходят, лежат в клетке. Учитывая, что корма при сильных морозах быстро замерзают, а мерзлый корм звери почти не едят, норок начали зимой кормить не два, как принято в норководческих хозяйствах средних широт, а три раза в день. В первый год работы с норкой кормили их вволю.

Подготовка кормов к скармливанию проводилась только ручным способом. Мясо отделенное от костей рубили топором. Все корма смешивают в деревянной корыте лопатой. В силу того, что при подобном приготовлении масса корма неоднородна (сухая и рассыпается) при захвате его норками большая часть проваливалась через сетку. Вследствие этого значительное количество корма норками не поедалось. 
Таблица 61

Калорийность суточных рационов и процентное соотношение групп кормов у норок

\begin{tabular}{|c|c|c|c|c|c|c|c|}
\hline & \multirow{2}{*}{$\begin{array}{l}\text { Средне- } \\
\text { суточн. } \\
\text { на } 1 \\
\text { гол. } \\
\text { бол.кал. }\end{array}$} & \multicolumn{6}{|c|}{$\begin{array}{l}\text { Соотношение отдельных групп кормов } \\
\text { ( в \% от калорийности) }\end{array}$} \\
\hline & & $\begin{array}{l}\text { Мяс- } \\
\text { ные }\end{array}$ & $\begin{array}{l}\text { Молоч- } \\
\text { ные }\end{array}$ & $\begin{array}{l}\text { Зерно- } \\
\text { вые }\end{array}$ & $\begin{array}{l}\text { Овощ- } \\
\text { ные }\end{array}$ & $\begin{array}{l}\text { Дрож- } \\
\text { жи }\end{array}$ & $\begin{array}{l}\text { Рыб. } \\
\text { жир }\end{array}$ \\
\hline Январь & 304 & 70,96 & 6,77 & 10,64 & - & 8,63 & 3,0 \\
\hline Февраль & 266 & 71,78 & 6,58 & 12,64 & - & 5,60 & 3,40 \\
\hline Март & 220 & 42,27 & 7,73 & 22,27 & - & 23,22 & 4,51 \\
\hline Апрель & 335 & 61,67 & 11,83 & 6,93 & - & 16,80 & 2,77 \\
\hline Май & 298,2 & 59,44 & 16,80 & 7,02 & - & 14,74 & 2,0 \\
\hline Июнь & 338,1 & 61,78 & 17,84 & 7,57 & - & 10,19 & 2,0 \\
\hline Июль & 285,5 & 54,81 & 28,53 & 6,46 & - & 8,20 & 2,0 \\
\hline Август & 255,3 & 63,07 & 26,57 & - & - & 8,36 & 2,0 \\
\hline Сентябрь & 299,0 & 75,1 & 6,3 & - & 6,74 & 11,86 & - \\
\hline Октябрь & 390 & 90,30 & 1,29 & 4,53 & - & 3,88 & - \\
\hline Ноябрь & 309 & 78,4 & 4,9 & 10,2 & - & 6,5 & - \\
\hline Декабрь & 301 & 79,2 & 4,2 & 9,8 & - & 6,8 & - \\
\hline $\begin{array}{l}\text { В сред- } \\
\text { нем за } \\
\text { год }\end{array}$ & 293,4 & 64,32 & 13,62 & 8,01 & 0,55 & 12,05 & 1,45 \\
\hline
\end{tabular}

Взамен мясных кормов в апреле - сентябре месяцах скармливали творог, который поедался хорошо.

Из этой таблицы видно, что овощной группой кормов обеспечить норок не удалось. Недостаточно скормлено и зерновых кормов. Из животных кормов незначительное количество скормлено требухи и рыбы и в основном она была представлена, мускульным мясом, печенью и кровью.

В 1960 году в кормлении норок больших существенных изменений не произошло. В 1959 и 1960 гг. преимущественно скармливали доброкачественные, неиспорченные мясные корма. Недоброкачественные и испорченные корма скармливали лисицам. 
Таблица 62

Суточный рацион кормов на 1 голову норок в 1960 году

\begin{tabular}{|l|l|l|l|l|l|l|}
\hline \multirow{2}{*}{$\begin{array}{l}\text { Наименововани } \\
\text { кормов }\end{array}$} & \multicolumn{2}{|l|}{ Январь-февраль } & \multicolumn{2}{l|}{ С 25 февраля по } \\
25 марта
\end{tabular}

Уже в первый год работы с норками изменился срок гона. Если в Седанском совхозе он начинался с первых чисел февраля, то в колхозе имени Ленина гон норок начинался с начала марта и заканчивался 27 марта. В отличие от лисиц и песцов гон у норок проходит очень дружно. 
Таблица 63

Щенение и плодовитость зверей в зависимости от сроков покрытия

\begin{tabular}{|c|c|c|c|c|c|c|c|c|c|c|c|}
\hline \multirow[b]{2}{*}{$\begin{array}{l}\text { Дата } \\
\text { первого } \\
\text { покрытия }\end{array}$} & \multirow[b]{2}{*}{ 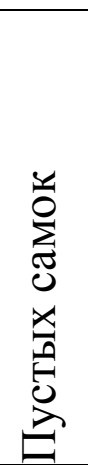 } & \multirow{2}{*}{ 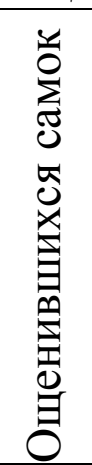 } & \multirow[b]{2}{*}{ 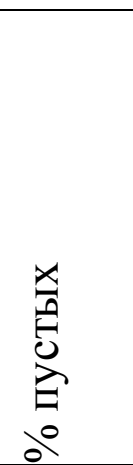 } & \multicolumn{2}{|c|}{$\begin{array}{l}\text { Кол-во } \\
\text { щенят }\end{array}$} & \multirow[b]{2}{*}{ 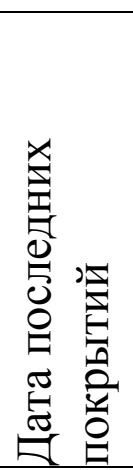 } & \multirow[b]{2}{*}{ 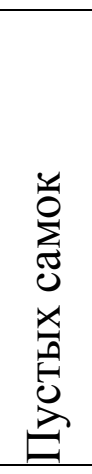 } & \multirow{2}{*}{ 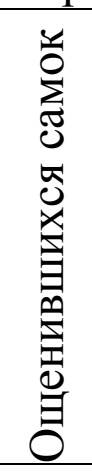 } & \multirow[b]{2}{*}{ 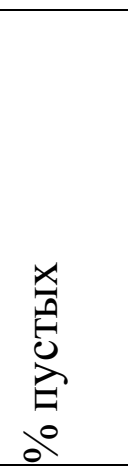 } & \multicolumn{2}{|c|}{$\begin{array}{l}\text { Кол-во } \\
\text { щенят }\end{array}$} \\
\hline & & & & 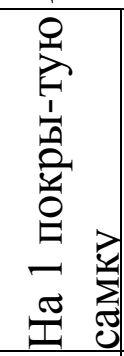 & 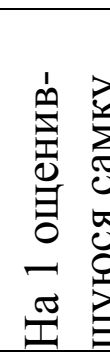 & & & & & 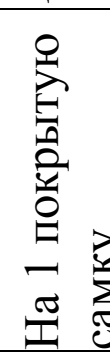 & 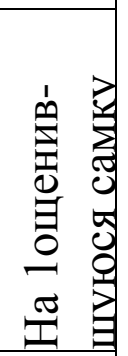 \\
\hline $\begin{array}{l}\text { До } 4 \\
\text { марта }\end{array}$ & 11 & 13 & 45,83 & 3,66 & 6,77 & $\begin{array}{l}\text { До } 11 \\
\text { марта }\end{array}$ & 1 & 2 & 33,3 & 5,33 & 8,0 \\
\hline $\begin{array}{l}\text { C } 4 \text { по } 10 \\
\text { марта }\end{array}$ & 7 & 34 & 17,07 & 4,34 & 5,23 & $\begin{array}{l}\text { С } 12 \\
\text { по } 20 \\
\text { марта }\end{array}$ & 18 & 47 & 27,6 & 3,98 & 5,51 \\
\hline $\begin{array}{l}\text { С } 11 \text { по } \\
15 \text { марта }\end{array}$ & 3 & 25 & 10,71 & 4,86 & 5,44 & C 21 & & & & & \\
\hline $\begin{array}{l}\text { C } 16 \text { по } \\
20 \text { марта }\end{array}$ & 1 & 9 & 10 & 3,9 & 4,33 & марта & 3 & 32 & 8,5 & 4,74 & 5,19 \\
\hline Итого & 22 & 81 & 21,36 & 4,28 & 5,44 & & 22 & 81 & 21,36 & 4,28 & 5,44 \\
\hline
\end{tabular}

Из этой таблицы видно, что первое покрытие до 4 марта дает 45,83 \% пустых от покрывшихся. Лучший срок первого покрытия с 4 марта по 15 марта, последнее покрытие с 20 марта по 27 марта. За этот период покрытия процент пропустовавших самок значительно уменьшается и на покрытую самку получается наибольшее количество щенят. Самцы норок были очень активны и в сезон делали до 19 покрытий, что видно из таблицы 64. 
Результаты проведения спаривания норок

Таблица 64

\begin{tabular}{|c|c|c|c|c|c|c|c|c|c|c|c|c|c|c|}
\hline \multirow{3}{*}{$\begin{array}{l}\text { №№ } \\
\text { самцов }\end{array}$} & \multicolumn{7}{|l|}{1959} & \multicolumn{7}{|l|}{1960} \\
\hline & \multirow[b]{2}{*}{$\begin{array}{l}\text { Всего } \\
\text { покры- } \\
\text { тий }\end{array}$} & \multirow[b]{2}{*}{$\begin{array}{l}\text { Покры- } \\
\text { то самок }\end{array}$} & \multirow[b]{2}{*}{$\begin{array}{l}\text { Из них } \\
\text { щени- } \\
\text { лись }\end{array}$} & \multirow[b]{2}{*}{$\begin{array}{l}\text { \% про- } \\
\text { пусто- } \\
\text { вав-ших }\end{array}$} & \multicolumn{3}{|c|}{ Получено щенят } & \multirow{2}{*}{$\begin{array}{l}\text { Всего } \\
\text { покры- } \\
\text { тий }\end{array}$} & \multirow[b]{2}{*}{$\begin{array}{l}\text { Покры- } \\
\text { то самок }\end{array}$} & \multirow[b]{2}{*}{$\begin{array}{l}\text { Из них } \\
\text { щени- } \\
\text { лись }\end{array}$} & \multirow[b]{2}{*}{$\begin{array}{l}\text { \% про- } \\
\text { пусто- } \\
\text { вав-ших }\end{array}$} & \multicolumn{3}{|c|}{ Получено щенят } \\
\hline & & & & & Всего & $\begin{array}{l}\text { На } \\
\text { родив } \\
\text { самку }\end{array}$ & $\begin{array}{l}\text { На покр. } \\
\text { самку }\end{array}$ & & & & & Всего & $\begin{array}{l}\text { На } \\
\text { родив } \\
\text { самку }\end{array}$ & $\begin{array}{l}\text { На покр. } \\
\text { самку }\end{array}$ \\
\hline 1 & 9 & 3 & 2 & 33,3 & 8 & 4 & 2,67 & 19 & 7 & 8 & - & 41 & 5,86 & 5,86 \\
\hline 3 & 13 & 7 & 3 & 15,14 & 14 & 4,67 & & 15 & 4 & 4 & - & 24 & 6 & 6,0 \\
\hline 5 & 7 & 3 & 3 & - & 13 & 4,3 & 4 & 3,12 & 2 & 2 & - & 11 & 5,5 & 5,5 \\
\hline 7 & 15 & 5 & 4 & 20 & 16 & 4 & 3,2 & 11 & 2 & 2 & - & 13 & 6,5 & 6,5 \\
\hline 9 & 17 & 6 & 4 & 33 & 3,27 & 6,75 & 4,5 & 19 & 6 & 5 & 16,67 & 32 & 6,4 & 5,33 \\
\hline 11 & 9 & 4 & 4 & - & 18 & 4,5 & 4,5 & 12 & 4 & 2 & 50 & 10 & 5,0 & 2,5 \\
\hline 13 & 6 & 3 & 3 & - & 16 & 5,33 & 5,33 & & & & & & & \\
\hline 15 & 13 & 5 & 3 & 40 & 12 & 4 & 2,4 & 15 & 3 & 2 & 33,3 & 6 & 3,0 & 2,0 \\
\hline 17 & 4 & 2 & 1 & 50 & 4 & 4 & 2,0 & & & & & & & \\
\hline 21 & & & & & & & & 14 & 5 & 5 & - & 31 & 6,2 & 6,2 \\
\hline 27 & & & & & & & & 14 & 4 & 4 & - & 23 & 5,75 & 5,75 \\
\hline 31 & & & & & & & & 11 & 2 & 2 & - & 14 & 7,0 & 7,0 \\
\hline 39 & & & & & & & & 12 & 3 & 2 & 33,3 & 11 & 5,5 & 3,66 \\
\hline 47 & & & & & & & & 15 & 4 & 4 & - & 22 & 5,5 & 5,5 \\
\hline 53 & & & & & & & & 18 & 6 & 5 & 16,67 & 29 & 5,8 & 4,8 \\
\hline 55 & & & & & & & & 15 & 3 & 2 & 33,3 & 13 & 6,5 & 4,33 \\
\hline 57 & & & & & & & & 11 & 3 & 2 & 33,3 & 7 & 3,5 & 2,33 \\
\hline 73 & & & & & & & & & & & & & & \\
\hline 75 & & & & & & & & 6 & 3 & 3 & - & 15 & 5 & 5 \\
\hline 99 & & & & & & & & 9 & 3 & 2 & 33,3 & 15 & 7,5 & 5 \\
\hline 101 & & & & & & & & 16 & 2 & 1 & 50 & 7 & 7 & 3,5 \\
\hline & 93 & 38 & 27 & 28,95 & 128 & 4,74 & 3,35 & 245 & 66 & 56 & 15,15 & 324 & 5,79 & 4,94 \\
\hline
\end{tabular}


Таблица 65

Производительность годовалых и двухлетних самок

\begin{tabular}{|c|c|c|c|c|c|c|c|c|c|c|c|c|c|c|c|c|c|c|c|}
\hline \multirow{2}{*}{\multicolumn{4}{|c|}{\begin{tabular}{|l|}
1959 \\
Самки однолетние \\
\end{tabular}}} & \multicolumn{8}{|c|}{1960} & \multicolumn{8}{|c|}{ В среднем за 2 года } \\
\hline & & & & $\mathrm{Cal}$ & и одн & ллетни & & Cam & и дВЈ & летни & & Can & и одн & олетні & & Can & си дв. & летни & \\
\hline \multirow[b]{2}{*}{ 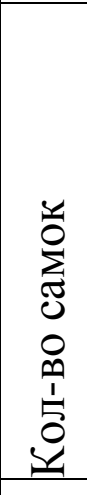 } & \multirow[b]{2}{*}{ 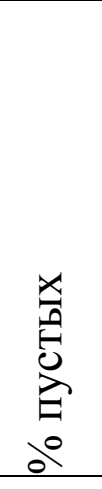 } & \multicolumn{2}{|c|}{$\begin{array}{l}\text { Получено } \\
\text { щенят }\end{array}$} & \multirow[b]{2}{*}{ 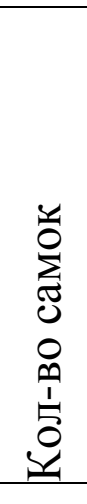 } & \multirow[b]{2}{*}{ 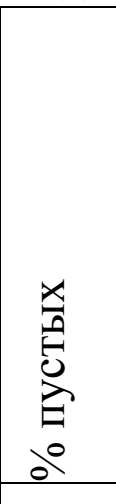 } & \multicolumn{2}{|c|}{$\begin{array}{l}\text { Получено } \\
\text { щенят }\end{array}$} & \multirow[b]{2}{*}{ 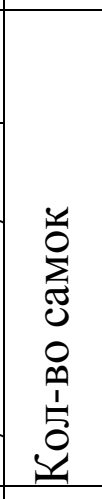 } & \multirow[b]{2}{*}{ 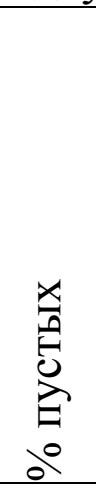 } & \multicolumn{2}{|c|}{$\begin{array}{l}\text { Получено } \\
\text { щенят }\end{array}$} & \multirow[b]{2}{*}{ 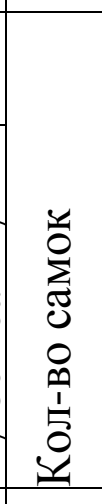 } & \multirow[b]{2}{*}{ 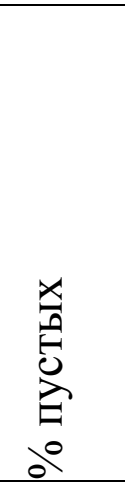 } & \multicolumn{2}{|c|}{$\begin{array}{l}\text { Получено } \\
\text { щенят }\end{array}$} & \multirow[b]{2}{*}{ 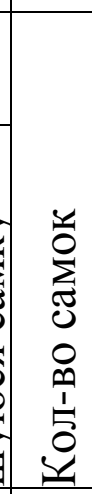 } & \multicolumn{3}{|c|}{$\begin{array}{l}\text { Получено } \\
\text { щенят }\end{array}$} \\
\hline & & 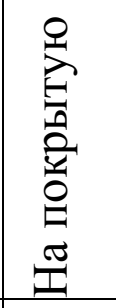 & 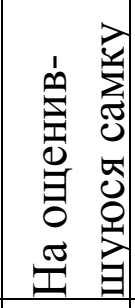 & & & 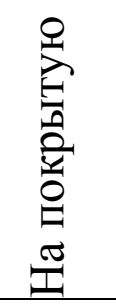 & 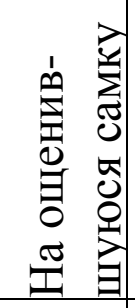 & & & 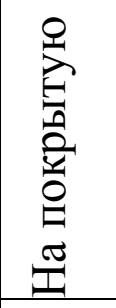 & 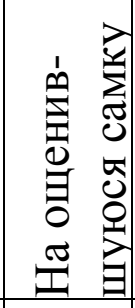 & & & 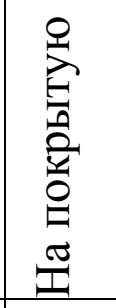 & 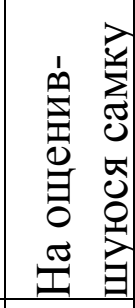 & & 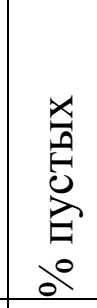 & 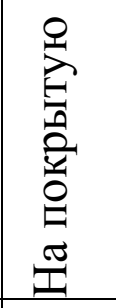 & 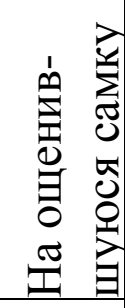 \\
\hline 38 & 28,9 & 3,37 & 4,92 & 33 & 24,2 & 4,42 & 5,84 & 32 & 9,3 & 5,22 & 5,76 & 71 & 26,7 & 3,86 & 5,27 & 32 & 9,3 & 5,22 & 5,76 \\
\hline
\end{tabular}


Как видно из таблицы 64 во второй год жизни самцы покрывают больше самок и дают больше приплода, чем первый год жизни. Это объясняется тем, что самцы норок во второй год жизни становятся наиболее зрелыми и опытными, чем в первый год.

Из таблицы 65 видно, что у двухлетних самок процент пропустовавших самок уменьшается более чем в два раза, отсюда больше выход щенят на покрытую самку.

В 1960 году однолетние самки норок, родившие в колхозе дали большее количество щенят на родившую самку, нежели двухлетние самки. Можно предположить, что родившиеся в местных условиях самки норок хорошо акклиматизировались и их плодовитость не уменьшилась.

Самки за два года были покрыты все. Однако в наличии большой процент пропустования. Так в 1959 г. пропустовало из 38 самок 11 или 29,8 \%; в 1960 г. из 65 самок пропустовало 11 самок или 16,92 \%. В 1959 году повторное покрытие самок проводили после первого покрытия на седьмой день, большинство самок покрыты 2-3 раза, а в 1960 году самок покрыли 2-3 дня подряд и перекрыли на седьмой день. В результате пропустование самок в 1960 году значительно уменьшено.

Таблица 66

Срок беременности и выход щенят

\begin{tabular}{|l|l|l|l|}
\hline $\begin{array}{l}\text { Продолжительность } \\
\text { беременности в } \\
\text { днях }\end{array}$ & $\begin{array}{l}\text { Количество } \\
\text { беременных } \\
\text { самок }\end{array}$ & $\begin{array}{l}\text { Получено } \\
\text { щенят }\end{array}$ & $\begin{array}{l}\text { Получено } \\
\text { щенят на одну } \\
\text { самку }\end{array}$ \\
\hline От 35 до 40 & 5 & 29 & 5,8 \\
От 41 до 45 & 21 & 115 & 5,8 \\
От 46 до 50 & 33 & 180 & 5,45 \\
От 51 до 55 & 10 & 47 & 4,7 \\
От 56 до 60 & 10 & 62 & 6,2 \\
От 61 до 68 & 3 & 13 & 4,3 \\
\hline Всего & 82 & 446 & 5,4 \\
\hline
\end{tabular}

По нашему мнению основные причины пропустования следующие: большинство самок пропустовало в результате слишком раннего покрытия 
до 4 марта; несоблюдение режима кормления в период подготовки к гону и во время гона.

Период беременности у норок колеблется в больших пределах от 35 до 68 дней (разница в 33 дня).

У основного числа норок период беременности, как видно из таблицы 6, колеблется от 46 до 50 дней, с удлинением срока беременности выход щенят уменьшался. У норок, покрытых в первых числах марта период беременности был более длинный, чем у покрытых в конце марта.

Щенение норок проходило без особых осложнений, начиналось оно в 1959-1960 гг. с 1 мая и в основном оканчивалось к 25 мая.

Если в декабре, январе холода стояли до 55-60 градусов Цельсия ниже нуля с короткими днями и норки из клеток не выходили, то с середины февраля (снижение морозов до 25-30²), когда световой день становится длиннее зверьки значительную часть времени дня уже проводили не в домике, а в сетчатой клетке (вольере). И это способствовало тому, что гон проходил очень интенсивно, т.е. суровый климат Якутии как на гон так и на беременность отрицательно не сказывается.

Массовое щенение как в 1959г. так и в 1960 г. проходило с 3 мая по 13 мая, т.е. на 10 дней. В это время щенилось 74 \% учтенных самок. Регистрацию щенят проводили в день щенения. От многопометных самок часть щенят подкладывали к другой малопометной самке. Подложенных щенят мать - кормилица хорошо принимает. В колхозе случаев мертворожденных щенят за 2 года не наблюдалось. Щенята рождались нормальными, взвешивания щенят в день рождения проводить не пытались. Щенята лежали кучами. Это доказывает, что они были здоровы.

Во время щенения каждые 1-2 дня чистили клетки; загрязненную мокрую подстилку в гнездах сменяли новой сухой подстилкой. Однако, в период щенения не удавалось выполнять это требование полностью. Причиной тому были перебои с подстилкой и боязнь зверовода беспокоить 
норчат в первые дни жизни. Бывали случаи, когда в гнездах подстилка не заменялась, а их (гнезда) не чистили по 4-5 дней. В результате в майские и июньские жаркие дни остатки корма, мочи, загнивали внутри клетки, а самки и норчата намокали. Все это явилось частичной причиной гибели щенят в первый месяц жизни. Продукты гниения корма, мочи и кала действовали отравляюще на молодой организм. В середине мая в условиях Якутии становится довольно тепло, к этому времени мы из домиков вынули гнездо, это способствовало предотвращению отхода щенят от повышенной влажности и тепловых ударов.

При излишней влажности и повышении температуры внутри гнезда аппетит норок понижался. Это приводило к снижению молочности самок.

Таблица 67

Анализ падежа щенят норок в 1959 и 1960 гг.

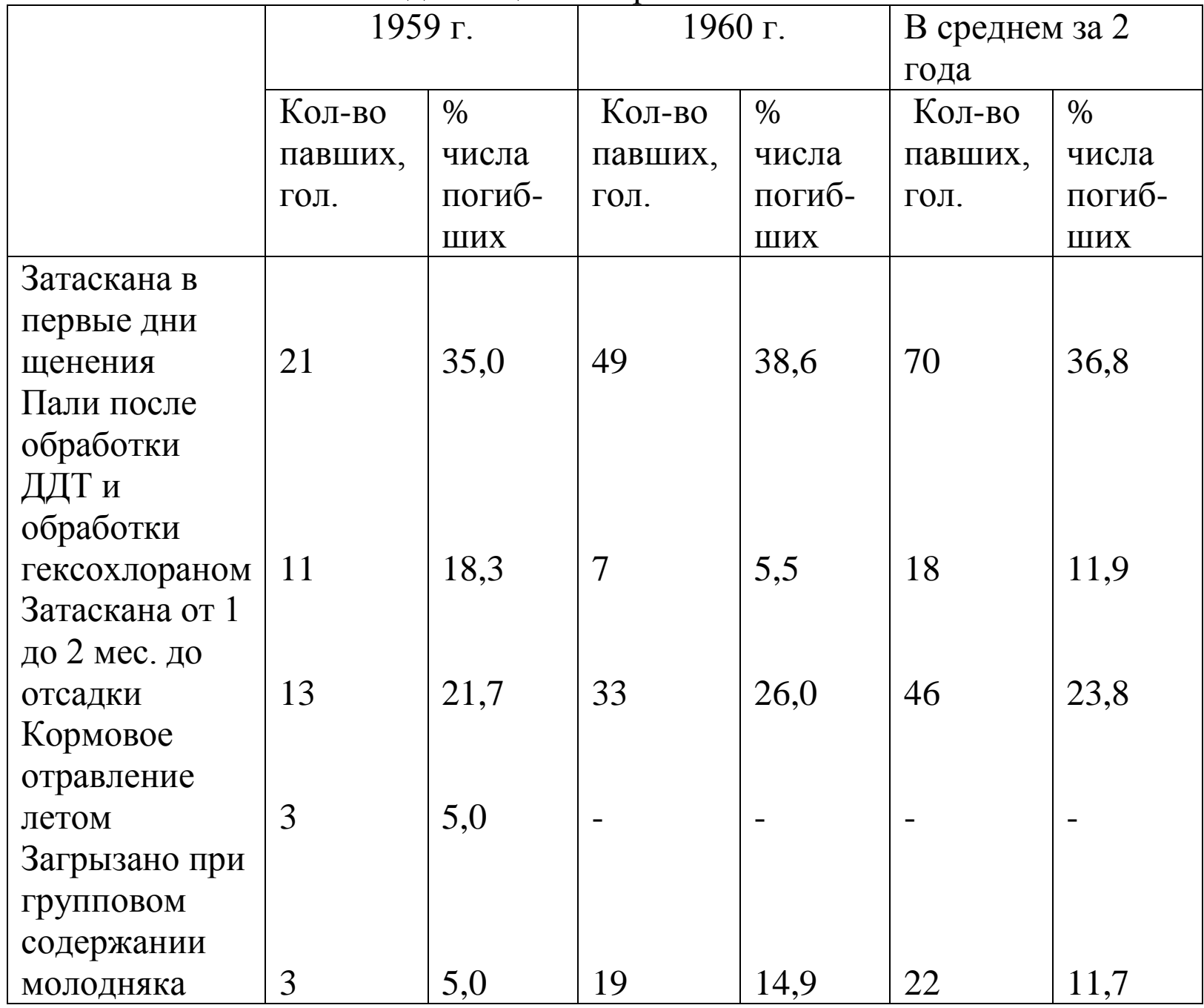




\begin{tabular}{|l|l|l|l|l|l|l|}
\hline $\begin{array}{l}\text { Пастереллез } \\
\text { Прочие } \\
\text { причины }\end{array}$ & - & - & 4 & 3,1 & 4 & 3,3 \\
\hline Всего & 60 & 100,0 & 127 & 100,0 & 187 & 100,0 \\
\hline
\end{tabular}

В 1959 году из родившихся 128 щенят выращено только 68, а в 1960 г. из 305 учтенных выращено до забоя 178 щенят или процент сохранения щенят составило 53,1 \% и 58,4 \% (соответственно). В 1959 и 1960 гг. на штатную самку норок выращено до забоя соответственно 1,83 и 2,78 щенят (таблица 67).

Низкий выход щенят на штатную самку объяснялся большим процентом пропустования самок (в 1959 г. пропустовало 29 \%, а в 1960 г. $15 \%$ самок) и гибели щенят в ранние сроки жизни (в 1959 г. - 46,9\%, в 1960 г. $-41,6 \%)$.

Как видно из таблицы 67, случаи затаскивания молодняка самками и гибель его в первые 3 дня жизни составили, в среднем за 2 года от общего числа погибших 62,6 \%. Этот отход объясняется чрезмерной жарой и влажностью внутри гнезд, а также мало молочностью многоплодных самок, обусловленной недостаточностью кормления, т.к. около1/3 кормов проваливалось через сетку.

В связи с отсутствием необходимого количества домиков и клеток, отъем щенят был проведен в 2-х месячном возрасте, в то время когда щенят от многопометных и маломолочных самок необходимо отсаживать с $35 . .40$ дневного возраста, а прочих не позже 45 дней.

По той же причине недостатка клеток отсаженный молодняк содержали по 2-3 и более щенков в одной клетке. Все эти организационные неполадки привели к гибели молодняка после отсадки (за счет загрызения), ухудшению роста и развития его и снижению качества пушнины.

Норки в жаркую погоду и под прямыми солнечными лучами чувствовали себя угнетенно. В июле и августе когда температура свыше 
$25^{\circ} \mathrm{C}$ норки чувствуют себя плохо. В эти месяцы, в 1959 году, когда не было шеда (навеса), клетки затеняли фанерой, ветками, а также старыми кулями. В тени норки чувствовали себя лучше. Норки очень боятся сырости. В дождливый день в 1959 году домики и клетки также закрывали досками, фанерой. В сараях - шедах намокания домиков от дождя не было. Летом норок обеспечивали доброкачественной водой, поили их в день 3 раза, более редкий водопой быстро ослаблял их организм. Зимой вместо воды давали снег. 
Результаты взвешивания молодняка норок

\begin{tabular}{|l|l|l|l|l|l|l|l|}
\hline \multirow{2}{*}{$\begin{array}{l}\text { Дата } \\
\text { взвеши- } \\
\text { вания }\end{array}$} & $\begin{array}{l}\text { Средний } \\
\text { возраст в } \\
\text { днях }\end{array}$ & \begin{tabular}{l} 
Самки \\
\cline { 3 - 7 } \\
Коли-
\end{tabular} & $\begin{array}{l}\text { Средняя } \\
\text { живая } \\
\text { масса в } \\
\text { граммах }\end{array}$ & $\begin{array}{l}\text { Колебания } \\
\text { в граммах }\end{array}$ & $\begin{array}{l}\text { Коли- } \\
\text { чество }\end{array}$ & $\begin{array}{l}\text { Средняя } \\
\text { живая } \\
\text { масса в } \\
\text { граммах }\end{array}$ & $\begin{array}{l}\text { Колебания } \\
\text { в граммах }\end{array}$ \\
\hline 13/VIII & 90 & 25 & 506.2 & $404-632$ & 15 & 614.4 & $466-718$ \\
23/VIII & 100 & 25 & 555 & $474-756$ & 15 & 665 & $520-990$ \\
3/IX & 110 & 25 & 572 & $448-706$ & 15 & 724 & $576-968$ \\
13/IX & 120 & 24 & 594.5 & $486-718$ & 13 & 722 & $604-896$ \\
23/IX & 130 & 24 & 607.1 & $510-684$ & 13 & 739.2 & $614-896$ \\
3/IX & 140 & 24 & 623.3 & $542-738$ & 13 & 803.4 & $666-1010$ \\
13/IX & 150 & 24 & 707.1 & $578-852$ & 13 & 895.4 & $740-1136$ \\
23/X & 160 & 24 & 734.4 & $592-878$ & 13 & 920.8 & $732-1158$ \\
3/XI & 170 & 24 & 724.6 & $558-902$ & 13 & 1009.2 & $836-1255$ \\
16/XII & 220 & 31 & 637.1 & $480-740$ & 6 & 997.5 & $890-1105$ \\
\hline
\end{tabular}

Таблица 68 
Результаты взвешивания норчат показывают, что с 23 октября, т.е. с наступлением холодов и усиленного образования зимнего опушения, рост тела норок замедляется, почти останавливается. Норкам в это время скармливали доброкачественные корма по поедаемости. Видимо, так же сказываются якутские морозы, к которым норки еще не были приспособлены. Отсюда резкое замедление в увеличении живого веса с 23 октября (таблица 68).

Как выше отмечено, что в период зимних холодов, в декабре январе, норки очень редко выходят из домиков и корма быстро промерзают и в это время норки поедают корма мало, что так же не могло не сказаться на снижении их массы.

Из приведенной таблицы видно, что внутри одного пола у норок одного и того же возраста отмечается большая разница в живом весе. Мелкие особи отстают в живой массе от крупных на 26,6...36 \%. Этот процент отставания в живой массе от крупных довольно высок. Особенно мелкие норчата рождались от мелких зверьков, здесь видимо сказывалась наследственность. Однако в отдельных пометах отставание щенят в росте произошло вследствии маломолочности самок и отсутствия своевременной подкормки щенят. 
Таблица 69

Динамика роста норчат

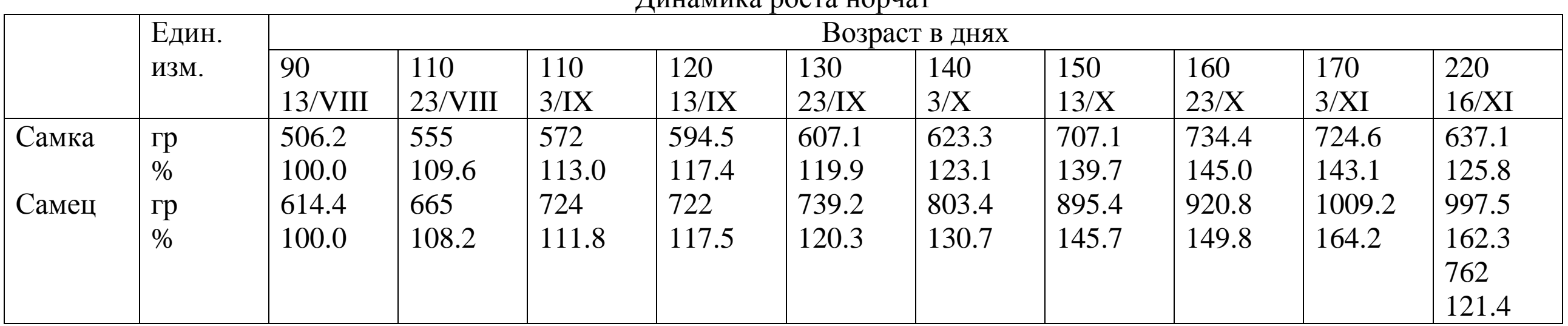


В условиях Якутии трехмесячные щенки норок отстают от щенков такого же возраста, содержавшихся в условиях умеренного климата, на 121,8 грамма. С наступлением прохладной погоды, т.е. со второй половины августа по 23 октября интенсивность роста щенков норок в сравнении с литературным данными в условиях Якутии оказались выше. Вместе с тем с наступлением холодов (с 23 ноября) интенсивность их роста опять значительно замедляется, и даже у них снижается первоначальная максимальная живая масса.

Таблица 70

Результаты бонитировки молодняка норок рождения 1959 и 1960 гг.

\begin{tabular}{|c|c|c|c|c|c|c|c|c|}
\hline \multirow[b]{2}{*}{ годы } & \multirow{2}{*}{$\begin{array}{c}\text { Едини- } \\
\text { ница } \\
\text { изм. }\end{array}$} & \multicolumn{3}{|c|}{ Цвет меха } & \multicolumn{4}{|c|}{ Длина туловища, см } \\
\hline & & $\begin{array}{l}\text { Темно- } \\
\text { корич. }\end{array}$ & $\begin{array}{l}\text { Корич- } \\
\text { невый }\end{array}$ & $\begin{array}{l}\text { Светл. } \\
\text { корич. }\end{array}$ & $\begin{array}{l}\text { От } 38 \\
\text { до } 42\end{array}$ & \multicolumn{2}{|c|}{$\begin{array}{l}\text { От } 35 \\
\text { до } 37\end{array}$} & $\begin{array}{l}\text { От } 22 \\
\text { до } 34\end{array}$ \\
\hline 1959 & $\begin{array}{c}\text { гол } \\
\%\end{array}$ & $\begin{array}{c}55 \\
83,34\end{array}$ & $\begin{array}{c}11 \\
16,66 \\
\end{array}$ & - & $\begin{array}{c}8 \\
12,12 \\
\end{array}$ & \multicolumn{2}{|c|}{$\begin{array}{c}31 \\
46.97\end{array}$} & $\begin{array}{c}27 \\
40,91 \\
\end{array}$ \\
\hline 1960 & $\begin{array}{c}\text { гол } \\
\%\end{array}$ & $\begin{array}{c}28 \\
75,68\end{array}$ & $\begin{array}{c}9 \\
24,32\end{array}$ & - & $\begin{array}{c}1 \\
2,7\end{array}$ & \multicolumn{2}{|c|}{$\begin{array}{c}5 \\
13,5 \\
\end{array}$} & $\begin{array}{c}31 \\
83,8\end{array}$ \\
\hline \multirow{2}{*}{\multicolumn{3}{|c|}{$\begin{array}{l}\text { ица } \\
\text { вения }\end{array}$}} & \multicolumn{6}{|c|}{ Масса самцов, Г } \\
\hline & & & \multicolumn{2}{|c|}{$\begin{array}{l}\text { От } 900 \text { до } \\
1090\end{array}$} & $\begin{array}{l}700 \text { до } \\
0\end{array}$ & \multicolumn{3}{|c|}{\begin{tabular}{|l} 
От 50 до \\
650
\end{tabular}} \\
\hline 1959 & \multicolumn{2}{|c|}{$\begin{array}{c}\text { гол } \\
\%\end{array}$} & \multicolumn{2}{|c|}{$\begin{array}{l}6 \\
20,0\end{array}$} & 33 & \multicolumn{3}{|c|}{$\begin{array}{l}8 \\
26,67\end{array}$} \\
\hline 1960 & \multicolumn{2}{|c|}{$\begin{array}{l}\text { гол } \\
\%\end{array}$} & \multicolumn{2}{|l|}{$\begin{array}{l}6 \\
100,0\end{array}$} & & \multicolumn{3}{|c|}{-} \\
\hline \multicolumn{4}{|c|}{ Качество опушения } & \multicolumn{5}{|c|}{ Масса самок, Г } \\
\hline отлично & \multicolumn{2}{|c|}{ хорошо } & тосред. & $\begin{array}{l}\text { От } 700 \text { до } \\
800\end{array}$ & $\begin{array}{l}\text { От } 55 \\
700\end{array}$ & & \multicolumn{2}{|c|}{$\begin{array}{l}\text { От } 400 \text { до } \\
550\end{array}$} \\
\hline $\begin{array}{l}61 \\
92,42\end{array}$ & \multicolumn{2}{|l|}{$\begin{array}{l}34 \\
6,55\end{array}$} & 03 & $\begin{array}{l}9 \\
25,0\end{array}$ & $\begin{array}{l}21 \\
58,34\end{array}$ & & \multicolumn{2}{|c|}{$\begin{array}{l}6 \\
16,66\end{array}$} \\
\hline $\begin{array}{l}37 \\
100,0\end{array}$ & \multicolumn{2}{|l|}{-} & 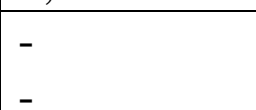 & $\begin{array}{l}5 \\
16,1\end{array}$ & $\begin{array}{l}25 \\
80,6\end{array}$ & & \multicolumn{2}{|c|}{$\begin{array}{l}11 \\
3.3\end{array}$} \\
\hline
\end{tabular}

Средняя живая масса одной самки составила 637, 1 гр., самца - 997,5 гр. Длина туловища соответственно составила 31,1 и $36,3 \mathrm{~cm}$. Как видно из этой таблицы, что длина туловища стала заметно короче в 1960 г, а живая масса по сравнению с 1959 г. не уменьшилась, а наоборот имело место некоторое увеличение. По сравнению с 1959 г. в 1960 году качество 
опушения значительно улучшилось. Улучшение качества опушения, видимо, объясняется климатическими условиями.

В отличие от зон средней полосы, с умеренным климатом, где норок кормят 1-2 раза, в Якутии в силу суровости зимы в зимнее время установили трехразовое кормление. Это вызвано тем, что при двукратном кормлении норки недоедали - не съедали положенной им нормы корма, т.к. он замерзал.

Зимой в ноябре-феврале, а так же в период беременности, лактации и первый месяц после отсадки щенятам дают трехразовое кормление, а остальное время - двухразовое.

В период гона подготовку корма и скармливание проводили с 4 часов дня до 6 часов вечера, а с 9 часов утра до 11 часов и с 2 часов до 4 часов проводили соединение пар.

Бонитировку норок проводили двукратно летом и зимой. Летнюю бонитировку молодняка норок проводили в 2-х-3-х месячном возрасте. При этом основное внимание уделяли качеству родителей - а у молодняка, размеру тела, живому весу, окраске туловища. Старались отобрать лучший молодняк от лучших родителей.

Зимнюю бонитировку провели в конце ноября. Здесь основное внимание уделяли: окраске и размеру туловища, живому весу, а также качеству опушения.

Забой норок проводился в конце ноября и в первой половине декабря месяца. Стоимость одной шкурки в 1959 году была 317 рублей, а в 1960 г. составила в среднем 284 р. 70 коп. Зачет шкурок составил в 1959 г. - 78,3 \%, а в 1960 г. - только 70,3\%.

Группировка сданных шкурок по цвету, размеру и дефектности в результате сдачи в 1960 году, приведена в таблице 71. 
Таблица 71

Анализ качества норочьей пушнины колхоза им. Ленина Мегино-

\begin{tabular}{|c|c|c|c|c|c|}
\hline \multicolumn{6}{|c|}{ Кангаласского р-на } \\
\hline \multicolumn{3}{|l|}{ По цвету } & \multicolumn{3}{|l|}{ По размеру } \\
\hline цвет & Кол-во & $\%$ & размер & Кол-во & $\%$ \\
\hline $\begin{array}{l}\text { Черный и } \\
\text { т/корич. }\end{array}$ & 59 & 48,0 & Крупный & 19 & 15,4 \\
\hline Коричневый & 46 & 37,4 & Средний & 74 & 60,2 \\
\hline $\begin{array}{l}\text { Светло- } \\
\text { коричневый }\end{array}$ & 18 & 14,6 & мелкий & 30 & 24,4 \\
\hline Итого & 123 & 100,0 & & 123 & 100,0 \\
\hline \multicolumn{3}{|c|}{ По дефектности } & \multicolumn{3}{|c|}{ По качеству опушения } \\
\hline дефектность & Кол-во & $\%$ & $\begin{array}{l}\text { Качество } \\
\text { опушения }\end{array}$ & Кол-во & $\%$ \\
\hline Норм. & 69 & 56,1 & $\begin{array}{l}\text { Отличное и } \\
\text { хорошее }\end{array}$ & 95 & 77,3 \\
\hline М/деф. & 41 & 33,3 & Удовлетвори- & 21 & 17,1 \\
\hline С/деф. & 10 & 8,1 & тельное & & \\
\hline Б/деф. & 3 & 2,5 & плохое & 7 & 5,6 \\
\hline Итого & 123 & 100,0 & & 123 & 100,0 \\
\hline
\end{tabular}

Таблица 72

Зависимость стоимости цены шкурок норок от размера, качества цвета меха и от дефектности шкурок

\begin{tabular}{|l|l|l|l|}
\hline \multicolumn{4}{|l|}{ Темнокоричневые и нормальные шкури } \\
\hline По размерам & $\begin{array}{l}\text { Цена 1 шкурки } \\
\text { (руб.) }\end{array}$ & \% от наивысшего & $\begin{array}{l}\text { Потеря шкурок в } \\
\text { цене в руб. }\end{array}$ \\
\hline Крупные & 405 & 100,0 & - \\
Средние & 355 & 87,6 & 50 \\
Мелкие & 299 & 73,8 & 106 \\
\hline Крупная нормальная шкурка & $\begin{array}{l}\text { Цена 1 шкурки } \\
\text { (руб.) }\end{array}$ & \% от наивысшего & $\begin{array}{l}\text { Потеря шкурок в } \\
\text { цене в руб. }\end{array}$ \\
\hline $\begin{array}{l}\text { По цвету } \\
\text { туловища }\end{array}$ & 405 & - \\
\hline $\begin{array}{l}\text { Черные и } \\
\text { т/коричневые }\end{array}$ & 100,0 & \\
\hline
\end{tabular}




\begin{tabular}{|l|l|l|l|}
\hline $\begin{array}{l}\text { Коричневые } \\
\begin{array}{l}\text { Светло- } \\
\text { коричневые }\end{array}\end{array}$ & 361 & 89,1 & 44 \\
\hline Среднего размера и коричневого цвета & 78,5 & 87 \\
\hline По дефектности & $\begin{array}{l}\text { Цена 1 шкурки } \\
\text { (руб.) }\end{array}$ & \% от наивысшего & $\begin{array}{l}\text { Потеря шкурок в } \\
\text { цене в руб. }\end{array}$ \\
\hline Нормальный & 318 & 100,0 & - \\
М/дефектный & 286 & 90 & 32 \\
С/дефектный & 238 & 74,8 & 80 \\
Б/дефектный & 159 & 50 & 159 \\
\hline
\end{tabular}

Как видно из этой таблицы: при малом размере шкурки стоимость ее снижается на 106 руб. (в сравнении с крупным), при большой дефектности снижение составляет (от нормальных крупных) 159 руб., по цвету туловища от черного к светло-коричневому теряется 87 руб. на шкурку.

Как видно из таблицы 71 в колхозе получено значительное количество дефектных шкурок без дефектных было только 56, 1 \%. Причиной этого послужило то, что в колхозе не сумели организовать хорошее содержание норок, клетки и домики были построены с большим запозданием, построены были не доброкачественно, и сидели в них по 3 по 4 щенка. Отсюда - потертости меха, закусы и другие дефекты снизившие качество пушнины. Кроме этого шкурки были оправлены неправильно, а у звероводов практического опыта в этом деле не было. Снижению качества так же способствовала неудовлетворительная первичная обработка шкурок по мездре и волосу.

Также колхоз терял много денег из-за сдачи в заготовительный пункт шкурок малого размера. Крупные шкурки составляли от общего количества только $15,4 \%$.

Кроме этого необходимо учитывать и то положение, что колхоз увеличивал поголовье норок, поэтому оставлялись на племя не только крупные, но и часть мелких зверей колхоз при этом естественно лучших 
особей оставлял на племя, на шкурки шли только мелкие звери отсюда и низкая цена шкурок норок в 1960 г.

Таблица 73

Половозрастное поголовье норок колхоза на 1 января 1960 г.

\begin{tabular}{|l|l|l|l|l|l|l|l|l|l|l|}
\hline \multicolumn{2}{|l|}{ Рождения 1958 г. } & \multicolumn{2}{l|}{ Рождения 1959 г. } & \multicolumn{2}{l|}{ Рождения 1960 г. } & \multicolumn{2}{|l|}{ Всего норок } \\
\hline $\begin{array}{l}\text { Сам- } \\
\text { цы }\end{array}$ & $\begin{array}{l}\text { Сам- } \\
\text { ки }\end{array}$ & $\begin{array}{l}\text { всего } \\
\text { вам- }\end{array}$ & $\begin{array}{l}\text { Сам- } \\
\text { ки }\end{array}$ & $\begin{array}{l}\% \\
\text { всего }\end{array}$ & $\begin{array}{l}\text { Сам- } \\
\text { цы }\end{array}$ & $\begin{array}{l}\text { Сам- } \\
\text { ки }\end{array}$ & $\begin{array}{l}\% \\
\text { всего }\end{array}$ & $\begin{array}{l}\text { Сам- } \\
\text { цы }\end{array}$ & $\begin{array}{l}\text { Сам- } \\
\text { ки }\end{array}$ \\
\hline 5 & 40 & 40,5 & 8 & 7 & 13,5 & 5 & 46 & 46,0 & 18 & 93 \\
\hline
\end{tabular}

При правильной структуре стада процент однолетних норок должен составить не более 20-25 \%. Колхоз планировал довести поголовье норок к концу 1965 года до 500 голов, в том числе 400 самок и 100 самцов.

Норководство в Покровской звероферме. Годовой опыт норководства колхоза им.Ленина Мегино-Кангаласского района позволил Якутскому потребительскому союзу «Холбос» в ноябре 1959 года завезти норок из подмосковного совхоза на Покровскую звероферму. На 1 января 1960 г. на звероферме было 117 норок, в том числе самок 92, самцов 25.

Вначале «Холбос» предполагал отправить норок в Кобяйский район в Ниджилинскую звероферму, но последний к приему норок был не подготовлен. Поэтому Покровская звероферма вынуждена была принять завезенное поголовье будучи так же неподготовленным. Разместили их в наспех построенные клетки произвольной конструкции и домики (без гнезда) размером 20х20х20. Так и содержали норок в зимнее время 19591960 гг. В результате содержания зверей в неутепленных домиках без гнезд наблюдались случаи падежа норок от замерзания.

Гон норок начался с 1 марта месяца. В большинстве случаев норок покрывали один-два раза. Очень редко норок покрывали 3-4 раза. Повторное покрытие проводили через 7 дней после первого покрытия. 
Таблица 74

Зависимость результатов щенения в зависимости от покрытия

\begin{tabular}{|l|l|l|l|l|}
\hline $\begin{array}{l}\text { Количество } \\
\text { покрытий }\end{array}$ & $\begin{array}{l}\text { Покрыто } \\
\text { всего }\end{array}$ & $\begin{array}{l}\text { Из них } \\
\text { ощенилось }\end{array}$ & пропустовало & $\begin{array}{l}\text { \% } \\
\text { пропустования }\end{array}$ \\
\hline Однократное & 5 & 1 & 4 & 80,0 \\
Двукратное & 57 & 45 & 12 & 21,0 \\
Трехкратное & 19 & 14 & 5 & 26,3 \\
Четырехкратное & 3 & 3 & - & - \\
Пятикратное & 1 & 1 & - & - \\
\hline & 85 & 64 & 21 & 24,7 \\
\hline
\end{tabular}

С увеличением количества покрытий уменьшается количество пропустовавших самок.

Щенение проходило с 30 апреля по 25 мая.

.Таблица 75

Группировка самок по количеству щенят

\begin{tabular}{|c|c|c|c|c|c|c|c|c|c|c|c|}
\hline 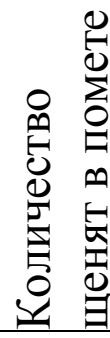 & 1 & 2 & 3 & 4 & 5 & 6 & 7 & 8 & 9 & 12 & Всего \\
\hline 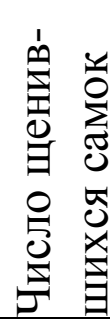 & 3 & 4 & 4 & 8 & 15 & 15 & 6 & 6 & 2 & 1 & 64 \\
\hline$\%$ & 4,69 & 6,25 & 6,25 & 12,5 & 23,43 & 23,43 & 9,37 & 9,37 & 3,12 & 1,56 & 100,0 \\
\hline
\end{tabular}

Основная масса норок (47 \%) дала 5-6 щенят. Благополучно ощенившие самки норок дали 335 щенят, т.е. на ощенившую самку в среднем - 5,23 щенка, а на покрытую - 3,94 щенка.

Кроме этого до регистрации заморозили или съели своих щенят 12 
самок. Зарегистрировано мертворожденных 24 щенка. Отход щенят молодняка из числа зарегистрированных составил 54 головы или 16,1%.

На одну штатную самку было выращено 3,3 щенка.

Таблица 76

Причины отхода щенят

\begin{tabular}{|l|l|l|}
\hline Причины отхода щенят & Кол-во & $\begin{array}{l}\text { \% от числа } \\
\text { потерянных }\end{array}$ \\
\hline Съедено, затаскано при совместном & & \\
содержании & 22 & 40,7 \\
Во время дождя от простудных заболеваний & 5 & 9,2 \\
Сбежало в тайгу & 11 & 20,5 \\
Пали от теплового удара & 7 & 13,0 \\
Съедено лисицей & 1 & 1,8 \\
Утонуло в воде & 1 & 1,8 \\
Пали от неизвестных причин & 7 & 13,0 \\
\hline Итого & 54 & 100,0 \\
\hline
\end{tabular}

Падеж щенят происходил из-за неудовлетворительного ухода за зверями, жарких условий содержания летом и того, что отсаженных щенков содержали группами вследствие недостатка клеток.

При лучшем уходе, содержании и обеспечении клетками звероферма смогла бы сократить падеж щенят.

В отличие от колхоза им.Ленина, где кормление было однообразное мясное, без овощей и с применением добавок (таблица 62) кормление норок в Покровской звероферме проводилось разнообразными кормами, в основном, по поедаемости и в большом количестве использовали свежедробленую кость, овощи, витаминные добавки. Из мясных кормов большой удельный вес занимали требуха, кровь. Взамен части мяса почти в течение всего года давали творог. Такое кормление не могло не сказаться на плодовитость самок. Дача кормов в виде гомогенной смеси фарша способствовало лучшей поедаемости и более высокому \% усвояемости. Дробленые корма зверям легче съесть и почти невозможно растаскивать, заносить их в домики и гнезда поэтому на норковой ферме не наблюдалось гниения остатков кормов внутри домика. 
Своевременное удаление (в середине мая) гнезд из домиков привело к обеспечению оптимальной температуры внутри них, что способствовало лучшим зоогигиеническим условиям жизни. В колхозе им.Ленина вытаскивание гнезд из домиков было сделано только в июне. Это приводило к перегреву щенков в утепленных гнездах, тепловым ударам и их гибели.

На звероферме все корма завозные, это (списанные консервы и т.п. Якутторга, Холбоса, отходы Якутской бойни, Якутского молокозавода, рыбзавода и Покровского пищекомбината. Стоимость купленного мяса составила от 4 руб. 20 коп. до 10 руб. за 1 килограмм; требухи - 1 руб. 24 коп. до 1 руб. 50 коп.; творога - от 1 руб. 84 коп. до 3 руб. 50 коп. за 1 килограмм.

В 1960г. звероферма сдала шкурок 143 шт. на сумму 44588 руб., средняя сдаточная цена шкурки составила 314 руб., кроме этого 88 норок продали по 405 рублей совхозу Октемский и республиканской станции юннатов. От сдачи шкурок норок и от продажи норок совхоз получил 80228 руб. дохода.

По данным бухгалтерского учета зверофермы за год скормлено норкам кормов на 71738 руб. (в деньгах 1960 г.). В декабре 1960 г. звероферма дополнительно завезла из Забайкальского зверосовхоза 50 норок, в том числе 40 самок, 10 самцов и производственное стадо норок составило 184 норки. Все поголовье норок обслуживало двое работниц. Кормление норок двухразовое, зимой норок совершенно не поили и снега не давали. На кормлении норок затрачивали 20-30 минут. В 1960 году на звероферме Покровска скормлено следующее количество кормов (кг). 
Таблица 77

Расход кормов, скормленных в 1960г, кг

\begin{tabular}{|c|c|c|c|c|c|c|c|c|c|c|c|c|c|}
\hline Наименование кормов & I & II & III & IV & $\mathrm{V}$ & VI & VII & VIII & IX & $\mathrm{X}$ & XI & XII & $\begin{array}{l}\text { Всего за } \\
\text { год }\end{array}$ \\
\hline \multicolumn{14}{|l|}{ 1. Мясные корма } \\
\hline Мясо лося & 76,0 & - & - & 172 & 130 & - & - & - & - & - & - & - & 378 \\
\hline Мясо скотское, конина & 150 & 223,8 & 286,2 & - & 126 & 517 & 550 & 824,3 & 926 & 577 & 295 & 111,0 & 4586,3 \\
\hline Язык & - & 14,6 & - & - & - & - & - & 2,5 & - & & & & 17,1 \\
\hline Требуха & 293,5 & 286,7 & 154,5 & 30 & 133 & 137 & 416 & 903,8 & 1011 & 1298,8 & 1135 & 144,6 & 5944 \\
\hline Печень & 66 & 60,9 & 59,5 & 60 & 20 & - & 170,6 & - & - & - & & - & 437 \\
\hline Кровь & 63 & 62 & 70 & 75 & 77,5 & 116,5 & 132 & - & 80 & 40 & 258,5 & 48 & 1022,5 \\
\hline Рыба & - & - & 110 & 153 & 25 & 25 & 508 & 619 & & - & & - & 1415 \\
\hline Голова & - & - & - & - & - & - & - & - & 211,5 & - & 940,5 & 66 & 1218 \\
\hline Мясо ондатры & - & - & - & 41 & - & - & - & - & - & - & - & - & 41 \\
\hline \multicolumn{14}{|l|}{ 2. Молочные корма } \\
\hline Творог обезжиренный & 78 & 62 & 62 & 75 & 77,5 & 116,5 & 733 & 327 & 503 & 384,8 & 129,8 & 7,8 & 2556,4 \\
\hline Молоко цельное & - & 8 & 52 & 60 & 70 & - & 27 & 150,4 & - & 89,6 & - & - & 457 \\
\hline \multicolumn{14}{|l|}{ 3. Зерновые культуры } \\
\hline Отруби, комбикорм & 36 & 33 & 30 & 15,4 & 19 & 39,3 & 24,8 & 16 & 4 & - & - & 21 & 238,5 \\
\hline Крупа овсяная & 36 & 33 & 31 & 30 & 29,4 & 43 & 25 & 86,2 & 20,3 & 116,2 & 138,1 & 23,4 & 794,3 \\
\hline Мука & - & - & 8 & 16 & 12 & 24 & 29 & 20 & 15 & 15 & 15 & - & 154 \\
\hline Крупа ячменная & - & - & - & - & - & - & 63,2 & 16 & - & - & - & - & 79,2 \\
\hline Крупа рисовая & - & - & - & - & - & - & - & 21 & - & - & - & - & 21 \\
\hline \multicolumn{14}{|l|}{ 4. Овощные } \\
\hline Капустные листья & 36 & 33 & 25 & 25 & - & - & - & - & - & 38 & - & - & 157 \\
\hline Морковь & 36 & 24 & - & - & - & - & - & 87,2 & 122 & 58,2 & 149,8 & 23,4 & 500 \\
\hline Турнепс & - & 4 & 26 & - & - & - & - & - & - & - & - & - & 30 \\
\hline Картофель & - & - & 4 & 12 & 8 & 12 & 4 & - & 5 & 15 & - & - & 60 \\
\hline Помидоры & - & - & - & 18 & 17,5 & - & - & - & - & - & - & 66 & \\
\hline Баклажаны & - & - & - & - & 24 & 100 & - & - & - & - & - & - & 124 \\
\hline Зелень & - & - & - & - & - & - & - & - & 77 & - & - & - & 77 \\
\hline Шиповник & - & 1,0 & - & - & - & - & - & - & - & - & - & - & 1,0 \\
\hline \multicolumn{14}{|l|}{ 5. Витаминные корма } \\
\hline Рыбий жир & 0,6 & - & 1,6 & 2,0 & 2,0 & - & - & - & - & - & - & - & 5,6 \\
\hline Дрожжи сухие & 0,6 & - & 0,8 & 1,6 & 1,2 & 1,6 & 1,6 & 1,0 & 1,0 & 1,0 & - & 4,8 & 14,2 \\
\hline Хмель & - & - & - & - & - & 0,2 & 0,5 & 0,5 & 0,3 & 1,3 & - & - & 2,8 \\
\hline Соль & 3,0 & 2,9 & 3,1 & 0,5 & 0,3 & 3,4 & 10,4 & 10,0 & 9,5 & 5,0 & 6,2 & 1,0 & 56,2 \\
\hline
\end{tabular}


Краткие итоги первых опытов норководства в Якутии. В Якутии в 60-е годы XX века многие колхозы зверей содержали на одних мясных кормах, полученных от павших и вынужденно забитых животных. Если не было бы звероводства все эти отходы в большинстве случаев в то время были бы выброшены. Следовательно, скармливая все это пушным зверям колхозы и совхозы превращали отходы в ценную пушнину, в денежные доходы.

На зверофермы от овощеводства поступали капустный лист, испорченный картофель и морковь. Все это оценивалось независимо от качества и степени испорченности, как доброкачественный корм по себестоимости этих продуктов или по средней проданной на рынке цене. Что приводило к тому, что в колхозах и совхозах искусственно увеличивалась себестоимость выращивания пушных зверей.

По итогам 1959 г. в колхозе им.Ленина Мегино-Кангаласского района себестоимость выращивания норок 353 руб. 40 коп. Расход всего составил в 26478 руб. 77 коп., причем из этой суммы на кормлении затрачено 17797 руб. 77 коп. или от общей затраты на кормление составили 67,2 \%.

Выводы - несмотря не вполне удачные работы по норководству ввиду отсутствия опыта, неполадок организационного периода в первые годы существования и низкого делового выхода разведение норок себя оправдывало. При увеличении делового выхода щенят норок и повышении качества первичной обработки шкурок, с увеличением поголовья норок и установлением рационального кормления при отсутствии искусственного завышения стоимости кормов себестоимость норководства можно было понизить на 40-50 $\%$ и норководство превратилось бы в рентабельную отрасль звероводства (Веселов В.И., Заболоцкий И.П., 1964). 


\section{5. Перспективы норководства в Республике Саха (Якутия)}

Благоприятные климатические условия для разведения норок в условиях Республики Саха (Якутия), что было доказано еще в 60-е годы и большой спрос на шкурки норок, при ограниченной потребности населения в пушнине серебристо-черных лисиц и голубых песцов, способствует дальнейшему развитию норководства. В пользу развития норководства в нашей республике говорит и тот факт, что потребление кормов норками в 3 раза меньше, чем лисицами и песцами. Что особо актуально при нынешней проблематичности кормовой базы всего животноводства и звероводства, в частности. Следует отметить, что при дефиците мясных кормов основным кормом при кормлении норок в условиях РС (Я) должны быть рыбные корма.

Коллективные хозяйства нашей республики располагают большими возможностями заготовки мелкочастиковой рыбы и отходов оленеводства. Это дополнительный резерв животных кормов для звероводства. Что, к сожалению, в настоящее время используется далеко недостаточно. Хотя об этой проблеме было сказано на выездном Совещании Правительства РС (Я) в Покровском цехе звероводства ГУП ФАПК «Сахабулт» по проблемам клеточного звероводства в 2003 году.

Витаминная промышленность страны развивается успешно, имеются отличные поливитаминные препараты, но они не имеют должного применения, использования в кормлении пушных зверей Якутии. Отличные примеры положительного влияния витаминных препаратов на пушно-меховые качества, разводимых в неволе пушных зверей не являются секретом. Особенно это актуально при существующем в настоящее время кормлении пушных зверей несбалансированными рационами.

Вторично норка привезена в нашу республику в 2005 году. Молодняк был получен в 2006 году в Усть-Алданском улусе (бригадир заслуженный работник звероводства Сивцев И.П.), деловой выход составил 5 голов на 1 штатную самку. Норководство за короткий срок привлекло внимание многих 
хозяйственников, в том же году молодняк был куплен звероводами Кобяйского и Хангаласского улусов.

К 1 января 2007 г. в республике занимаются разведением норок 3 зверохозяйства.

Разведение стандартной норки в 60-е годы и в 2005-2006 г. доказывает о широкой возможности разведения норок в условиях Центральной Якутии. В условиях Якутии в ближайшее время необходимо разработать экономически выгодные нормы кормления с учетом климатических условий республики. Учитывая резкую перемену климата в условиях Центральной Якутии целесообразно вынимать гнезда из домиков начиная со второй половины мая. Нормы нагрузки на одного норковода устанавливать 80 норок с соответствующим числом самок и самцов и их молодняка. Для подготовки кормов и скармливания необходимо иметь поваров.

Успешный двухлетний опыт разведения стандартных норок в Якутии позволяет приступить и к разведению цветных норок.

Климатические условия Центральной Якутии благоприятно действуют улучшению мехового качества шкурки норок: мех становится густым и пышным.

\section{Глава 4. Перспективы развития охотничьего собаководства} PC (Я).

\section{1. Современное состояние собаководства в Якутии.}

Многие ошибочно считают, что якутская лайка произошла от признанных во всем мире хаски Финляндии и Аляски. Напротив. Прародителями хаски являются наши собаки. Издревле голубоглазые лайки рождались только в Нижнеколымске. Их отличали густая пушистая шерсть, массивный хвост, загибающийся набок, и крупная голова. Наша лайка гораздо костистее и мощнее хаски. Трудно найти другую породу, обладающую столь уравновешенным характером. Эти абсолютно не агрессивные существа легко 
входят в контакт с человеком и охотно играют с детьми. Выносливые бегуны незаменимы на просторах бескрайней тундры.

Якутские лайки прекрасно ориентируются на открытом пространстве и всегда находят правильный путь.

В советские времена, когда северяне пересели на снегоходы, ездовые собаки были отодвинуты на второй план. Сегодня они на грани вымирания.

В таежной части Республики Саха (Якутия) аборигенные лайки с глубокой древности использовались только для охоты, ездовых и оленегонных держали только в тундре. Даже на скальных рисунках видны сюжеты охоты на лося с собаками.

Аборигенные лайки с начала 1970-х годов повсеместно стали ухудшаться, смешиваясь со всевозможными привезенными породами и помесями. Причина, как и везде в Сибири, - вольное содержание. Вывезенные из Якутии лайки для создания заводского типа восточносибирских лаек неплохо зарекомендовали себя. От Пирата (вл. Филиппов Н.Е.), вывезенного в С.-Петербург, был получен Буран (вл. Рясный Н..Л.), имеющий дипломы I ст. по медведю и кабану.

По описанию Гейца, в 1960-е годы якутские лайки отличались крупным ростом и повсеместно применялись на охоте на копытных. С начала 1980-х годов в республику начали интенсивно завозить породных лаек, в особенности западносибирских. Из одного только Новосибирского питомника за короткое время завезли 300 щенков, самое активное участие в этом принимало Республиканское общество охотников. Разводили щенков среди охотниковлюбителей и промысловиков.

В данное время от породных лаек мало что осталось; кроме того, у сельских охотников-промысловиков сложилось негативное мнение о завозных породных лайках.

Аборигенные лайки, имеющие сильные гены здоровых кровей, работали без сильной натаски на первом сезоне, быстро понимали требования хозяина.

В октябре начинается промысловый сезон — охота на соболя. Для такой охоты лучше подходят рослые, крепкого сложения, хорошо одетые, с крепкими 
несдирающимися лапами собаки. У завозных лаек лапы сдираются поразительно быстро, межпальцевая перепонка растрескивается, и собаки выходят из строя. У аборигенных собак были крепкие лапы, как у ездовых собак, почти как у волка. Импульсивные, реактивного нрава собаки при такой охоте быстрее перегорают. Лучше выдерживают собаки крепкой конституции, с более широкой поясницей и животом, чем сухопарые; крепкие, прочные лапы также при всех зимних охотах имеют очень важный плюс.

После сезона охоты на соболя начинается охота на ондатр до середины апреля. Это очень надоедливое для собак занятие, собака зверька не видит, мешают низкие температуры. Большинству собак через пару недель надоедает поиск хаток. Лучше работают послушные собаки, не обращающие внимания на белок и лошадей, так как зимой вокруг озер тебенюют якутские лошади, а белок зимой слышно за полверсты. Для такой охоты лучше подходят аборигенные лайки, вывезенные из близлежащих регионов Эвенкии и Нижней Тунгуски Иркутской области. К счастью, там еще сохранились аборигенные собаки, хотя не в самом лучшем состоянии из-за тесного инбридинга в маленьких деревнях. Также неплохо работают восточники заводского разведения, улучшенные этими аборигенами.

На данное время в Республике Саха (Якутия) не уделяют никакого внимания развитию охотничьего собаководства. В 1992 г. из-за кризиса был ликвидирован питомник восточносибирских лаек при Госагропроме ЯАССР, четыре собаки из этого питомника в 1989 г. в Иркутских состязаниях по белке, медведю и кабану, завоевав 9 дипломов, заняли первое место («Охота и охотничье хозяйство», 1990, N№ 6).

Исходя из всего вышеописанного, следует считать наиболее подходящими для нашего экстремального климата восточносибирских лаек аборигенных кровей. Если не принять срочные меры для сохранения оставшихся местных лаек, лет через 10-15 они безвозвратно исчезнут. Только сохранение в местах обитания местных лаек возродит процветание породы в целом и обеспечит промысловиков Якутии наиболее приспособленными 
лайками. Сохранение аборигенных лаек на местах обитания обеспечит свежей кровью заводских восточников, генофонд которых не так богат. Еще у современных заводских восточников, видимо, преобладает кровь прибайкальских лаек менее выносливого типа, чем лайки вышеупомянутых регионов, где зимой температура почти как у нас, нередко за минус 55 градусов по Цельсию. Собаки, приспособленные к холоду, лучше выдерживают голод, у них выше усвояемость кормов, и они очень выносливы. (Власов Н.Н., Камерницкий А.В., Медведева И.М.,1992; Войлочников А.Т., Войлочникова С.Д., 1974; Мазовер А.П., 1979; Псалмов М.Г., 1990).

\section{2.Советы по разведению лаек.}

Приобретать щенка лучше всего в возрасте тридцати пяти - сорока дней. Родители щенка должны быть полевыми работниками, т. е. иметь выходы на охоту. Это гарантирует, что приобретаемый щенок имеет необходимые охотничьи задатки и при правильном его воспитании, дрессировке и натаске тоже станет хорошим полевым работником.

Щенок должен быть физически здоровым и хорошо упитанным, что определяется его наружным осмотром. Здоровый щенок - подвижным, он имеет блестящий (не тусклый) волосяной покров и не скулит.

Щенок должен иметь хороший аппетит и быть приучен есть корм самостоятельно из мисочки. Это необходимо проверить на месте до взятия щенка.

Щенок не должен иметь явных физических и породных пороков, что также устанавливается его наружным осмотром. При этом обращается внимание на типичность окраса; на глаза (нет ли бельма), на задние лапы (нет ли прибылых пальцев), на прикус зубов (нет ли явно неправильного прикуса), на хвост (нет ли уродства и правильно ли он купирован, если это требуется для породы), на животик (нет ли пупочной грыжи). (Власов Н.Н., Камерницкий А.В., Медведева И.М.,1992; Войлочников А.Т., Войлочникова С.Д., 1974; 
Мазовер А.П., 1979; Псалмов М.Г., 1990).

\section{3. Теоретические предпосылки к разведению лаек.}

Якутские лайки, по мнению Войлочниковых А.Т. и С.Д., обладают многими ценными качествами и, прежде всего удивительной неприхотливостью и отличными охотничьими свойствами. Большинство из них начинают работать без предварительной натаски. На промысле после изнурительной работы им нередко приходится довольствоваться скудным кормом и отдыхать на открытом воздухе при жестоких морозах в долгие зимние ночи. Эти лайки могут вскоре повсеместно исчезнуть, если не будут приняты действенные меры к их сохранению. Необходимо якутских лаек разводить заводскими методами не только в питомниках, но и в промысловоохотничьих хозяйствах, где их разведением должны заниматься охотоведы этих хозяйств. К сожалению, многие охотоведы не уделяют местным лайкам нужного внимания, часто они способствуют их исчезновению, завозя породных восточносибирских лаек в те немногие места, где еще имеются очаги местных лаек. Появление же новой (хотя и близкой) породы в районах с примитивным ведением собаководства неизбежно ведет к метизации и исчезновению как местного, так и завезенного породного типа. В последние годы метисные лайки, происходящие от якутских и породных восточносибирских, встречаются во многих районах РС (Я). Вряд ли это полезно для промыслового собаководства.

Для сохранения якутских лаек необходимо как можно быстрее разработать соответствующую программу работ (выбрать место для организации питомника, провести селекционно-племенные и ветеринарнопрофилактические мероприятия и др.), выделить необходимые средства и, контролируя проведение работ, добиваться намеченных целей. Если такие работы не предпринять в ближайшие годы, будут неизбежно потеряны своеобразные и ценные охотничьи лайки, которых в течение многих веков создавали и совершенствовали народы РС (Я). Якутские лайки заслуживают самого пристального внимания и их необходимо сохранить.

При содержании собаки на дворе для нее строится выгул размером не 
менее 3х3 м, при условии, если он строится изолированно от стены какого-либо помещения и не менее 3 х2 м при его пристройке к стене здания. Чтобы собака в выгуле имела большую свободу для движения, желательно площадь выгула (если есть возможность) увеличить в полтора-два раза. Для устройства выгула используется металлическая оцинкованная сетка, которая натягивается и прибивается к верхним и нижним деревянным брусьям, прикрепленным к деревянным столбикам или металлическим трубам, вкопанным в землю. Чтобы собаки не могли перепрыгнуть через стенку выгула, высота ее должна быть не менее - 2м для лаек. Нижняя часть сетки должна быть углублена не менее чем на 10-15 см в землю, чтобы собака не могла подкопаться и выйти из выгула. Для отдыха и укрытия собаки от ненастной погоды в середине выгула ставится деревянная будка, в которую кладется подстилка. При содержании в выгуле двух и более собак площадь выгула и ширина будки должны быть увеличены соответственно количеству собак. Площадь выгула очищается от травы, выравнивается и посыпается песком. Перед входом в будку кладется деревянный щит. В качестве подстилки используется сухая (не пыльная) пшеничная, ржаная, ячменная или овсяная солома. Солому можно заменить сухим древесным листом, заготовленным осенью. Помещение строится без пола и потолка. Посредине передней стены делается дверь, а над ней окно. В двери прорезывается отверстие (лаз) для собак. В помещении пол утрамбовывается и посыпается песком. Вдоль боковых стен, на высоте 0, 25 м от пола, устраиваются дощатые нары. Проход под нары зашивается досками. К помещению пристраивается выгул. Для сохранения чистоты помещения, будка и выгул ежедневно убираются. Подстилка для собак должна меняться не реже одного раза в неделю. В зимнее время на будке устраивают потолок и будка обкладывается сверху и с боков снегом или обивается соломенными матами, а вход в будку и лаз завешиваются матерчатыми занавесками.

Разведение охотничьих собак имеет цели: увеличение породного поголовья собак для удовлетворения растущего спроса со стороны охотников- 
любителей и охотников-промысловиков на породную охотничью собаку; улучшение и совершенствование существующих пород охотничьих собак как в экстерьерном отношении, так и по рабочим качествам и создание новых пород охотничьих собак, отвечающих требованиям охоты и условиям их выращивания и использования в различных районах РС (Я).

Основой успеха разведения охотничьих собак является правильно организованная и систематически проводимая племенная работа. Племенная работа, проводимая в охотничьем собаководстве, включает в себя три элемента:

1. Создание соответствующих условий кормления, содержания, ухода, дрессировки и тренировки взрослого поголовья охотничьих собак соответственно требованиям породы.

2. Систематическое проведение отбора и подбора, способствующего созданию, закреплению и дальнейшему развитию в породе желательных наследственных охотничьих свойств и породных признаков.

3. Направленное выращивание, воспитание и дрессировка молодняка соответственно требованиям его использования.

Отбором в охотничьем собаководстве называется выбор лучших кобелейпроизводителей и сук на племя для последующего их включения в план вязок. Отбор собак на племя основывается на всесторонней оценке их по экстерьеру и конституции, охотничьим качествам, происхождению и по потомству.

На полевых испытаниях оцениваются охотничьи (рабочие) качества собак. Оценка собак по происхождению устанавливается на основании их родословных (выписок из родословных книг). Оценка собак по потомству производится на основании оценок их потомков, полученных ими на выводках, выставках и полевых испытаниях.

На выставках, помимо оценки экстерьера и типа конституции охотничьих собак, проводится их бонитировка, т. е. комплексная оценка. В результате бонитировки определяется классность каждой охотничьей собаки. Для собак моложе трех лет установлено три класса: 1, 2 и 3-й, не требующие от них 
оценки по потомству. Для собак старше трех лет, помимо вышеуказанных классов, установлен класс «Элита», требующий от них обязательной оценки и по

потомству.

Для определения классности собак пользуются установленными нормативами, разработанными отдельно для каждой породы или группы пород охотничьих собак.

Для включения в план вязок отбирается преимущественно классное поголовье охотничьих собак. К кобелям-производителям, учитывая, что они дают потомство в несколько раз более многочисленное, чем суки, требования при отборе повышаются, в качестве производителей допускаются, в основном, кобели не ниже 2-го класса. В отношении сук требования при отборе могут быть несколько снижены в тех породах, которые не имеют достаточного количества классных сук ниже «хорошо».

Отобрав лучших собак, необходимо подобрать такие пары для вязки, сочетание которых может дать наилучшие результаты. В племенном охотничьем собаководстве применяется чистое разведение, т. е. такой метод, при котором вяжутся (спариваются) собаки, принадлежащие к одной породе. Высшей формой племенной работы при чистом разведении пород охотничьих собак является разведение по линиям. В каждой породе охотничьих собак необходимо установить отдельные группы собак - линии. Каждая линия имеет своего общего предка и сходство с ним в типе телосложения и характере работы. Выдающийся производитель, от которого ведет свое начало линия, называется родоначальником линии. Линия называется кличкой своего родоначальника. В понятие «разведение по линиям» входит подбор пар собак, относящихся к одной линии, а также и подбор пар собак разных линий, называемый межлинейным кроссом.

Основные требования подбора пар для вязки следующие. 1.Производитель, намечаемый для вязки, должен быть классом выше, чем сука. 2. Производитель не должен иметь недостатков в экстерьере и конституции, а также нежелательных свойств характера, общих с намечаемой ему для вязки 
сукой.

3. При подборе пар умеренно-родственное спаривание допускается как исключение и только в тех случаях, когда кобель и сука крепкого типа конституции и безупречного экстерьера.

4. При межлинейном кроссе к производителям подбираются суки тех линий, которые наиболее удачно сочетаются с линией производителя. 5. Производитель, давший хорошее потомство от какой-либо суки, снова вяжется с нею.

6. К производителю, впервые пускаемому в вязку, прикрепляют сук, которые дали хорошее потомство от его отца.

7. К производителям молодым подбираются суки более старшего возраста, и, наоборот, к старым производителям - молодые.

Период половой охоты суки называется пустовкой, или течкой. Пустовка, прежде всего, характеризуется изменением поведения суки. Она становится беспокойной, игривой и непослушной. У нее появляется влечение к кобелям, она часто и подолгу принюхивается к местам, где выгуливались собаки. При встрече с другими собаками она заигрывает с ними. Наружные половые органы ее набухают, наблюдается заметное их покраснение. Из половой шели появляется выделение, вначале с примесью крови, а затем слизистое. Продолжительность пустовки бывает различной: от двадцати одного до двадцати восьми дней. Пустовка у суки при нормальных условиях содержания бывает два раза в год, с промежутками между ними шесть-семь месяцев. Первая пустовка у сук бывает по достижении ими половой зрелости, которая чаще всего наступает в семи-девятимесячном возрасте.

Процесс спаривания кобеля с сукой называется вязкой. Во время вязки вследствие особого устройства половых органов кобеля и суки происходит склещивание, которое продолжается 15-45 мин. К вязкам допускаются собаки, достигшие полного физического развития, которое у сук наступает раньше, чем у кобелей. У собак мелких пород полное физическое развитие наступает раньше, чем у собак крупных пород. Нормальным возрастом собак для первой 
вязки следует считать: для лаек - для сук не моложе одного года шести месяцев и для кобелей — не моложе двух лет.

Вязки охотничьих собак допускаются только плановые. Сука к вязке допускается на 11-12-й день с начала пустовки. Вязка производится в выгуле или в помещении. Во время вязки кобель и сука должны быть на поводках. На злобную суку, чтобы не покусала кобеля, необходимо надеть намордник. После склещивания собак следует одну переднюю ногу кобеля перекинуть через спину суки, ошейники кобеля и суки сблизить на 40-50 см, связать их поводком и оставить до окончания склещивания. Через сутки производится повторная, так называемая контрольная, вязка.

Суке после вязки требуется улучшенное питание. Ей нужно давать молоко: в первый месяц 0,5 л, а начиная со второго месяца щенности и до конца щенения 1 л.

Период развития зародыша в матке суки называется щенностью. Щенность у сук обычно продолжается от шестидесяти до шестидесяти четырех суток, очень редко короче или длиннее этого срока. Щенность у суки становится заметной спустя пять недель после вязки. С этого времени у нее начинает заметно увеличиваться живот, также заметно изменяется и поведение: сука становится малоподвижной, избегает резких движений и прыжков. К концу щенности у суки набухают молочные соски, а перед щенением из них выделяется молозиво. Наружные половые органы также набухают, появляются выделения.

В период щенности сука должна кормиться три раза в сутки. Количество корма увеличивается, в корм добавляется молоко. Во второй половине щенности суки с ней прекращается охота. Чтобы щенение прошло легче, с сукой нужно проводить - ежедневные часовые прогулки. Водить собаку надо на поводке.

За неделю до щенения суке отводится более укромное место, на котором устанавливается большая лежанка типа ящика, со стенками 10- 15 см высотой. В лежанку кладется немного подстилки. За одни, а иногда двое суток до щенения сука отказывается от пищи и ест очень 
мало. Под влиянием родовых потуг появляется щенок, он выходит вместе с оболочками и как бы висит на пупочном канатике, который перегрызается сукой. После этого сука вылизывает щенка и освобождает его от родовой оболочки, которую поедает так же, как и послед, выходящий после родов. Беспокоить суку во время щенения не следует, нужно только наблюдать за ней. В случаях неправильного щенения, что бывает очень редко, необходимо обратиться за ветеринарной помощью.Сука приносит чаще от одного до десяти щенков, реже более десяти. Оставлять под сукой следует не более шестивосьми щенков в зависимости от ее физического состояния и молочности. Остальных щенков, если их крайне необходимо сохранить, подкладывают под другую суку-кормилицу. Кормилицей может быть сука любой породы, ощенившаяся одновременно или на два-три дня ранее или позднее той суки, щенки которой ей подкладываются. Подкладывание щенков под кормилицу производится на 2-4-й день после их рождения. Для этого у суки-кормилицы сдаивают несколько капель молока, которым смазываются подкладываемые щенки, после чего они укладываются со щенками кормилицы в ее отсутствии. Спустя 10-15 мин. сука-кормилица впускается к щенкам, и если она оближет подложенных щенков, и они возьмутся за соски, щенков можно оставить под кормилицей. При наличии у щенков прибылых пальцев они также должны быть обрезаны в это же время.

Во время лактации и до отъема щенков желательно давать молока больше. Прочие корма должны быть легко усваиваемыми организмом собаки. В частности, не следует давать щенкам и кормящим сукам каши, приготовленные из ячневой и перловой круп. Необходимо также, чтобы суки в это время получали достаточное количество витаминов. При кормлении пищей бедной витаминами нередко рождаются щенки, страдающие авитаминозами, в том числе и авитаминозом А, при котором у щенков замедляется рост, задерживается смена молодых резцов, отмечаются помутнение роговицы и расстройство функций желудочно-кишечного тракта, частые поносы.

C двух-трехнедельного возраста щенков необходимо прикармливать. 
Вначале, пока они не приучатся самостоятельно есть, их прикармливают теплым некипяченым молоком, налитым в блюдечко, затем жиденькой кашицей.

Прикармливать щенков до отъема их от матери следует три раза в день. Отъем щенков от матери производится на 30- 35-й день с момента их рождения.

Во время отъема сука уводится от щенков и к щенкам больше не подпускается. Отнятые от суки щенки кормятся шесть раз в сутки. Если у суки наблюдается обилие молока, отъем щенков можно производить и позднее тридцати-тридцати пяти дней с момента щенения, причем следует отнимать не всех щенков сразу, а постепенно.

Основная цель племенной работы с лайками - совершенствование их охотничьих свойств и породных качеств. Племенную работу организуют и ведут секции охотничьего собаководства при обществах охотников и рыболовов, питомники и охотничьи хозяйства, используя методы чистопородного разведения и руководствуясь стандартами пород, «Положением о племенной работе с породами охотничьих собак», а также оценками, полученными лайками на выставках и испытаниях. Поэтому при подборе пар необходимо внимательно изучать каждую собаку, выясняя наличие у нее ценных особенностей и нежелательных недостатков и в соответствии с этим рекомендуя подходящего производителя для спаривания.

Особое значение в племенной работе имеет использование кобелей, от которых можно получать значительно более многочисленное потомство, чем от сук. Чрезмерное увлечение одним, даже выдающимся, производителем, с нашей точки зрения, нецелесообразно, так как, во-первых, идеальных собак не бывает. Самая лучшая из них может оказаться носителем скрытых недостатков. Во-вторых, интенсивное использование выдающегося производителя резко ограничивает использование других, возможно, менее видных, но не менее ценных для породы.

В связи с этим при разведении лаек особенно тщательно нужно 
оформлять такие важные документы, как свидетельства о происхождении лайки. Небрежность и неточность в их заполнении снижают значение такого документа и затрудняют ведение племенного отбора и подбора.

У якутских лаек, которые относятся к аборигенам, сохранился преимущественно белково-жировой тип обмена веществ. Для них не пригодны нормы кормления, принятые в отечественном служебном собаководстве, которые рекомендуют восполнять энергетические затраты за счет углеводов, а не жиров.

В среднем одна собака съедает за сутки около 800 г мяса и жира. После тяжелой работы и в сильные холода корм варят с добавлением круп и муки, количество жира стараются увеличить.

Взрослую лайку кормят обычно 2 раза в день. В ежедневный рацион должны входить мясные продукты. Иногда их заменяют рыбой и молочными продуктами (творогом, простоквашей, молоком). Корм приготовляется в виде супа или негустой каши.

Собаки болеют многими болезнями, значительное число из них опасны для человека. Наиболее распространенными и опасными являются: бешенство, некоторые кожные заболевания, глистные болезни. Для собак опасна и чума плотоядных. В большинстве случаев легче предотвратить заболевание собаки, чем лечить ее. В нашей стране профилактические меры борьбы с болезнями собак регулярно осуществляются всеми ветеринарными лечебными учреждениями.

Особое внимание уделяется предупреждению бешенства - болезни, очень опасной не только для собак, но и для человека. Охотник должен регулярно делать своей собаке прививки против бешенства. Срок действия прививки 6 мес. Следует помнить, что провозить собаку на общественном транспорте запрещено, если нет справки о сделанной прививке против бешенства.

Собаки часто заражаются глистами, которые истощают их организм и бывают особенно опасны для щенков и молодняка. Кроме того, зараженная собака становится источником заражения человека этими паразитами. 
Особенно опасно и для собаки и для человека заражение ленточными глистами. Необходимо внимательно следить за собакой и регулярно, примерно через 6 мес, нужно проводить дегельминтизацию собак, т. е. выгонять глистов.

Кожные болезни - стригущий лишай, парша, зудневая чесотка, железница - также весьма опасны. Лечить собак от этих заболеваний очень трудно и часто собак, заболевших такими болезнями, приходится усыплять. Наиболее часто заболевают безнадзорные собаки, когда они рыщут везде, копаются на свалках, помойных ямах и т. п. Охотник должен правильно содержать лайку, чтобы она не заболела заразными кожными болезнями.

Для этого выгуливать ее надо лишь в местах, где нет разного рода свалок, стремиться предупреждать контактирование с бездомными собаками. Следует отметить, что чаще кожные болезни бывают незаразные. Это разного рода дерматиты, появляющиеся у собак в результате неправильного обмена веществ, недостатка витаминов, нервных потрясений. Однако во всех случаях появления кожных заболеваний собаку сразу же следует показать ветеринарному врачу.

Широко распространенное и очень опасное заболевание собак- чума плотоядных (кроме собак, ею болеют волки, лисицы, мелкие хищники, медведи и барсуки). Из всех пород охотничьих собак лайки наименее устойчивы к чуме и, заболев ею, многие погибают или, переболев, становятся непригодными для племенных целей. По нашим данным, из 100 родившихся щенков до 2-летнего возраста погибают около 70, если они не были привиты вакциной от чумы. Наиболее опасна чума для щенков. Заболев, они обычно погибают. Чтобы сохранить щенка, да и выросшую лайку, необходимо делать противочумные прививки. В нашей практике противочумную прививку мы делали щенкам в возрасте 2 мес уменьшенной дозой, по сравнению с дозой для взрослой собаки. Затем через 6-7 мес делали прививку дозой взрослой собаки.

У собаки, заболевшей чумой, шерсть становится тусклой, появляются гнойные истечения из носа и глаз, зловонный понос черного цвета. Собака отказывается от пищи, становится вялой, температура поднимается до 39-40 ${ }^{\circ} \mathrm{C}$. Важно заметить начальный период болезни, когда есть возможность спасти 
собаку. Для этого ее нужно поместить в теплое помещение, обеспечить покой и хорошее, легко усваиваемое питание. В течение 2-3 дней после обнаружения заболевания собаке нужно давать антибиотики (синтомицин, биомицин, пенициллин, норсульфазол) по одной таблетке 3 раза в день. Антибиотики лучше чередовать: например, сегодня дать биомицин, завтра пенициллин, затем синтомицин. Заболевшую собаку нужно держать в хороших условиях в течение месяца. В период временных улучшений, которые нередки и явно заметны, собаке нельзя давать никаких физических нагрузок: играть, бегать и тем более брать на охоту. Необходимо оберегать собаку от простуды. Обычно после интенсивной прогулки у кажущейся выздоровевшей собаки наступает резкое ухудшение и она, как правило, погибает. Лишь через месяц после начала заболевания можно приступить к постепенному восстановлению физической крепости собаки.

Одним из хороших признаков здоровья собаки служит ее шерстный покров. В связи с этим следует внимательно следить за состоянием шерсти лайки, особенно во время линьки, и содержать ее в порядке. Шерсть здоровой собаки должна быть не только чистой, но и блестящей. Тусклая шерсть указывает на то, что собака больна. Шерсть чистят гребнем и щеткой, протирают влажной тряпкой. Собаку с сильно загрязненной шерстью моют мылом в летнее время по необходимости, зимой не более 1 раза в 2-3 мес. Пока шерсть не просохнет, нельзя выпускать лайку в вольер в холодное время, чтобы она не простудилась. При возможности часто бывать в лесу, лайку в домашних условиях лучше вообще не мыть. Ее шерсть хорошо очищается от грязи, если охотник ходит с нею по высокой, мокрой от росы или дождя траве, а также по глубокому снегу.

Предельная продолжительность жизни собак, по сообщениям ряда авторов достигает 16-22 лет. Лайки живут значительно меньше. Нам известно очень немного случаев, когда они доживали до 15-16,5 лет. В большинстве случаев умирают они значительно раньше.

Лайка обычно может достаточно хорошо работать до 10, редко до $11-12$ 
лет. (Власов Н.Н., Камерницкий А.В., Медведева И.М.,1992; Войлочников А.Т., Войлочникова С.Д., 1974; Мазовер А.П., 1979; Псалмов М.Г., 1990).

\section{4. Натаскивание и оценка охотничьих собак.}

Для оценки рабочих качеств лаек проводятся различные испытания. С учетом разнообразного применения лаек на промысле и в спортивной охоте их испытывают по многим видам зверей и птиц. Для каждого вида испытаний существуют отдельные правила. Собак испытывают в охотничьих угодьях по диким животным, находящимся в условиях естественной свободы, т. е. условиях, максимально приближенных к охотничьей обстановке. Исключения допускаются лишь на испытаниях по медведю, когда работу лаек проверяют по подсадному (находящемуся на цепи) зверю.

Работу собак оценивают специально назначенные комиссии, состоящие обычно из трех человек, среди которых по меньшей мере один должен быть квалифицированным экспертом. На испытаниях присуждаются дипломы I, II и III степеней. При этом испытываемая собака должна набрать не только определенную сумму баллов за все регистрируемые показатели работы, но и установленный минимум баллов за основные качества, определяющие успех охоты.

Испытания лаек по белке. Работа лайки по этому виду (а также по соболю, глухарю, тетереву) расценивается по следующей шкале максимальных баллов:

$\begin{array}{llll}\text { Чутье (обоняние, слух, зрение) } & 30 & \text { Слежка } & 15 \\ \text { Быстрота поиска } & 10 & \text { Вязкость } & 10 \\ \text { Правильность поиска } & 10 & \text { Послушание } & 5 \\ \text { Голос } & 5 & \text { Отношение к убитому зверю } & 5 \\ \text { Характер облаивания } & 10 & \text { Общий балл } & 100\end{array}$

Дипломы за охотничьи качества присуждаются при получении следующих минимальных оценок: 


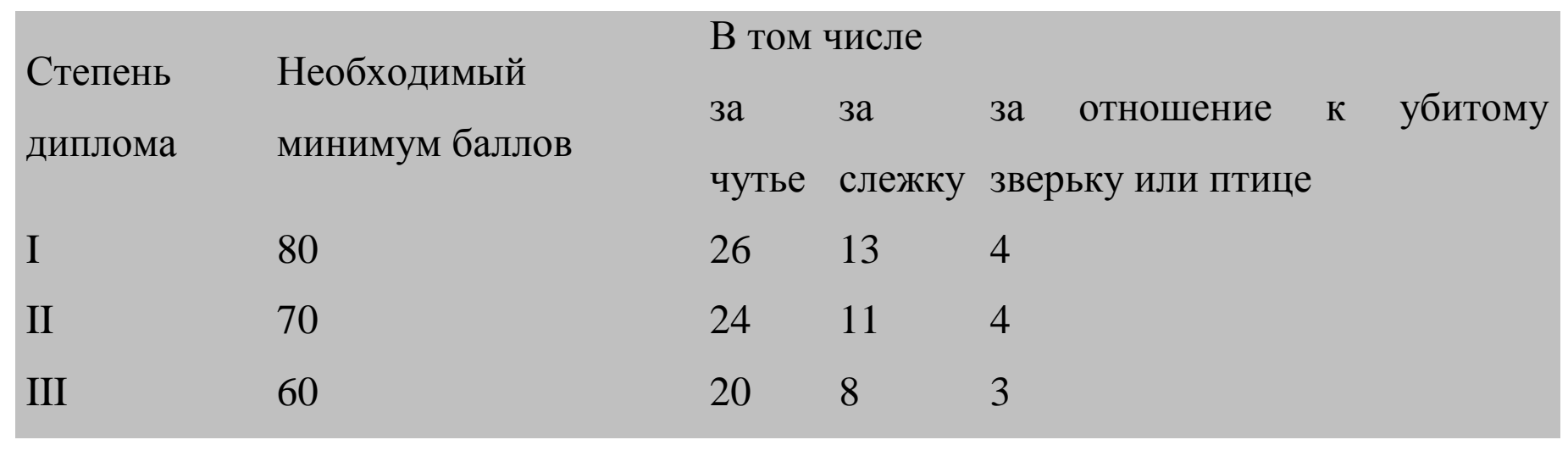

Для присуждения диплома лайка должна найти не менее двух белок или птиц (кроме глухаря) и показать по ним работу. Собака, работавшая только по одной белке, тетереву или фазану, оценивается, но диплом ей не присуждается. При испытаниях по кунице, соболю или глухарю для присуждения диплома достаточно одной работы.

На поиск зверьков или птиц испытываемой лайке дается 60 мин. Время, затрачиваемое ей на облаивание найденного зверька (а также на пустое облаивание), слежку и на проверку отношения собаки к убитому зверьку, не учитывается. Время для поиска обычно разделяется на два напуска по 30 мин, если испытывается несколько собак. Предоставление добавочного времени на поиск (сверх положенных 60 мин) не допускается.

Для получения диплома I степени лайка должна найти не менее четырех зверьков и показать при этом хорошую работу. Если она при этом допустит одно пустое облаивание (Пустой полайкой считается та, если белка не обнаружена в радиусе 25 м от дерева, на которое лаяла собака. Белка, обнаруженная в радиусе $15-25$ м от места облаивания, не засчитывается, но полайка пустой не считается.), то диплом I степени не присуждается (экспертной комиссии предоставляется право присудить диплом I степени с баллом за чутье не выше 26 , если собака сделала одну пустую полайку, но в течение 60 мин нашла не менее семи белок). Для присуждения диплома II степени ей нужно показать хорошую работу по трем белкам, а диплома III степени - по двум. Диплом II степени не присуждается, если лайка сделала две, а диплом III степени - три пустые полайки. Собака может быть испытана 
как по двум зверькам или двум птицам одного вида, так и по двум зверькам разных видов или одному зверьку и одной птице, указанным в данных правилах. В дипломе отмечается, по каким зверькам или птицам работала собака.

В процессе испытаний особое внимание уделяется слежке. При отсутствии слежки работа собаки расценивается, но диплом ей не присуждается.

Во время испытаний отстреливают за день не более двух зверьков или птиц. По ним проверяют отношение к убитому животному всех собак, проходящих испытания. Тушку убитого животного подбрасывают в момент выстрела в крону дерева и наблюдают за тем, как ведет себя собака, подбежав к месту падения тушки. Собака, утаскивающая, жующая, рвущая и пожирающая добытого зверька или птицу, в соответствии с правилами испытаний оценивается, но диплом ей не присуждается.

Существующие правила испытаний лаек разработаны опытным путем и проверены многолетней практикой. Они позволяют выявлять собак с хорошими рабочими качествами, что необходимо, для ведения племенной работы. Однако, на наш взгляд, эти правила все же не совершенны. Это касается в первую очередь требований получения необходимого минимума баллов за слежку и отношение к убитому зверьку, чтобы лайка получила диплом той или иной степени. Оба эти элемента работы отражают прежде всего опыт собаки, т. е. не ее врожденные свойства, а приобретенные в процессе обучения и тренировки. Основное же внимание в селекционно-племенной работе должно быть обращено на выявление, отбор и закрепление ценных врожденных охотничьих свойств лаек.

Молодые лайки, обладающие большой охотничьей страстью, вязкостью и отличным чутьем, быстро находящие дичь и точно указывающие ее месторасположение, нередко очень плохо следят зверька, идущего верхом, а иногда и не умеют следить его. Однако, как показывает практика, с такими собаками можно охотиться достаточно успешно. Исключение таких лаек из 
селекционной работы нежелательно. Следовало бы изменить требования, предъявляемые к слежке собаки. Например, диплом III степени (с оценкой от 1 до 5 баллов) присуждать собакам, быстро и точно находящим белок, но не следящих или плохо следящих идущего верхом зверька. Диплом II степени присуждать лайкам, показывающим удовлетворительную или почти хорошую слежку (с оценкой работы б-10 баллов), диплом I степени - с хорошей и отличной слежкой (оценка $11-15$ баллов).

Отношение к убитому зверьку — элемент работы, также показывающий преимущественно дисциплину собаки, ее воспитание и обучение. В прежние правила испытаний этот элемент не включался. Следовало бы его также исключить из расценочной таблицы, так как оценка отношения собаки к убитому животному по давно отстрелянному, стылому и подбрасываемому под выстрел зверьку не выдерживает никакой критики. К такому зверьку лайка подходит только ради интереса и не проявляет тех свойств, которые наблюдаются, когда облаиваемое животное действительно отстреляно и упало на землю. Есть и другая сторона вопроса. Как мы упомянули, ежегодно тысячи лаек испытываются по белке. Если для каждого дня испытаний отстреливать по одной-две белки, особенно в весенне-летний период, когда идет размножение зверьков, это приносит большой ущерб поголовью ценного промыслового вида. Ведь под выстрел попадают нередко беременные и кормящие самки. Наконец, как показал опыт, некоторые эксперты игнорируют этот пункт правил и не отстреливают белок для проверки у испытываемых лаек отношения к убитому зверьку. В этой графе расценочной таблицы эксперт ставит обычно положительный балл, ориентируясь на то, насколько собака послушна. Лайки, получившие при этом дипломы, в дальнейшем успешно выступали на крупных состязаниях и были «вежливы» на промысле белки.

Испытания лаек по норке, хорю, колонку и горностаю. Лаек по этим видам испытывают редко, обычно при нахождении этих зверьков собакой во время проведения других испытаний. На испытаниях по этим мелким представителям семейства куньих работа лайки расценивается по приводимой 
ниже шкале максимальных баллов:

Чутье (обоняние, слух и зрение) 30

Вязкость........... 10

Быстрота поиска ....... 5

Злоба и приемистость .... 15

Правильность поиска..... 10 .

Послушание .......... 10

Голос и облаивание ..... 5

Слежка ........... 15

Общий балл .......... 100

Дипломы за работу по этим зверькам присуждаются при получении следующих минимальных оценок:

Степень диплома

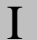

II

III
Общий балл

80

70

60

\section{В том числе}

за чутье за слежку

за злобу и приемистость

24

12

12

22

10

10

20

8

8

Собака испытывается по одному зверьку, для нахождения которого ей предоставляется 60 мин. Для присуждения диплома обязательны поимка собакой зверька или его отстрел. Особое внимание на этих испытаниях обращается на способность собаки быстро находить зверька, следить за ним во время перемещений под валежинами или по зарослям кустарников, а также на ее умение своевременно и бесстрашно схватить настигнутого и ожесточенно сопротивляющегося хищника и не выпускать его, даже если он вцепится зубами за чувствительное место (за мочку носа, губы).

Испытания лаек по лосю и оленю. Такие испытания чаще всего происходят при встрече собак с этими животными во время проведения других испытаний. Такие встречи, если у лайки есть задатки работы по копытным, в 
наше время нередки, так как численность лосей во многих районах европейской части СССР высокая. Работа лайки по лосю и оленю расценивается по приводимой ниже шкале максимальных оценок.

\begin{tabular}{lrlc} 
Чутье (обоняние, слух & \multicolumn{1}{c}{ и } \\
зрение) & 20 & Вязкость & 15 \\
Быстрота поиска & 10 & Голос & 10 \\
Правильность поиска & 10 & Послушание & 5 \\
Мастерство постановки & и & & 100
\end{tabular}

Дипломы за работу по лосю и оленю присуждаются при получении собакой следующих минимальных оценок

$\begin{array}{lccc}\text { Степень диплома } & \text { Общий балл } & \text { В том числе } & \\ \text { I } & & \text { за чутье } & \text { за мастерство } \\ \text { II } & 70 & 16 & 24 \\ \text { III } & 60 & 14 & 22 \\ \end{array}$

Оценка производится за работу по одному зверю, на поиск которого собаке дается 2 ч.

Важнейший элемент работы по лосю - мастерство постановки, т. е. умение лайки, разыскав зверя, заставить его не уходить с того места, где собака начала облаивать его или, если он пошел, остановить через некоторое время и, задержав здесь, вновь начать облаивание. Лайка снимается с испытаний, если она без посторонних помех не смогла задержать зверя при его остановках до 3 раз, а также если она отдает голос по следу преследуемого животного.

Испытания лаек по подсадному медведю. Для проведения таких испытаний в лесу выбирается поляна, где между деревьями, отстоящими друг от друга на 40-50 м, на высоте 10-12 м натягивают прочный трос. На трос 
надевают кольцо или блок с присоединенной к ним цепью длиной не менее 20 м. Другим концом цепь прикрепляют к ошейнику, надетому на медведя. Медведь должен быть весом не менее 80 кг.

К испытаниям по подсадному медведю допускаются как одиночные собаки, так и пары. Владельцам не разрешается натравливать на медведя своих собак.

Работа лаек по медведю расценивается по шкале максимальных баллов.

\begin{tabular}{|c|c|c|c|}
\hline $\begin{array}{l}\text { Отношение к следу и } \\
\text { зверю }\end{array}$ & 15 & Ловкость & 15 \\
\hline $\begin{array}{l}\text { Смелость } \\
\text { облаивание }\end{array}$ & 25 & Вязкость & 20 \\
\hline $\begin{array}{l}\text { Злобность } \\
\text { приемистость хваток }\end{array}$ & 25 & Общий балл & 100 \\
\hline
\end{tabular}

Для присуждения той или иной степени диплома собака должна получить за основные показатели работы следующие минимальные оценки в баллах:

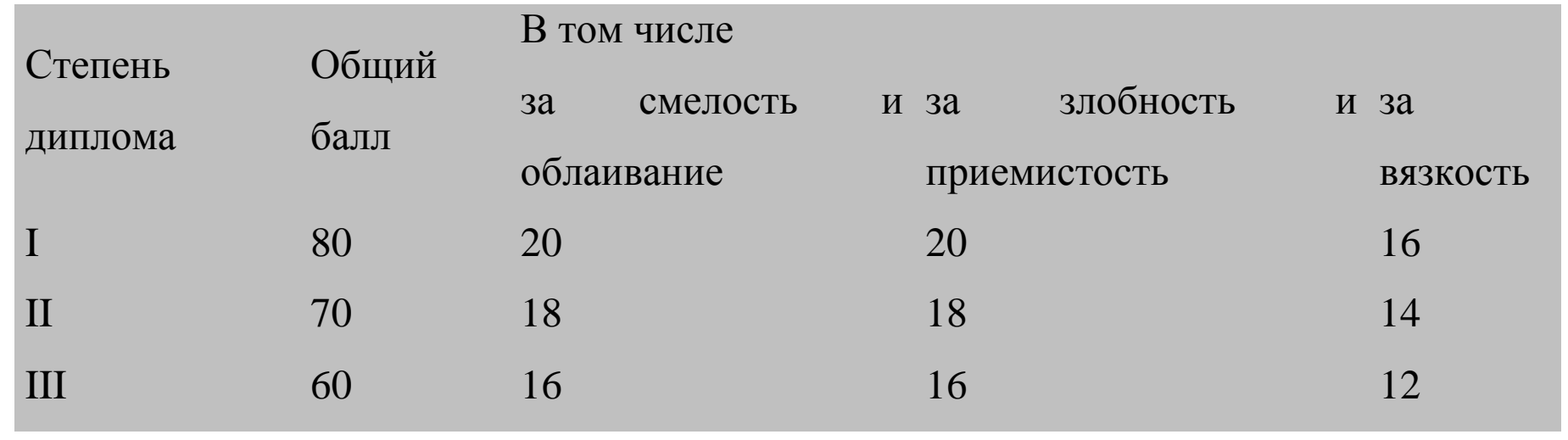

Чтобы получить диплом, собака должна смело атаковать медведя и во время атак при удобных моментах делать сильные болевые хватки по уязвимому месту (за «гачи», или за тыльные стороны ног). Лайки, не делающие хваток, но набравшие за отношение к следу и зверю не менее 12 баллов, за смелость и облаивание не менее 16 баллов, за вязкость не менее 14 баллов, при общей сумме баллов не менее 60 могут быть дипломированы, но не выше 
диплома III степени, как берложницы. Диплом присуждается собаке только за работу в одиночку. В работе парой, если одна из лаек не делает хваток по зверю, диплом выше III степени не присуждается.

Испытания лаек по водоплавающей птице. Такие испытания по количеству участвующих в них лаек, по-видимому, находятся на втором месте после испытаний по белке. Эти испытания лучше проводить по диким уткам, наиболее распространенному объекту охоты. На испытаниях не разрешается использовать подсадных уток. Элементы работы лайки оцениваются такими максимальными баллами:

Чутье (обоняние, слух, зрение) $\quad 25$; Поиск 10 ; Подача отстрелянной или раненой птицы 25 ; Настойчивость в работе 15 ; Послушание 10 ; Слежка $15 ;$ Общий балл 100

Дипломы за охотничьи качества присуждаются при следующих показателях:

$\begin{array}{lccl}\text { Степень диплома } & \text { Общий балл } & \text { В том числе } \\ \text { I } & 80 & \text { за чутье } & \text { за подачу птицы } \\ \text { II } & 70 & 20 & 20 \\ \text { III } & 60 & 18 & 18\end{array}$

Работа каждой собаки оценивается по двум встречам с птицей, на поиск которых дается 60 мин.

Испытания обычно проводят с отстрелом за день одной- двух птиц для оценки подачи. Для лаек, из-под которых не отстреливали дичь, проверку подачи производят, подбрасывая под выстрел дичь в водоем.

Испытания лаек организуются в основном с целью выявления у них охотничьих качеств, но в какой-то мере они являются и своеобразной формой 
спортивного соревнования владельцев собак, стремящихся показать, насколько хороши их питомцы в работе. Поэтому естественны радость и гордость одних, собакам которых присуждают дипломы высоких степеней, и горечь других, чьи лайки «провалились» на испытаниях.

Не следует думать, что каждая лайка, проявившая свои охотничьи качества не только во время натаски, но уже и зарекомендовавшая себя хорошей работницей, должна обязательно получить диплом, на испытаниях. Практика испытаний и особенно состязаний свидетельствует о другом значительное число неоднократно проверенных в работе и дипломированных собак не получают дипломы.

На результативность и качество работы лаек действуют многие факторы: состояние здоровья, тренированность, особенности характера, настроение собаки, окружающая обстановка и т. п.

К испытаниям собаку нужно всегда подготавливать и выставлять ее в лучшей форме. Не только ожиревшая из-за долгого сидения дома, но и перетренированная, затасканная на охоте лайка не покажет полностью свои лучшие качества. Тренировки желательно начинать задолго до испытаний, а перед ними дать собаке 3...5-дневный отдых, чтобы она работала охотно. В день испытаний, рано утром, собаку кормить нужно не много, но калорийной пищей и дать ей возможность хорошо выгуляться.

На испытаниях, в ожидании своей очереди, не следует водить собаку за экспертной комиссией. Лайка, особенно темпераментная, слыша лай работающих участниц, волнуется, нервничает, рвется с поводка. Перевозбужденная, она может делать пустые полайки и не покажет свойственной ей работы. Лучше, договорившись с экспертами, ожидать своей очереди у костра.

Получив указание пускать собаку в поиск, не нужно торопиться и делать это рядом с экспертной комиссией. Перед тем как снять с лайки ошейник, лучше отойти в сторону, успокоить ее и взять направление, где имеется возможность больше встретить зверьков или птицы. Проходить по угодьям, где 
может держаться дичь, надо не торопясь, «челноком», давая возможность собаке лучше обыскать такие места. При проверочных или неуверенных полайках нежелательно быстро подходить к собаке. Лучше остановиться несколько в стороне и, наблюдая за ней, дать возможность самой разобраться в следах, увидеть зверька или птицу. Владельцу также следует избегать любых действий, которые могут отвлечь внимание собаки от поиска и обнаружения дичи. (Власов Н.Н., Камерницкий А.В., Медведева И.М.,1992; Войлочников А.Т., Войлочникова С.Д., 1974; Мазовер А.П., 1979; Псалмов М.Г., 1990).

\section{Выводы}

1.Стимуляция биологически активными веществами не позволяет полностью компенсировать недоразвитие мелких щенят лисиц. Частичная компенсация недоразвития щенят лисиц была получена при введении им в корм 40,0 мг янтарной кислоты на 1 кг живой массы на 40-й день их жизни.

2.Результаты двухфакторного дисперсионного анализа подтвердили, что наибольшее стимулирующее влияние на гипотрофичных щенят лисиц оказали биологически активные вещества в следующих дозах - парааминобензойная кислота - 1,0 мг на 1 кг живой массы; сукцинат хитозана - 1,0 мг на 1 кг живой массы; янтарная кислота - 40 мг на 1 кг живой массы и цеолит 5,0 г на 1 голову молодняка.

3.К 4-месячному возрасту, щенята лисиц, получавшие парааминобензойную кислоту имели живую массу 3,83-3,84 кг; сукцинат хитозана 3,69-3,72 кг; янтарную кислоту - 3,95-4,09 кг и цеолит - 3,78-3,79 кг. Тогда как щенки контрольной группы в этом возрасте достигли живой массы 3,47-3,50 кг. Анализ результатов исследования свидетельствует о том, что биологически активные вещества положительно повлияли на длину тела и обхват груди опытных щенят-гипотрофиков.

4. Наибольшее количество слабо развитых щенят отошло к 4-месячному возрасту, среди особей контрольной группы - 52,18 \%, тогда как в опытной группе, получавшей парааминобензойную кислоту - 34,79 \%. Таким образом, 
введение микродоз биологически активных веществ повышает сохранность щенят на 6,34-17,39\%.

5.Отход щенят опытных групп к 4-месячному возрасту был меньшим по сравнению с контрольной группой на 3,55-8,10\%. Сохранность щенят к концу эксперимента составила в опытных группах 54,16-65,21\%, что больше чем в контроле, где сохранность составила 47,82\%.

6. Морфологические показатели крови молодых лисиц свидетельствуют о том, что дача парааминобензойной кислоты, сукцинат хитозана, янтарной кислоты и цеолита в корм не вызывают глубоких изменений в ее составе. Количество эритроцитов, лейкоцитов и процент гемоглобина у этих зверей во всех группах находились в пределах физиологической нормы. Введение биологически активных веществ повышает у них содержание общего белка и гамма-глобулиновой фракции, особенно у особей получавших ПАБК и ЯК.

7.Изучение внутренних органов показало, что дача парааминобензойной кислоты, сукцината хитозана, янтарной кислоты и цеолита в корм зверей существенно не повлияло на внутренние органы.

8. Гистологические исследования печени, почек и селезенки показали, что в их клетках не было патологических изменений. В лимфатических фолликулах селезенки у лисиц опытных групп, по сравнению с контрольной, наблюдалось различное количество клеточных центров размножения. У лисиц контрольной группы в лимфатических фолликулах селезенки наблюдалось обеднение лимфатических фолликулов с невыраженными реактивными центрами.

9. При бонитировке контрольных и опытных лисиц было установлено, что введение в корм зверей парааминобензойной кислоты, сукцинат хитозана, янтарной кислоты и цеолита улучшало такие показатели как размер и телосложение у самцов и самок, и не оказывало отрицательного влияния на качество и окрас волосяного покрова.

Результаты бонитировки лисиц подтверждаются и товароведческой оценкой их шкурковой продукции. 
10. Использование в рационах гипотрофичного молодняка лисиц оптимальных доз биологически активных веществ с целью повышения эффективности производства шкурковой продукции экономически выгодно: экономический эффект в расчете на одну шкурку лисицы составил 72,00 руб. при даче 1,0 мг парааминобензойной кислоты; 59,00 руб. - при даче 1,0 мг сукцината хитозана; 83,00 руб. - при даче 40,0 мг янтарной кислоты; 79,00 руб. - при даче 5,0 г цеолита на голову.

11 . Разведение стандартной норки в 60-е годы XX века и в 2005-2006 г. доказывает о широкой возможности разведения норок в условиях Центральной Якутии.

12. В Республике Саха (Якутия) есть все предпосылки для возрождения якутской лайки, как аборигенного представителя охотничьих собак.

\section{ЛИ Т Е Р А Т У Р А}

1. Балакирев Н.А. Кормление норок. М.: Россельхозакадемия, 1997.249c.

2. Балакирев Н.А., Кузнецов Г.А. Звероводство. - М.: КолосС, 2006.-343c.

3. Берестов В.А. Звероводство. - СПб.: Лань, 2002. - $128 \mathrm{c}$.

4. Веселов В.И., Заболоцкий И.П. Двухлетний опыт разведения норок в Центральной Якутии. Якутск, 1964 - 59 с.

5. Ильина Е.Д., Соболев А.Д. Звероводство. - М.: Агропромиздат, 1990. $-267 \mathrm{c}$.

6. Никанорова М. И., Дьячковский М. И., Черкашина А.Г. и др. План селекционно-племенной работы в клеточном звероводстве РС (Я) до 2010 года. - Якутск, 2004.-63c.

7.Перельдик Н. Ш. , Милованов Л. В. , Ерин А.Т. Кормление пушных зверей - М.: Агропромиздат, 1987 - 351с.

8.Сельское хозяйство Республики Саха (Якутия): Учебное пособие/ Коллектив авт.: А. Ф. Абрамов, Н. Д. Алексеев, Д. Е. Афанасьев и др.; М-во сел. хоз-ва Рос.Федерации, Якут. ГСХА - Якутск: Бичик, 2001. - 432с. 